ALEXANDRE BELLEGARD FARINA

AVALIAÇÃO DA SEQÜÊNCIA DE TRANSFORMAÇÕES DE FASES DO AÇO AISI 430 CONVENCIONAL

São Paulo

2010 
ALEXANDRE BELLEGARD FARINA

\title{
AVALIAÇÃO DA SEQÜÊNCIA DE TRANSFORMAÇÕES DE FASES DO AÇO AISI 430 CONVENCIONAL
}

\author{
Dissertação apresentada à Escola \\ Politécnica da Universidade de São \\ Paulo para obtenção do título de \\ Mestre em Engenharia \\ ÁREA DE CONCENTRAÇÃO: \\ ENGENHARIA METALÚRGICA \\ E DE MATERIAIS
}

Orientador: Prof. Titular

Hélio Goldenstein

São Paulo

2010 
ALEXANDRE BELLEGARD FARINA

AVALIAÇÃO DA SEQÜÊNCIA DE TRANSFORMAÇÕES DE FASES DO AÇO AISI 430 CONVENCIONAL

Dissertação apresentada à Escola Politécnica da Universidade de São Paulo para obtenção do título de Mestre em Engenharia

São Paulo

2010 
Este exemplar foi revisado e alterado em relação à edição original, sob responsabilidade única do autor com a anuência de seu orientador.

São Paulo, 09 de março de 2010

Assinatura do autor:

Assinatura do orientador:

FICHA CATALOGRÁFICA

Farina, Alexandre Bellegard

Avaliação da seqüência de transformações de fases do aço AISI 430 convencional. / A.B. Farina. - ed.rev. - São Paulo, 2010.

$107 \mathrm{p}$.

Dissertação (Mestrado) - Escola Politécnica da Universidade de São Paulo. Departamento de Engenharia Metalúrgica e de Materiais.

1. AISI 430 2. ThermoCalc 3. Análise Rietveld 4. Metalurgia Física 5. Transformações de fases I.Universidade de São Paulo. Escola Politécnica. Departamento de Engenharia Metalúrgica e de Materiais II.t. 
Dedico este texto aos meus pais Marcos (in memoriam) e Cristina, aos meus irmãos (Guilherme e Ricardo), à minha avó (Helena) e à minha esposa (Paula). 


\section{AGRADECIMENTOS}

Ao meu orientador e sobretudo amigo Prof. Dr. Hélio Goldenstein pela imensa ajuda, apoio e confiança durante estes vários anos de trabalhos em conjunto sob os mais variados e interessantes temas.

Aos professores Dr. Flávio Beneduce Neto, Dr. André Luis Vasconcelos da Costa e Silva e Dr. Roberto Ribeiro de Avillez pelo apoio e pelas valiosas discussões sobre modelagem termodinâmica.

Aos colegas, professores e amigos do Departamento de Engenharia Metalúrgica da EPUSP pelo apoio durante o desenvolvimento das atividades deste projeto.

A ArcellorMittal Inox Brasil, pelo financiamento deste projeto e pela bolsa de estágio de graduação concedida. Ao Dr. Tarcisio Reis de Oliveira pelo apoio e pelas valiosas discussões e sugestões durante o desenvolvimento deste projeto. Aos colegas do centro de pesquisas da ArcellorMittal Inox Brasil pelo apoio na execução deste projeto.

Ao Prof. Dr. Marcos Flávio Campos pela grande colaboração em diversos projetos realizados que trouxeram grandes contribuições a este e a outros trabalhos.

A minha esposa, Paula Fernanda da Silva Farina, pela sua sempre agradável companhia e grande ajuda na revisão e formatação deste texto.

Aos meus pais Marcos (in memoriam) e Cristina e irmãos (Ricardo e Guilherme) pela grande paciência e ajuda nos momentos mais necessários. 
"O único lugar onde o sucesso vem antes do trabalho é no dicionário" Albert Einstein 


\section{RESUMO}

Este trabalho visa caracterizar a seqüência de precipitação do aço inoxidável ferrítico do tipo AISI 430 convencional, durante a etapa de laminação a quente. Esta caracterização foi realizada através do estudo de três condições industriais e de seis condições tratadas termicamente. Todas as amostras foram avaliadas por microscopia ótica e eletrônica de varredura, extração de precipitados e difração de raios-X do material como um todo e dos precipitados extraídos. Foi realizada a modelagem termodinâmica do aço utilizando-se o programa ThermoCalc ${ }^{\circledR} \mathrm{v}$.R aliado ao banco de dados TCFE2. Como meio de prever a cinética das transformações de fases, de modo superficial, foi realizado um ensaio de análise térmica diferencial com três taxas de resfriamento com redução progressiva (10\%min, 5\%min e $2 \% \mathrm{~min}$ ), sendo os resultados comparados com os resultados experimentais obtidos pelas demais técnicas empregadas.

O aço AISI 430 convencional mostrou-se bifásico a alta temperatura, apresentando o campo bifásico (ferrita/austenita) entre $900^{\circ} \mathrm{C}$ e $1250^{\circ} \mathrm{C}$. Após tratamentos térmicos por $5 \mathrm{~h}$ nas temperaturas de $900^{\circ} \mathrm{C}, 1000^{\circ} \mathrm{C}$ e $1100^{\circ} \mathrm{C}$, seguido de têmpera em água e partindo-se da condição laminado a quente e recozido (BQB), o aço apresentou microestrutura dúplex (ferrita/martensita). As amostras tratadas a $900^{\circ} \mathrm{C}$ e $1000^{\circ} \mathrm{C}$ apresentaram pequenas frações residu ais de carbonetos do tipo $\mathrm{M}_{23} \mathrm{C}_{6}$. As amostras tratadas a $600^{\circ} \mathrm{C}, 700^{\circ} \mathrm{C}$, e $800^{\circ} \mathrm{C}$ por $5 \mathrm{~h}$ e temperadas em água mostraram-se ferríticas com presença de carboneto do tipo $\mathrm{M}_{23} \mathrm{C}_{6}$ com teores de carboneto decrescentes com o aumento da temperatura do tratamento térmico. As amostras da condição industrial e as amostras tratadas a $600^{\circ} \mathrm{C}, 700^{\circ} \mathrm{C}, 800^{\circ} \mathrm{C}$ e a $900{ }^{\circ} \mathrm{C}$ apresentaram a presença de nitretos do tipo $(\mathrm{Cr}, \mathrm{Fe})_{2} \mathrm{~N}$, sendo que a amostra tratada a $900{ }^{\circ} \mathrm{C}$ apresentou apenas resíduos deste ni treto, em pleno acordo com a termodinâmica computacional que prevê decomposição deste na temperatura de ${ }^{866} \mathrm{C}$, indicando que a cinética de decomposição deste nitreto é lenta. A temperatura de precipitação do carboneto do tipo $\mathrm{M}_{23} \mathrm{C}_{6}$ rico em $(\mathrm{Cr}, \mathrm{Fe})_{23} \mathrm{C}_{6}$ foi avaliada entre $900^{\circ} \mathrm{C}$ e $1000^{\circ} \mathrm{C}$. 


\begin{abstract}
This work aims to characterize the precipitation path of the conventional ferritic stainless steel AISI 430, during the hot rolling process. This characterization had been carried out with the study of three industrial conditions, and six thermal treated conditions. All the samples were evaluated by optical and scanning electron microscopy, by extraction of precipitates and X-Ray diffraction of the bulk material and of the extracted precipitates. It was done a thermodynamic modeling of the steel with the use of the ThermoCalc ${ }^{\circledR}$ v.R program and TCFE2 data base. In a way to determine the phase transformations kinetics, in a superficial way, it was carried out differential thermal analysis with three cooling rates progressively reduced $(10 \% \mathrm{~min}$, $5 \%$ min e $2 \% \mathrm{~min}$ ), all the results were compared wit $\mathrm{h}$ the experimental results got with the others techniques employed.

The conventional AISI 430 steel is two-phase at high temperatures, showing a two-phase field (ferrite/austenite) between $900^{\circ} \mathrm{C}$ and $1250^{\circ} \mathrm{C}$. After the thermal treatments for $5 \mathrm{~h}$, steel in the hot rolled and annealed (BQB) initial condition, at $900^{\circ} \mathrm{C}, 1000^{\circ} \mathrm{C}$ and $1100^{\circ} \mathrm{C}$, followed by water quench, the steel showed a duplex microstructure (ferrite/martensite). The samples heat treated at $900^{\circ} \mathrm{C}$ and $1000^{\circ} \mathrm{C}$ showed a residual volumetric fraction of the $\mathrm{M}_{23} \mathrm{C}_{6}$ carbide. The samples heat treated for $5 \mathrm{~h}$ at $600^{\circ} \mathrm{C}, 700^{\circ} \mathrm{C}$ and $800^{\circ} \mathrm{C}$ and water quenched showed a ferritic microstructure with the presence of $\mathrm{M}_{23} \mathrm{C}_{6}$ carbide, with its content decreasing with the heat treatment temperature increase. The samples in the industrial condition and the samples heat treated at $600^{\circ} \mathrm{C}, 700^{\circ} \mathrm{C}, 800^{\circ} \mathrm{C}$ and at $900^{\circ} \mathrm{C}$ showed a $(\mathrm{Cr}, \mathrm{Fe}){ }_{2} \mathrm{~N}$ nitrite presence, the sample heat treated at $900^{\circ} \mathrm{C}$ showed only a residual volumetric fraction of it. This is in great deal with the computational thermodynamic modeling that predicts nitride decomposition at $8^{\circ} 6^{\circ} \mathrm{C}$, indic ating that the nitrite decomposition kinetic is slow. The precipitation temperature of the $\mathrm{M}_{23} \mathrm{C}_{6}$ carbide rich in $(\mathrm{Cr}, \mathrm{Fe})_{23} \mathrm{C}_{6}$ was evaluated between $900^{\circ} \mathrm{C}$ and $1000^{\circ} \mathrm{C}$.
\end{abstract}




\section{$\underline{\text { ÍNDICE }}$}

Lista de Figuras

Pág. xi

Lista de Tabelas

Pág. xix

1.0 Introdução.

Pág. 001

2.0 Revisão Bibliográfica.

Pág. 002

2.1 Efeito dos elementos de liga nos aços inoxidáveis ferríticos. Pág. 004

2.2 Microestrutura dos aços inoxidáveis ferríticos. Pág. 009

2.3 Extração de precipitados. Pág. 011

2.4 Difração de raios- $X$. Pág. 013

2.4.1 Análise de Rietveld. Pág. 017

2.5 Análise térmica diferencial. Pág. 018

2.6 Modelagem das transformações de fases. Pág. 023

2.6.1 Aplicações aos aços inoxidáveis ferríticos Pág. 027

2.7 Recristalização e crescimento de grão. Pág. 029

2.7.1 Aplicações aos aços inoxidáveis ferríticos Pág. 033

3.0 Objetivos.

Pág. 037

4.0 Materiais e Métodos. Pág. 038

4.1 Caracterização metalográfica Pág. 038

4.2 Extração de precipitados Pág. 040

4.3 Modelagem termodinâmica. Pág. 041

4.4 Difração de raios $X$ Pág. 042

4.5 Tratamentos térmicos. Pág. 043

4.6 Análise térmica diferencial (DTA) Pág. 044

5.0 Resultados Pág. 046

5.1 Modelagem Termodinâmica. Pág. 046

5.2 Difração de raios- $X$. Pág. 048

5.2.1 Difração da matriz. Pág. 049

5.2.2 Difração dos precipitados extraídos Pág. 052 


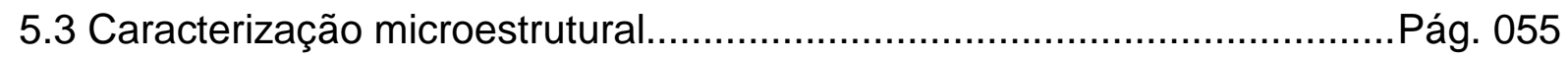

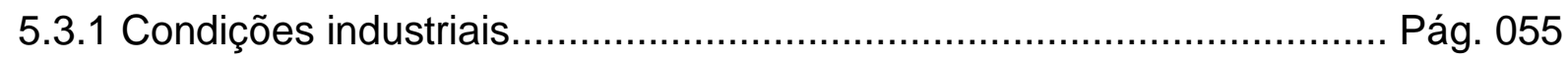

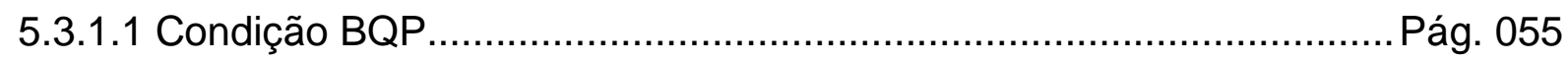

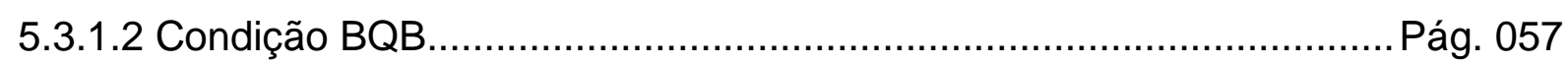

5.3.1.3 Condição BFB......................................................................... Pág. 059

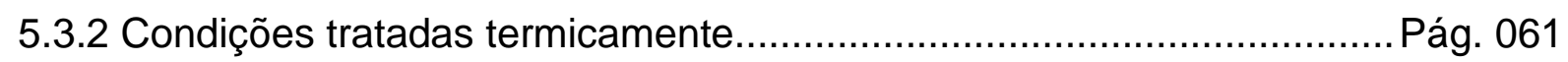

5.3.2.1 Condição $\mathrm{BQB}$ e tratado a $600^{\circ} \mathrm{C}$ por 5h...................................... Pág. 061

5.3.2.2 Condição $\mathrm{BQB}$ e tratado a $700^{\circ} \mathrm{C}$ por 5h........................................ Pág. 063

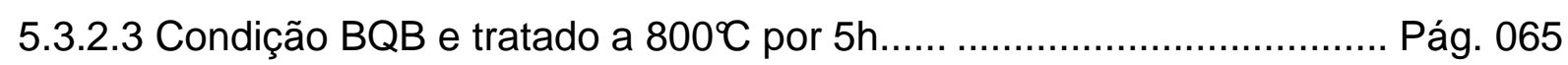

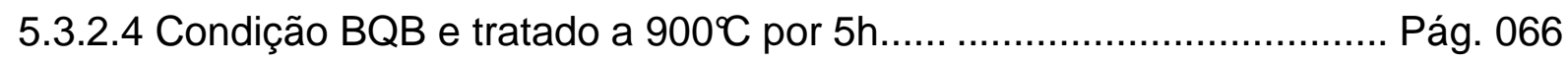

5.3.2.5 Condição $\mathrm{BQB}$ e tratado a $1000^{\circ} \mathrm{C}$ por $5 \mathrm{~h}$....................................... Pág. 068

5.3.2.6 Condição $\mathrm{BQB}$ e tratado a $1100^{\circ} \mathrm{C}$ por $5 \mathrm{~h}$...................................... Pág. 069

5.4 Análise térmica diferencial (DTA).................................................... Pág. 071

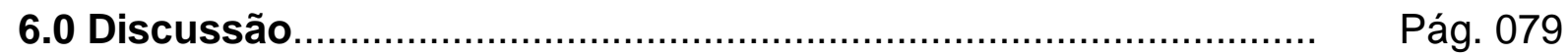

6.1 Sumário dos resultados experimentais do aço AISI 430........................ Pág. 087

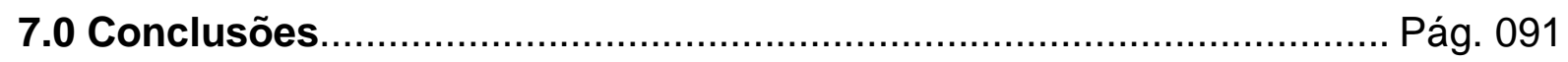

7.1 Conclusões referentes às técnicas empregadas................................... Pág. 091

7.2 Conclusões referentes a seqüência de transformações de fases do aço

AISI 430.

Pág. 092

8.0 Comentários finais e sugestão para trabalhos futuros. Pág. 094

Anexos.

Pág. 096

Anexo 1: Cartões de estrutura utilizados no refino pelo método de Rietveld.. Pág. 096

Referências Bibliográficas.

Pág. 103 


\section{Lista de Figuras}

Figura 2.1: Diagrama de equilíbrio de fases para o sistema binário $\mathrm{Fe}-\mathrm{Cr}$ extraída de (1)

Pág. 002

Figura 2.2: Estriamento em um aço inoxidável AISI430 (Fe-16,5\%Cr$0,40 \% \mathrm{Mn}-0,35 \% \mathrm{Si}-0,05 \% \mathrm{C}$, \% em peso) com $25 \%$ de alongamento. Figura obtida de (2).

Pág. 004

Figura 2.3: Energias livres de formação dos principais precipitados com carbono, nitrogênio e enxofre em aços inoxidáveis. Dados calculados com o programa ThermoCalc ${ }^{\circledR}$ V.R ${ }^{(3)}$ aliado ao banco de dados SSUB3 ${ }^{(4)}$

Pág. 005

Figura 2.4: Diagrama de Schaeffler. Diagrama obtido de (5).... Pág. 008

Figura 2.5: Micrografias em MEV de dois aços AISI 430 estudados por Liu et al. ${ }^{(6)}$ contendo diferentes teores de carbono. (a) 0,03\% de C e (b) $0,10 \%$ de $C$

Pág. 010

Figura 2.6: Precipitação do carbonitreto $\mathrm{Nb}(\mathrm{C}, \mathrm{N})$ experimental e calculada. Gráfico obtido de (7). (Fe-0,016\%C-0,69\%Mn-0,36\%Si$16,32 \% \mathrm{Cr}-0,29 \% \mathrm{Ni}-0,017 \% \mathrm{~N}-0,16 \% \mathrm{Nb}, \%$ em peso).

Figura 2.7: (a) Micrografia em MO do aço AISI430 nitretado a alta temperatura $\left(1100^{\circ} \mathrm{C}\right.$ por $\left.15 \mathrm{~min}\right)$, mostrando a presenç a de ferrita $(\alpha)$ e martensita $\left(\alpha^{\prime}\right)$. (b) Variação da concentração de nitrogênio em função da profundidade da amostra. Micrografia e gráfico obtidos de (8).

Pág. 011

Figura 2.8: Aço microligado API-X80 estudado por Ramírez ${ }^{(9)}$. (a) Micrografia em MEV mostrando apreciável quantidade de microconstituinte eutetóide contendo cementita. (b) Micrografia em $\mathrm{MO}$ do aço API-X80 mostrando a presença de um nitreto de titânio (TiN). (c) Padrão de difração de raios-X (radiação CuKa) para os precipitados extraídos com uso do reagente de Berzelius.

Pág. 013

Figura 2.9: Diagrama esquemático do funcionamento de um difratômetro. Adaptado de (10). Pág. 014

Figura 2.10: Esquema da interação de um feixe de raios-X com uma amostra cristalina com simetria cúbica simples. Figura adaptada de (10). 
Figura 2.11: Esquema do DTA mostrando as partes do sistema. Figura adaptada de (11)

Pág. 019

Figura 2.12: Determinação das inflexões do sinal do DTA pela técnica das tangentes. Figura adaptada de (12).

Pág. 020

Figura 2.13: Diagrama do DTA da liga Cu-15\%Ag (peso) coletado com taxa de aquecimento / resfriamento de $5 \mathrm{~K} / \mathrm{min}$. Determinação das inflexões do sinal do DTA por coleta. Os pontos marcados com "i" indicam as inflexões importantes e os marcados com " $n$ " as inflexões não importantes. Figura extraída de (12)

Pág. 020

Figura 2.14:. Esquema das relações entre a (a) entalpia da transformação, (b) curva derivada da entalpia com respeito a temperatura (função delta) e (c) o sinal do DTA, a Figura adaptada de (12)

Pág. 021

Figura 2.15: Influência da ciclagem térmica, sob taxa de resfriamento/aquecimento constantes, para determinação das temperaturas de equilíbrio em uma transformação exotérmica. Figura adaptada de (13).

Pág. 022

Figura 2.16: Logotipos dos principais programas de termodinâmica computacional. (a) ThermoCalc, (b) Pandat, (c) MTDADA e (d) FactSage

Pág. 024

Figura 2.17: Modelagem termodinâmica do aço SUS430 feita por JinCheng et al. (14) comparada com resultados experimentais de metalografia quantitativa. (FCC_A1 é a austenita, BCC_A2 é a ferrita). (b) Resultados do DSC. Inflexão na curva do DSC não identificada por Jin-Cheng et al. marcada em vermelho.

Pág. 028

Figura 2.18: Aço SUS430 estudado por Jin-Cheng et al. ${ }^{(14)}$ tratado em diversas temperaturas por $1 \mathrm{~h}$ seguido de têmpera em água. Micrografias em MO com ataque por reagente $30 \mathrm{~g} \mathrm{CuSO}_{4}+10 \mathrm{~g}$ $\mathrm{HCl}+60 \mathrm{~g} \mathrm{H}_{2} \mathrm{O}$. (Fase escura é a martensita e fase clara é a ferrita).

Pág. 028

Figura 2.19: Cinética de recristalização isotérmica. (a) Fração transformada em função do tempo. (b) Tamanho de grão em função do tempo. Figuras extraídas de (15).

Pág. 030

Figura 2.20: Diagrama esquemático do número de lados dos grãos em 
função da tendência destes a crescer ou serem consumidos pelo processo de crescimento de grão. Figura extraída de (16).

Pág. 031

Figura 2.21: Mecanismo de redução do número de lados de um grão durante o processo de crescimento de grão proposto por Burke e Turnbull. Figuras extraídas de (15)

Pág. 032

Figura 2.22: Mecanismo de crescimento de grão proposto por Hillert. $O$ sinal de (+) indica os grãos que crescem e o sinal (-) os grãos que estão desaparecendo. Observe que a maioria dos grãos apresentam 6 lados enquanto que o grão que está sendo consumido apresenta 5 lados. Figura extraída de (17)

Pág. 033

Figura 2.23: Mecanismo de crescimento de grão proposto por Nielsen, por coalescimento dos grãos. Freqüente em estruturas com textura preferencial. Figura extraída de (18)

Pág. 033

Figura 2.24: Cinética da recristalização do aço AISI 409 recozido a $750^{\circ} \mathrm{C}$ com diferentes graus de redução. Figura extraída de (19). Pág. 034

Figura 2.25: Micrografias em MO do aço AISI 409 laminado a frio, com diferentes graus de redução e recozido a $750^{\circ} \mathrm{C}$ por diferentes tempos. Figuras extraídas de (19).

Pág. 034

Figura 2.26: Microestruturas da seqüência temporal da recristalização para uma relação $d / D=0,07$ simuladas por Vertex. (a) é o estado inicial, (b) é uma fase intermediária e (c) é o estado final, após o término da recristalização. Figuras extraídas de (20)

Pág. 035

Figura 2.27: Cinética de recristalização calculada por simulação Vertex para variação da relação (d/D) (tamanho de sub-grão / tamanho de grão). Figura extraída de (20).

Pág. 036

Figura 4.1: (a) Cortadeira Struers modelo Secotom 10. (b) Politriz automática modelo AutoMet 2000 da Büehler.

Pág. 039

Figura 4.2: Sistema de filtração utilizado. (a) Visão geral do sistema de filtração. (b) Visão expandida do sistema de filtração indicando as partes do sistema: (1) Funil do tipo Millipore, (2) Conjunto placa porosa + Entrada da linha de vácuo, (3) Membrana de teflon de

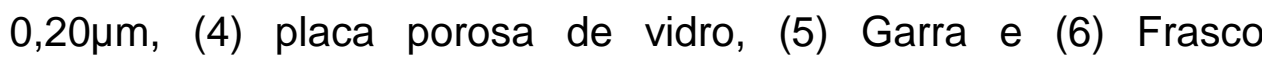
Kitassato

Pág. 041

Figura 4.3: Foto do conjunto forno e retorta. (a) visa frontal, (b) vista do 
fundo do forno (c) vista do conjunto (bomba de vácuo + retorta + forno)

Pág. 044

Figura 4.4: Ciclo térmico utilizado nas análises térmicas diferenciais (DTA)

Pág. 044

Figura 5.1: Diagramas de equilíbrio de fases do aço AISI 430 calculados com o programa ThermoCalc ${ }^{\circledR}$ aliado ao banco de dados TCFE2. (BPW é a fração mássica das fases em equilíbrio) (a) Eixo das ordenas em escala linear e (b) Eixo das ordenas em escala logarítmica

Pág. 047

Figura 5.2: Difratograma da matriz do aço AISI 430 na condição BQB e tratado a $600{ }^{\circ} \mathrm{C} / 5 \mathrm{~h}$. Difratograma obtido com radiaçã o CuK $\alpha$. (a) Difratograma completo. (b) Ampliação da região entre $60^{\circ} \mathrm{e}$ $120^{\circ}$

Pág. 050

Figura 5.3: Difratograma da matriz do aço AISI 430 na condição BQB e tratado a $11000^{\circ} / 5 \mathrm{~h}$. Difratograma obtido com radiaç ão CuK $\alpha$. (a) Difratograma completo. (b) Ampliação da região entre $60^{\circ} \mathrm{e}$ $120^{\circ}$

Pág. 051

Figura 5.4: Difratograma dos precipitados extraídos do aço AISI 430 na condição BQB. Difratograma obtido com radiação CuK $\alpha$.

Pág. 054

Figura 5.5: Difratograma dos precipitados extraídos do aço AISI 430 na condição $\mathrm{BQB}$ e tratado a $900{ }^{\circ} \mathrm{C} / 5 \mathrm{~h}$. Difratograma obtido com radiação CuK $\alpha$.

Pág. 054

Figura 5.6: Aço AISI 430 na condição BQP. Micrografias em MO. Micrografias (a) e (b) ataque por reagente Kalling's 1, campo escuro. Micrografias (c) e (d) ataque por reagente Villela.

Pág. 056

Figura 5.7: Aço AISI 430 na condição BQP. Micrografias em MEV, elétrons retroespalhados, sem ataque.

Figura 5.8: Aço AISI 430 na condição BQB. Micrografias em MO. Micrografias (a) e (b) ataque por reagente Kalling's 1. Micrografias (c) e (d) ataque por reagente Villela. Na micrografia (c) observa-se a presença de duas regiões, uma recristalizada e outra não. Observa-se a presença de carbonetos do tipo $\mathrm{M}_{23} \mathrm{C}_{6}$ nos contornos de grão.

Pág. 058 
Figura 5.9: Aço AISI 430 na condição BQB. Micrografias em MEV, elétrons retroespalhados, sem ataque

Pág. 059

Figura 5.10: Aço AISI 430 na condição BFB. Micrografias em MO. Micrografias (a) e (b) ataque por reagente Kalling's 2. Micrografias (c) e (d) ataque por reagente Villela. Carbonetos esferoidizados do tipo $\mathrm{M}_{23} \mathrm{C}_{6}$ dispersos em uma matriz ferrítica. Embora detectado pela DR-X não são observados nitretos do tipo $(\mathrm{Cr}, \mathrm{Fe})_{2} \mathrm{~N}$ por MO.

Pág. 060

Figura 5.11: Aço AISI 430 na condição BFB. Micrografias em MEV, elétrons secundários com ataque por reagente Villela. Observa-se uma dispersão de carbonetos do tipo $\mathrm{M}_{23} \mathrm{C}_{6}$ (precipitado claro) e nitretos do tipo $(\mathrm{Cr}, \mathrm{Fe})_{2} \mathrm{~N}$ (precipitados escuros) em uma matriz ferrítica

Pág. 061

Figura 5.12: Aço AISI 430 na condição $B Q B$ e tratado a $600^{\circ} \mathrm{C} / 5 \mathrm{~h}$. Micrografias em MO. Micrografias (a) e (b) ataque por reagente Kalling's 1, campo escuro. Micrografias (c) e (d) ataque por reagente Villela.

Pág. 062

Figura 5.13: Aço AISI 430 na condição $B Q B$ e tratado a $700^{\circ} \mathrm{C} / 5 \mathrm{~h}$. Micrografias em MO. Micrografias (a) e (b) ataque por reagente Kalling's 1, campo escuro. Micrografias (c) e (d) ataque por reagente Villela

Pág. 063

Figura 5.14: Aço AISI 430 na condição $B Q B$ e tratado a $700^{\circ} \mathrm{C}$ por 5 h. Micrografias em MEV, elétrons secundários, com ataque por reagente Villela.

Pág. 064

Figura 5.15: Aço AISI 430 na condição $B Q B$ e tratado a $800^{\circ} \mathrm{C} / 5 \mathrm{~h}$. Micrografias em MO com ataque por reagente Villela. Observam-se carbonetos do tipo $\mathrm{M}_{23} \mathrm{C}_{6}$ decorando os contornos de grão em uma matriz ferrítica.

Pág. 065

Figura 5.16: Aço AISI 430 na condição $B Q B$ e tratado a $900^{\circ} \mathrm{C} / 5 \mathrm{~h}$. Micrografias em MO. Micrografias (a) e (b) ataque por reagente Kalling's 1, campo escuro. Micrografias (c) e (d) ataque por reagente Villela

Pág. 066

Figura 5.17: Aço AISI 430 na condição BQB e tratado a $900^{\circ} \mathrm{C}$ por $5 \mathrm{~h}$. Micrografias em MEV sem ataque. Aço com matriz bifásica (ferrita 
+ martensita)

Pág. 067

Figura 5.18: Aço AISI 430 na condição $B Q B$ e tratado a $1000^{\circ} \mathrm{C} / 5 \mathrm{~h}$. Micrografias em MO. Micrografias (a) e (b) ataque por reagente Kalling's 1, campo escuro. Micrografias (c) e (d) ataque por reagente Villela. Observam-se ripas de martensita na figura (d), indicando claramente uma matriz bifásica ferrita/martensita

Pág. 068

Figura 5.19: Aço AISI 430 na condição $B Q B$ e tratado a $1000^{\circ} \mathrm{C}$ po $\mathrm{r}$ h. Micrografias em MEV sem ataque

Pág. 069

Figura 5.20: Aço AISI 430 na condição $B Q B$ e tratado a $1100^{\circ} \mathrm{C} / 5 \mathrm{~h}$. Micrografias em MO. Micrografia (a) ataque por reagente Kalling's 1, campo escuro. Micrografias (b), (c) e (d) ataque por reagente Villela. Observam-se ripas de martensita na figura (d), indicando claramente uma matriz bifásica ferrita/martensita

Pág. 070

Figura 5.21: Aço AISI 430 na condição BQB e tratado a $1100^{\circ} \mathrm{C}$ po $\mathrm{r}$ h. Micrografias em MEV sem ataque

Pág. 071

Figura 5.22: Ciclo térmico do ensaio de DTA do aço AISI 430 na condição $B Q B$ Pág. 072

Figura 5.23: Resultado do ensaio de DTA para a amostra do aço AISI 430 na condição $B Q$ Recozido. Diferença de potencial em relação à alumina $(\mathrm{DTA}[\mu \mathrm{V}])$ e temperatura $\left[{ }^{[} \mathrm{C}\right]$ em função do tempo do ensaio [min]

Pág. 072

Figura 5.24: Taxas de aquecimento/resfriamento em função do tempo de ensaio de DTA para o aço AISI 430 na condição BQ Recozido

Pág. 073

Figura 5.25: Derivada da curva DTA em função da temperatura para o aço AISI 430 na condição BQ Recozido.

Figura 5.26: (a) Curva do DTA em função da temperatura para o aço AISI 430 na condição $B Q$ Recozido para o ciclo térmico com taxa de resfriamento de $10^{\circ} \mathrm{C} / \mathrm{min}$. (b) Derivada da curva DTA em função da temperatura para o aquecimento do ciclo térmico. (c) Derivada da curva DTA em função da temperatura para o resfriamento do ciclo térmico.

Figura 5.27: (a) Curva do DTA em função da temperatura para o aço AISI 430 na condição $\mathrm{BQ}$ Recozido para o ciclo térmico com taxa de 
resfriamento de $5^{\circ} \mathrm{C} / \mathrm{min}$. (b) Derivada da curva DTA em função da temperatura para o aquecimento do ciclo térmico. (c) Derivada da curva DTA em função da temperatura para o resfriamento do ciclo térmico

Pág. 075

Figura 5.28: (a) Curva do DTA em função da temperatura para o aço AISI 430 na condição $B Q$ Recozido para o ciclo térmico com taxa de resfriamento de $2^{\circ} \mathrm{C} / \mathrm{min}$. (b) Derivada da curva DTA em função da temperatura para o aquecimento do ciclo térmico. (c) Derivada da curva DTA em função da temperatura para o resfriamento do ciclo térmico.

Pág. 076

Figura 5.29: Temperaturas das inflexões da curva do DTA em função da taxa de aquecimento/resfriamento em comparação com os dados de equilíbrio calculados com o programa ThermoCalc.

Pág. 078

Figura 6.1: Micrografias do aço AISI 430 nas três condições industriais como recebidas com ataque por reagente Villela. Microscopia ótica (a) BQP, (b) BQB e (c) BFB. Microscopia eletrônica de varredura (d) BFB.

Pág. 079

Figura 6.2: Micrografias em MO com ataque por reagente Villela das amostras tratadas termicamente do aço AISI 430 a (a) $600 \mathrm{C} / 5 \mathrm{~h}$, (b) $700^{\circ} \mathrm{C} / 5 \mathrm{~h}$, (c) $800^{\circ} \mathrm{C} / 5 \mathrm{~h}$, (d) $900^{\circ} \mathrm{C} / 5 \mathrm{~h}$, (e) $1000^{\circ} \mathrm{C} / 5 \mathrm{~h}$ e (f) $11000^{\circ} \mathrm{C} / 5 \mathrm{~h}$

Pág. 081

Figura 6.3: Micrografias em $\mathrm{MO}$ com ataque por reagente Villela das amostras tratadas termicamente do aço AISI 430 a (a) $700^{\circ} \mathrm{C} / 5 \mathrm{~h}$ e (b) $800^{\circ} \mathrm{C} / 5 \mathrm{~h}$

Pág. 083

Figura 6.4: Micrografias em $\mathrm{MO} \mathrm{com}$ ataque por reagente Villela das amostras tratadas termicamente do aço AISI 430 a (a) $700^{\circ} \mathrm{C} / 5 \mathrm{~h}$ e (b) BFB. Precipitados escuros são $\mathrm{Cr}_{2} \mathrm{~N}$ e precipitados claros são $(\mathrm{Cr}, \mathrm{Fe})_{23} \mathrm{C}_{6}$

Pág. 083

Figura 6.5: Fotos das amostras do aço AISI 430 antes e após tratamento térmico

Pág. 085

Figura 6.6: Fotos dos precipitados extraídos do aço AISI 430 após dissolução em reagente Berzelius e filtração à vácuo.

Pág. 085

Figura 6.7: Micrografias em MO dos precipitados extraídos para as amostras tratadas termicamente a (a) $900^{\circ} \mathrm{C} / 5 \mathrm{~h}$, (b) $1000^{\circ} \mathrm{C} / 5 \mathrm{~h} \mathrm{e}$ 
(c) $700^{\circ} \mathrm{C} / 5 \mathrm{~h}$ e para a amostra (d) BQP.

Pág. 086

Figura 6.8: Variação das temperaturas liquidus e solidus com a taxa de aquecimento/resfriamento para o aço AISI 430

Pág. 087

Figura 6.9: Esquema da histerese da temperatura de ocorrência de uma dada transformação de fase, em relação à temperatura de equilíbrio em função da taxa de aquecimento/resfriamento.

Pág. 088

Figura 6.10: Diagrama correlacionando os pontos de inflexão do ensaio de DTA do aço AISI $430 \mathrm{com}$ as temperaturas e as transformações de fases em equilíbrio calculadas com o programa ThermoCalc. As linhas na cor laranja tracejadas têm efeito somente para a indicação da reação, sendo que estas não foram comprovadas com significância pelo ensaio de DTA (inflexões pouco significativas)

Pág. 090 


\section{Lista de Tabelas}

Tabela 2.1: Composições químicas dos principais aços inoxidáveis ferríticos $^{(21)}$. (C, Mn, $\mathrm{Si}, \mathrm{Ni}, \mathrm{P}$ e S, teores máximos).

Pág. 003

Tabela 2.2: Insolubilidade de precipitados no reagente de Berzelius segundo Burke ${ }^{(22)}$

Pág. 012

Tabela 2.3: Fator de multiplicidade para os sistemas cúbicos

Pág. 016

Tabela 4.1: Composição química do aço AISI 430 (\% em massa)

Pág. 038

Tabela 4.2: Dados da programação da politriz utilizada.

Pág. 039

Tabela 4.3: Reagentes para os ataques metalográficos ${ }^{(1)}$...

Pág. 040

Tabela 4.4: Composição química do reagente utilizado para dissolução.

Pág. 040

Tabela 4.5: Lista de ensaios de extração de precipitados realizados no aço AISI 430

Pág. 041

Tabela 5.1: Seqüência de solidificação em equilíbrio do aço AISI 430.

Tabela 5.2: Resultados da análise de Rietveld para os difratogramas da matriz

Pág. 049

Tabela 5.3:Resultados da análise de Rietveld para os difratogramas dos precipitados extraídos. (a, b e c são os parâmetros de rede, sempre em $\AA$ ). . As respectivas estruturas cristalinas e parâmetros de rede da literatura são apresentadas no Anexo 1.

Pág. 053

Tabela 5.4: Análise química via EDS (\% em peso) do aço AISI 430 na condição BQP, referente à micrografia da figura $5.7(\mathrm{~d})$

Pág. 055

Tabela 5.5: Análise química via EDS (\% em peso) do aço AISI 430 na condição $\mathrm{BQB}$, referente à micrografia da figura $5.9(\mathrm{~d})$

Pág. 058

Tabela 5.6: Análise química via EDS (\% em peso) do aço AISI 430 na condição $B Q B$, referente à micrografia da figura $5.11(d)$.

Pág. 060

Tabela 5.7: Análise química via EDS (\% em peso) do aço AISI 430 na condição $\mathrm{BQB}$ e tratado a $700^{\circ} \mathrm{C} / 5 \mathrm{~h}$, referente à micrografia da figura $5.14(d)$

Pág. 064

Tabela 5.8: Análise química via EDS (\% em peso) do aço AISI 430 na condição $\mathrm{BQB}$ e tratado a $900^{\circ} \mathrm{C} / 5 \mathrm{~h}$, referente à micrografia da figura $5.17(\mathrm{c})$

Tabela 5.9: Análise química via EDS (\% em peso) do aço AISI 430 na condição $\mathrm{BQB}$ e tratado a $1000^{\circ} \mathrm{C} / 5 \mathrm{~h}$, referente à mic rografia da 
figura 5.19 (c)

Pág. 069

Tabela 5.10: Análise química via EDS (\% em peso) do aço AISI 430 na condição $\mathrm{BQB}$ e tratado a $1100^{\circ} \mathrm{C} / 5 \mathrm{~h}$, referente à mic rografia da figura $5.21(\mathrm{c})$

Pág. 071

Tabela 5.11: Inflexões da curva do DTA em função da temperatura para os ciclos térmicos do ensaio de DTA do aço AISI 430 na condição $B Q B$

Pág. 077

Tabela 6.1: Resultados da difração de raios- $X$. As porcentagens de $(\mathrm{Cr}, \mathrm{Fe})_{2} \mathrm{~N}$ e de $(\mathrm{Cr}, \mathrm{Fe})_{23} \mathrm{C}_{6}$ foram calculadas a partir da tabela 5.10, excluindo-se os produtos de extração. Os parâmetros de rede a e c são apresentados em Á

Pág. 080

Tabela 6.2: Resultados da difração de raios- $X$. As porcentagens de $(\mathrm{Cr}, \mathrm{Fe})_{2} \mathrm{~N}$ e de $(\mathrm{Cr}, \mathrm{Fe})_{23} \mathrm{C}_{6}$ foram calculadas a partir da tabela 5.10, excluindo-se os produtos de extração. Os parâmetros de rede a e c são apresentados em Á.

Pág. 082

Tabela 6.3: Relação entre os parâmetros de rede calculados e da literatura para o carboneto do tipo $\mathrm{Cr}_{23-\mathrm{x}} \mathrm{Fe}_{\mathrm{X}} \mathrm{C}_{6}$.

Pág. 084

Tabela 6.4: Produtos do processo de extração de precipitados identificados por difração de raios-X do aço AISI 430 .

Pág. 084

Tabela 6.5: Seqüência de solidificação em equilíbrio do aço AISI 430.

Pág. 087 


\subsection{Introdução}

Neste trabalho objetivou-se a caracterização da seqüência de precipitação do aço inoxidável ferrítico do tipo AISI 430 convencional. A caracterização da seqüência de precipitação é uma importante ferramenta para a previsão e avaliação da seqüência de tratamentos termomecânicos a que os aços são submetidos. A presença de determinadas fases ao final do processo de laminação produz, em geral, falhas superficiais ao término da laminação, que têm se mostrado onerosas na produção destes aços para aplicações em linha branca e principalmente em peças estampadas.

Como meio de caracterizar a seqüência de precipitação destes aços, neste trabalho foram estudadas nove condições do aço AISI 430 convencional, sendo três condições industriais e seis condições tratadas termicamente, partindo-se da condição industrial BQB (laminado a quente e recozido). Cada uma das amostras foi submetida a análises por microscopia ótica e eletrônica de varredura, difração de raios-X do aço e extração de precipitados com análise dos precipitados por difração de raios- $X$.

Foi ainda realizado um ensaio de DTA, para o aço na condição $B Q B$, sendo este ensaio realizado com três taxas de resfriamento diferentes $(10 \% \mathrm{~min}, 5 \% \mathrm{~min}$ e $2 \%$ min) para possibilitar a determinação das temperaturas de equilíbrio das transformações de fases e a estimativa da cinética de transformações de fases.

Para comparar os resultados obtidos, a seqüência de precipitação em equilíbrio foi calculada com o programa ThermoCalc ${ }^{\circledR}$ e os dados foram comparados com os dados experimentais.

No item 2 está apresentada a revisão bibliográfica. No item 3 são apresentados os objetivos deste trabalho. No item 4 está apresentada a metodologia utilizada. No item 5 são apresentados os resultados experimentais obtidos e no item 6 é apresentada a discussão dos resultados obtidos. No item 7 são apresentadas as conclusões obtidas. E, por fim, no item 8 são apresentadas sugestões para trabalhos futuros. 


\subsection{Revisão Bibliográfica}

Os aços inoxidáveis podem ser classificados em função das fases presentes na sua matriz, a qual pode ser martensítica, austenítica ou ferrítica. Existem ainda os aços inoxidáveis dúplex os quais são compostos por matrizes bifásicas compostas pelas fases austenita e ferrita ${ }^{(23)}$.

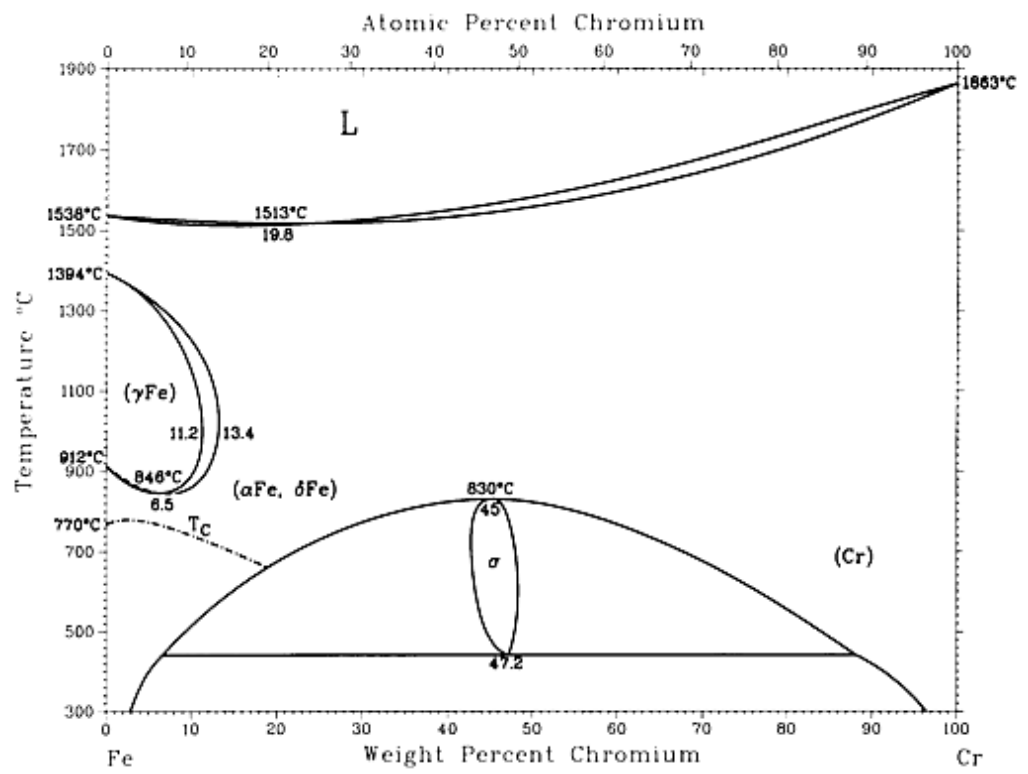

Figura 2.1: Diagrama de equilíbrio de fases para o sistema binário Fe-Cr extraída de (1).

Os aços inoxidáveis ferríticos apresentam uma matriz predominantemente ferrítica com a presença de carbonetos, nitretos e carbonitretos, em geral, de cromo, podendo também ser de elementos de liga presentes no aço tais como Nb e Ti. Para que a matriz seja ferrítica, estes aços apresentam, em geral, teores superiores a $13,4 \%$ em peso de cromo ${ }^{(23)}$, de acordo com o diagrama de equilíbrio de fases binário $\mathrm{Fe}-\mathrm{Cr}$ da figura 2.1.

A definição formal de aços inoxidáveis ferríticos estabelece que estes aços apresentam matriz composta pela fase ferrita $(\mathrm{CCC}-\mathrm{Cl} 2)$ em todas as temperaturas, podendo apresentar precipitados como fase sigma, carbonetos, nitretos e carbonitretos. Entretanto, segundo Costa e Silva e Mei ${ }^{(24)}$, curiosamente muitos dos aços inoxidáveis ferríticos, como o AISI430 e o AISI446, não atendem a esta definição podendo apresentar até $50 \%$ de austenita acima de $800^{\circ} \mathrm{C}$ e quando resfriados apresentam uma microestrutura bifásica contendo ferrita e martensita. Os aços inoxidáveis ferríticos, em geral, são comercializados na condição recozida, sendo que é freqüente a realização de tratamentos térmicos posteriores em temperaturas da ordem de $750^{\circ} \mathrm{C}$, temperatura na qual a martensita se decompõe 
em ferrita e carbonetos gerando uma matriz quase completamente ferrítica ${ }^{(24)}$.

$\mathrm{Na}$ tabela 2.1 apresentam-se as composições químicas dos principais aços inoxidáveis ferríticos.

Tabela 2.1: Composições químicas dos principais aços inoxidáveis ferríticos ${ }^{(21)}$. (C, Mn, Si, Ni, P e
S, teores máximos.)
\begin{tabular}{ccccccccl} 
& & & & & \\
\hline AISI & $\mathbf{C}$ & $\mathbf{M n}$ & $\mathbf{S i}$ & $\mathbf{C r}$ & $\mathbf{N i}$ & $\mathbf{P}$ & $\mathbf{S}$ & Outros elementos \\
\hline $\mathbf{4 3 0}$ & 0,12 & 1,00 & 1,00 & $16,0-18,0$ & --- & 0,04 & 0,03 & --- \\
\hline $\mathbf{4 3 0 F}$ & 0,12 & 1,25 & 1,00 & $16,0-18,0$ & --- & 0,06 & 0,15 & Mín.0,6 Mo \\
\hline $\mathbf{4 3 0 F S e}$ & 0,12 & 1,25 & 1,00 & $16,0-18,0$ & --- & 0,06 & 0,06 & $0,15 \%$ mín. Se \\
\hline $\mathbf{4 3 4}$ & 0,12 & 1,00 & 1,00 & $16,0-18,0$ & --- & 0,04 & 0,03 & $0,75-1,25 \mathrm{Mo}$ \\
\hline $\mathbf{4 3 9}$ & 0,07 & 1,00 & 1,00 & $17,0-19,0$ & 0,50 & 0,04 & 0,03 & $0,15 \mathrm{Al}, 12 \times(\% \mathrm{C})$ mín.-1,10 Ti \\
\hline $\mathbf{4 4 2}$ & 0,20 & 1,00 & 1,00 & $18,0-23,0$ & --- & 0,04 & 0,03 & --- \\
\hline $\mathbf{4 4 6}$ & 0,20 & 1,50 & 1,00 & $23,0-27,0$ & --- & 0,04 & 0,03 & $0,25 \mathrm{~N}$ \\
\hline
\end{tabular}

Observa-se da tabela 2.1 que os aços inoxidáveis ferríticos apresentam teores de cromo superiores a $16 \%$ em peso. Este teor de cromo é o responsável pela elevada resistência à corrosão destes aços, porém, também representa o motivo principal para a ocorrência de quatro mecanismos de fragilização ${ }^{(21)}$ :

- Fragilização por precipitação de fase sigma: a fragilização pela precipitação de fase sigma ocorre somente em aços inoxidáveis ferríticos que contém mais de $20 \%$ em peso de $\mathrm{Cr}$, sendo mais evidenciada em aços contendo entre $25 \%$ e $30 \%$, quando estes são aquecidos entre 500 e $8000^{\circ}$. A presença de Mo, Si, Ni e Mn também é responsável pela maior incidência de fragilização pela fase sigma visto que estes elementos estabilizam esta fase. A fragilização pela fase sigma provoca a diminuição da ductilidade e da tenacidade abaixo de $6000^{\circ} \mathrm{C}$.

- Fragilização de $475^{\circ} \mathrm{C}$ : precipitação da fase $\alpha^{\prime}$ a partir da fase ferrita $(\alpha)$ por mecanismo da decomposição espinoidal da fase ferrita. Esta decomposição ocorre devido a partição de cromo entre as duas fases, deixando uma ferrita rica em cromo ( $\alpha$ ') e outra pobre $(\alpha)$. Esta fragilização é tão mais evidenciada quanto maior for o tempo e a temperatura do tratamento térmico e a porcentagem de cromo no aço. Esta fragilização pode ser removida através do tratamento térmico em temperaturas superiores a $550^{\circ} \mathrm{C}$.

- Fragilização à alta temperatura: também chamada de sensitização. Ocorre devido a partição de cromo na matriz para a precipitação de carbonetos, em geral, de cromo nos contornos de grão, causando a redução da resistência à corrosão nas regiões em torno dos precipitados formados. A fragilização de alta temperatura ocorre em aços com concentrações de médias a elevadas 
de intersticiais, tais como o carbono e o nitrogênio, quando o aço é tratado em temperaturas superiores a $950^{\circ} \mathrm{C}$ e resfriados ao ar. Um modo de se evitar esta fragilização é através da adição de elementos de liga que estabilizem os intersticiais ou aumentem a solubilidade das fases da matriz.

- Estriamento: Um defeito freqüente nos aços ferríticos refere-se a formação de estrias durante o processo de laminação ${ }^{(25 ; 2)}$, figura 2.2 . As estrias caracterizam-se pelo enrugamento da superfície, sendo que este enrugamento possui tipicamente entre $20-50 \mu \mathrm{m}$ de profundidade. A formação de estrias pode ser associada a diversos fatores tais como a segregação de elementos de liga como o Mo, Cr e C, e a presença de textura ${ }^{(26)}$.

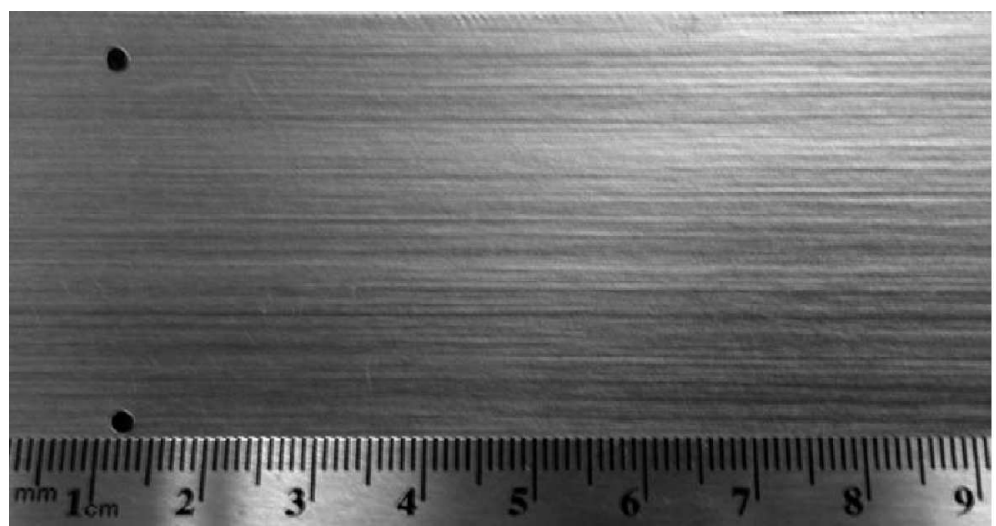

Figura 2.2: Estriamento em um aço inoxidável AISI430 (Fe-16,5\%Cr-0,40\%Mn-0,35\%Si-0,05\%C, \% em peso) com $25 \%$ de alongamento. Figura obtida de (2).

No item 2.1 serão apresentados os efeitos dos principais elementos de liga nos aços inoxidáveis. No item 2.2 serão descritas as principais características microestruturais dos aços inoxidáveis ferríticos estabilizados e não estabilizados. No item 2.3 serão apresentados dados referentes aos mecanismos de transformações de fases que foram observados nos resultados experimentais.

\subsection{Efeito dos elementos de liga nos aços inoxidáveis ferríticos}

Os elementos de liga comumente encontrados nos aços inoxidáveis ferríticos para estabilização da ferrita são: nióbio, titânio, zircônio e vanádio ${ }^{(23)}$. Estes elementos são adicionados, em geral, para reagir com o carbono e o nitrogênio, em solução sólida, de modo a formar carbonetos, nitretos e carbonitretos destes elementos, deixando-se o cromo em solução na matriz, sem que haja a precipitação de carbonetos ou nitretos de cromo. De modo a possibilitar que a precipitação destes carbonetos, nitretos e carbonitretos ocorra, sem que haja a formação de 
precipitados com cromo, os elementos de liga devem necessariamente apresentar uma energia livre de formação inferior aos demais precipitados com cromo. Na figura 2.3 são apresentadas as energias livres de formação dos principais precipitados.

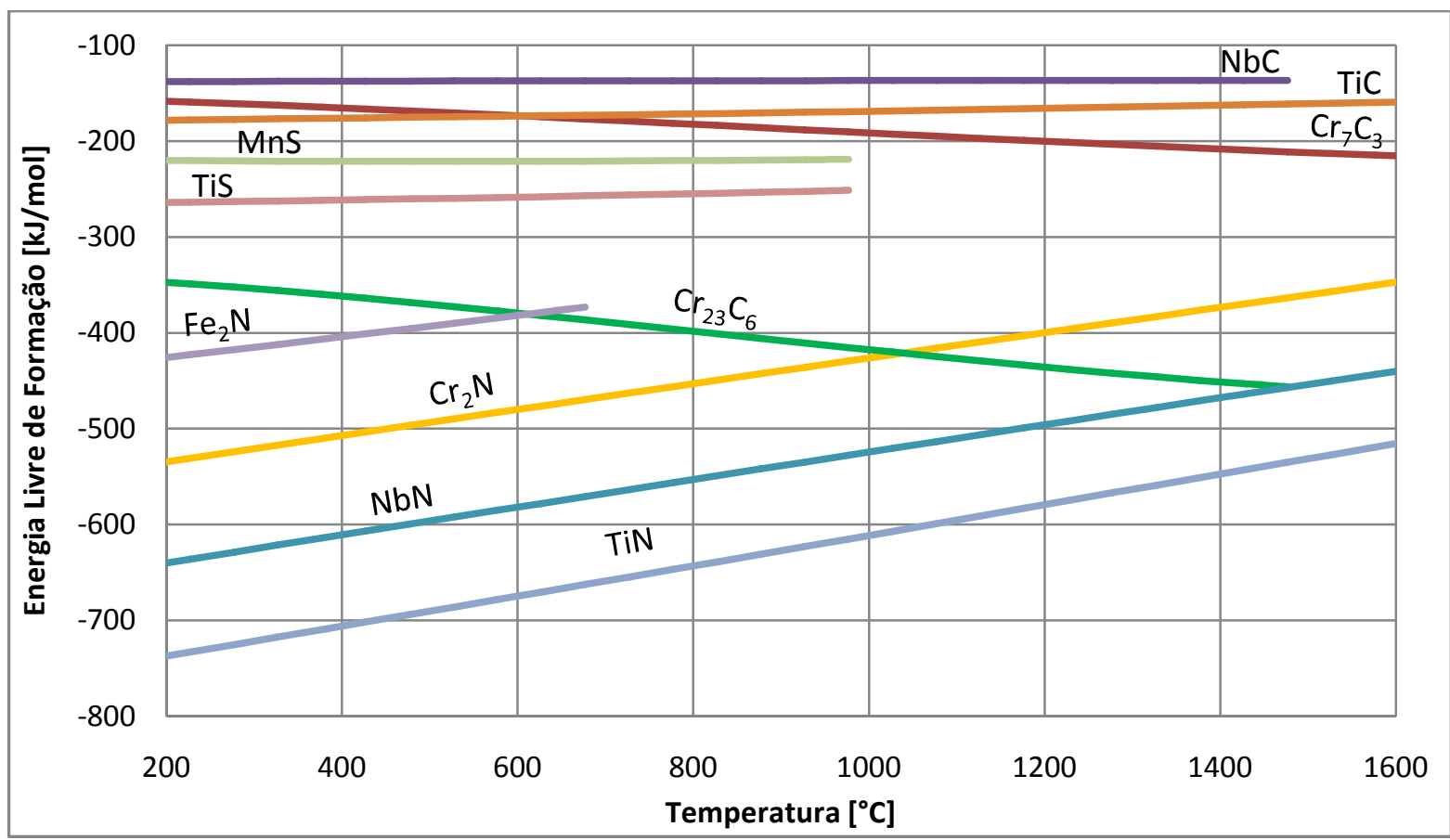

Figura 2.3: Energias livres de formação dos principais precipitados com carbono, nitrogênio e enxofre em aços inoxidáveis. Dados calculados com o programa ThermoCalc ${ }^{\circledR}$ v.R ${ }^{(3)}$ aliado ao banco de dados SSUB3 ${ }^{(4)}$.

Da figura 2.3 observa-se que as energias livres de formação de precipitados de $\mathrm{Ti}$ e $\mathrm{Nb}(\mathrm{TiN}, \mathrm{NbN})$ são menores do que a energia livre de formação do $\mathrm{Cr}_{2} \mathrm{~N}$ em todas as temperaturas. Observa-se também que a precipitação de $\mathrm{Cr}_{23} \mathrm{C}_{6}$ pode ser inibida pela precipitação de carbonitretos do tipo $M(C, N)(M=N b, T i)$, dependendo da atividade química dos elementos na matriz do aço e da cinética de precipitação.

Observa-se também que a precipitação de MnS pode ser inibida (ou reduzida) pela precipitação de TiS ${ }^{(27 ; 28 ; 29)}$, sendo formado inicialmente um núcleo de TiS (no estado líquido) sobre o qual cresce o MnS, sendo o teor de MnS fortemente dependente do teor restante de enxofre disponível após a precipitação do TiS. A literatura também apresenta a possibilidade de formação de $\mathrm{Ti}_{4} \mathrm{C}_{2} \mathrm{~S}_{2}$ no estado líquido, o qual aprisionaria simultaneamente o C e S.

O elemento de liga mais utilizado para estabilização de aços inoxidáveis ferríticos é o titânio. Este elemento é altamente reativo com o nitrogênio, carbono e enxofre formando os precipitados TiN, TiC e TiS, respectivamente. Quando na presença de $\mathrm{C}$ e $\mathrm{N}$, há a formação de $\mathrm{Ti}(\mathrm{C}, \mathrm{N})$ devido a solubilidade mútua do Ti em ambas as estruturas cristalinas (CFC - cF4). 
Com a formação de precipitados mais estáveis que os de cromo, a estabilização com o Ti eleva a temperatura de sensitização (inibindo-a) dado ao aprisionamento do $\mathrm{C}$ e do $\mathrm{N}$ na forma de $\mathrm{TiN}, \mathrm{TiC}$ ou $\mathrm{Ti}(\mathrm{C}, \mathrm{N})$. Assim para que ocorra a sensitização é necessário que haja a dissolução (parcial/total) dos precipitados de Ti, liberando para a matriz o carbono e o nitrogênio, de modo a permitir a formação de $\mathrm{Cr}_{2} \mathrm{~N}$ e de $(\mathrm{Cr}, \mathrm{Fe})_{23} \mathrm{C}_{6}$. Como a estabilidade química dos precipitados de $\mathrm{Ti}$ é maior que a dos precipitados de $\mathrm{Cr}$, além da existência de aspectos cinéticos para a dissolução dos precipitados de titânio de modo a permitir a formação de precipitados de $\mathrm{Cr}$, a temperatura de sensitização irá aumentar em função do precipitado formado, podendo ser descrita por uma curva em "C" em um diagrama TTT (Tempo - Temperatura - Transformação).

A resistência à corrosão por pite também é melhorada visto que o Ti tende a consumir o S dissolvido para formação TiS ao invés do MnS, que é conhecido por ser o principal local de iniciação dos sítios de corrosão. Além destas qualidades, os carbonetos e nitretos de Ti atuam também como sítios de nucleação de outros precipitados, permitindo a obtenção de estruturas mais refinadas ${ }^{(23)}$.

Por outro lado, adições de $\mathrm{Ti}$ acima das necessárias para consumir o $\mathrm{C}$ e $\mathrm{N}$ do aço, fazem com que haja o endurecimento por solução sólida, reduzindo a ductilidade do aço. Uma desvantagem importante para a adição do Ti refere-se ao tempo necessário para o resfriamento do aço, pois caso o mesmo seja resfriado rapidamente, não haverá tempo suficiente para formação de $\mathrm{Ti}(\mathrm{C}, \mathrm{N})$, podendo ocorrer a precipitação deste carbonitreto contendo algum teor de $\mathrm{Cr}$, ou seja, $(\mathrm{Ti}, \mathrm{Cr})(\mathrm{C}, \mathrm{N})$, e por conseqüência, haverá um empobrecimento em $\mathrm{Cr}$ da região em torno do precipitado que conduzirá a uma menor resistência à corrosão nestas regiões ${ }^{(23)}$. Alguns autores ${ }^{(30)}$ relataram a possibilidade de obtenção de superfícies finais de qualidade inferior nos aços estabilizados ao $\mathrm{Ti}$ em relação aos aços não estabilizados ou estabilizados com outros elementos de liga.

Um dos principais motivos para a adição do Ti reside na possibilidade de adição de Ti na forma de ferro-liga de Ti, que é comercialmente mais barata que as demais ferro-ligas, e inibe parcialmente a volatilização do Ti quando este é adicionado na panela de refino em relação à adição deste elemento puro.

Um dos modos de reduzir as desvantagens de adições de titânio é através da adição de nióbio. Embora o $\mathrm{Nb}$ apresente uma cinética de formação de precipitados mais lenta que o Ti, ele promove a formação de carbonetos ( $\mathrm{NbC}$ ) e carbonitretos $(\mathrm{Nb}(\mathrm{C}, \mathrm{N}))$ que ajudam a inibir a sensitização. 
As vantagens do uso de $\mathrm{Nb}$ ao invés do Ti são:

- formação de pequenos precipitados, em geral, com morfologia esférica;

- a qualidade final da superfície do produto não sofre influências;

- os efeitos de super-adição de $\mathrm{Nb}$ não geram inconvenientes como o Ti e, em geral, são graduais com o teor de $\mathrm{Nb}$ em solução;

- a sensitização após resfriamento de elevadas temperaturas não é tão pronunciada como no caso dos aços estabilizados ao $\mathrm{Ti}^{(23)}$, principalmente devido a maior estabilidade dos precipitados de Ti para o aprisionamento do C.

As principais desvantagens do uso do $\mathrm{Nb}$ estão associadas com a perda da ductilidade de soldas e ao custo do nióbio puro.

Sim et al. ${ }^{(31)}$ estudaram aços inoxidáveis estabilizados e não estabilizados ao $\mathrm{Nb}$ e observaram que a adição de $\mathrm{Nb}$ gera um efeito de ancoramento ("pinning") dos contornos de grão que reduz as taxas de crescimento de grão. Eles observaram também que com o aumento do tempo de envelhecimento houve considerável redução do limite de escoamento, provavelmente devido à precipitação e a redução do teor de $\mathrm{Nb}$ em solução sólida. Em relação aos precipitados, nos aços em que eles trabalharam [Fe-15\%Cr- $(0,008 \sim 0,031) \% \mathrm{C}-0,015 \% \mathrm{~N}-0,8 \% \mathrm{Si}-0,4 \% \mathrm{Mn}$ $(0 \sim 0,8) \% \mathrm{Nb}$; \% em peso] foram observados por microscopia eletrônica de transmissão (MET) precipitados do tipo $\mathrm{Nb}(\mathrm{C}, \mathrm{N})$ e $\mathrm{Fe}_{2} \mathrm{Nb}$ (fase de laves) e $\mathrm{M}_{6} \mathrm{C}$, sendo que a observação de $\mathrm{M}_{6} \mathrm{C}$ ocorreu somente em amostras envelhecidas por mais de $60 \mathrm{~h}$ a $700{ }^{\circ} \mathrm{C}$, e a precipitação da fase de la ves ocorreu somente para as amostras com elevado teor de $\mathrm{Nb}(\% \mathrm{Nb}>0,38 \%$ em peso) e baixo teor de $\mathrm{C}$ (\%C $<0,01 \%$ em peso). Fujita et al. ${ }^{(32)}$ também observaram que a precipitação de fase de laves e de carbonetos do tipo $\mathrm{M}_{6} \mathrm{C}$ ocorrem somente para elevados teores de $\mathrm{Nb}$ e baixos teores de $\mathrm{C}$.

Fujita et al. ${ }^{(33)}$ estudaram o aço Fe-19,6\%Cr-0,2\%Si-0,3\%Mn-0,014\%C$0,78 \% \mathrm{Nb}-0,016 \% \mathrm{~N}, \%$ em peso, em diversas condições de tratamentos térmicos. Eles verificaram que dado ao baixo teor de $\mathrm{C}$ e elevado teor de $\mathrm{Nb}$, houve a precipitação de: fase de laves $\left(\mathrm{Fe}_{2} \mathrm{Nb}\right), \mathrm{M}_{6} \mathrm{C}\left(\mathrm{Fe}_{3} \mathrm{Nb}_{3} \mathrm{C}\right)$ e $\mathrm{Nb}(\mathrm{C}, \mathrm{N})$ nos estágios iniciais do envelhecimento (1h) nas temperaturas de 900, 950 e $1000^{\circ} \mathrm{C}$ após solubilização a $1250^{\circ} \mathrm{C} / 30 \mathrm{~min}$. No entanto, em estági os avançados (100h) eles observaram a redução do teor de $\mathrm{Nb}(\mathrm{C}, \mathrm{N})$ indicando a decomposição deste carbonitreto em prol da formação de $\mathrm{NbN}$ e de $\mathrm{M}_{6} \mathrm{C}$. Segundo estes autores, as fases em equilíbrio neste aço parecem ter a seguinte seqüência de equilíbrio: 


$$
\alpha \rightarrow \alpha+\mathrm{Nb}(\mathrm{C}, \mathrm{N})+\mathrm{Fe}_{2} \mathrm{Nb}+\mathrm{Fe}_{3} \mathrm{Nb}_{3} \mathrm{C} \rightarrow \alpha+\mathrm{NbN}+\mathrm{Fe}_{3} \mathrm{Nb}_{3} \mathrm{C}
$$

A estabilização de aços inoxidáveis com adições simultâneas de $\mathrm{Nb}$ e Ti é uma forma de acoplar os benefícios de ambos, e compensar as desvantagens. As principais vantagens desta combinação são ${ }^{(23 ; 34)}$ :

- O elemento Ti migra para as trincas de soldagem compensando os efeitos deletérios do $\mathrm{Nb}$, através da geração de nitretos do tipo TiN, que atuam como sítios de nucleação no líquido, produzindo microestruturas mais refinadas e com melhores propriedades mecânicas;

- A adição de $\mathrm{Nb}$ reduz a precipitação de grandes precipitados de $\mathrm{Ti}(\mathrm{C}, \mathrm{N})$, possibilitando a redução do teor de Ti adicionado para estabilização;

A principal desvantagem da estabilização simultânea com Nb e Ti está na variação da resistência à corrosão. Os aços estabilizados simultaneamente com Nb e Ti apresentam resistência à corrosão intermediária entre os aços estabilizados somente com $\mathrm{Nb}$ ou somente com $\mathrm{Ti}^{(23)}$. A variação da resistência a corrosão é atribuída a corrosão generalizada e a intergranular, devido a formação de precipitados mistos dos tipos $(\mathrm{Cr}, \mathrm{Nb}, \mathrm{Ti})(\mathrm{C}, \mathrm{N})$ e $(\mathrm{Cr}, \mathrm{Ti})_{2}(\mathrm{C}, \mathrm{N})$, no entanto 0 mecanismo de corrosão não é claramente especificado pela literatura ${ }^{(23 ; 34)}$.

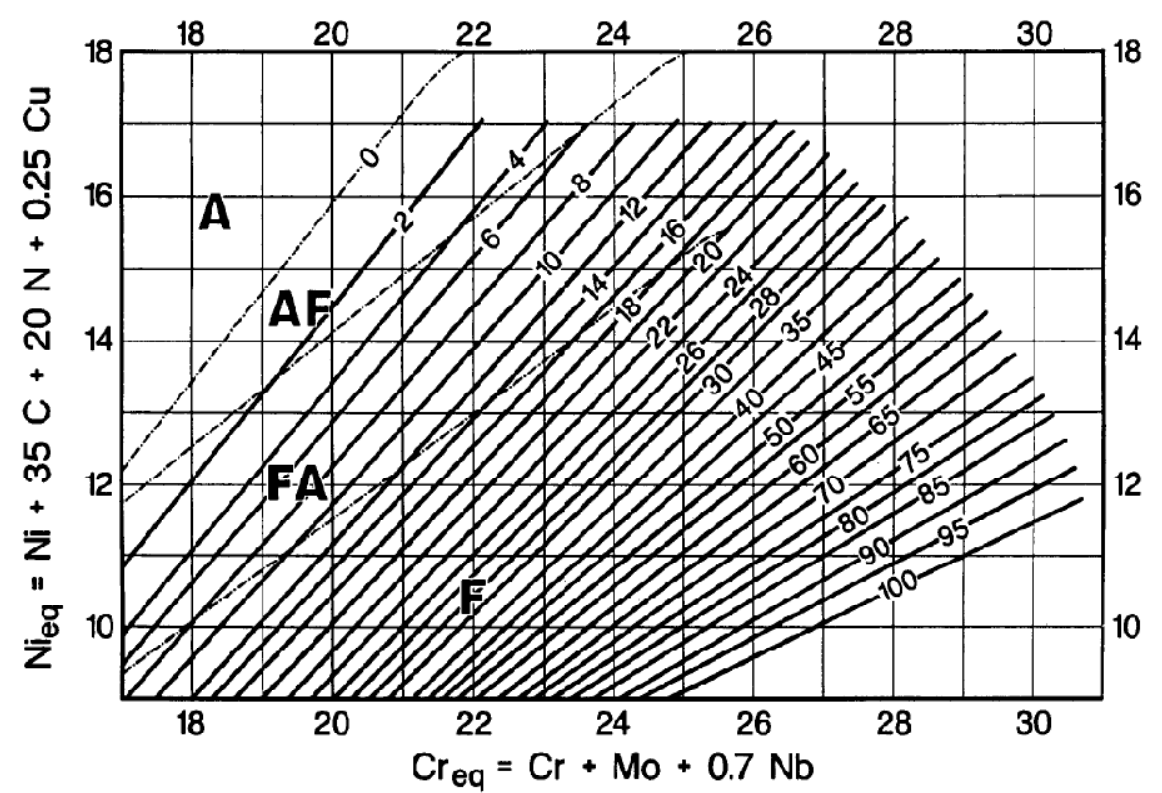

Figura 2.4: Diagrama de Schaeffler. Diagrama obtido de (5).

Uma das formas, parcialmente empíricas, de avaliação dos efeitos dos elementos de liga nos aços inoxidáveis é através do uso do diagrama de Schaeffler. Neste diagrama, representando uma "isoterma" pseudo-binária, entra-se com a composição de cromo equivalente $\left(\mathrm{Cr}_{e q}=\% \mathrm{Cr}+\% \mathrm{Mo}+0,7 \cdot \% \mathrm{Nb}\right)$ e com a 
composição de níquel equivalente $\left(N i_{e q}=\% N i+35 \cdot \% C+20 \cdot \% N+0.25 \cdot \% C u\right)$, e avalia-se qual o campo de equilíbrio para a matriz (austenita, ferrita ou bifásica). Entretanto, este diagrama não prevê a presença de precipitados nos aços. Na figura 2.4, apresenta-se uma edição recente deste diagrama feita por Feldstein e Lake ${ }^{(5)}$.

No entanto, outros elementos de liga podem gerar efeitos diferentes tais como o molibdênio, o vanádio, o níquel e o cobre.

O molibdênio é um elemento alfagênico, que promove a precipitação das fases martensita $(\alpha$ ), Chi $(\chi)$ e sigma $(\sigma)$. Adições de molibdênio, em geral, situamse entre $1 \%$ e $5 \%$ em peso, e atuam para elevar a resistência à corrosão, (especialmente corrosão por pite), a resistência mecânica e a dureza. Em geral, as desvantagens associam-se com o aumento da temperatura de transição dúctil-frágil, aumento da resistência ao impacto e redução da tenacidade ${ }^{(35)}$.

O níquel é um elemento gamagênico, que promove o aumento da resistência mecânica (especialmente do limite de escoamento), reduz a temperatura de transição dúctil-frágil e aumenta a resistência à corrosão. Entretanto, o Ni reduz a resistência à corrosão sob-tensão. Em geral, pode ser adicionado entre 2\% e 4\% em peso de $\mathrm{Ni}^{(35)}$.

O cobre é um elemento gamagênico, que promove o aumento da resistência à corrosão e melhora a usinagem a frio. Entretanto, o $\mathrm{Cu}$ aumenta a susceptibilidade à corrosão sob-tensão. Em geral, adiciona-se entre 0,2\% e 0,7\% em peso para esta finalidade ${ }^{(35)}$.

\subsection{Microestrutura dos aços inoxidáveis ferríticos}

Yan et al. ${ }^{(34)}$ estudaram o aço $\mathrm{Fe}-11,7 \% \mathrm{Cr}-0,2 \% \mathrm{Ti}-0,2 \% \mathrm{Nb}-0,012 \% \mathrm{C}$ $0,009 \% \mathrm{~N}-0,4 \% \mathrm{Si}-0,5 \% \mathrm{Mn}$ (\% em peso) após envelhecimento a $9400^{\circ} \mathrm{C}$ por $5 \mathrm{~min}$ e resfriamento ao ar, partindo-se do estado bruto de fundição e laminado a frio. Nesta condição eles observaram por MEV a presença de precipitados de TiN com geometria próxima à cúbica, tamanho da ordem de $3 \mu \mathrm{m}$, concentrado principalmente nos contornos de grão. Através do emprego de MET eles observaram a presença de precipitados de $\mathrm{NbC}$ (esférico) e de $\mathrm{Fe}_{2} \mathrm{Nb}$ (plaquetas) com tamanho da ordem de 150-300nm. Estes precipitados foram diferenciados através de análise química por EDS e pela diferença em suas morfologias.

Askoy et al. ${ }^{(36)}$ estudaram variações do aço inoxidável ferrítico (Fe-18\%Cr0,25\%Mn-0,28\%Si-0,4\%C) com adições de $1 \%$ em peso de Mo, $\mathrm{V}$, Ti e Nb para 
avaliação dos efeitos de elementos de liga nas propriedades mecânicas. Eles observaram que em todas as amostras com adições de elementos de liga houve redução da dureza da superfície (-12\% para Mo e Ti, -20\% para V e $-22 \%$ para $\mathrm{Nb}$ ), entretanto, as adições elevaram a resistência ao desgaste abrasivo (+14\% para Nb, $+15 \%$ para $\mathrm{V},+16 \%$ para Mo e $+19 \%$ para $\mathrm{Ti})$. A tenacidade, avaliada por ensaio de impacto Charpy, manteve-se constante para todas as amostras.

Liu et al. ${ }^{(6)}$ estudaram dois aços do tipo AISI430 (Fe-16,10\%Cr-0,13\%Ni0,09\%Mn-0,55\%Si, \% em peso) com variação do teor de carbono $(0,10$ e 0,03\% em peso), após tratamentos térmicos nas temperaturas de $1200^{\circ} \mathrm{C}$ e $12500^{\circ} \mathrm{C}$ por $10 \mathrm{e}$ $20 \mathrm{~min}$ seguidos por têmpera com taxa superior a $300^{\circ} \mathrm{C} / \mathrm{s}$. Eles observaram que $\mathrm{o}$ aço contendo $0,10 \%$ de $\mathrm{C}$ apresentou precipitados do tipo $\mathrm{M}_{23} \mathrm{C}_{6}$ e provavelmente apresentou campo bifásico austenita/ferrita a alta temperatura. Já o aço contendo 0,03\% de carbono manteve-se monofásico nestes tratamentos térmicos. Na figura 2.5 apresentam-se as micrografias obtidas por Liu et al. ${ }^{(6)}$ para ambos os aços, tratados a $1200{ }^{\circ} \mathrm{C}$ por $10 \mathrm{~min}$. Nestas micrografias observa-se que o aço com 0,03\% de carbono apresentou somente recristalização e crescimento de grão, enquanto que o aço com $0,10 \%$ de carbono apresentou precipitação de carbonetos do tipo $\mathrm{M}_{23} \mathrm{C}_{6}$ nos contornos de grão. Observa-se também a presença de duas colorações na ferrita.

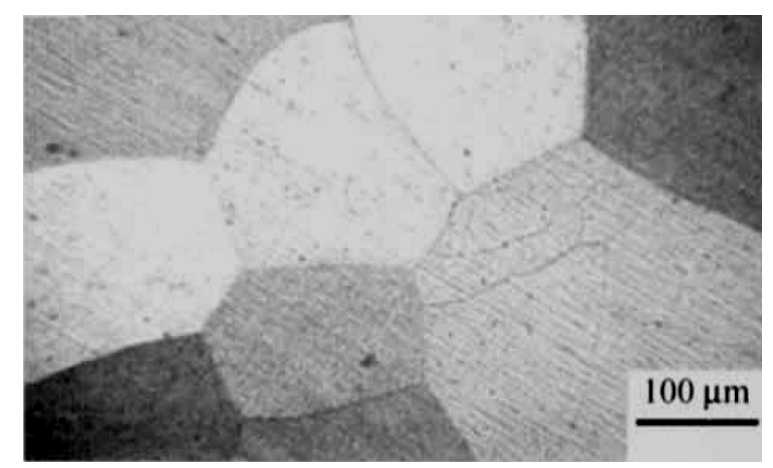

(a)

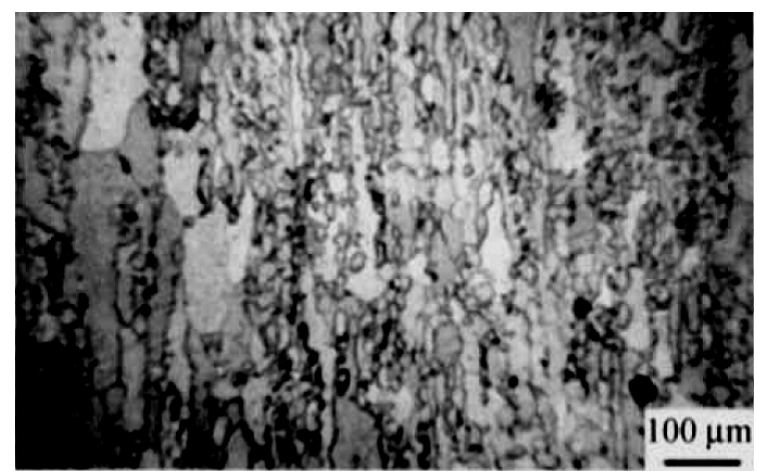

(b)

Figura 2.5: Micrografias em MEV de dois aços AISI 430 estudados por Liu et al. ${ }^{\left({ }^{6}\right)}$ contendo diferentes teores de carbono. (a) $0,03 \%$ de $\mathrm{C}$ e (b) $0,10 \%$ de $\mathrm{C}$.

MacDonald et al. ${ }^{(7)}$ estudaram as variações microestruturais de duas variações comerciais do aço AISI430, sendo uma estabilizada ao Ti e Nb e a outra sem estabilização, com uma máquina de simulação termomecânica acoplada a um medidor sensível da taxa de deformação e com análises via MET. Eles observaram que a precipitação do carbonitreto $\mathrm{Nb}(\mathrm{C}, \mathrm{N})$ seguiu o gráfico da figura 2.6.

Sung et al. ${ }^{(8)}$ estudaram a nitretação a alta temperatura de um aço comercial 
AISI430 (Fe-16,3\%Cr-0,36\%Mn-0,28\%Si-0,04\%C, \% em peso). Na figura 2.7 apresenta-se a micrografia obtida para a condição nitretada a $1100^{\circ} \mathrm{C}$ por $15 \mathrm{~min}$. Observa-se nesta micrografia a presença de dois campos: martensita e (martensita + ferrita). Dado ao tratamento de nitretação ter sido realizado a $1100^{\circ} \mathrm{C}$, pode -se observar na micrografia da figura 2.7(a) a presença de duas martensitas, uma de carbono (canto direito, nos antigos grãos de austenita que coexistem com ferrita a $1100^{\circ} \mathrm{C}$ ) e uma de nitrogênio (canto esquerdo - superfície de nitretação). Esta observação é corroborada pelo gráfico da figura 2.7 (b) onde para a temperatura e tempo de tratamento não se verifica a presença de $\mathrm{N}$ após $160 \mu \mathrm{m}$ de espessura.

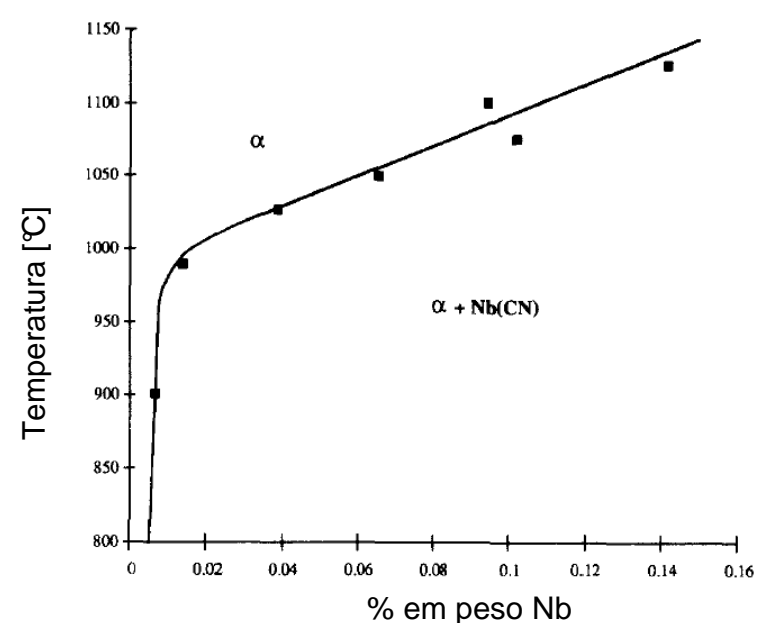

Figura 2.6: Precipitação do carbonitreto $\mathrm{Nb}(\mathrm{C}, \mathrm{N})$ experimental e calculada. Gráfico obtido de (7). (Fe-0,016\%C-0,69\%Mn-0,36\%Si-16,32\%Cr-0,29\%Ni-0,017\%N-0,16\%Nb, \% em peso)

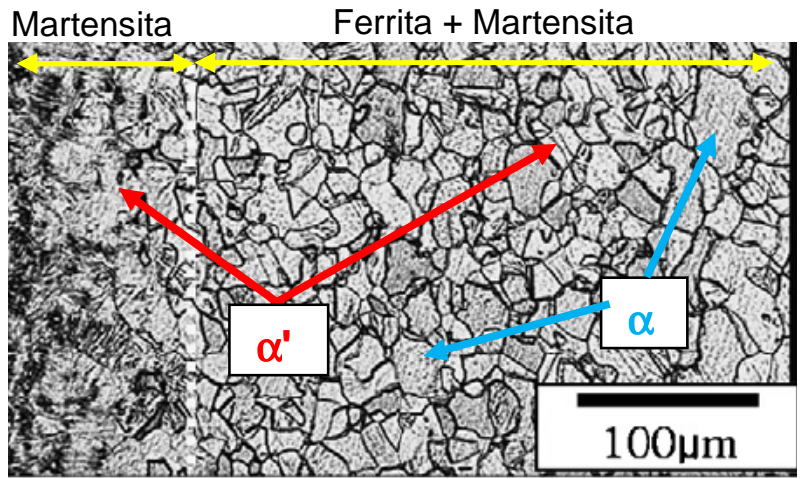

(a)

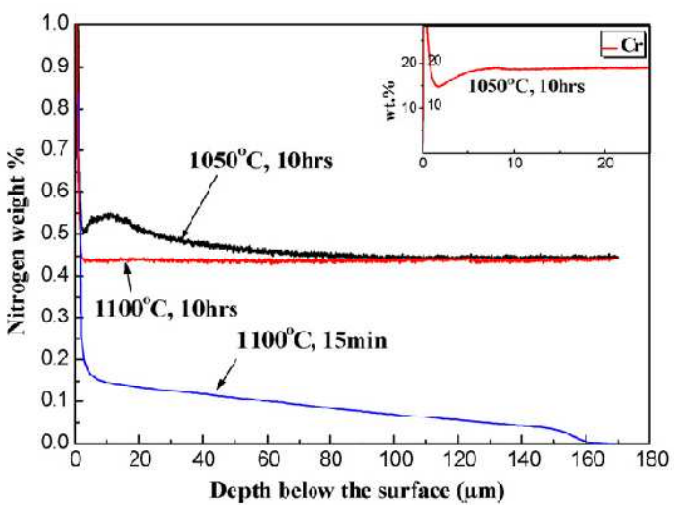

(b)

Figura 2.7: (a) Micrografia em MO do aço AISI430 nitretado a alta temperatura (1100 $\mathrm{C}$ por $15 \mathrm{~min})$, mostrando a presença de ferrita $(\alpha)$ e martensita $(\alpha)$. (b) Variação da concentração de nitrogênio em função da profundidade da amostra. Micrografia e gráfico obtidos de (8).

\subsection{Extração de precipitados}

A literatura apresenta poucas referências sobre o processo de extração de precipitados. Uma das principais referências é o trabalho de Burke ${ }^{(22)}$. Neste 
trabalho é discutida a técnica de extração de precipitados, em ligas de ferro e de níquel, feita com o reagente de Berzelius. Segundo Burke ${ }^{(22)}$, o reagente de Berzelius apresentado é uma modificação feita por Meineke ${ }^{(37)}$ do reagente inicialmente proposto por Berzelius ${ }^{(38)}$. O reagente proposto inicialmente por Berzelius consistia de uma solução de cloreto de cobre II $\left(\mathrm{CuCl}_{2}\right)$ para a dissolução de ferros fundidos e posterior determinação do teor de carbono total. Segundo Berzelius, este reagente dissolve totalmente as fases da matriz e todo o carbono que não está na forma de precipitados, é avaliado através de flocos de carbono nos precipitados. Meineke ${ }^{(37)}$ propôs que fossem adicionados ao reagente proposto por Berzelius o ácido tartárico, cloreto de potássio $(\mathrm{KCl})$ e ácido clorídrico $(\mathrm{HCl})$ para melhorar o tempo de dissolução.

Segundo o trabalho de Burke ${ }^{(22)}$, o reagente de Berzelius (160g de $\mathrm{CuCl}_{2}$, $140 \mathrm{~g}$ de $\mathrm{KCl}, 10 \mathrm{~g}$ de ácido tartárico, $925 \mathrm{~mL}$ de água destilada e $75 \mathrm{~mL}$ de $\mathrm{HCl}$ ) apresenta certa solubilidade de alguns precipitados freqüentemente encontrados nos aços e superligas de $\mathrm{Ni}$. Na tabela 2.2 são apresentadas as insolubilidades destes precipitados no reagente de Berzelius.

Tabela 2.2: Insolubilidade de precipitados no reagente de Berzelius segundo Burke ${ }^{(22)}$.

\begin{tabular}{|c|c|}
\hline Compostos & Insolubilidade (\%) \\
\hline $\mathrm{NbC}_{3} \mathrm{~B}_{4} \mathrm{C}, \mathrm{TiN}, \mathrm{Cr}_{5} \mathrm{~B}_{3}, \mathrm{ZrO}_{2}, \mathrm{CrP}$ & $99 \pm 1$ \\
\hline $\mathrm{Cr}_{23} \mathrm{C}_{6}, \mathrm{Cr}_{3} \mathrm{C}_{2}, \mathrm{TiC}, \mathrm{WC}, \mathrm{TaC}_{\mathrm{VC}} \mathrm{Cr}_{2} \mathrm{~N}$ & $96 \pm 1$ \\
\hline $\mathrm{Cr}_{7} \mathrm{C}_{3},(\mathrm{~W}, \mathrm{Ti}) \mathrm{C}, \mathrm{VN}, \mathrm{Al}_{2} \mathrm{O}_{3}, \mathrm{TiS}_{2}$ & $93 \pm 1$ \\
\hline $\mathrm{W}_{2} \mathrm{C}, 3 \mathrm{Y}_{2} \mathrm{O}_{3} \cdot 5 \mathrm{Al}_{2} \mathrm{O}_{3}, \mathrm{NiO}$ & $90 \pm 1$ \\
\hline $\mathrm{Fe}_{3} \mathrm{C}, \mathrm{MoC}, \mathrm{Mo}_{2} \mathrm{C}, \mathrm{Y}_{2} \mathrm{O}_{3}, \mathrm{La}_{2} \mathrm{O}_{3}, \mathrm{Nd}_{2} \mathrm{O}_{3}$ & $<2$ \\
\hline
\end{tabular}

A solubilidade de alguns precipitados pode ser observada, por exemplo, pela análise da dissolução da matriz do aço API-X80, feita por Ramírez ${ }^{\left({ }^{9}\right)}$. Neste trabalho foi feita a extração de precipitados com uso do reagente de Berzelius, e pouca cementita $\left(\mathrm{Fe}_{3} \mathrm{C}\right)$ foi observada com auxílio da difração de raios- $\mathrm{X}$, como mostra a figura 2.8(a).

Na figura 2.8(a) pode-se observar que este aço apresenta uma quantidade apreciável de cementita, a qual não foi observada no padrão de difração dos precipitados extraídos (figura 2.8(c)). Em algumas micrografias do trabalho de Ramírez podem ser observados pequenos carbonitretos de $\mathrm{Ti}$, como mostrado na figura 2.8(b), que é corroborado pelo padrão de difração. Assim, como foi previsto por Burke ${ }^{(22)}$, o padrão de difração retrata a insolubilidade de $\operatorname{Ti}(C, N)$ no reagente de Berzelius e a solubilidade da cementita. 


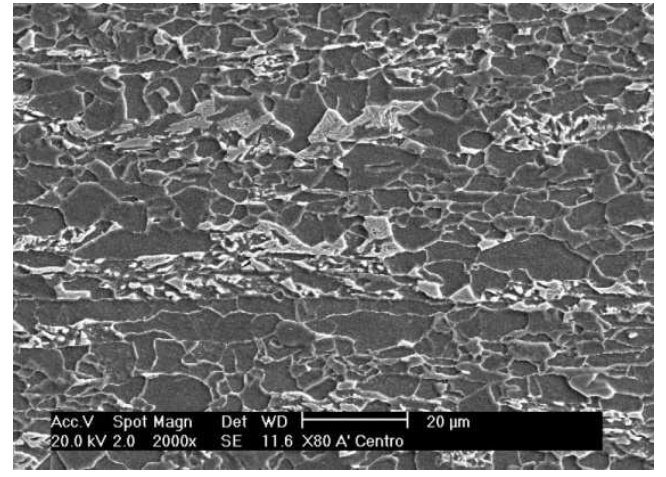

(a)

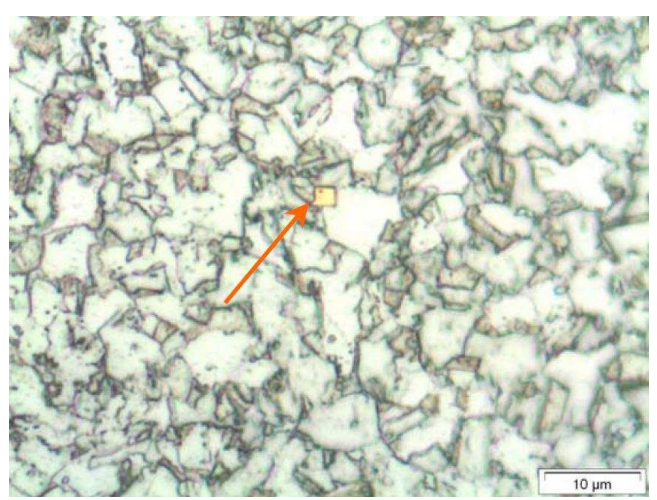

(b)

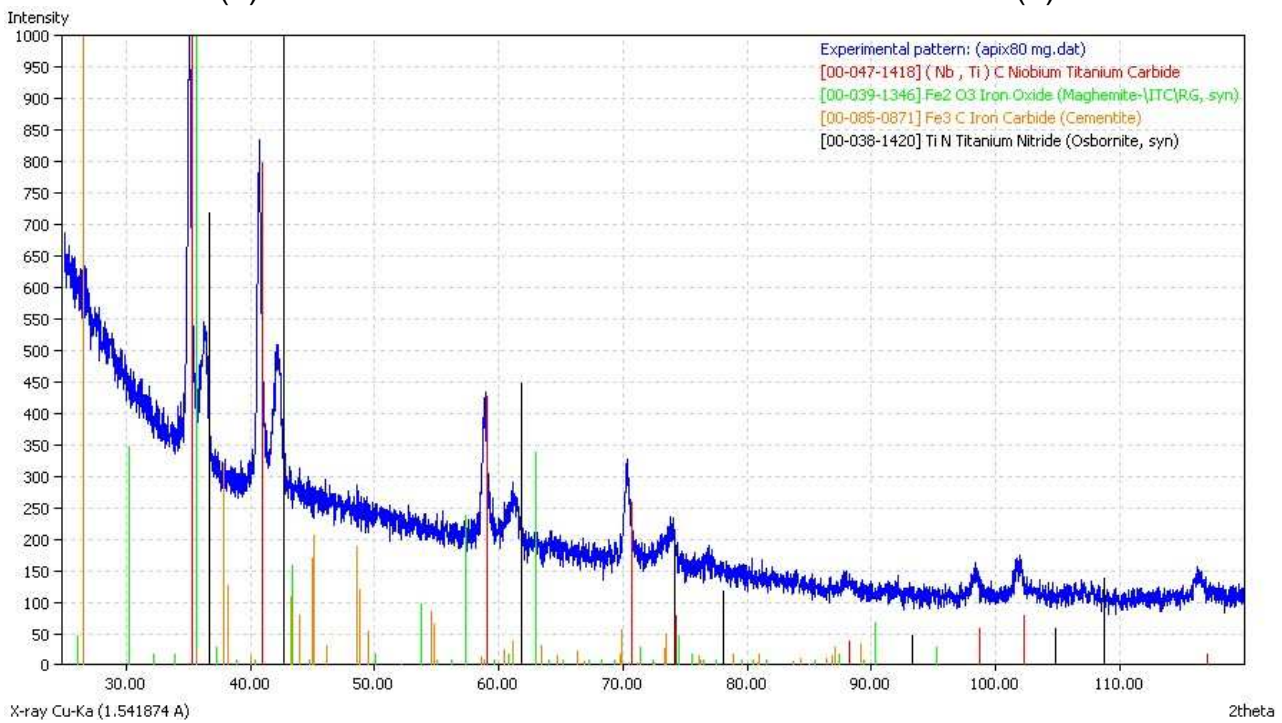

(c)

Figura 2.8: Aço microligado API-X80 estudado por Ramírez ${ }^{(9)}$. (a) Micrografia em MEV mostrando apreciável quantidade de microconstituinte eutetóide contendo cementita. (b) Micrografia em MO do aço API-X80 mostrando a presença de um nitreto de titânio (TiN). (c) Padrão de difração de raios-X (radiação CuK $\alpha$ ) para os precipitados extraídos com uso do reagente de Berzelius.

\subsection{Difração de raios-X}

A técnica de difração de raios-X consiste na incidência de um feixe paralelo de raios-X sobre a superfície de análise de uma amostra e posterior avaliação da interação do feixe incidente com a estrutura cristalina da amostra, isto é, a interação entre o feixe de raios-X e os átomos da estrutura cristalina da amostra. Na figura 2.9 apresenta-se um diagrama esquemático da ótica dos feixes incidentes e refletidos em um difratômetro com geometria Bragg-Brentano ${ }^{(10)}$.

Da figura 2.9 observa-se que da fonte emissora de raios- $X$ (tubo de raios-X) o feixe de raios-X é direcionado pela fenda (slit) do feixe incidente e incide sobre a amostra. $\mathrm{Na}$ amostra o feixe incidente interage com os átomos da estrutura, sendo parcialmente absorvido, e o feixe é refletido, com direção à fenda (slit) do feixe refletido. Da fenda, o feixe segue para o detector, que atua como um contador Geiger, mensurando o número de contagens para cada ângulo de incidência $(\theta)$ do 
feixe incidido na amostra.

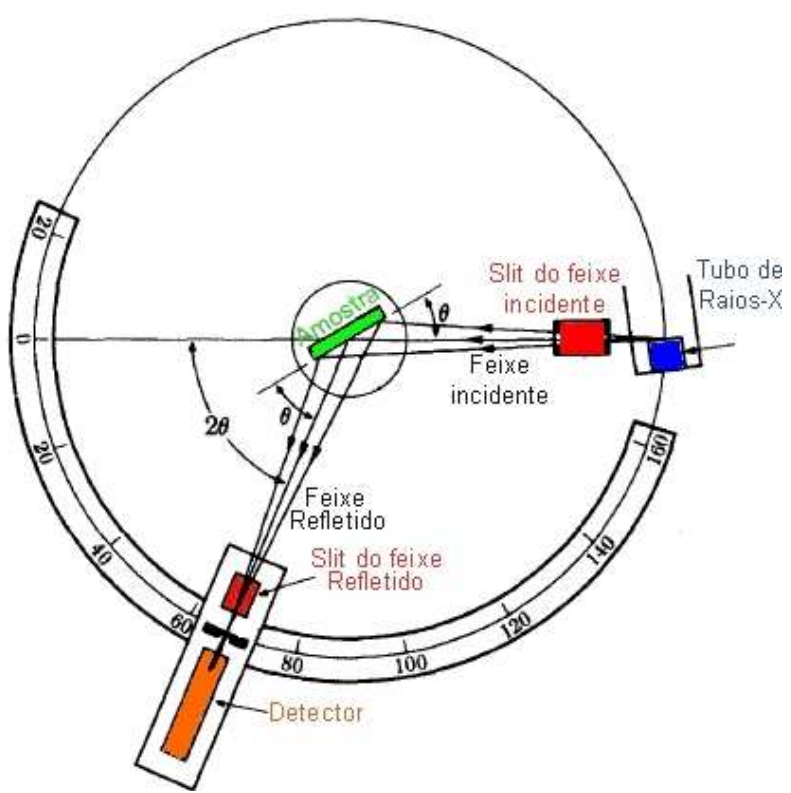

Figura 2.9: Diagrama esquemático do funcionamento de um difratômetro. Adaptado de (10).

Os principais parâmetros de controle de ensaios no difratômetro são:

- o tempo por passo;

- o tempo de coleção;

- o espaço de varredura;

- a corrente e tensão no filamento do tubo.

Os principais parâmetros fixos e inerentes ao equipamento são:

- o tubo de raios-X (cobre, cobalto, cromo, etc);

- os raios primários e secundários (distância do emissor até amostra e distância da amostra até o detector);

- o uso ou não de filtro monocromadores para radiações indesejáveis $\left(\mathrm{K} \alpha_{2}\right.$ e $\left.\mathrm{K} \beta\right)$;

- a possibilidade de varredura múltipla (sistema $X^{\prime}$ Cellerator da Phillips).

A técnica de difração de raios-X baseia-se no fenômeno de interação entre ondas eletromagnéticas. A interação entre as ondas, para ocorrência de difração, pode ocorrer pela mudança na fase das ondas (campo magnético e/ou campo elétrico), pela diferença de intensidades (diferentes fontes, diferentes comprimentos de onda), ou pela diferença de caminhos. A interação entre ondas eletromagnéticas é avaliada através de somas vetoriais, ou seja, dependem da direção, do sentido e do módulo de cada uma das grandezas vetoriais envolvidas (direção, campos elétrico e magnético). 
No caso de uma estrutura cristalina, a difração de raios- $X$ ocorre principalmente pela diferença de caminhos, sendo em parte devida a diferença de comprimentos de onda (radiações $K \alpha_{1}$ e $K \alpha_{2}$ ). Na figura 2.10 apresenta-se um esquema da interação entre o feixe incidente de raios- $X$ e uma amostra cristalina com simetria cúbica simples. Nesta figura observa-se que o ângulo de incidência e de reflexão $(\theta)$ são iguais. O fenômeno de difração se dá pela diferença de caminhos entre o caminho percorrido pela onda incidente e pela onda refletida. Na figura 2.10 a diferença de caminhos está marcada na cor verde, na onda 2 (vermelha). Através de cálculos geométricos simples pode-se obter a lei de Bragg $(n \lambda=2 \cdot d \cdot \operatorname{sen} \theta)$, que relaciona o ângulo de difração $(2 \theta)$ com o espaçamento interplanar (d) para que haja difração de um feixe de ondas qualquer, dado o comprimento de onda $(\lambda)$ do feixe incidente.

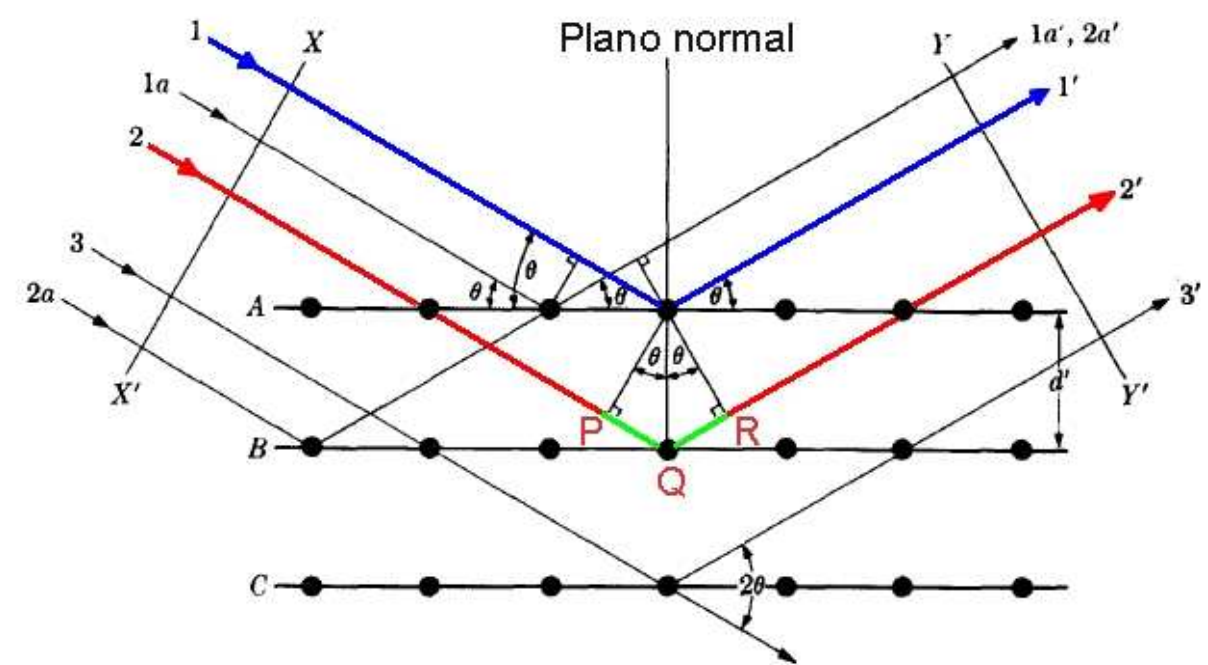

Figura 2.10: Esquema da interação de um feixe de raios- $X$ com uma amostra cristalina com simetria cúbica simples. Figura adaptada de (10).

Embora a lei de Bragg descreva a relação entre o espaçamento interplanar, a radiação utilizada e o ângulo de difração, esta lei nada afirma sobre as intensidades dos picos de difração. Para isso, existem diversos outros fatores que devem ser considerados. Na equação 2.1 apresenta-se a equação da intensidade do feixe difratado, a qual será explica em detalhes a seguir.

$I=\left\|F_{h k l}\right\|^{2} \cdot p \cdot L_{p} \cdot e^{-2 M}$

Equação 2.1

Na equação 2.1, I é a intensidade, $F_{h k l}$ é o fator de estrutura, $p$ é o fator de multiplicidade, $\theta$ o ângulo de difração, $L_{p}$ é o fator de polarização de Lorentz e $M$ é o fator de temperatura. O fator de estrutura é dado pela equação 2.2 , sendo este 
proporcional ao plano cristalino e ao elemento químico presente na fase de interesse.

$$
F_{h k l}=\sum_{1}^{n} f_{n} e^{2 \pi i\left(h u_{n}+k v_{n}+l w_{n}\right)}
$$

Onde $n$ é o número de átomos na célula cristalina, $[h k l]$ é o plano cristalino de interesse, $[u v w]$ é o vetor posição do átomo na célula cristalina e $f_{n}$ é o fator de espalhamento atômico. Esta equação, em células cristalinas contendo mais de uma espécie, deve ser repetida para cada espécie atômica.

O fator de polarização de Lorentz, equação 2.3 , considera os desvios da intensidade devido aos fatores trigonométricos da reflexão do feixe de raios- $X$, de um modo simplificado, o fator de Lorentz considera o alargamento do pico de difração devido a outros ângulos de difração próximos ao principal.

$$
L_{p}=\left(\frac{1+\cos ^{2} 2 \theta}{\sin ^{2} \theta \cos \theta}\right)
$$

O fator de multiplicidade considera o número de átomos para cada plano cristalino que irão refletir/absorver a radiação. Este fator é tabelado, sendo parte da

\begin{tabular}{|c|c|c|c|c|c|c|}
\hline Sistema & \multicolumn{6}{|c|}{ Fator de Multiplicidade } \\
\hline \multirow{2}{*}{ Cúbico } & $h k l$ & $h k l$ & $0 k l$ & $0 k k$ & hhh & $00 l$ \\
\hline & 48 & 24 & 24 & 12 & 8 & 6 \\
\hline
\end{tabular}
tabela apresentada na tabela 2.3 para os sistemas cúbicos.

O fator de temperatura, equação 2.4, considera a vibração atômica dada pela interação do feixe de raios-X com os átomos da rede cristalina.

$$
M=\frac{6 h^{2} T}{m k \Theta^{2}}\left(\phi(x)+\frac{x}{4}\right)\left(\frac{\sin \theta}{\lambda}\right)^{2}
$$

Equação 2.4

Onde $h$ é a constante de Planck, $T$ é a temperatura absoluta, $m$ é a massa atômica do átomo da rede cristalina, $k$ é a constante de Boltzmann, $\Theta$ é a temperatura de Debye, $\phi(x)$ é uma função tabelada para a temperatura de Debye.

A análise de um padrão de difração de raios- $X$, em geral, é feita por comparação entre o padrão experimental e padrões teóricos e experimentais tabelados em um banco de dados ICCD-PDF. No entanto, a comparação se torna difícil caso não exista um padrão tabelado que seja compatível com o padrão experimental obtido. Tal fato ocorre com relativa freqüência devido a inexistência de 
padrões que contemplem a solubilidade de fases, a presença de impurezas, ou mesmo a presença de deformação elástica/plástica na amostra.

A presença destas alterações de composição química ou de estado de deformação elástica/plástica altera o posicionamento, a intensidade e a largura dos picos de difração, de modo que uma simples comparação entre os padrões da literatura e o padrão experimental não são mais possíveis. Para possibilitar a verificação e até quantificação das porcentagens das fases presentes, pode-se utilizar o método de Rietveld.

\subsubsection{Análise de Rietveld}

A análise de Rietveld ${ }^{(39)}$ é um cálculo, baseado no método dos mínimos quadrados, para ajuste de variáveis do equipamento e do material através de um processo iterativo com uso de algum programa dedicado como GSAS ou TOPAS.

Este ajuste consiste em entrar com variáveis do equipamento tais como os tamanhos das fendas (slits), o raio primário e secundário do goniômetro, o tipo de radiação ( $\mathrm{CuK} \alpha$, CoK $\alpha$, etc) com sua partição, a possibilidade de polarização da radiação, entre dezenas de outras variáveis de equipamento. Em paralelo entra-se com as variáveis das fases possíveis tais como a estrutura cristalina (posição dos átomos, parâmetro de rede, grupo espacial, etc.), a possibilidade de textura preferencial, a possibilidade de deformação, tamanho de grão entre outras. Juntando-se as informações do equipamento e do material, o programa combina os dados e calcula um padrão de difração resultante. Através de definições no programa, estipula-se quais são as variáveis de ajuste (otimização) e através de sub-rotinas baseadas no método dos mínimos quadrados, o programa calcula um padrão de difração e o compara ao padrão experimental a cada iteração. Ao final da execução do programa obtém-se um padrão calculado com o respectivo desvio em relação ao padrão experimental.

O ajuste da textura (orientação preferencial) pode ser realizado através de modelos previamente definidos no programa ${ }^{(40)}$. No caso dos aços, um dos modelos mais simples para se trabalhar é o modelo de March ${ }^{(41)}$. Este modelo baseia-se em uma alteração do parâmetro de Lorentz (equação 2.3) de modo a inserir uma probabilidade associada com a orientação preferencial de um ou mais planos cristalinos. Segundo Dollase ${ }^{(41)}$, o modelo de March tem apresentado elevado sucesso para descrição da orientação preferencial encontrada em materiais 
deformados, sejam naturais ou sintéticos. Em especial o modelo de March pode ser aplicado para qualquer geometria cristalina e para qualquer forma de grãos, visto que sua base teórica não apresenta restrições de forma e sua principal base está associada com o mecanismo de rotação de grãos em três dimensões.Outro fator importante é que a integral da equação $2.6 \mathrm{com}$ respeito a $\alpha$ é sempre unitária no intervalo $0<\alpha<\pi / 2$, ou seja, o parâmetro do modelo de March representa uma probabilidade verdadeira.

Basicamente, o modelo de March inclui uma parcela extra na equação 2.1, que torna-se a equação 2.5 .

$I=\left\|F_{h k}\right\|^{2} \cdot p \cdot P_{H}(\alpha) \cdot L_{p} \cdot e^{-2 M}$

Equação 2.5

Na equação 2.5 o fator $P_{H}(\alpha)$ é dado pela equação 2.6.

$P_{H}(\alpha)=\left(r^{2} \cos ^{2} \alpha+\frac{\operatorname{sen}^{2} \alpha}{r}\right)^{-3 / 2}$

Equação 2.6

$\mathrm{Na}$ equação 2.6, $\alpha$ é o ângulo de espalhamento referente ao plano cristalino (hkl) que apresenta orientação preferencial e r é um coeficiente ajustável, que está associado com a probabilidade de ocorrência desta orientação preferencial e com a deformação da amostra.

No entanto, embora o modelo de March apresente as considerações acima feitas, ele interfere significativamente na estimativa da fração de fases devido a sua interferência no cálculo das intensidades dos picos e na largura deles (parcela de Lorentz). Assim, neste trabalho este modelo será apenas utilizado em um caso muito especial onde são verificadas somente duas fases com mesma estrutura cristalina e parâmetros de rede muito próximos. Neste caso, apesar da interferência no cálculo das intensidades dos picos difratados, este modelo permite um melhor ajuste dos dados para determinação do parâmetro de rede destas fases e uma avaliação qualitativa da quantidade das fases.

\subsection{Análise térmica diferencial}

A técnica de análise térmica diferencial (DTA - Differential Thermal Analysis) consiste em medir a diferença de potencial entre dois termopares ligados a um material de referência e a uma amostra em função do tempo e da ciclagem térmica do sistema. O sistema é mantido sob vácuo ou sob atmosfera dinâmica/estática de gases inertes, tais como argônio, hélio ou nitrogênio, dependendo da reatividade da 
amostra e muitas vezes do custo do ensaio. Um esquema de um DTA é apresentado na figura $2.11^{(11)}$.

O material de referência, usualmente alumina ou platina, deve apresentar como propriedades elevada condutibilidade térmica, pouca ou nenhuma expansão térmica e obrigatoriamente não sofrer qualquer tipo de transformação de fases no intervalo de temperaturas no qual o ensaio irá avaliar. Devido a estas propriedades, a variação do coeficiente $C_{P}$ (calor específico a pressão constante) da amostra de referência é praticamente linear em função da temperatura. Como o $C_{P}$ da amostra de referência é linear, pode-se combinar os dados do $C_{P}$ da amostra de referência e do sinal do DTA (diferença de potencial elétrico entre os termopares) em função do tempo e da temperatura e se determinar as temperaturas e as entalpias das transformações de fases da amostra sob análise.

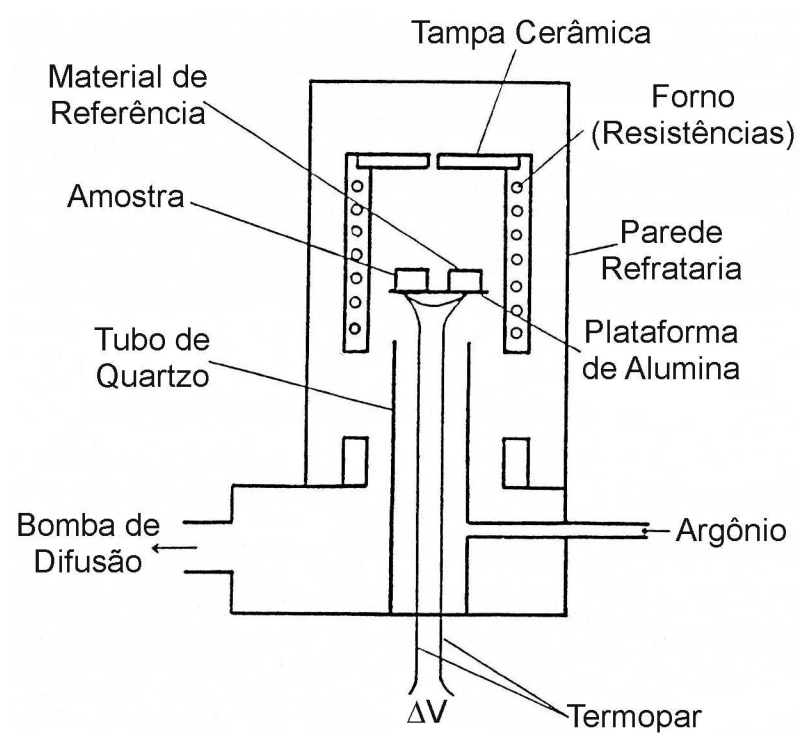

Figura 2.11: Esquema do DTA mostrando as partes do sistema. Figura adaptada de (11).

A determinação da temperatura das transformações de fases a partir do sinal do DTA é em geral feita, determinando-se o ponto de cruzamento das duas tangentes traçadas nos dois lados de uma inflexão da curva. O ponto de cruzamento das tangente determina a temperatura da transformação de fase. Ao aplicar esta técnica em metais puros o erro envolvido na determinação das temperaturas das inflexões é aceitável, visto que é da mesma ordem de grandeza do erro do equipamento ${ }^{(12)}$. Ao se aplicar a técnica das tangentes a ligas, dependendo do sistema, o erro na determinação das temperaturas é muito maior, como pode ser observado na figura 2.12 . 

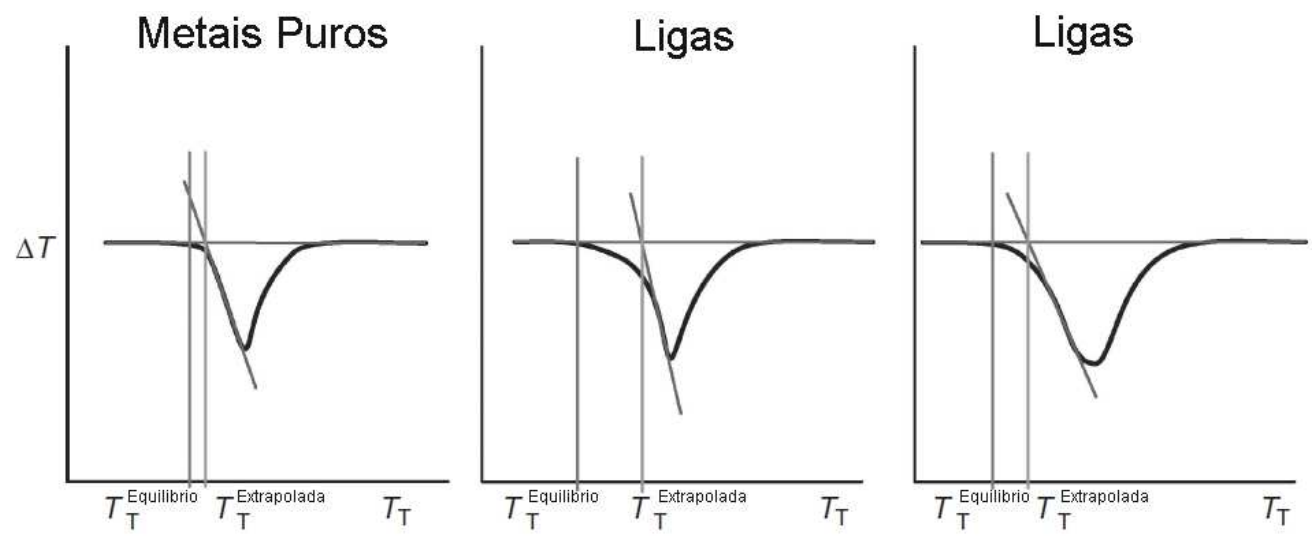

Figura 2.12: Determinação das inflexões do sinal do DTA pela técnica das tangentes. Figura adaptada de (12).

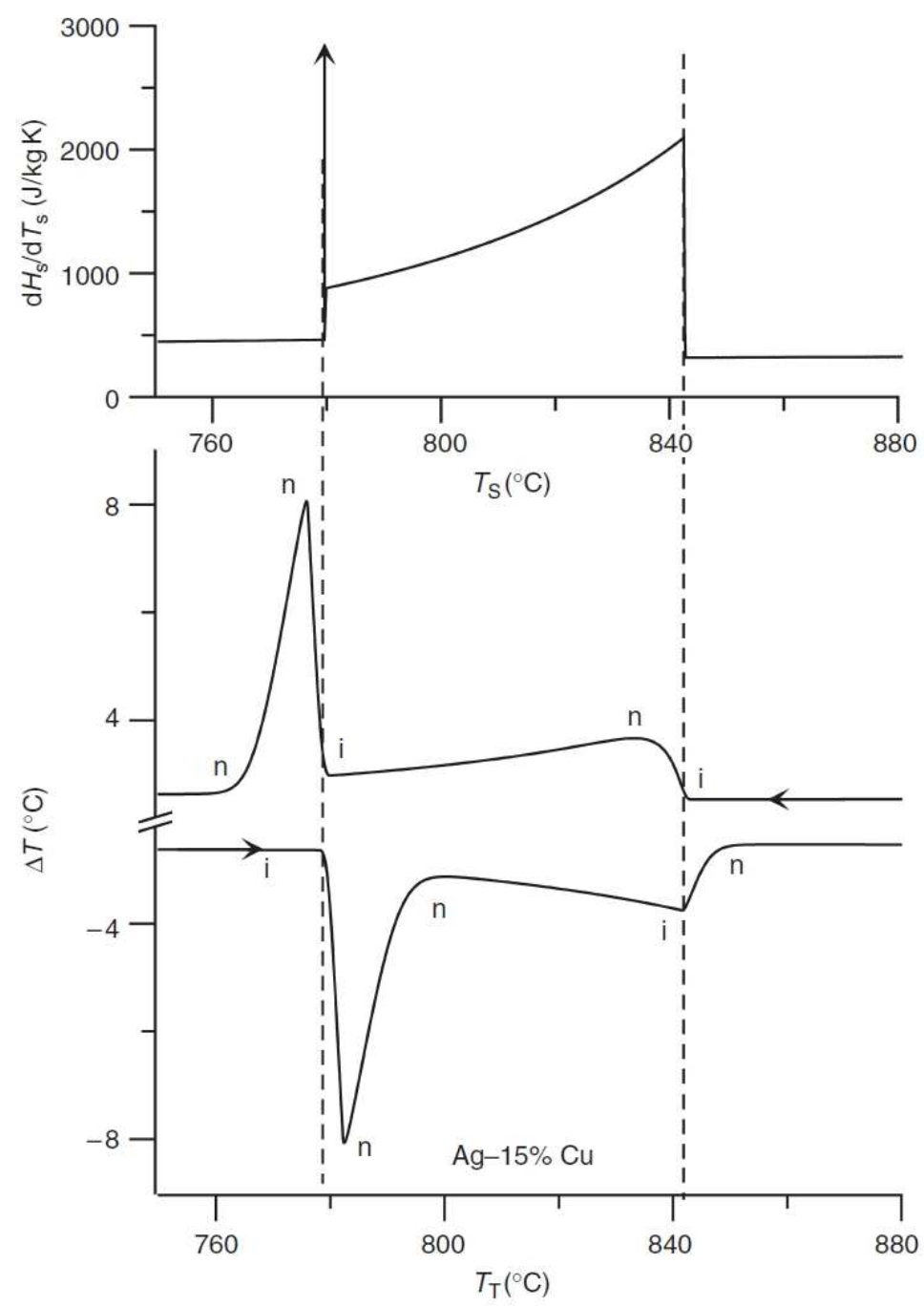

(a)

(b)

Figura 2.13: Diagrama do DTA da liga Cu-15\%Ag (peso) coletado com taxa de aquecimento / resfriamento de $5 \mathrm{~K} / \mathrm{min}$. Determinação das inflexões do sinal do DTA por coleta. Os pontos marcados com "i" indicam as inflexões importantes e os marcados com " $n$ " as inflexões não importantes. Figura extraída de (12).

Existem dois modos simples para se contornar o efeito do erro da técnica das tangentes para a determinação das temperaturas das transformações de fases: através da coleta dos pontos das inflexões manualmente, como indicado na figura 
2.13. Este método permite obter os pontos diretamente do diagrama do DTA, no entanto a precisão dos dados obtidos depende da habilidade em coletar dos pontos do diagrama.

Outra forma para se determinar os pontos das inflexões baseia-se na determinação da curva derivada do sinal do DTA em função da temperatura. Ao se calcular a derivada da curva da entalpia da amostra contra a temperatura, obtém-se a função mostrada nos gráficos das figuras 2.13(a) e 2.14(b). Observa-se que estes pontos correspondem as mudanças das inclinações (derivada) da curva do DTA em função da temperatura. Assim, é possível se correlacionar os pontos da derivada da curva do DTA com respeito a temperatura com a temperatura das transformações de fases da amostra ${ }^{(12)}$.

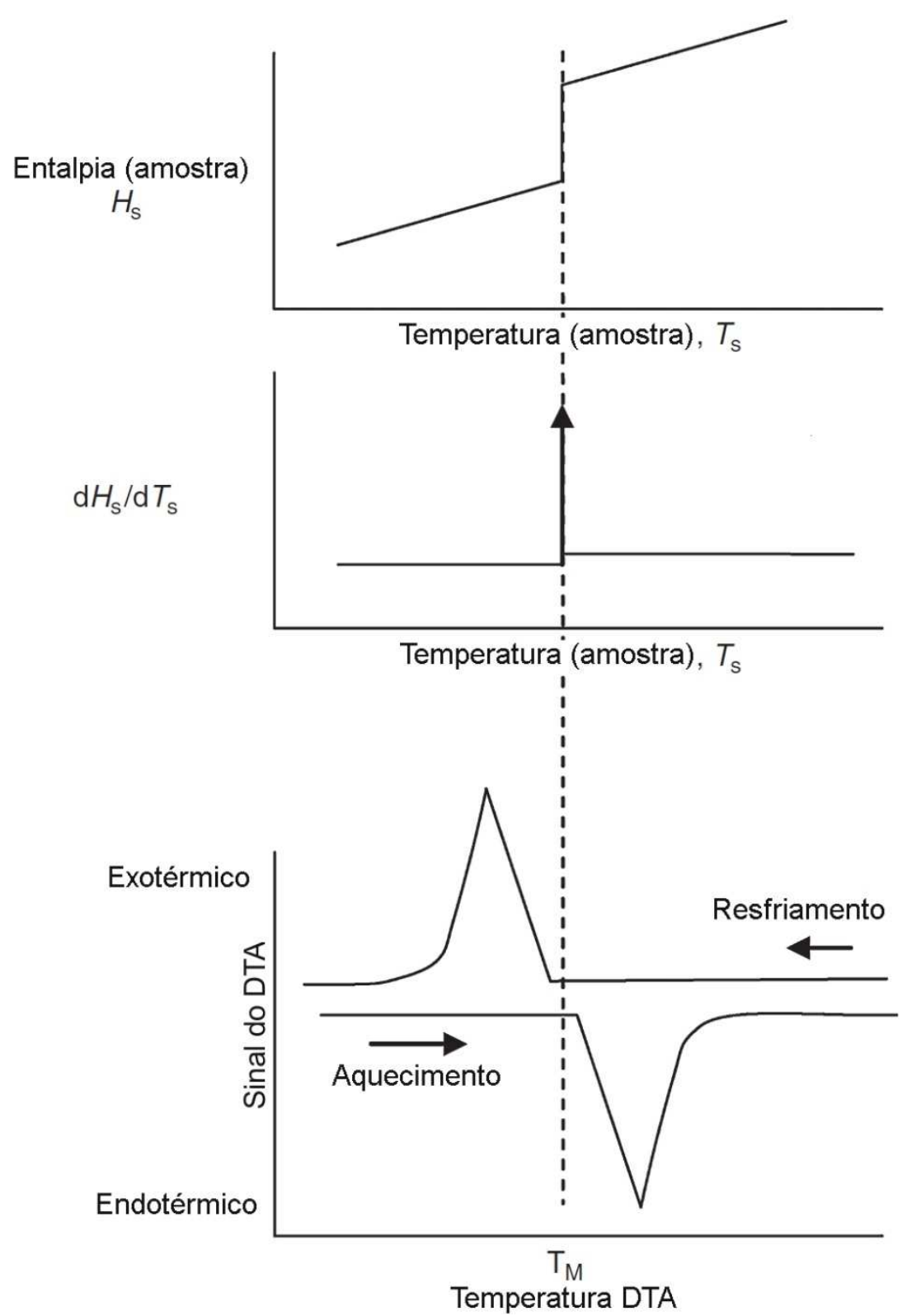

(a)

(b)

(c)

Figura 2.14:. Esquema das relações entre a (a) entalpia da transformação, (b) curva derivada da entalpia com respeito a temperatura (função delta) e (c) o sinal do DTA, a Figura adaptada de (12). 
Considerando que a maioria das transformações de fases não ocorre exatamente na temperatura de equilíbrio devido a necessidade de um superaquecimento ou de um super-resfriamento constitucionais para que ocorra a transformação de fase, a determinação das temperaturas de equilíbrio não pode ser feita diretamente das inflexões da curva do DTA, visto que as temperaturas que são determinadas dependem fortemente da taxa de resfriamento e da cinética das transformações de fases. Isso pode ser observado na figura 2.15 onde é apresentada a influência do número de ciclos térmicos, para uma taxa de aquecimento/resfriamento constantes, sobre a temperatura e a forma dos picos do sinal do DTA o qual foi convertido para energia (entalpia da transformação).

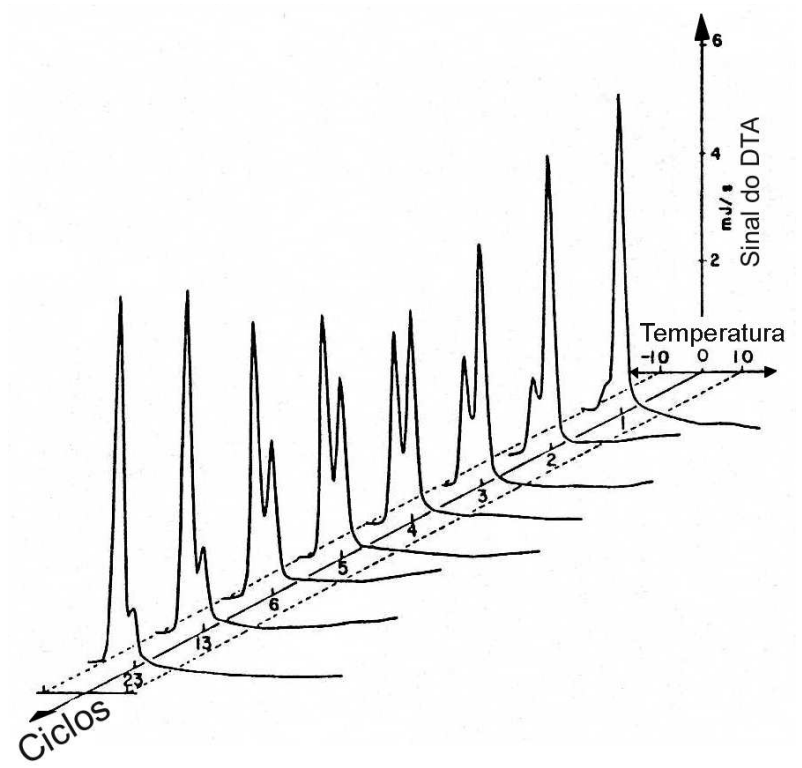

Figura 2.15: Influência da ciclagem térmica, sob taxa de resfriamento/aquecimento constantes, para determinação das temperaturas de equilíbrio em uma transformação exotérmica. Figura adaptada de (13).

Considerando a variabilidade das temperaturas de transformações de fases com a cinética e com as taxas de aquecimento / resfriamento, uma das alternativas para se determinar as temperaturas de equilíbrio das transformações é através da ciclagem térmica com taxas de resfriamento / aquecimento variáveis por ciclos e com valores absolutos decrescentes. Com as temperaturas, de uma dada transformação, determinadas em cada ciclo em função da taxa de aquecimento / resfriamento, é possível se construir um gráfico, com a abscissa sendo a taxa (aquecimento / resfriamento) e a ordenada sendo a temperatura da transformação. Neste gráfico a temperatura de equilíbrio é obtida através da extrapolação dos pontos para a taxa de aquecimento / resfriamento nulas. 


\subsection{Modelagem das transformações de fases}

Existem basicamente duas formas, em geral complementares, para se modelar as transformações de fases: a abordagem termodinâmica e a abordagem cinética. Neste trabalho será apresentada somente a modelagem termodinâmica. Referências a respeito da modelagem cinética em aços inoxidáveis ferríticos podem ser encontradas na literatura $(42 ; 43 ; 44 ; 45 ; 46 ; 47 ; 48)$.

A modelagem termodinâmica baseia-se na determinação das condições do equilíbrio termoquímico de um sistema, a partir da informação de dados como composição, temperatura e pressão. Estes cálculos baseiam-se nos princípios da termodinâmica estatística, a qual surgiu da termodinâmica clássica.

A termodinâmica estatística permitiu durante décadas a avaliação da termodinâmica das soluções até que os modelos estatísticos se tornaram complexos e consistentes o suficiente, que inviabilizaram a aplicação destes sem o uso de máquinas. Em paralelo a este desenvolvimento surgiram os primeiros computadores, os quais possibilitaram a avaliação destes modelos com maior precisão, eficácia e principalmente em tempos plausíveis.

Com 0 advento dos computadores iniciou-se a Termodinâmica Computacional. Esta nova abordagem da termodinâmica estatística permitiu que os cálculos não se restringissem aos sistemas binários e ternários mas pudesse haver a avaliação dos sistemas multicomponentes. Até o advento da termodinâmica computacional os principais modelos multicomponentes baseavam-se nos formalismos de Wagner ${ }^{(49)}$ e de Darken ${ }^{(50 ; 51)}$, e estes eram aplicados somente às soluções diluídas.

Com o surgimento de modelos matemáticos para a descrição dos diversos comportamentos termodinâmicos das soluções, houve a necessidade da criação de metodologias de cálculo e de trabalho experimental que auxiliassem na avaliação destes modelos pelo aspecto físico-químico. Entre as metodologias que se estabeleceram nos principais centros de pesquisa, a que apresenta maior destaque é a metodologia CALPHAD (CALculation of PHAse Diagrams) ${ }^{(52)}$.

A metodologia CALPHAD além de ser um importante conjunto de normas para a avaliação da modelagem termodinâmica também é o nome de uma respeitável revista da área. A metodologia CALPHAD estabelece diversos conceitos para a avaliação dos modelos termodinâmicos quanto a: 
i) obtenção experimental dos dados termoquímicos;

ii) tratamento dos dados experimentais;

iii) desenvolvimento de modelos termodinâmicos;

iv) utilização dos modelos termodinâmicos para descrever os dados experimentais;

v) manter relação entre físico-química dos sistemas e os modelos computacionais;

vi) avaliação da qualidade dos ajustes dos dados experimentais aos modelos.

Segundo estas normas, os dados termoquímicos são selecionados de modo a propiciar a aderência entre os modelos termodinâmicos e a realidade física dos sistemas. Esta metodologia surgiu também como um modo de propiciar a normatização da linguagem entre as diferentes comunidades de pesquisa. Atualmente existem dezenas de programas de cálculos termodinâmicos que executam as funções de cálculos de curvas de energia livre, avaliação da atividade química em sistemas termodinâmicos, previsão de diagramas de equilíbrio, etc. Dentre os principais programas, quatro programas merecem destaque, figura2.16:

i) O programa ThermoCalc (KTH - Suécia);

ii) O programa PANDAT (University of Wisconsin-Madison - EUA);

iii) O programa MTDATA (NPL - Inlgaterra);

iv) O programa FactSage (École Polytecnique de Montreal - Canadá).

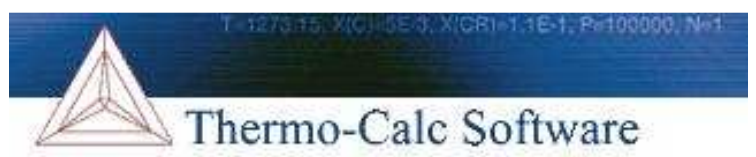

(a)

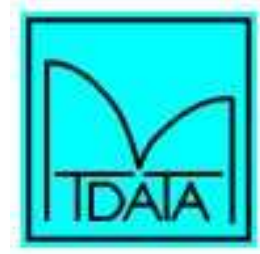

(c)

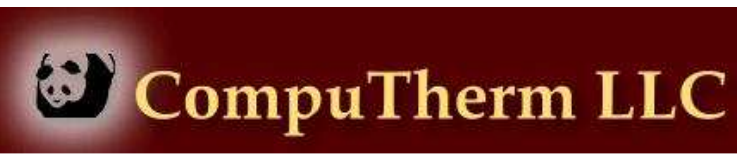

(b)

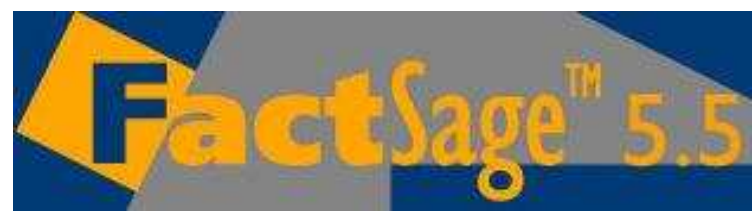

(d)

Figura 2.16: Logotipos dos principais programas de termodinâmica computacional. (a) ThermoCalc, (b) Pandat, (c) MTDADA e (d) FactSage.

Neste trabalho optou-se pelo uso do programa ThermoCalc ${ }^{\circledR}$. Unindo-se o programa ThermoCalc ${ }^{i(3)}$ a um banco de dados termodinâmicos coerente com o sistema de interesse, é possível realizar diversos tipos de cálculos de equilíbrio. Estes cálculos podem ser facilmente conduzidos quando o sistema de interesse é conhecido, isto é, quando as condições de contorno como temperatura, pressão,

\footnotetext{
${ }^{i}$ Neste trabalho opta-se por focar na metodologia de trabalho com o programa ThermoCalc, embora para os demais programas pequenas alterações se façam necessárias.
} 
composição e fases possíveis são bem definidas. No entanto a informação essencial para a realização destes cálculos consiste na correta definição do objetivo do cálculo, o qual nem sempre se encontra totalmente definido. A ausência da correta definição dos objetivos dos cálculos é causada, em geral, pela falta de conhecimento sobre o sistema de interesse, isto é, a termodinâmica computacional é utilizada erroneamente como uma ferramenta para resolver este problema.

Para que seja possível fazer a modelagem termodinâmica de um dado sistema são necessários dois grupos de informações: (a) um banco de dados termodinâmicos com modelos termodinâmicos para descrição das fases de interesse e (b) um programa que execute os cálculos da modelagem. A teoria por trás da modelagem termodinâmica pode ser obtida da literatura ${ }^{(53 ; 52 ; 54)}$ e não será formalmente apresentada neste trabalho, sendo que neste trabalho será apresentada somente uma breve descrição.

Um banco de dados termodinâmicos é composto por um conjunto de linhas de programação que descreve as fases de interesse, cada qual com seu modelo termodinâmico. Pode-se definir um modelo termodinâmico como um conjunto de equações, que possibilitam a descrição matemática das propriedades físicoquímicas de uma dada solução. Os modelos termodinâmicos têm por princípio não selecionar diretamente o comportamento da solução, isto é, possibilitam que o modelador selecione o comportamento de acordo com as propriedades físicoquímicas que a solução apresenta. Os modelos termodinâmicos apresentam equações para os parâmetros termodinâmicos, em geral, na forma de polinômios expandidos por séries de potências, em geral, séries de MacLaurinii.

Os modelos termodinâmicos mais utilizados para a descrição de fases sólidas em aços são baseados no conceito de sub-reticulado. Estes modelos assumem que um reticulado cristalino é composto por diferentes sub-reticulados. Em cada um destes sub-reticulados existem espécies ${ }^{i i i}$ que podem interagir entre si, e pode haver interação entre espécies de sub-reticulados diferentes. Um sub-reticulado, por definição, é um conjunto de locais de uma célula (ou conjunto de células) de um cristal de uma dada simetria, porém pode ser também considerado como um conjunto de átomos/espécies constituindo uma solução líquida. Para cada simetria

\footnotetext{
ii As séries de MacLaurin são equivalentes as expansões pelas séries de Taylor exceto por se fixar $\mathrm{X}_{0}=0$ Assim, os polinômios expandidos por esta série de potências não trazem os fatores inconvenientes dos termos $\left(\mathrm{X}-\mathrm{X}_{0}\right)^{\mathrm{n}}$ que as séries de Taylor apresentam quando da integração ou diferenciação das séries.

iii Espécies podem ser definidas como elementos químicos puros, íons ou compostos de estequiometria definida que fazem parte da descrição de um sistema.
} 
(CFC, CCC, HC, etc.) adota-se um conjunto de sub-reticulados, com um determinado número de sítios em cada um. Como exemplo, cita-se a simetria CFC $\left(A_{1}\right)$ na qual se tem dois sub-reticulados sendo um substitucional e um intersticial. Nestes sub-reticulados adotam-se números de sítios iguais e unitários. No subreticulado substitucional, definem-se as espécies químicas como o $\mathrm{Ni}$, ० $\mathrm{Fe}, \circ \mathrm{Cr}$, etc. No sub-reticulado intersticial agregam-se as espécies como as lacunas, notadas por $\mathrm{Va}$, e espécies como o $\mathrm{C}, \mathrm{N}, \mathrm{H}$, etc. Considerando, como exemplo, a fase austenita $(\gamma)$ presente no sistema Fe-Cr-C, a qual possui estrutura CFC do tipo $A_{1}$, apresenta a seguinte notação: $(\mathrm{Fe}, \mathrm{Cr})_{1.0}(\mathrm{C}, \mathrm{Va})_{1.0}$.

O modelo de sub-reticulados, ou "Compound Energy Model" foi desenvolvido por Hillert, Sundman e Agren em $1981^{(55)}$, e foi inicialmente proposto para efetuar a descrição de soluções sólidas. Posteriormente este modelo foi expandido para a descrição de soluções líquidas, iônicas, etc. O principal diferencial deste modelo foi a introdução do conceito de sub-reticulados e das frações de sítios dos subreticulados. A introdução deste conceito permite que a descrição termodinâmica das fases seja simplificada a uma somatória de compostos limites aos quais se atribui uma energia, isto é, compostos energéticos.

Um composto energético por definição é um composto, real ou não, ao qual se atribui uma energia livre. Este composto é gerado pela definição dos subreticulados e tem propriedades interessantes. A energia livre de uma fase é calculada a partir da energia livre de um composto ou da soma das energias livres de diversos compostos energéticos. Através desta metodologia, pode-se estimar a energia livre de um sistema de ordem $(\mathrm{N})$ a partir da energia livre dos sistemas de ordem (N-1). Através do emprego desta metodologia, pode-se facilmente se obter a energia livre das fases de um sistema multicomponente a partir das descrições de sistemas mais simples (binários, ternários e quaternários).

O processo de cálculo do programa ThermoCalc ${ }^{\circledR}$ inicia-se com a definição dos dados termodinâmicos dos elementos e fases desejados. A definição é realizada através da seleção de um ou mais bancos de dados seguida da escolha dos elementos e fases que constituem o sistema de interesse.

Com a definição das fases e elementos, o programa cria um workspace dedicado à manipulação dos dados termodinâmicos, de acordo com o modelo termodinâmico de cada uma das fases. Como saída, este workspace envia as funções de energia livre das fases e derivadas parciais destas (em função somente 
da composição, temperatura e pressão) ao módulo de cálculo onde estas serão avaliadas por um método próximo ao dos mínimos quadrados ${ }^{(56 ; 57)}$.

A avaliação das funções e derivadas parciais é feita no módulo de cálculo através do estabelecimento de uma malha de composições, e nesta malha são calculados os pontos de menor energia livre de cada uma das fases através da resolução de um sistema de equações diferenciais, ou seja, os "zeros" das derivadas parciais (potenciais químicos dos elementos de mesmo valor nas fases em equilíbrio). Os pontos calculados são salvos em um arquivo que executa a função de gerir dinamicamente a memória ${ }^{(56)}$. Após a avaliação da malha, o equilíbrio do sistema é determinado pelo método das tie-lines e é apresentado ao usuário. É aberta, então, a possibilidade de varrer um ou mais eixos, os quais devem ser obrigatoriamente variáveis definidas como condição inicial do equilíbrio previamente calculado, e seguindo-se o mesmo procedimento descrito para a determinação do equilíbrio os eixos são varridos em função de limites estabelecidos pelo usuário. Após as etapas de cálculos é aberta a possibilidade para extração dos resultados calculados de modo gráfico ou textual.

Através do uso deste programa é possível se obter os seguintes tipos de informações relevantes para a modelagem termodinâmica:

i. Diagramas de equilíbrio de fases;

ii. Mapas de fases para ligas (temperatura versus fração mássica de fases);

iii. Diagramas de Pourbaix (multicomponentes);

iv. Composições das fases em equilíbrio em função da temperatura;

v. Isopletas de equilíbrio (porcentagem de um elemento em função da temperatura);

vi. Seqüência de solidificação com hipóteses de Scheil-Gulliver.

\subsubsection{Aplicações aos aços inoxidáveis ferríticos}

Jin-Cheng et al. ${ }^{(14)}$ estudaram o aço inoxidável ferrítico SUS430 (Fe-0,056C0,25Si-0,30Mn-0,047N-0,02Mo-16,34Cr-0,19Ni-0,03Cu, \% em peso) em altas temperaturas. Como meio de avaliar o equilíbrio termodinâmico, eles utilizaram cálculos com o programa ThermoCalc ${ }^{\circledR}$ aliado ao banco de dados TCFE4. Os diagramas calculados com o programa ThermoCalc ${ }^{\circledR}$, de fração volumétrica de austenita e de ferrita, figura 2.17, foram comparados com os resultados experimentais obtidos por metalografia quantitativa e com resultados de ensaio de 
DSC (Differential Scanning Calorimetry).

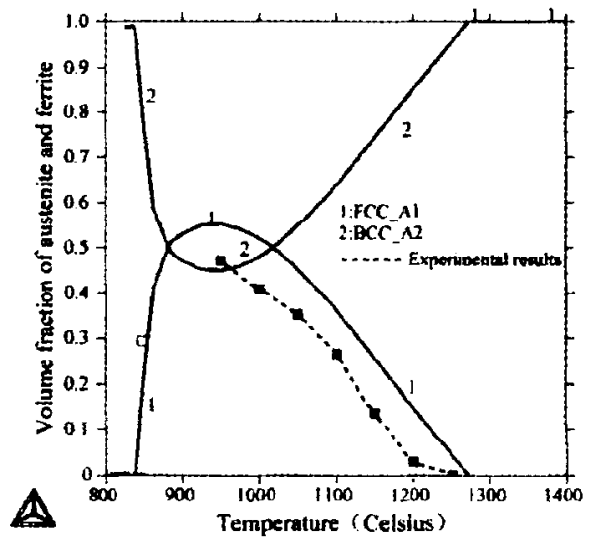

(a)

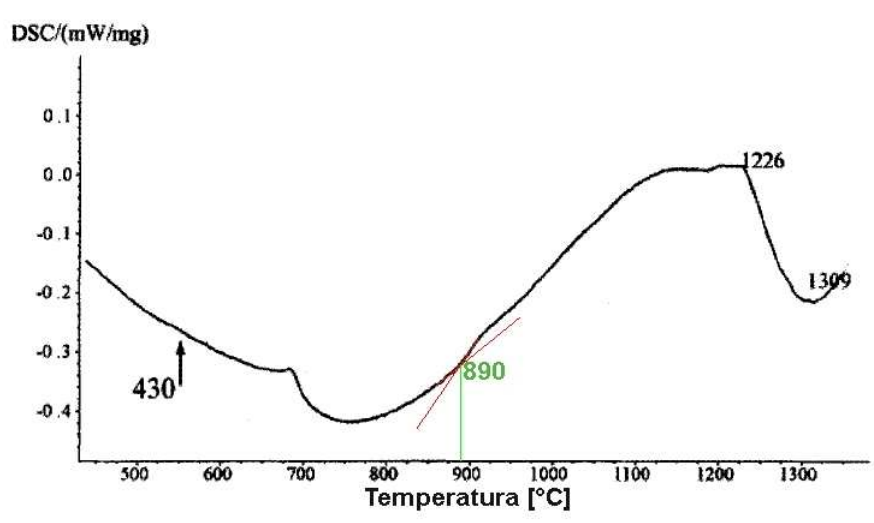

(b)

Figura 2.17: Modelagem termodinâmica do aço SUS430 feita por Jin-Cheng et al. (14) comparada com resultados experimentais de metalografia quantitativa. (FCC_A1 é a austenita, BCC_A2 é a ferrita). (b) Resultados do DSC. Inflexão na curva do DSC não identificada por Jin-Cheng et al. marcada em vermelho.

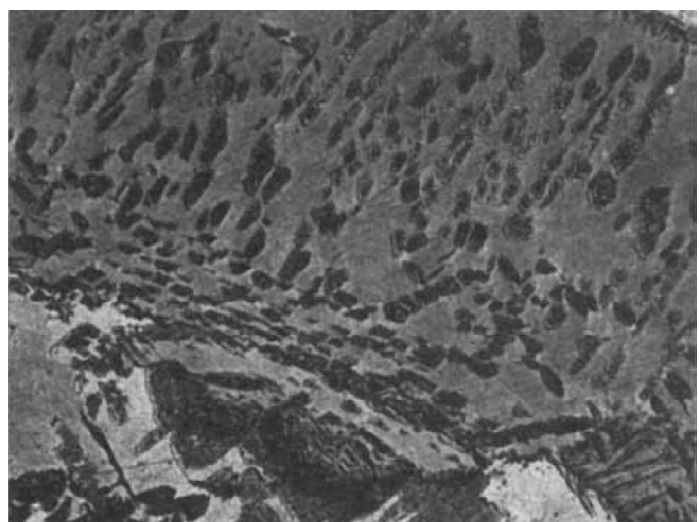

(a) $950^{\circ} \mathrm{C} / 1 \mathrm{~h}$

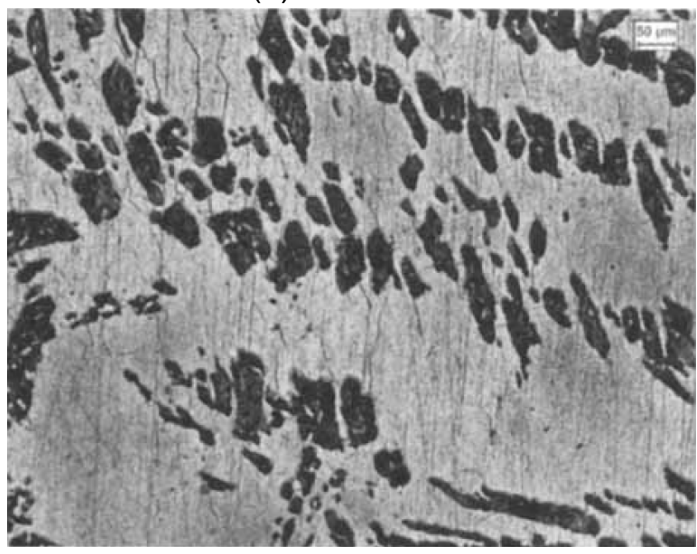

(c) $1050^{\circ} \mathrm{C} / 1 \mathrm{~h}$

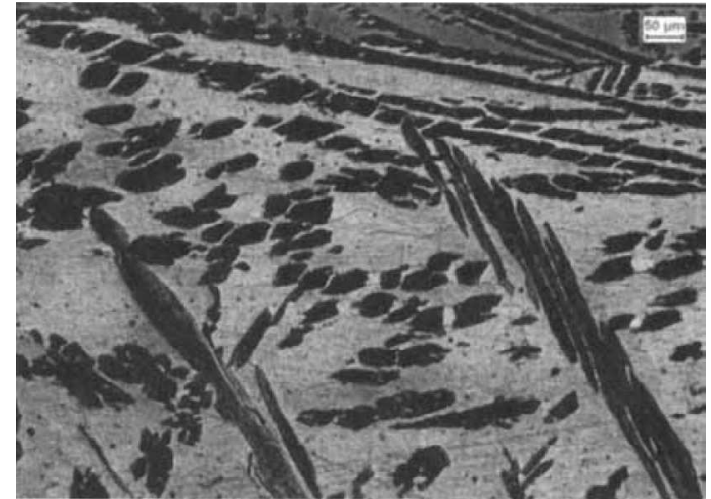

(b) $1000^{\circ} \mathrm{C} / 1 \mathrm{~h}$

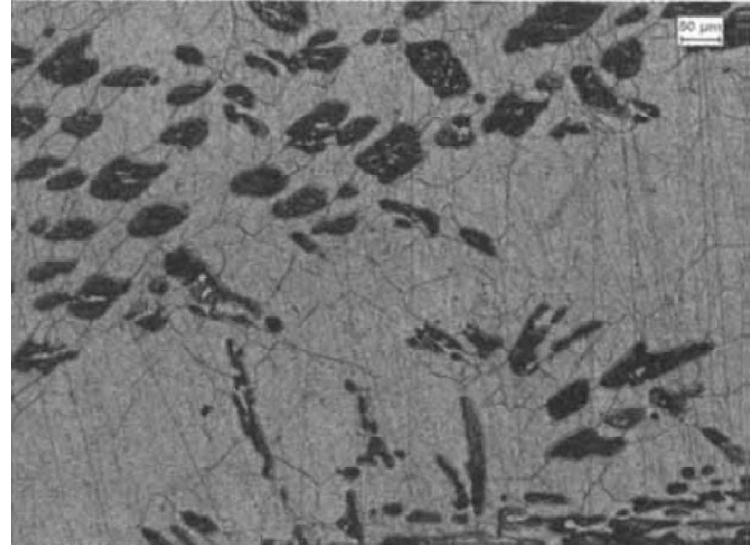

(d) $1150^{\circ} \mathrm{C} / 1 \mathrm{~h}$

Figura 2.18: Aço SUS430 estudado por Jin-Cheng et al. ${ }^{(14)}$ tratado em diversas temperaturas por $1 \mathrm{~h}$ seguido de têmpera em água. Micrografias em MO com ataque por reagente $30 \mathrm{~g} \mathrm{CuSO}_{4}+10 \mathrm{~g}$ $\mathrm{HCl}+60 \mathrm{~g} \mathrm{H}_{2} \mathrm{O}$. (Fase escura é a martensita e fase clara é a ferrita).

No diagrama da figura 2.17(a) observa-se uma boa correlação entre os resultados experimentais obtidos por metalografia quantitativa e os resultados da modelagem com o programa ThermoCalc ${ }^{\circledR}$. Observa-se que 0 aço inoxidável 
SUS430 apresentou cerca de $50 \%$ de fase austenita na temperatura da ordem de $900^{\circ} \mathrm{C}$, onde se pode observar uma inflexão marcada e m vermelho na curva de DSC. A austenita durante o resfriamento rápido foi totalmente convertida na fase martensita, como pode ser observado na figura 2.17, para as amostras do aço SUS430 tratadas a $950^{\circ} \mathrm{C}, 1000^{\circ} \mathrm{C}, 1050^{\circ} \mathrm{C}$ e $1150^{\circ} \mathrm{C}$ po $r$ 1h seguida de têmpera em água.

Podem ser observadas na figura 2.18 a presença de agulhas de Widmansttäten de martensita nos grão ferríticos. A presença destas agulhas indica a presença de austenita em altas temperaturas (entre 900 e $1300^{\circ} \mathrm{C}$ ) e posterior transformação desta austenita em martensita durante a têmpera do material, de modo que observa-se uma estrutura final bifásica (ferrita + martensita).

\subsection{Recristalização e crescimento de grão}

A recristalização dos metais pode ser definida como a reorientação de grãos após a passagem de contornos de alto ângulo. Este fenômeno está fortemente associado com a redução da energia armazenada, principalmente na forma de discordâncias, durante a deformação da rede cristalina. A recristalização ocorre em conjunto com os fenômenos de recuperação e de crescimento de grão. $O$ fenômeno de recuperação refere-se a qualquer outro mecanismo que reduza a energia armazenada pela deformação, sem que ocorra a migração de contornos de alto ângulo ${ }^{(16)}$.

A recristalização, a recuperação e o crescimento de grão não são transformações de fases pela definição clássica, visto que considerando os estados iniciais e finais, não são observadas quaisquer mudanças na composição química ou na estrutura cristalina das fases. No entanto, observa-se que estes são fenômenos passíveis de descrição pelas leis da termodinâmica, uma vez que as energias dos estados iniciais e finais sofrem alterações nos três casos ${ }^{i v}$. Para a recristalização e a recuperação, observa-se a eliminação de defeitos cristalinos, os quais provocam uma redução da energia livre final do sistema. No caso do crescimento de grão observa-se o aumento do tamanho de grão, o que reduz a energia livre de superfície do sistema.

\footnotetext{
iv Embora ocorram alterações na energia livre do sistema, existem poucas técnicas capazes de mensurar estas variações. Como exemplo observa-se que a análise térmica diferencial (DTA) e a Calorimetria Diferencial de Varredura (DSC) não são capazes de avaliar estas alterações, no entanto, alguns experimentos de calorimetria de precisão são capazes de avaliar pequenas alterações.
} 
Embora estes fenômenos não sejam classificados como transformações de fases, eles podem ser descritos através da modelagem usual de transformações de fases baseadas em mecanismo de nucleação e crescimento, ou seja, modeladas pela equação de Johnson-Mehl-Avrami-Kolgomorov (JMAK), equação 2.7. $X=1-\exp \left(-B t^{k}\right)$

A equação JMAK descreve uma curva do tipo sigmoidal onde a constante $B$ pode ser considerada uma constante de velocidade da transformação, $t$ é o tempo, $X$ é a fração transformada e $k$ é uma constante com valores, em geral, entre 1 e 2 para a cinética da recristalização ${ }^{(16)}$.

A recuperação é o primeiro estágio que ocorre no recozimento de um metal deformado. Este termo é aplicado para descrever as mudanças físicas que ocorrem nas regiões não recristalizadas durante o recozimento. A recuperação não apresenta tempo de incubação e a taxa de nucleação decresce com o tempo de recozimento (16). O fenômeno de recuperação não inclui a migração de contornos de grão ou o crescimento dos mesmos.

Segundo Burke e Turnbull ${ }^{(15)}$, a recristalização de um metal deformado pode ser descrita como uma transformação de fases visto que ela pode ser descrita em termos da freqüência de nucleação, e da taxa linear de crescimento. Após um certo tempo de incubação, os grãos isentos de deformação começam a crescer, com um número de sítios de nucleação que aumenta com o tempo, até que eles consumam a matriz inteira. Em geral, a recristalização é descrita por uma curva sigmoidal como apresentada na figura 2.19, (a) para a fração recristalizada e (b) para o tamanho de grão recristalizado $(D)$ após um tempo de incubação $(\tau)$.

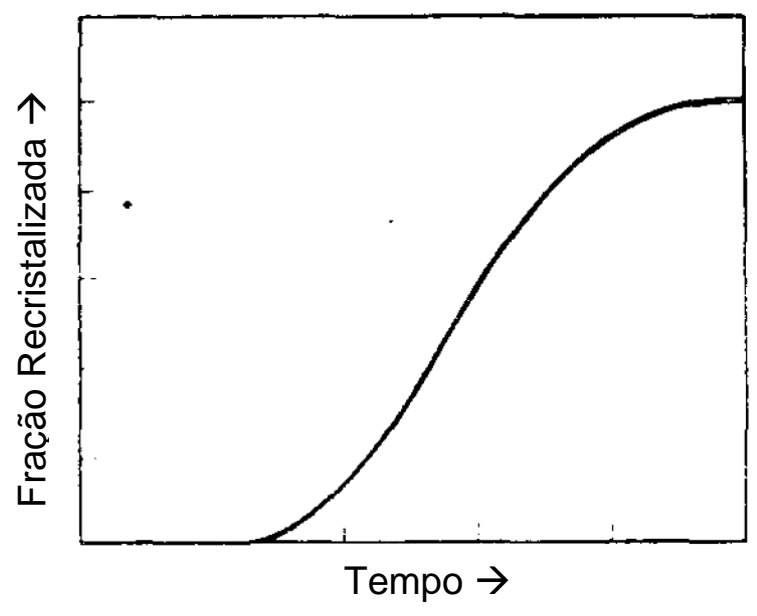

(a)

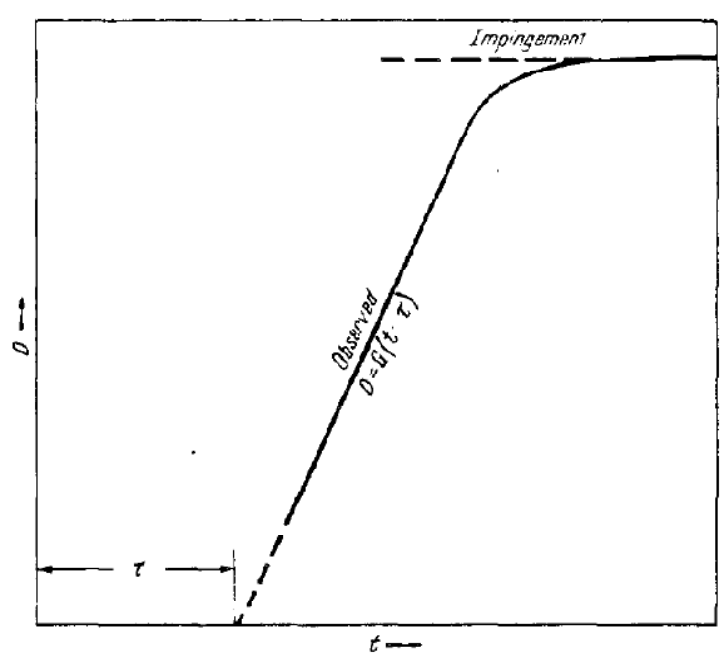

(b)

Figura 2.19: Cinética de recristalização isotérmica. (a) Fração transformada em função do tempo. (b) Tamanho de grão em função do tempo. Figuras extraídas de (15). 
A recristalização pode ser descrita em sete leis as quais foram sintetizadas por Burke e Turnbull ${ }^{(15)}$ em 1952:

1) Uma deformação mínima é necessária para iniciar a recristalização.

2) Quanto menor o grau de deformação da rede cristalina, maior será a temperatura necessária para recristalização.

3) Aumentando-se a temperatura de recozimento o tempo para início da recristalização é diminuído.

4) O tamanho final do grão recristalizado é fortemente dependente do grau de deformação, em menor escala da temperatura de recozimento, sendo menor para o maior grau de deformação e menor temperatura de recozimento.

5) Quanto maior o tamanho de grão inicial, maior será a deformação a frio necessária para que a recristalização ocorra na mesma temperatura e tempo.

6) A quantidade de deformação necessária para ocorrer encruamento aumenta com o aumento da temperatura de deformação.

7) A manutenção do material na temperatura de recozimento após o fim da recristalização produz o crescimento de grão.

Quando a recristalização primária está completa, a estrutura dos grãos ainda não está completamente estável, pois ainda permanece muita energia despendida na forma de contornos de grão. Pela termodinâmica, o estado de mínima energia seria um único monocristal. Assim inicia-se o crescimento de grão (ou a recristalização secundária), cuja força motriz é a redução da energia livre de superfície. Na figura 2.20 observa-se uma estrutura de grãos, com as tendências dos grãos a crescer e de serem consumidos pelo crescimento de grão.

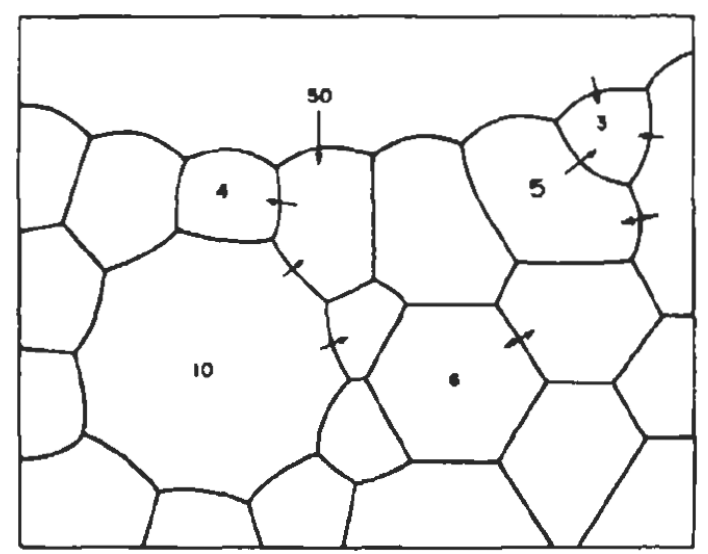

Figura 2.20: Diagrama esquemático do número de lados dos grãos em função da tendência destes a crescer ou serem consumidos pelo processo de crescimento de grão. Figura extraída de (16). 
Burke e Turnbull ${ }^{(15)}$ descrevem o mecanismo de crescimento de grão através da geometria. Segundo eles, um policristal pode ser descrito por um conjunto de poliedros com contatos ao longo das faces, arestas e vértices. Para simplificar o tratamento, eles trabalharam com um plano 2D similar ao apresentado na figura 2.20 onde os contornos de grão estariam sujeitos a tensões superficiais iguais. Na figura 2.21 apresenta-se o mecanismo para a redução do número de lados de grão durante o processo de crescimento de grão.

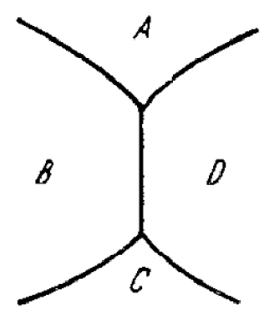

(a)

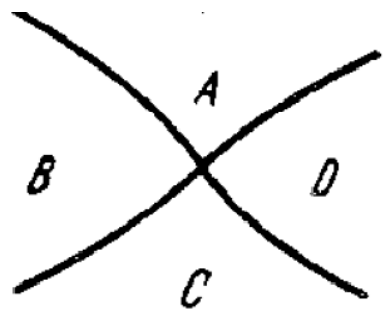

(b)

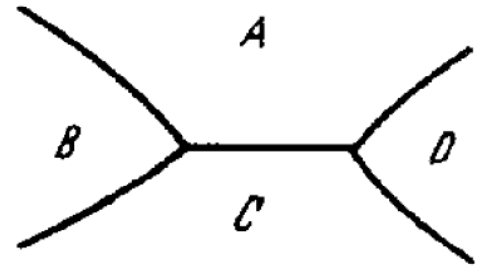

(c)

Figura 2.21: Mecanismo de redução do número de lados de um grão durante o processo de crescimento de grão proposto por Burke e Turnbull. Figuras extraídas de (15).

Como mostrado na figura 2.21, quando quatro grãos se encontram, (a) dois a dois eles apresentam lados comuns. Como resultado, (b) os contornos de grão migram de modo a aproximar os centros de curvatura de modo que os quatro grãos passam a se encontrar em um ponto comum, promovendo o ganho de mais um lado por grão, deixando o sistema instável. A seguir, (c) os quatro grãos se separam de modo que cada grão perde um lado.

Hillert ${ }^{(17)}$ propôs um mecanismo que exemplifica o crescimento de grão através do consumo de grãos com número de lados diferente (5 lados) da média considerada (6 lados). Este mecanismo pode ser observado através da seqüência de figuras (a) até (f) da figura 2.22.

Outro mecanismo utilizado para explicar o crescimento de grão é o mecanismo proposto por Nielsen ${ }^{(18)}$, figura 2.23. Este mecanismo é baseado no coalescimento geométrico dos grãos. Este mecanismo tem baixa probabilidade de ocorrência em estruturas com orientação aleatória de grãos, isto é, em materiais isentos de textura. Considerando que o processo de recristalização, em geral, provoca uma estrutura com orientação preferencial, este mecanismo é, em geral, observado em estruturas recristalizadas. 

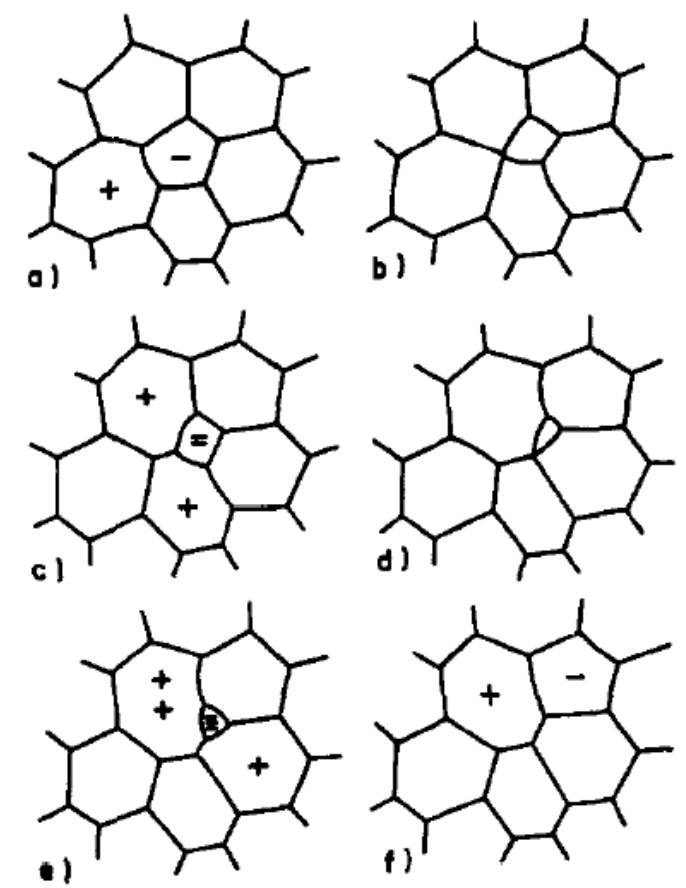

Figura 2.22: Mecanismo de crescimento de grão proposto por Hillert. O sinal de (+) indica os grãos que crescem e o sinal (-) os grãos que estão desaparecendo. Observe que a maioria dos grãos apresentam 6 lados enquanto que o grão que está sendo consumido apresenta 5 lados. Figura extraída de (17).

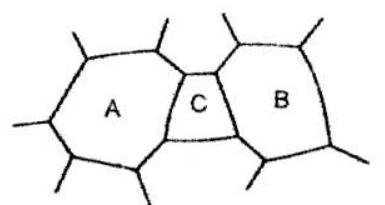

(a)

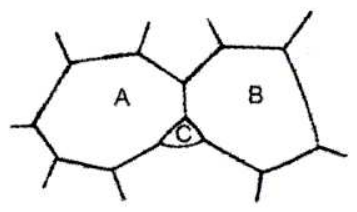

(c)

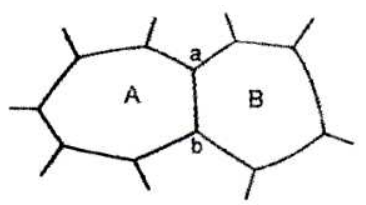

(b)

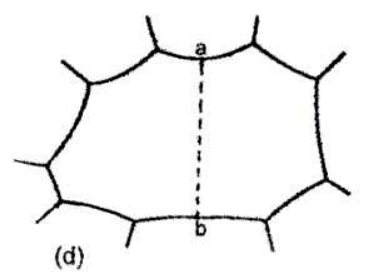

(d)

Figura 2.23: Mecanismo de crescimento de grão proposto por Nielsen, por coalescimento dos grãos. Freqüente em estruturas com textura preferencial. Figura extraída de (18).

\subsubsection{Aplicações aos aços inoxidáveis ferríticos}

Sinclair et al. ${ }^{(19)}$ estudaram a recristalização de aços inoxidáveis ferríticos contendo $12 \% \mathrm{Cr}$ e estabilizados ao Ti (AISI 409 - Fe-0,451\%Si-0,37\%Mn$11,52 \% \mathrm{Cr}-0,182 \% \mathrm{Ti}-0.012 \% \mathrm{C}$ \% em peso). As amostras partiram da condição laminada a frio com diferentes graus de redução (25\%, 50\% e 75\%) e foram avaliadas após recozimento por diferentes tempos a $750^{\circ} \mathrm{C}$. Na figura 2.24 apresenta-se a cinética de recristalização e na figura 2.25 apresentam-se as microestruturas obtidas. 


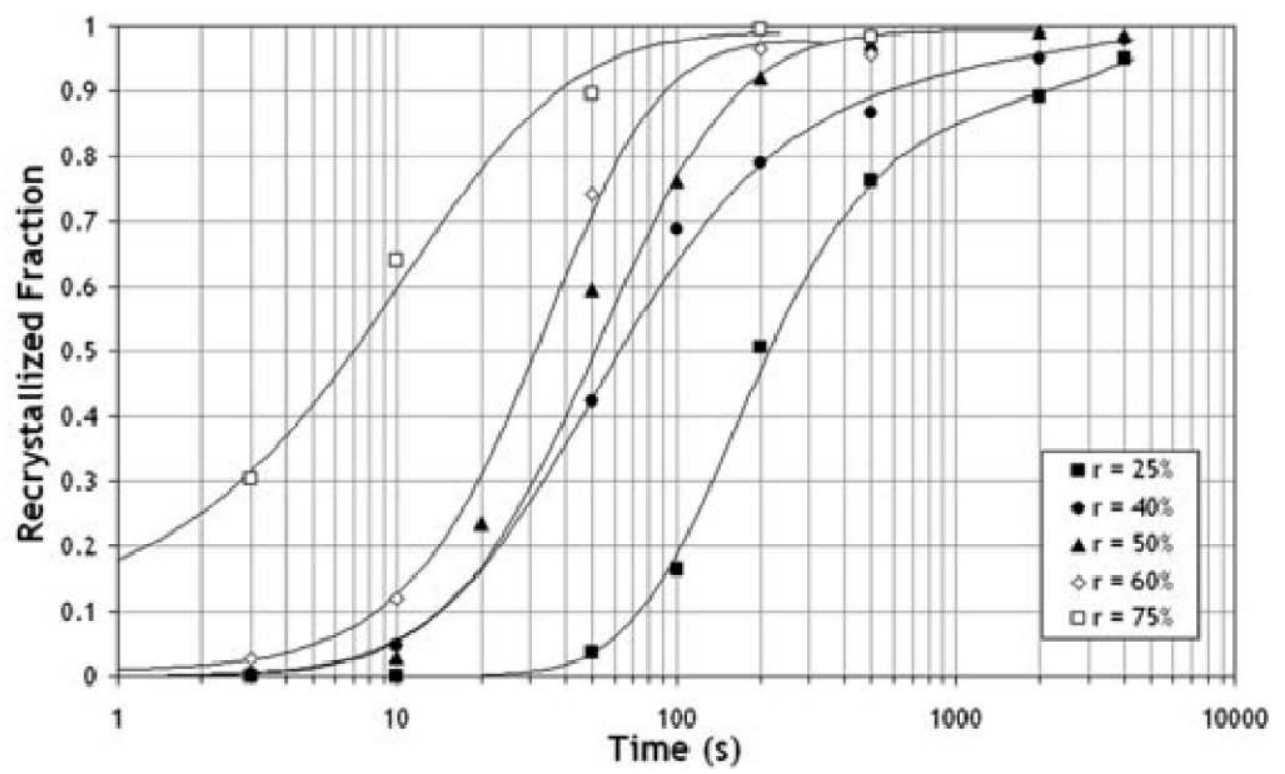

Figura 2.24: Cinética da recristalização do aço AISI 409 recozido a $750^{\circ} \mathrm{C}$ com diferentes graus de redução. Figura extraída de (19).

Observa-se que as curvas cinéticas obtidas por Sinclair et al. ${ }^{(19)}$, figura 2.24, seguem a equação JMAK, bem como estão em perfeito acordo com as leis da recristalização, ou seja, para as maiores deformações o tempo de incubação é menor e a cinética é mais rápida.
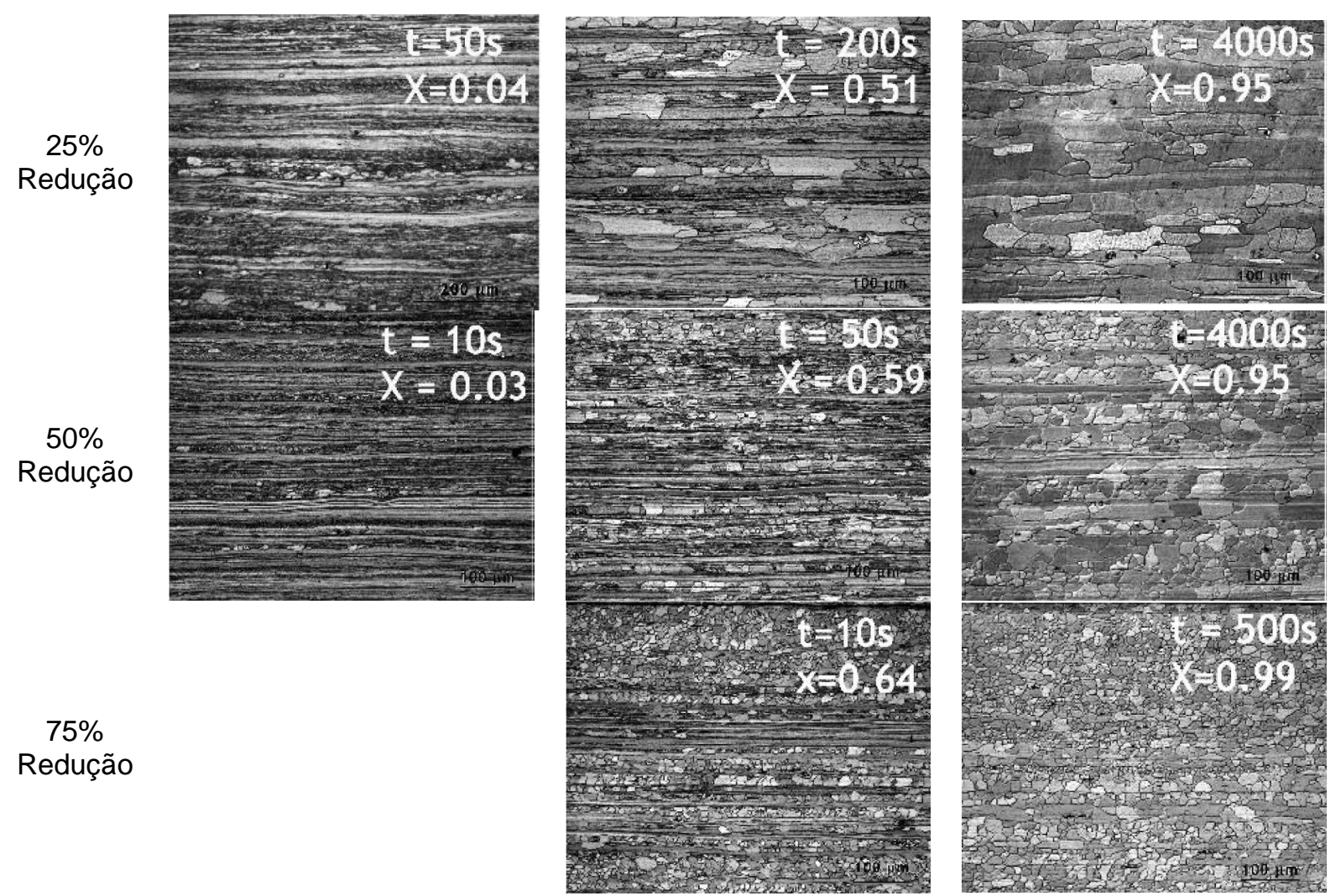

Figura 2.25: Micrografias em MO do aço AISI 409 laminado a frio, com diferentes graus de redução e recozido a $750^{\circ} \mathrm{C}$ por diferentes tempos. Figuras e xtraídas de (19). 
Na figura 2.25 é possível se observar que a recristalização ocorre de modo não homogêneo, com bandas alternadas de regiões recristalizadas e não recristalizadas. Observa-se que com a evolução do processo de recristalização, algumas bandas não recristalizadas persistem sem ocorrência de novos núcleos e ao mesmo tempo bloqueiam a movimentação dos contornos de grão das regiões recristalizadas. Através da análise da textura eles observaram que as regiões recristalizadas correspondem majoritariamente a fibra $\gamma(\{111\}<110>$ ou $\{111\}<112>)$, que é tão mais freqüente quanto maior o grau de deformação a frio. Destas observações eles verificaram que a fibra $\gamma$ apresenta cinética de recristalização mais rápida que a fibra $\alpha(\{001\}<110>$ ou $\{112\}<110>)$.

Weygand et al. ${ }^{(20)}$ avaliaram a recristalização de estruturas deformadas através de simulações cinéticas com a metodologia Vertex. A metodologia Vertex baseia-se na discretização das interfaces dos grãos através da descrição destas pela geometria analítica e posterior simulação. As condições de contorno da simulação baseia-se na entrada de uma microestrutura previamente desenhada e descrita, incluindo-se dados da energia livre de interface, energia para formação de sub-grãos, mobilidade dos contornos de grão/sub-grão, temperatura, etc. Baseados nestes dados de entrada, Weygand et al ${ }^{(20)}$, simularam a microestrutura de um aço após deformação, obtendo a seqüência temporal de microestruturas apresentada na figura 2.26, onde (a) é o estado inicial, (b) é uma fase intermediária e (c) é o estado final, após o término da recristalização.

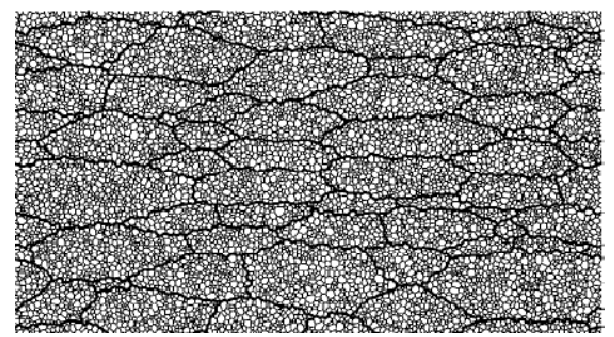

(a)

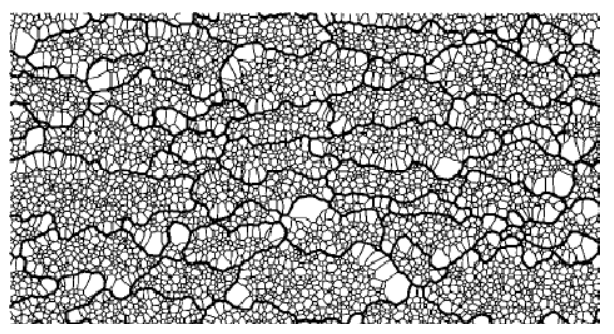

(b)

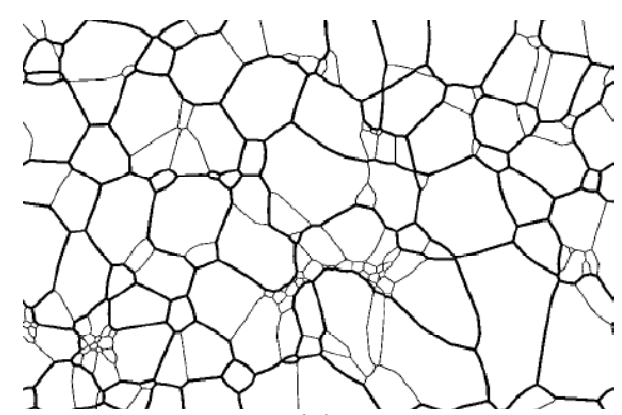

(c)

Figura 2.26: Microestruturas da seqüência temporal da recristalização para uma relação $d / D=0,07$ simuladas por Vertex. (a) é o estado inicial, (b) é uma fase intermediária e (c) é o estado final, após o término da recristalização. Figuras extraídas de (20). 
Weygand et al. ${ }^{(20)}$, estudaram o efeito da relação (d/D) entre o tamanho de grão (D) e o tamanho de sub-grão (d), sendo o tamanho de sub-grão uma variável correlacionada com grau de deformação. Após simulações Vertex, eles obtiveram curvas sigmoidais, figura 2.27, relacionadas com a variação da relação (d/D).

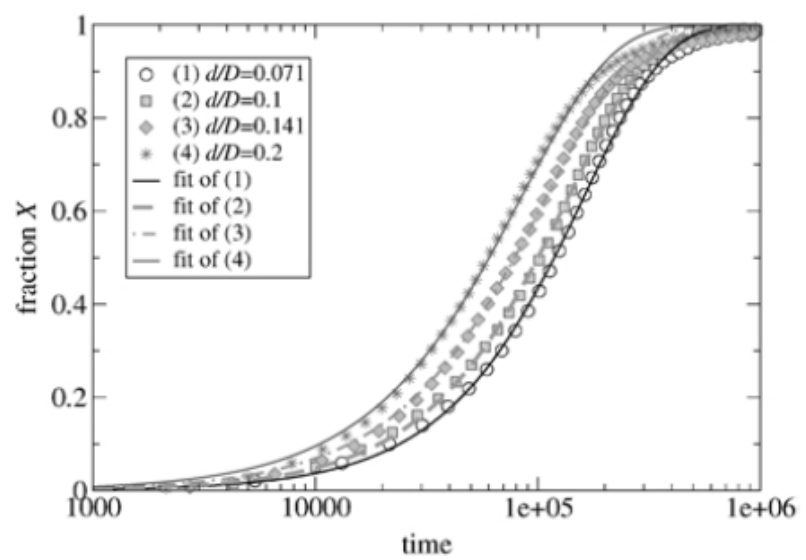

Figura 2.27: Cinética de recristalização calculada por simulação Vertex para variação da relação (d/D) (tamanho de sub-grão / tamanho de grão). Figura extraída de (20).

Na figura 2.27 pode-se observar que quanto maior a relação (d/D), maior o encruamento do material, mais rápida é a recristalização e menor é o tempo de incubação, em acordo com a leis da recristalização. 


\subsection{Objetivos}

Este trabalho visa caracterizar a seqüência de transformações de fases, em especial de precipitação de carbonetos e carbonitretos do aço inoxidável ferrítico AISI 430 convencional.

Como meio de estabelecer a seqüência de precipitação serão utilizadas duas abordagens:

(a) Avaliação pela termodinâmica computacional,

(b) Determinação experimental através de tratamentos térmicos, dilatometria, extração de precipitados, difração de raios- $X$ e metalografia empregando-se microscopia ótica e eletrônica de varredura.

$\mathrm{Da}$ abordagem (a) espera-se avaliar a validade do banco de dados termodinâmicos quando os resultados forem confrontados com os resultados experimentais.

$\mathrm{Na}$ abordagem (b) a prioridade é o estabelecimento da seqüência de precipitação a qual terá sua cinética estimada através de ensaios de DTA. 


\subsection{Materiais e Métodos}

Neste trabalho foram utilizadas amostras do aço AISI 430 convencional na forma de chapas de $4 \mathrm{~mm}$ ou $0,7 \mathrm{~mm}$ de espessura com a composição química apresentada na tabela 4.1 .

Tabela 4.1: Composição química do aço AISI 430 (\% em massa).

\begin{tabular}{|c|c|c|c|}
\hline Elemento & \% em massa & Elemento & \% em massa \\
\hline $\mathbf{C}$ & 0,0458 & $\mathbf{P}$ & 0,0249 \\
\hline $\mathbf{C o}$ & 0,0465 & $\mathbf{S}$ & 0,0026 \\
\hline $\mathbf{C r}$ & 16,007 & $\mathbf{S i}$ & 0,3139 \\
\hline $\mathbf{C u}$ & 0,0145 & $\mathbf{S n}$ & 0,002 \\
\hline $\mathbf{M n}$ & 0,367 & $\mathbf{T i}$ & 0,013 \\
\hline $\mathbf{M o}$ & 0,01 & $\mathbf{V}$ & 0,0419 \\
\hline $\mathbf{N}$ & 0,0497 & $\mathbf{W}$ & 0,0048 \\
\hline $\mathbf{N b}$ & 0,0196 & $\mathbf{N i}$ & 0,165 \\
\hline $\mathbf{F e}$ & Balanço & \multicolumn{2}{|c}{} \\
\hline
\end{tabular}

As amostras do aço AISI 430 convencional foram estudadas em três condições industriais: BQP, BQB e BFB e em 6 condições tratadas termicamente. A amostra BQP refere-se ao aço após laminação a quente, com temperatura final da ordem de $1000^{\circ} \mathrm{C}$ e espessura de $4 \mathrm{~mm}$. A amostra BQB refere-se ao aço BQP recozido a $820^{\circ} \mathrm{C}$ por $40 \mathrm{~h}$ e decapado mecanicamente e quimicamente com espessura final de $4 \mathrm{~mm}$. A amostra BFB refere-se ao aço BQB laminado a frio até espessura de $0,7 \mathrm{~mm}$, recozido a $8^{\circ} 0^{\circ} \mathrm{C}$ e decapado qui micamente.

No item 4.1 serão apresentados os procedimentos utilizados para a caracterização metalográfica das amostras. No item 4.2 serão apresentados os procedimentos utilizados para extração de precipitados. No item 4.3 serão apresentados os conceitos e os procedimentos empregados para a modelagem termodinâmica tanto dos diagramas de equilíbrio dos aços quanto da termodinâmica eletroquímica que está por trás da técnica de extração de precipitados. No item 4.4 apresenta-se 0 procedimento empregado na avaliação dos difratogramas das amostras dos aços. No item 4.5 será apresentado o procedimento dos tratamentos térmicos como forno tubular munido de sistema de vácuo.

\subsection{Caracterização metalográfica}

As amostras foram cortadas com uma cortadeira da marca Struers, modelo Secotom 10, figura 4.1(a), até o tamanho desejado para o embutimento em 
baquelite.

A preparação metalográfica das amostras foi realizada com auxílio de uma politriz automática da marca Büehler, modelo AutoMet 2000, figura 4.1(b).

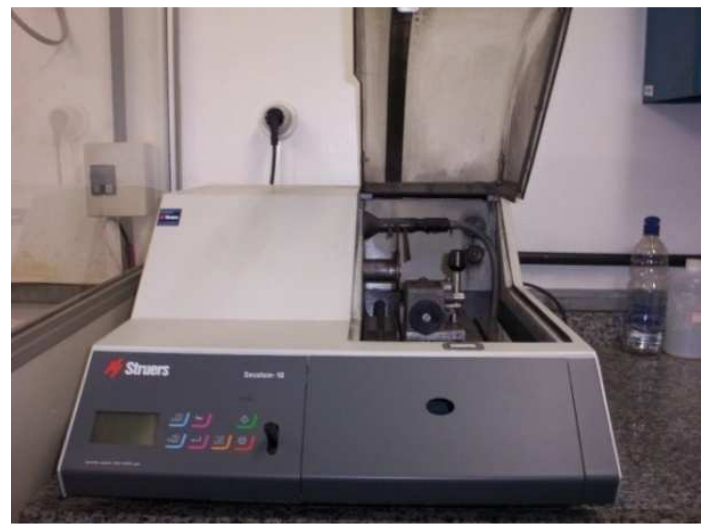

(a)

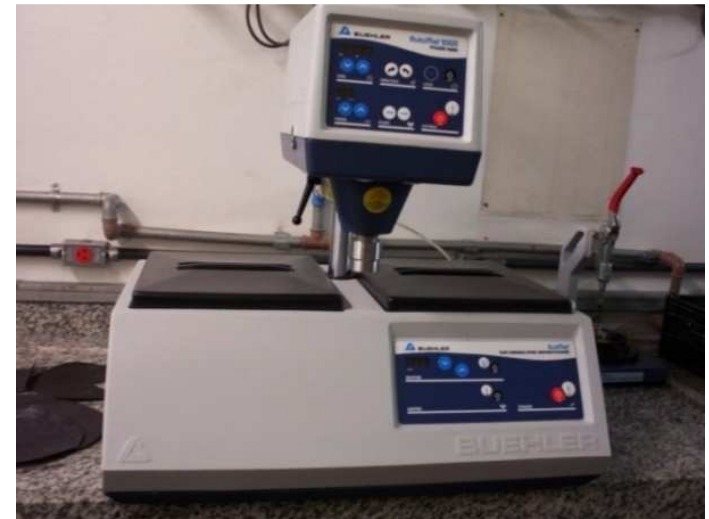

(b)

Figura 4.1: (a) Cortadeira Struers modelo Secotom 10. (b) Politriz automática modelo AutoMet 2000 da Büehler.

As amostras foram lixadas em lixas de papel com partículas de SiC de granulometria 100\# para a quebra dos cantos vivos e obtenção da planicidade. Em seguida foram lixadas em lixas de papel com partículas de $\mathrm{SiC}$ com granulometrias, 180\#, 220\#, 320\#, 400\#, 600\# e 1200\#. Após o lixamento as amostras foram polidas com solução de partículas de diamante de $9 \mu \mathrm{m}, 3 \mu \mathrm{m}, 1 \mu \mathrm{m}$ e solução $\operatorname{deAl}_{2} \mathrm{O}_{3}$ de $0,5 \mu \mathrm{m}$. Na tabela 4.2 são apresentados os dados da programação da politriz.

Tabela 4.2: Dados da programação da politriz utilizada.

\begin{tabular}{|c|c|c|c|c|c|c|}
\hline Etapa & Superfície & Abrasivo & Lubrificante & $\begin{array}{c}\text { Carga } \\
\text { por } \\
\text { amostra }\end{array}$ & Velocidade & Tempo \\
\hline \multirow{7}{*}{ Lixamento } & \multirow{7}{*}{$\begin{array}{c}\text { Lixas de } \\
\text { Papel }\end{array}$} & SiC 100\# & \multirow{7}{*}{$\mathrm{H}_{2} \mathrm{O}$} & $3 \mathrm{lb}$ & 150rpm & $3 \min$ \\
\hline & & SiC 180\# & & \multirow{6}{*}{$5 \mathrm{lb}$} & \multirow{6}{*}{ 280rpm } & \multirow{6}{*}{$2 \min$} \\
\hline & & $\mathrm{SiC}$ 220\# & & & & \\
\hline & & SiC 320\# & & & & \\
\hline & & SiC 400\# & & & & \\
\hline & & SiC 600\# & & & & \\
\hline & & SiC 1200\# & & & & \\
\hline \multirow{4}{*}{ Polimento } & $\begin{array}{c}\text { Disco de } \\
\text { lixamento fino } \\
\text { HERCULES H }\end{array}$ & $\begin{array}{c}\text { Suspensão } \\
\text { de } C_{\text {diam }} 9 \mu \mathrm{m}\end{array}$ & \multirow{3}{*}{$\begin{array}{c}\text { METADI } \\
\text { ou } \\
\text { álcool } \\
\text { etílico }\end{array}$} & $5 \mathrm{lb}$ & 300rpm & $4 \min$ \\
\hline & $\begin{array}{l}\text { Pano de } \\
\text { Polimento } \\
\text { TRIDENT }\end{array}$ & 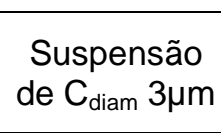 & & $5 \mathrm{lb}$ & 300rpm & $5 \mathrm{~min}$ \\
\hline & $\begin{array}{l}\text { Pano de } \\
\text { Polimento } \\
\text { TRIDENT }\end{array}$ & 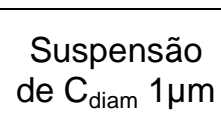 & & $5 \mathrm{lb}$ & 300rpm & $5 \mathrm{~min}$ \\
\hline & $\begin{array}{l}\text { Pano de } \\
\text { Polimento } \\
\text { TRIDENT }\end{array}$ & $\begin{array}{c}\text { Suspensão } \\
\text { de } \mathrm{Al}_{2} \mathrm{O}_{3} \\
0,5 \mu \mathrm{m} \\
\end{array}$ & $\begin{array}{c}\mathrm{H}_{2} \mathrm{O} \\
\text { destilada }\end{array}$ & $5 \mathrm{lb}$ & 300rpm & $5 \min$ \\
\hline
\end{tabular}


O ataque metalográfico, quando realizado, foi feito com os reagentes apresentados na tabela 4.3.

Tabela 4.3: Reagentes para os ataques metalográficos ${ }^{(1)}$.

\begin{tabular}{|c|c|l|}
\hline Reagente & Composição & \multicolumn{1}{c|}{ Utilização } \\
\hline Vilella & $\begin{array}{c}1 \mathrm{~g} \text { ácido pícrico, } 5 \mathrm{~mL} \mathrm{HCl}, \\
100 \mathrm{~mL} \text { etanol }\end{array}$ & $\begin{array}{l}\text { Uso a temperatura ambiente até 1min. } \\
\text { Delineia partículas de segundas-fases } \\
\text { (carbonetos, fases } \sigma \text { e } \delta \text { ). Pode ser } \\
\text { armazenado. }\end{array}$ \\
\hline Kalling's 1 & $\begin{array}{c}1,5 \mathrm{~g} \mathrm{CuCl}_{2}, 33 \mathrm{~mL} \mathrm{HCl}, 33 \mathrm{~mL} \\
\text { etanol, 33mL H} \mathrm{O}\end{array}$ & $\begin{array}{l}\text { Colore a ferrita, martensita na cor preta, } \\
\text { austenita não é atacada. Uso em temperatura } \\
\text { ambiente. Pode ser armazenado. }\end{array}$ \\
\hline Kalling's 2 & $\begin{array}{c}5 \mathrm{~g} \mathrm{CuCl}_{2}, 100 \mathrm{~mL} \mathrm{HCl}, \\
100 \mathrm{~mL} \text { etanol }\end{array}$ & $\begin{array}{l}\text { Uso a temperatura ambiente. Ataca a ferrita } \\
\text { rapidamente, a austenita levemente a não } \\
\text { ataca carbonetos. Pode ser armazenado. }\end{array}$ \\
\hline
\end{tabular}

\subsection{Extração de precipitados}

O procedimento experimental da técnica de extração de precipitados é constituído de sete etapas: corte das amostras, limpeza das amostras, preparação da solução, dissolução das amostras, filtração a vácuo, secagem do filtrado e análise do filtrado em MO e DR-X.

As amostras foram cortadas, com auxílio da cortadeira Struers (figura 4.1(a)), em pequenos pedaços de dimensões da ordem de $5 \mathrm{~mm} \times 5 \mathrm{~mm} \times(4 \mathrm{~mm}$ ou $0,7 \mathrm{~mm})$. A limpeza das amostras consistiu na lavagem destas em banho de álcool etílico $(96,89$ por 30min sob ultra-som.

A dissolução das amostras foi feita com uso do reagente de Berzelius. Foi utilizado $1000 \mathrm{~mL}$ de solução e cerca de $20 \mathrm{~g}$ de amostra. Na tabela 4.4 é apresentada a composição química do reagente utilizado.

Tabela 4.4: Composição química do reagente utilizado para dissolução.

\begin{tabular}{|l|l|}
\hline Reagente & Composição Química da solução \\
\hline Berzelius & $\begin{array}{l}160 \mathrm{~g} \text { de } \mathrm{CuCl}_{2}, 140 \mathrm{~g} \text { de } \mathrm{KCl}, 10 \mathrm{~g} \text { de ácido tartárico, } 925 \mathrm{~mL} \text { de água destilada e } \\
75 \mathrm{~mL} \text { de } \mathrm{HCl}\end{array}$ \\
\hline
\end{tabular}

Após a dissolução das amostras, as soluções foram filtradas a vácuo. $O$ sistema de filtração utilizado, apresentado na figura 4.2, é constituído por: (1) Funil do tipo Millipore, (2) Conjunto placa porosa + Entrada da linha de vácuo, (3) Membrana de teflon de 0,1 $\mu \mathrm{m}$, (4) placa porosa de vidro, (5) Garra e (6) Frasco Kitassato. O vácuo foi criado a partir de um medidor do tipo Venturi conectado a linha de água e ao frasco Kitassato. 


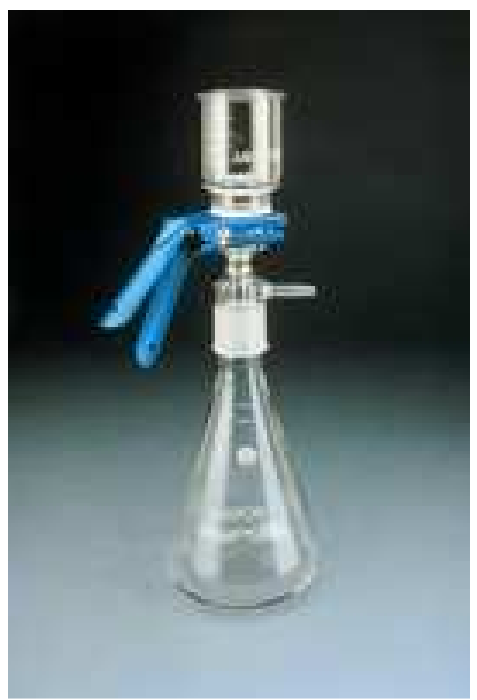

(a)

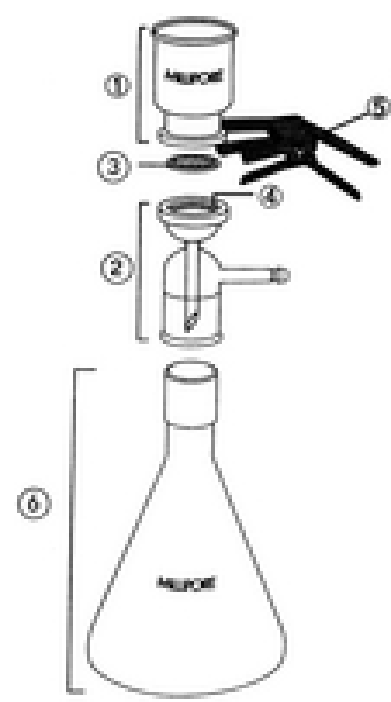

(b)

Figura 4.2: Sistema de filtração utilizado. (a) Visão geral do sistema de filtração. (b) Visão expandida do sistema de filtração indicando as partes do sistema: (1) Funil do tipo Millipore, (2) Conjunto placa porosa + Entrada da linha de vácuo, (3) Membrana de teflon de 0,20um, (4) placa porosa de vidro, (5) Garra e (6) Frasco Kitassato.

Como a membrana de teflon utilizada não é permeável à água, esta foi lavada antes do processo de filtração em álcool etílico $(96,8)$, de modo a torná-la permeável. A filtração durou cerca de 30 minutos por amostra. Após a filtração, os precipitados foram lavados em água e álcool ainda dentro do funil do tipo Millipore e em seguida foram secos ao ar por $24 \mathrm{~h}$. Os filtrados secos foram analisados por difração de raios-X e $\mathrm{MO}$.

$\mathrm{Na}$ tabela 4.5 é apresentada uma lista dos ensaios de dissolução realizados no aço AISI 430.

Tabela 4.5: Lista de ensaios de extração de precipitados realizados no aço AISI 430.

\begin{tabular}{|c|c|}
\hline \multirow{4}{*}{ Condições } & BQP (como recebida) \\
\cline { 2 - 3 } & $\mathrm{BQB}$ (como recebida) \\
\cline { 2 - 3 } & $\mathrm{BF}$ (como recebida) \\
\cline { 2 - 3 } & $\mathrm{BQB}+$ Tratamento Térmico a $600^{\circ} \mathrm{C} / 5 \mathrm{~h}$ \\
\cline { 2 - 3 } & $\mathrm{BQB}+$ Tratamento Térmico a $700^{\circ} \mathrm{C} / 5 \mathrm{~h}$ \\
\cline { 2 - 3 } & $\mathrm{BQB}+$ Tratamento Térmico a $800^{\circ} \mathrm{C} / 5 \mathrm{~h}$ \\
\cline { 2 - 3 } & $\mathrm{BQB}+$ Tratamento Térmico a $900^{\circ} \mathrm{C} / 5 \mathrm{~h}$ \\
\hline & $\mathrm{BQB}+$ Tratamento Térmico a $1000^{\circ} \mathrm{C} / 5 \mathrm{~h}$ \\
\hline
\end{tabular}

\subsection{Modelagem termodinâmica}

A modelagem termodinâmica, por se tratar de uma técnica que produz dados que pode influenciar a análise dos demais resultados experimentais, esta foi realizada somente após o fim das análises experimentais, de modo a não gerar influências nas análises dos resultados, especialmente na interpretação dos padrões 
de difração e obtenção dos pontos experimentais do DTA.

Os diagramas de equilíbrio de fases para a composição química específica do aço foram calculados com o programa ThermoCalc ${ }^{\circledR(3)}$ aliado ao banco de dados termodinâmicos TCFE2 ${ }^{(58)}$. Nos cálculos realizados, os elementos $\mathrm{Sb}, \mathrm{Pb}, \mathrm{Sn}$ e $\mathrm{Zr}$ foram desconsiderados dada a inexistência de suas descrições termodinâmicas no banco de dados utilizado.

As fases foram escolhidas de acordo com dados da literatura, sendo consideradas as fases: austenita, ferrita (alfa e delta), líquido, MnS e (Fe,Mn)S, carbonitretos dos tipos $M(C, N)$ e $M_{2}(C, N)$, carbonetos dos tipos $M_{23} C_{6}$ e $M_{7} C_{3}$, fase Sigma e nitreto do tipo $\mathrm{Fe}_{4} \mathrm{~N}$.

\subsection{Difração de raios $X$}

A análise dos difratogramas foi realizada inicialmente com auxílio do programa Match!.Como procedimento de análise dos difratogramas, os padrões de difração (cartões ICCD da base de dados ICCD - PDF2 - 2006) foram sobrepostos aos padrões de difração experimentais. A presença ou não das fases foi avaliada através da compatibilidade dos picos de difração dos padrões ICCD com relação aos picos de difração dos padrões experimentais através de comparação. Através do programa Match!, foi utilizada a ferramenta de análise pela função de mérito ${ }^{\vee}$ (FOM) e pelo fator de escalavi para auxiliar na detecção das fases presentes.

Todas as fases possíveis foram marcadas, incluindo-se as fases que não apresentam quantidades significativas. Tais fases foram incluídas na análise, designadas "traços", visto que os principais picos de difração coincidem com os picos das fases majoritárias e estas fases (traços) poderiam estar presentes em pequenas quantidades como foi verificado pela posterior modelagem termodinâmica.

Após as análises com o programa Match!, os resultados obtidos foram validados por análise de Rietveld com o programa TOPAS Academic v.4.1. Nesta etapa as estruturas cristalográficas de todas as fases identificadas nas análises com o programa Match! foram obtidas e inseridas para serem refinadas no programa TOPAS Academic. A qualidade dos refinos foi avaliada pela comparação entre os

\footnotetext{
${ }^{\checkmark}$ A função de mérito (FOM) relaciona as intensidades e posicionamento dos picos de difração experimentais com relação ao padrão JCPDS e provê uma probabilidade (valor entre 0 e 1) do cartão JCPDS considerado estar efetivamente presente no difratograma analisado.

vi Número entre 0 e 1 que multiplica os valores das intensidades dos picos de difração dos cartões JCPDS para ajustar com os picos de difração experimentais. Este valor pode ser utilizado para uma "aproximação qualitativa" da quantidade de fases na amostra.
} 
parâmetros de rede calculados e os parâmetros de rede dos cartões ICCD; pela compatibilidade entre o difratograma calculado e o experimental; pela porcentagem (em \% em átomos) das fases calculadas (porcentagens inferiores a 1,5\% foram descartadas); e pelo erro quadrático do resíduo (rWP) calculado pelo programa TOPAS Academic.

\subsection{Tratamentos térmicos}

Os tratamentos térmicos foram realizados em um forno tubular da marca Grion (220V, 3kW). Neste forno foi acoplada uma retorta de Inconel munida de flange com duas saídas para conexão de vácuo. Na figura 4.3 apresenta-se a visão do conjunto.

A bomba de vácuo utilizada é da marca Edwards modelo E2M18 (380V, $0,75 \mathrm{~kW}$ ) que permite vazão de $5 \mathrm{~L} / \mathrm{min}$. Esta bomba quando acoplada na retorta do forno permite a obtenção de pressões da ordem de $10^{-3} \mathrm{~atm}$, o que evita a oxidação das amostras. Como meio de evitar descarbonetação e oxidação durante os tratamentos térmicos, foram também adicionados cavacos de titânio ao cadinho.

Os tratamentos térmicos seguiram o seguinte procedimento:

a) Aquecimento do forno sob atmosfera estática de argônio até cerca de $20^{\circ} \mathrm{C}$ acima da temperatura desejada para compensar a perda na abertura do forno para colocação das amostras,

b) Colocação das amostras e de cavacos de titânio no cadinho do forno com atmosfera dinâmica de argônio,

c) Ativação da bomba de vácuo e fechamento do fluxo de gás argônio, com a realização de três purgas dos gases,

d) Tratamento térmico pelo período desejado,

e) Quebra do vácuo com fluxo de argônio (5L/min),

f) Retirada das amostras e têmpera destas em água.

Neste trabalho foram realizados seis tratamentos térmicos. De modo a se reduzir a influência da recristalização na obtenção de estruturas de equilíbrio, os tratamentos térmicos foram realizados em amostras dos aços laminadas à quente, recozidas e decapadas quimicamente (BQB). A escolha das amostras decapadas foi feita de modo a possibilitar análise visual de uma possível oxidação das amostras durante os tratamentos térmicos. Todos os tratamentos térmicos realizados foram feitos por 5 h seguindo-se o procedimento descrito acima, nas temperaturas de 600, 


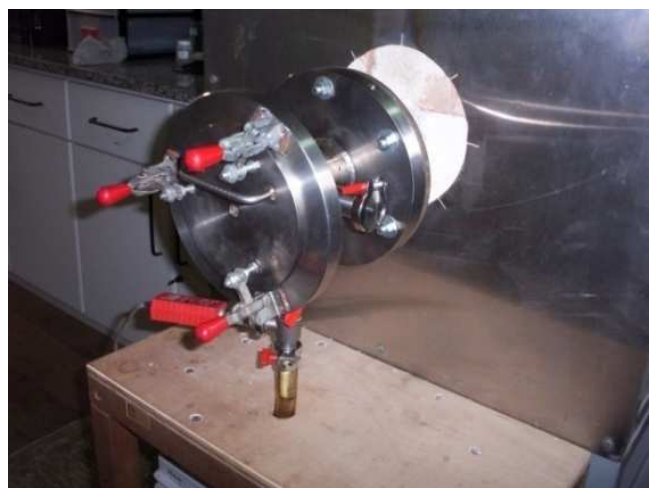

(a)

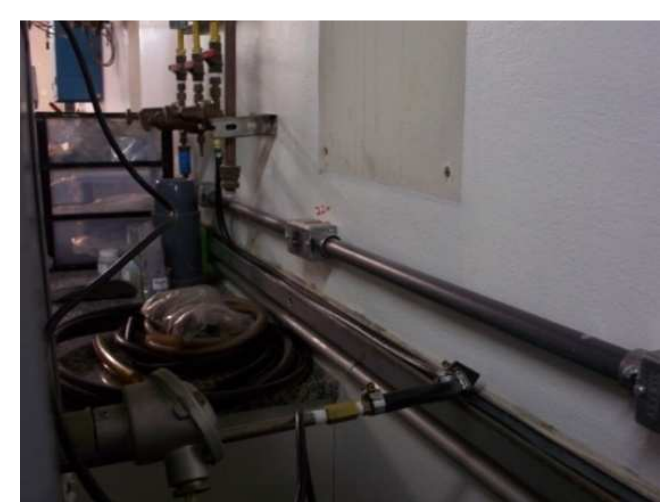

(b)

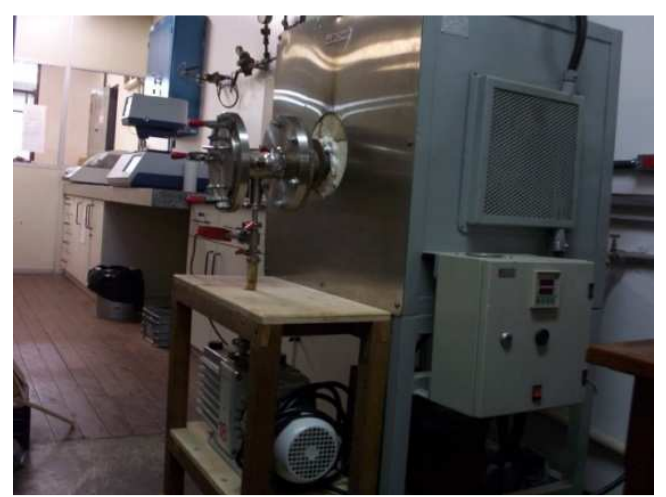

(c)

Figura 4.3: Foto do conjunto forno e retorta. (a) visa frontal, (b) vista do fundo do forno (c) vista do conjunto (bomba de vácuo + retorta + forno).

\subsection{Análise térmica diferencial (DTA)}

Os ensaios de análise térmica diferencial (DTA) foram realizados no IPT (Instituto de Pesquisas Tecnológicas do Estado de São Paulo) para a amostra do aço AISI 430 convencional na condição BQB. Os ensaios consistiram de três ciclos térmicos com taxas de resfriamento decrescentes, assim como indicado na figura 4.4 .

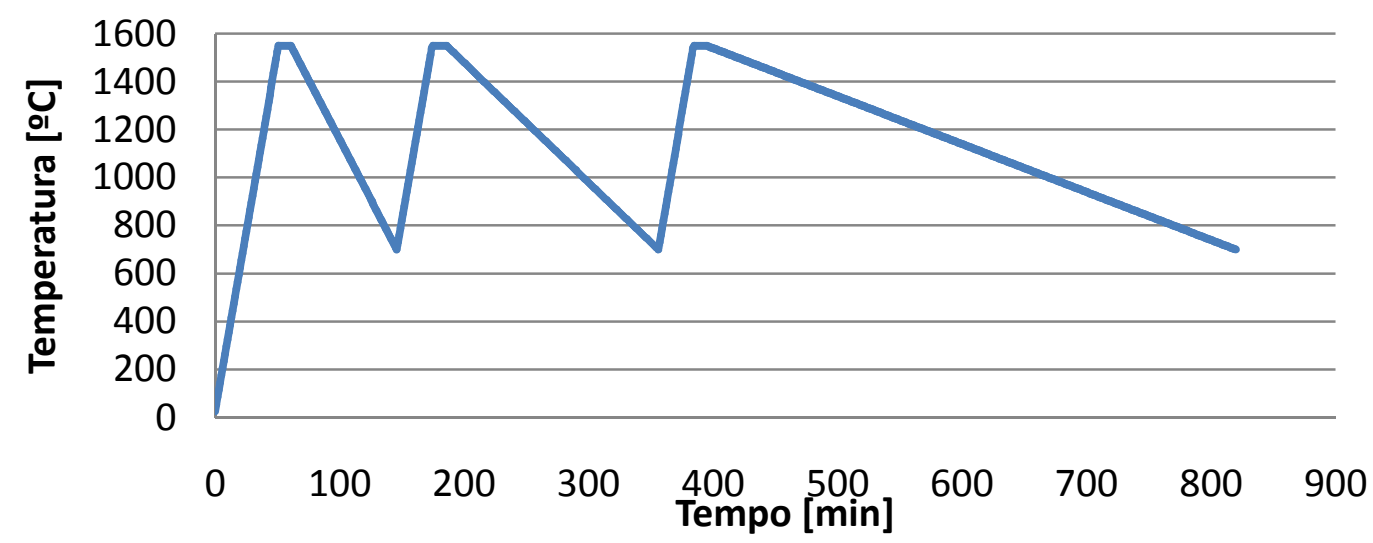

Figura 4.4: Ciclo térmico utilizado nas análises térmicas diferenciais (DTA). 
$\mathrm{O}$ primeiro ciclo térmico iniciou-se a $25^{\circ} \mathrm{C}$ com taxa de aquecimento de $30^{\circ} \mathrm{C} / \mathrm{min}$ até $1550^{\circ} \mathrm{C}$, seguido de patamar de $10 \mathrm{~min}$ a $1550^{\circ} \mathrm{C}$ e resfriamento com taxa de $10^{\circ} \mathrm{C} / \mathrm{min}$ até $700^{\circ} \mathrm{C}$.O segundo ciclo térmico teve início a $700^{\circ} \mathrm{C}$ com taxa de aquecimento de $30^{\circ} \mathrm{C} / \mathrm{min}$ até $1550^{\circ} \mathrm{C}$, seguido de patamar de $10 \mathrm{~min}$ a $1550^{\circ} \mathrm{C}$ e resfriamento com taxa de $5^{\circ} \mathrm{C} / \mathrm{min}$ até $700^{\circ} \mathrm{C}$.O terceiro ciclo térmico iniciou-se a $700^{\circ} \mathrm{C}$ com taxa de aquecimento de $30^{\circ} \mathrm{C} / \mathrm{min}$ até $1550^{\circ} \mathrm{C}$, seguido de patamar de $10 \mathrm{~min}$ a $1550^{\circ} \mathrm{C}$ e resfriamento com taxa de $2^{\circ} \mathrm{C} / \mathrm{min}$ até $700^{\circ} \mathrm{C}$.

Os resultados do DTA foram analisados através do cálculo da derivada pontual da curva do DTA com respeito a temperatura feita com o programa Oringin v.8.0, e comparação com os resultados da metalografia, difração de raios-X e modelagem termodinâmica. 


\subsection{Resultados}

Neste trabalho o aço AISI 430 foi estudado, em três condições industriais (BQB, BQP e BFB) e seis tratamentos térmicos $\left(600^{\circ} \mathrm{C} / 5 \mathrm{~h}, 700^{\circ} \mathrm{C} / 5 \mathrm{~h}, 800^{\circ} \mathrm{C} / 5 \mathrm{~h}\right.$, $90^{\circ} \mathrm{C} / 5 \mathrm{~h}, 1000^{\circ} \mathrm{C} / 5 \mathrm{~h}$ e $1100^{\circ} \mathrm{C} / 5 \mathrm{~h}$ ), através do empreg o das técnicas de difração de raios-X (DR-X) da matriz e dos precipitados extraídos, microscopia ótica (MO), microscopia eletrônica de varredura (MEV), simulações termodinâmicas e análise térmica diferencial (DTA).

De modo a simplificar as apresentação dos resultados, os resultados serão apresentados separados por técnica empregada. No item 5.1 serão apresentados os resultados da modelagem termodinâmica, no item 5.2 os resultados da DR-X, no item 5.3 os resultados da caracterização microestrutural (MO e MEV), e no item 5.4 os resultados do DTA. A reunião dos dados para a avaliação da seqüência de transformações de fases do aço AISI 430 convencional será realizada no item 6.

\subsection{Modelagem termodinâmica}

A modelagem termodinâmica do aço AISI 430 foi realizada com auxílio do programa ThermoCalc versão $\mathrm{R}$ aliado ao banco de dados TCFE2. Foi considerada na modelagem a composição química apresentada na tabela 4.1. Dos elementos químicos apresentados na tabela 4.1, somente o estanho e o chumbo não foram considerados nos cálculos devido à inexistência da descrição destes elementos no banco de dados termodinâmicos TCFE2.

$\mathrm{Na}$ figura 5.1 apresentam-se os diagramas de equilíbrio de fases do aço AISI 430 com a composição apresentada na tabela 4.1 obtidos com o programa ThermoCalc ${ }^{\circledR}$ aliado ao banco de dados TCFE2.

Com base nos diagramas da figura 5.1 foi determinada a seqüência de solidificação em equilíbrio apresentada na tabela 5.1. As fases marcadas na cor vermelha indicam as fases que estão sendo precipitadas ou dissolvidas durante a solidificação em equilíbrio. 


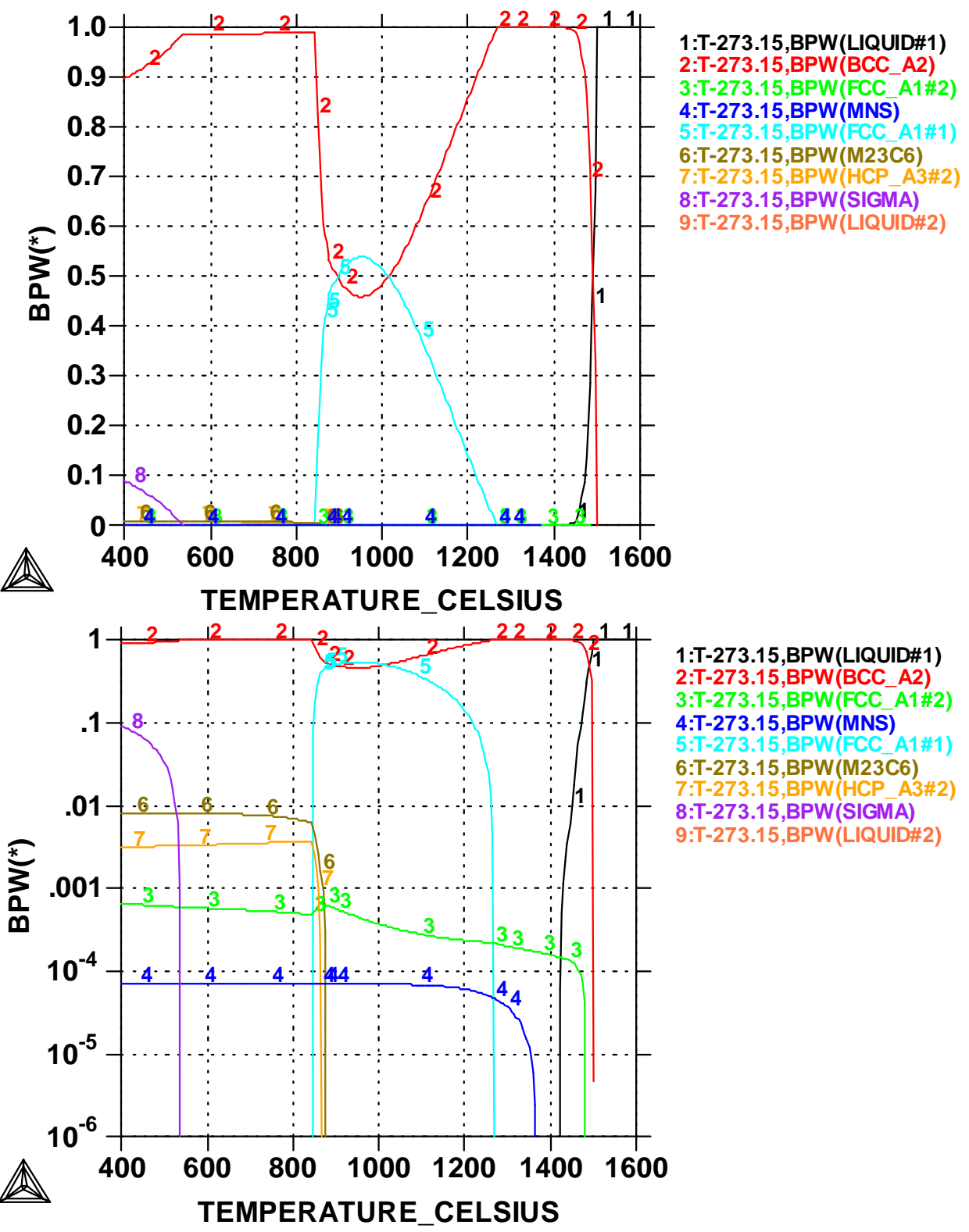

(a)

(b)

Figura 5.1: Diagramas de equilíbrio de fases do aço AISI 430 calculados com o programa ThermoCalc ${ }^{\circledR}$ aliado ao banco de dados TCFE2. (BPW é a fração mássica das fases em equilíbrio) (a) Eixo das ordenas em escala linear e (b) Eixo das ordenas em escala logarítmica.

Tabela 5.1: Seqüência de solidificação em equilíbrio do aço AISI 430.

\begin{tabular}{|l|c|}
\hline \multicolumn{1}{|c|}{ Transformações de Fases } & T[C] \\
\hline$L \rightarrow L^{\prime}+\delta$ & 1499 \\
\hline$L^{\prime}+\delta \rightarrow L^{\prime}+\delta+M(C, N)$ & 1484 \\
\hline$L^{\prime \prime}+\delta+M(C, N) \rightarrow \delta+M(C, N)$ & 1419 \\
\hline$\delta+M(C, N) \rightarrow \delta+M(C, N)+M n S$ & 1368 \\
\hline$\delta+M(C, N)+M n S \rightarrow \delta+M(C, N)+M n S+\gamma$ & 1267 \\
\hline$\delta+M(C, N)+M n S+\gamma \rightarrow \delta+M(C, N)+M n S+\gamma+M_{23} C_{6}$ & 877 \\
\hline$\delta+M(C, N)+M n S+\gamma+M_{23} C_{6} \rightarrow \delta+M(C, N)+M n S+\gamma+M_{23} C_{6}+M_{2}(C, N)$ & 866 \\
\hline$\delta+M(C, N)+M n S+\gamma+M_{23} C_{6}+M_{2}(C, N) \rightarrow \alpha+M(C, N)+M n S+M_{23} C_{6}+M_{2}(C, N)$ & 840 \\
\hline$\alpha+M(C, N)+M n S+M_{23} C_{6}+M_{2}(C, N) \rightarrow \alpha+M(C, N)+M n S+M_{23} C_{6}+M_{2}(C, N)+\sigma$ & 535 \\
\hline
\end{tabular}

Aliando-se os diagramas da figura 5.1 aos dados da tabela 5.1, observa-se que, em equilíbrio, a solidificação do aço AISI 430 procede da seguinte maneira: 
i) O aço AISI 430 é um aço hipoperitético, apresentando a ferrita $\delta$ como fase primária,

ii) No campo líquido através de uma reação eutética ocorre a precipitação de células de $(M(C, N)+\delta)$, em torno de $1484^{\circ} \mathrm{C}$, sendo o carbonitreto majorit ariamente constituído pelo nitreto $(\mathrm{Nb}, \mathrm{Ti}) \mathrm{N}$,

iii) Observa-se que o aço AISI 430 apresenta um domínio de equilíbrio bifásico $(\alpha+\gamma)$ entre as temperaturas de $840^{\circ} \mathrm{C}$ e $1267{ }^{\circ} \mathrm{C}$,

iv) A precipitação do carboneto do tipo $\mathrm{M}_{23} \mathrm{C}_{6}$, majoritariamente constituído por $(\mathrm{Cr}, \mathrm{Fe})_{23} \mathrm{C}_{6}$, ocorre antes da precipitação do carbonitreto do tipo $\mathrm{M}_{2}(\mathrm{C}, \mathrm{N})$, a $877^{\circ} \mathrm{C}$, iniciando-se no domínio bifásico $(\alpha / \gamma)$,

v) A precipitação do carbonitreto do tipo $\mathrm{M}_{2}(\mathrm{C}, \mathrm{N})$, majoritariamente constituído pelo nitreto $(\mathrm{Cr}, \mathrm{V}, \mathrm{Nb})_{2} \mathrm{~N}$ ocorre a $8^{\circ 66} \mathrm{C}$, iniciando-se no final do domínio bifásico $(\alpha / \gamma)$, vi) A precipitação da fase sigma ocorre apenas em temperaturas inferiores a $535^{\circ} \mathrm{C}$.

Segundo a modelagem termodinâmica, este aço apresenta teores de ( $\mathrm{Nb}, \mathrm{Ti}) \mathrm{N}$ que precipitam-se ainda no estado líquido. A previsão da presença deste nitreto neste aço refere-se ao estado de equilíbrio termodinâmico global. Farina ${ }^{(43)}$, Farina et al. ${ }^{(59)}$. e Chéhab et al. ${ }^{(60)}$, verificaram em um aço inoxidável do tipo AISI410 $(11 \% \mathrm{Cr})$ com baixo teor de intersticiais, que embora a modelagem termodinâmica preveja a formação deste nitreto, mesmo com uma extensa varredura da microestrutura por Microscopia Eletrônica de Transmissão, não foi verificada a presença desta fase. Assim concluiu-se que a cinética de formação foi lenta, ou que não houve potencial para nucleação desta fase.

\subsection{Difração de raios-X}

Foram realizados ensaios de difração de raios- $X$ das 3 amostras na condição industrial e das 6 amostras tratadas termicamente. Os difratogramas foram analisados inicialmente com o programa Match! aliado a base de dados ICCD-PDF2 (2006) para indexação dos picos de difração. Todos os picos de difração foram considerados nesta análise preliminar, incluindo-se os picos presentes na radiação de fundo. Após a identificação dos picos de difração, os difratogramas foram analisados com o programa TOPAS Academic de análise de Rietveld para verificação dos picos indexados e quantificação das fases presentes.

No item 5.2.1 serão apresentados os resultados de difração de raios-X das 
amostras sólidas $^{\text {vii }}$ (matriz) e no item 5.2.2 os resultados da difração de raios-X dos precipitados extraídos. No anexo 1 são apresentados todos os cartões de estruturas cristalinas utilizados para a indexação de cada uma das fases.

\subsubsection{Difração da matriz}

Dos difratogramas da matriz, verificou-se somente a presença da fase ferrita. As amostras BFB e as amostras tratadas termicamente a $6000^{\circ} \mathrm{C}, 7000^{\circ} \mathrm{C}$ e $800^{\circ} \mathrm{C}$ apresentaram somente um tipo de ferrita, assim como previsto pelos cálculos termodinâmicos. As demais amostras (BQP, BQB, tratadas a $900^{\circ} \mathrm{C}, 1^{\circ}{ }^{\circ} \mathrm{C}$ $1100^{\circ} \mathrm{C}$ ) apresentaram duas fases ferrita, sendo compatíveis com uma microestrutura dúplex (ferrita + martensita). Nas figuras 5.2 e 5.3 são apresentados padrões de difração de raios-X típicos para amostras com apenas uma fase ferrita (condição BQB e tratada a $600{ }^{\circ} \mathrm{C} / 5 \mathrm{~h}$ ) e com duas fase s ferrita (condição BQB e tratado a $11000^{\circ} / 5 \mathrm{~h}$ ) respectivamente ${ }^{\text {viii }}$. Na tabela 5.2 apresentam-se os resultados da análise de Rietveld para os difratogramas da matriz.

Tabela 5.2: Resultados da análise de Rietveld para os difratogramas da matriz.

\begin{tabular}{|c|c|c|c|c|c|c|c|}
\hline Parâmetro & \multicolumn{2}{|c|}{$\begin{array}{c}\text { Quantificação } \\
\text { (\% at. fases) } \\
\text { Erro: } \pm 20 \%\end{array}$} & \multicolumn{2}{|c|}{$\begin{array}{c}\text { Parâmetro de rede }(\AA) \\
\text { Erro: } \pm 0.001(\AA)\end{array}$} & \multicolumn{2}{c|}{$\begin{array}{c}\text { Parâmetro "r" } \\
\text { do modelo de March } \\
\text { (Orientação Preferencial) }\end{array}$} & $\begin{array}{c}\text { Resíduo } \\
\text { quadrático } \\
\text { Erro: } \pm 0.1\end{array}$ \\
\hline Amostra & $\begin{array}{c}\text { Ferrita } \\
\text { baixo } \\
\text { cromo }\end{array}$ & $\begin{array}{c}\text { Ferrita } \\
\text { de alto } \\
\text { cromo }\end{array}$ & $\begin{array}{c}\text { Ferrita } \\
\text { baixo } \\
\text { cromo }\end{array}$ & $\begin{array}{c}\text { Ferrita } \\
\text { alto } \\
\text { cromo }\end{array}$ & $\begin{array}{c}\text { Ferrita baixo } \\
\text { cromo }\end{array}$ & $\begin{array}{c}\text { Ferrita alto } \\
\text { cromo }\end{array}$ & $r_{\text {WP }}$ \\
\hline BQP & 27.6 & 73.4 & 2.872 & 2.875 & 0.307 & 0.494 & 15.3 \\
\hline BQB & 34.1 & 65.9 & 2.871 & 2.874 & 0.423 & 0.634 & 16.6 \\
\hline BFB & 100.0 & - & 2.872 & - & não utilizado & - & 14.9 \\
\hline $600^{\circ} \mathrm{C} / 5 \mathrm{~h}$ & 100.0 & - & 2.873 & - & 0.524 & - & 18.2 \\
\hline $700^{\circ} \mathrm{C} / 5 \mathrm{~h}$ & 100.0 & - & 2.873 & - & 0.566 & - & 17.9 \\
\hline $800^{\circ} \mathrm{C} / 5 \mathrm{~h}$ & 100.0 & - & 2.873 & - & 0.562 & - & 17.7 \\
\hline $9^{\circ} \mathrm{C} / 5 \mathrm{~h}$ & 66.0 & 34.0 & 2.873 & 2.884 & 0.515 & 0.679 & 16.9 \\
\hline $1000^{\circ} \mathrm{C} / 5 \mathrm{~h}$ & 66.3 & 33.6 & 2.873 & 2.883 & 0.526 & 0.690 & 16.2 \\
\hline $1100^{\circ} \mathrm{C} / 5 \mathrm{~h}$ & 67.8 & 32.2 & 2.873 & 2.884 & 0.530 & 0.782 & 15.6 \\
\hline
\end{tabular}

Dos cartões ICCD para as fases ferrita (Fe- $\alpha$ - cl2 - PDF: 006-0696 $\mathrm{a}=2.8664 \AA \hat{)})$ e $(\mathrm{Fe}-11.7 \% \mathrm{Cr}$ - cl2 - PDF: 034-0396 - a=2.876 ̊́) foi observado que o parâmetro de rede da ferrita aumenta com o aumento do teor de cromo dissolvido. Com base neste fato os parâmetros de rede das duas fases ferrita foram separados

\footnotetext{
vii A partir deste ponto por questão de simplificação da linguagem, a difração de raios- $X$ realizada na superfície polida das amostras metálicas será chamada de "difração da matriz".

viii Em todos os difratogramas, a curva em vermelho representa o difratograma calculado, a curva azul de fundo o difratograma experimental e as demais curvas os difratogramas para cada uma das fases presentes.
} 
em ferrita de alto cromo e ferrita de baixo cromo. Entretanto, esta classificação é meramente comparativa visto que como será apresentado no item 5.3.2.6, a diferença entre os teores de $\mathrm{Cr}$ é da ordem de $1 \%$ em peso. No entanto como o aço AISI 430 apresenta baixo teor de elementos de liga (1,12\% em peso total) com exceção do $\operatorname{Cr}$ (16,00\% em peso), esta classificação para a fase ferrita pode ser empregada sem prejuízos à informação.

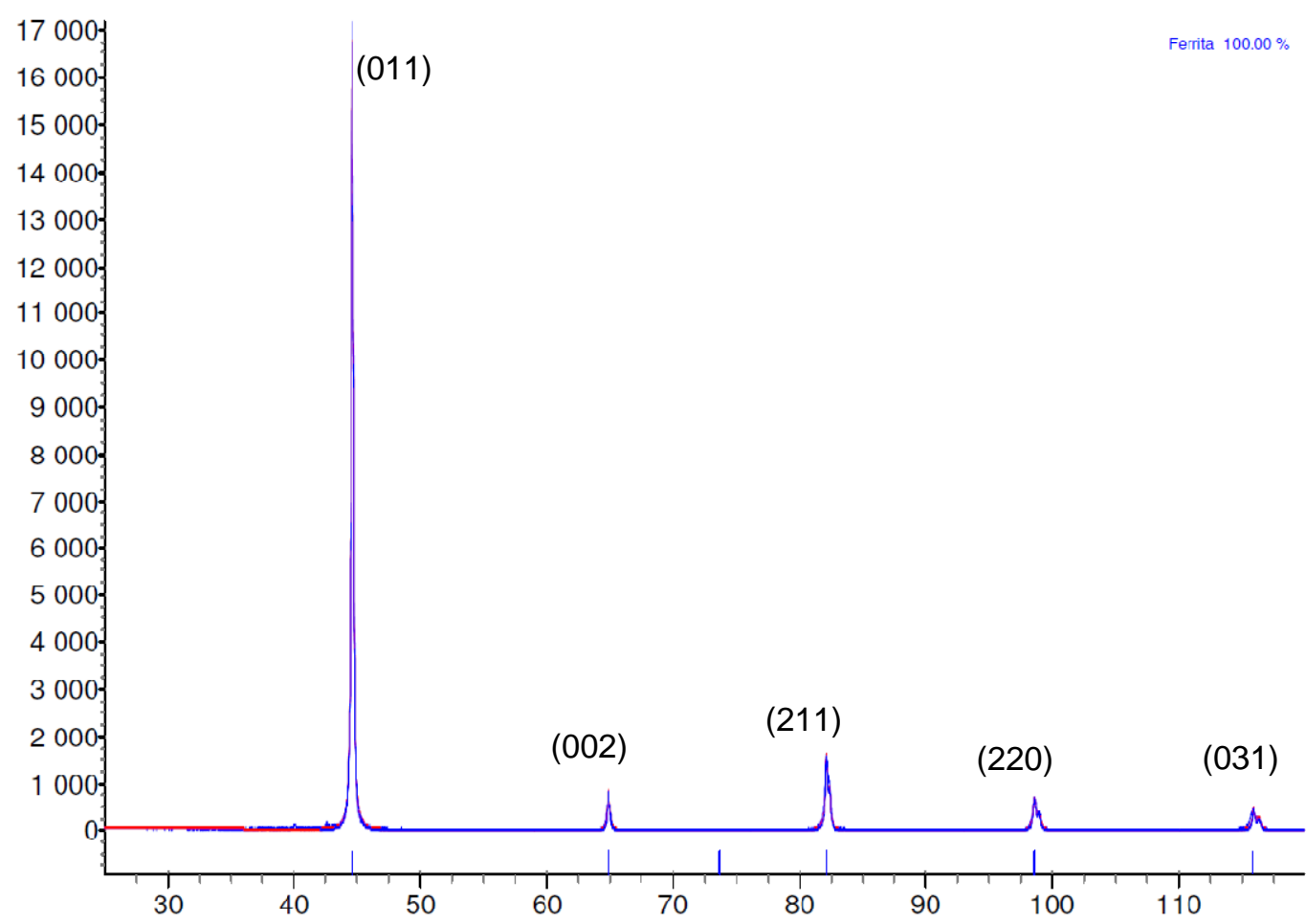

(a)

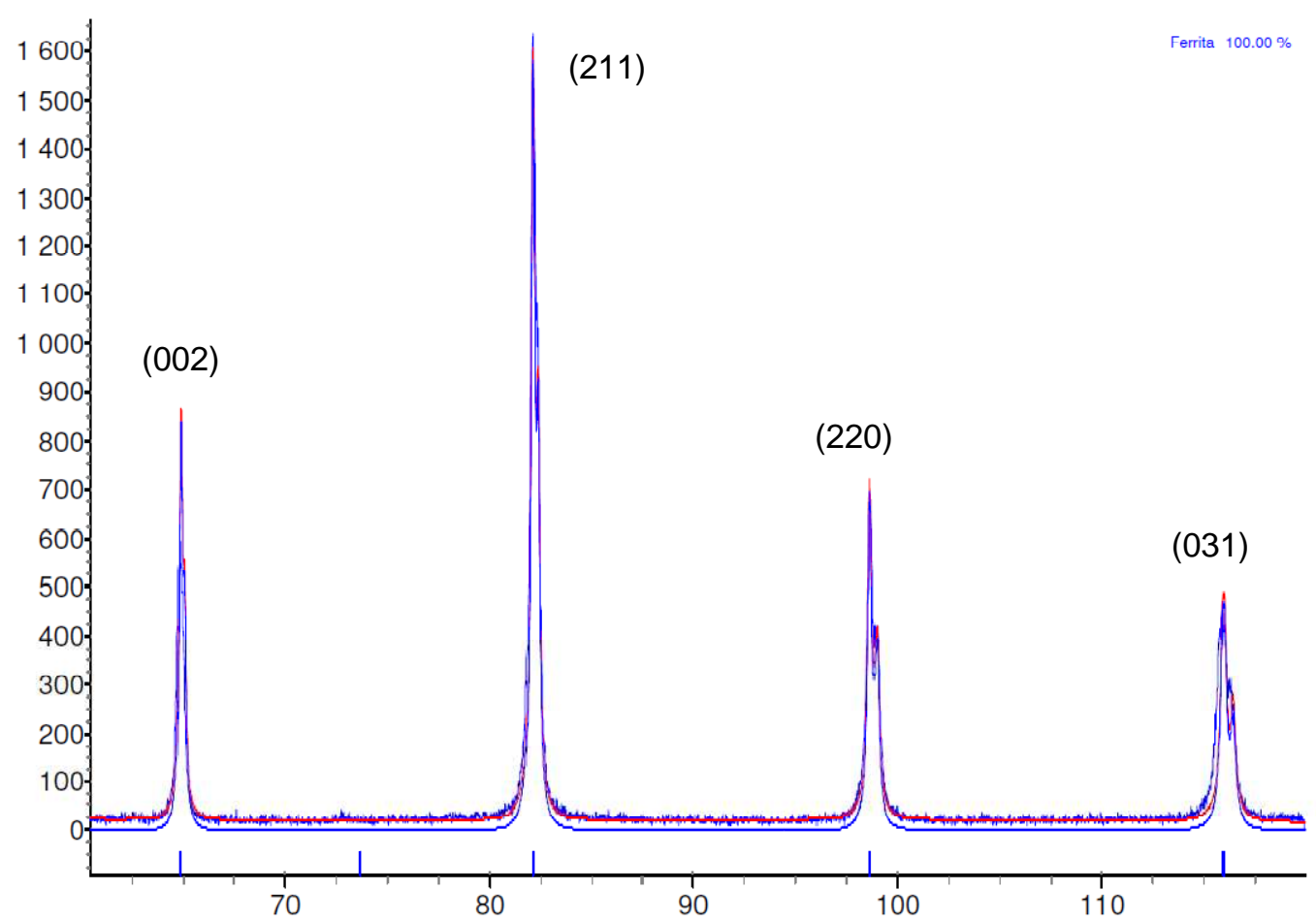

(b)

Figura 5.2: Difratograma da matriz do aço AISI 430 na condição BQB e tratado a $600{ }^{\circ} \mathrm{C} / 5 \mathrm{~h}$. Difratograma obtido com radiação CuK $\alpha$. (a) Difratograma completo. (b) Ampliação da região entre $60^{\circ}$ e $120^{\circ}$. 


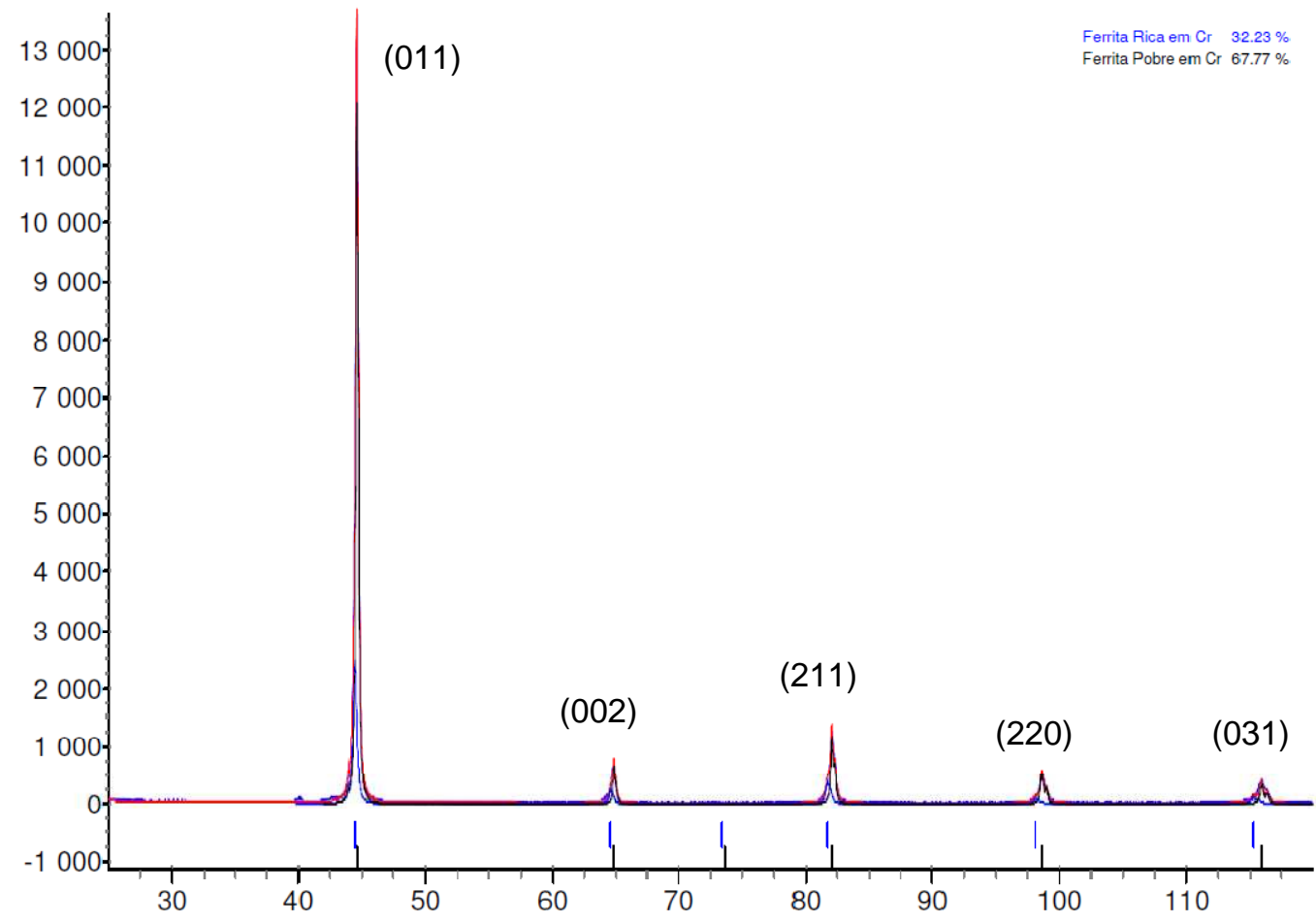

(a)

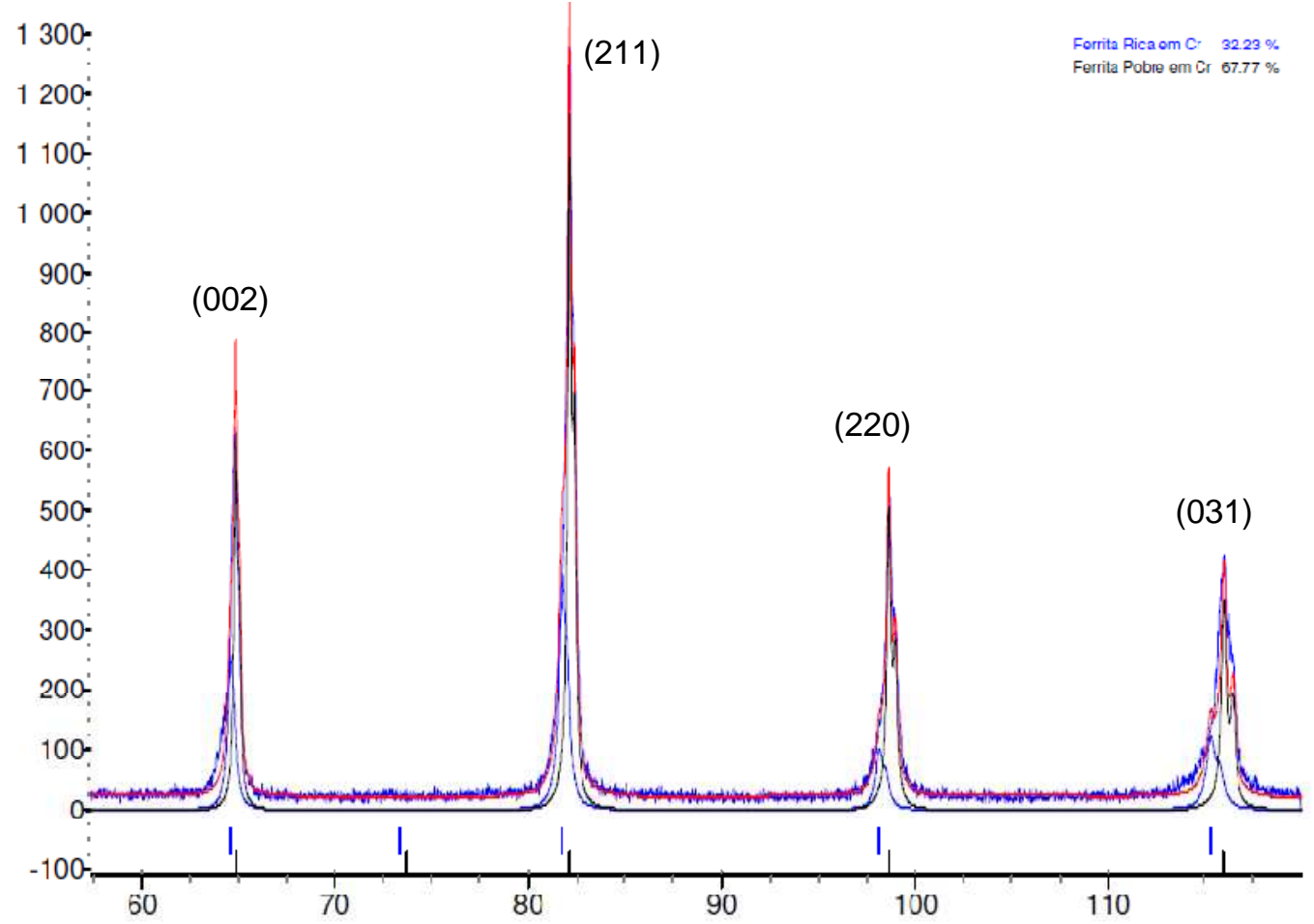

(b)

Figura 5.3: Difratograma da matriz do aço AISI 430 na condição $B Q B$ e tratado a $1100{ }^{\circ} / 5 \mathrm{~h}$. Difratograma obtido com radiação CuK $\alpha$. (a) Difratograma completo. (b) Ampliação da região entre $60^{\circ}$ e $120^{\circ}$.

Observa-se que o erro na quantificação dos teores de fase ferrita é de cerca de $20 \%$. Este erro apresenta tal valor devido ao emprego do modelo de March para a o ajuste da orientação preferencial dos planos (011). Ao se aplicar este modelo, o programa produz alterações significativas no cálculo do fator de Lorentz (largura do pico de difração) e na intensidade dos picos difratados. O ajuste dos parâmetros de 
rede é feito de modo que a convolução das intensidades do picos de difração calculados, para ambos os tipos de ferrita, atinja a menor diferença numérica em relação às intensidades do difratograma experimental. Ao se fazer esta aproximação da orientação preferencial, o refino pelo método de Rietveld automaticamente perde a possibilidade de uma quantificação precisa $( \pm 1 \%)$, podendo ser utilizado em casos especiais, como o deste trabalho, apenas para uma avaliação qualitativa da quantidade de fases, ou simplesmente indicar que existem duas fases diferentes e que estas apresentam-se em quantidades diferentes. No entanto, com o uso do modelo de March para orientação preferencial, a determinação do parâmetro de rede se torna um pouco mais precisa, visto que o difratograma calculado e 0 experimental passam a ser mais coerentes entre si.

Nas amostras que apresentaram somente a fase ferrita de "baixo cromo" este erro pode ser desconsiderado, visto que é a única fase presente no difratograma.

\subsubsection{Difração dos precipitados extraídos}

Os difratogramas dos precipitados extraídos revelaram a presença do carboneto do tipo $(\mathrm{Cr}, \mathrm{Fe})_{23} \mathrm{C}_{6}$ e do nitreto do tipo $(\mathrm{Cr}, \mathrm{Fe})_{2} \mathrm{~N}$, além de diversos produtos de extração. $\mathrm{Na}$ tabela 5.3 são apresentados os resultados obtidos para a difração de raios- $X$ dos precipitados extraídos. 
Tabela 5.3:Resultados da análise de Rietveld para os difratogramas dos precipitados extraídos. (a, b e c são os parâmetros de rede, sempre em $\AA$ ). As respectivas estruturas cristalinas e parâmetros de rede da literatura são apresentadas no Anexo 1.

\begin{tabular}{|c|c|c|c|c|c|c|c|c|c|}
\hline \multirow{2}{*}{ Amostra } & \multicolumn{3}{|c|}{$\mathrm{Cr}_{2} \mathrm{~N}$} & \multicolumn{2}{|c|}{$\mathrm{M}_{23} \mathrm{C}_{6}$} & \multicolumn{4}{|c|}{$\mathrm{CrO}_{3}$} \\
\hline & $\%$ at. & $a[\AA]$ & $c[\AA ̊]$ & $\%$ at. & $\mathrm{a}[\AA]$ & $\%$ at. & $\mathrm{a}[\AA]$ & $\mathrm{b}[\AA]$ & $c[\AA]$ \\
\hline BQP & 12.0 & 4.851 & 4.167 & - & - & - & - & - & - \\
\hline BQB & 38.8 & 4.810 & 4.458 & 47.6 & 10.606 & 13.6 & 5.083 & 9.042 & 5.270 \\
\hline $\mathrm{BFB}$ & 66.6 & 4.821 & 4.452 & 29.2 & 10.589 & 5.3 & 4.873 & 8.362 & 5.663 \\
\hline $600^{\circ} \mathrm{C} / 5 \mathrm{~h}$ & 41.0 & 4.797 & 4.457 & 24.8 & 10.587 & - & - & - & - \\
\hline $700^{\circ} \mathrm{C} / 5 \mathrm{~h}$ & 8.2 & 4.790 & 4.497 & 3.4 & 10.595 & - & - & - & - \\
\hline $800^{\circ} \mathrm{C} / 5 \mathrm{~h}$ & 36.2 & 4.827 & 4.461 & 7.2 & 10.605 & - & - & - & - \\
\hline $900^{\circ} \mathrm{C} / 5 \mathrm{~h}$ & 10.3 & 5.105 & 4.572 & 2.9 & 10.618 & - & - & - & - \\
\hline $1000^{\circ} \mathrm{C} / 5 \mathrm{~h}$ & - & - & - & 1.3 & 10.692 & - & - & - & - \\
\hline $1100^{\circ} \mathrm{C} / 5 \mathrm{~h}$ & - & - & - & - & - & - & - & - & - \\
\hline \multirow{2}{*}{ Amostra } & \multicolumn{2}{|c|}{$\mathrm{KCl}$} & \multicolumn{3}{|c|}{$\mathrm{Cr}_{2} \mathrm{O}_{3}$} & \multicolumn{4}{|c|}{$\mathrm{Cu}_{2} \mathrm{Cl}(\mathrm{OH})_{3}-$ Botallackita } \\
\hline & $\%$ at. & $\mathrm{a}[\AA]$ & $\%$ at. & $a[\AA]$ & $c[\AA]$ & $\%$ at. & $\mathrm{a}[\AA]$ & $\mathrm{b}[\AA]$ & $c[\AA]$ \\
\hline $\mathrm{BQP}$ & - & - & 25.56 & 5.031 & 13.606 & - & - & - & - \\
\hline$B Q B$ & - & - & - & - & - & - & - & - & - \\
\hline BFB & - & - & - & - & - & - & - & - & - \\
\hline $600^{\circ} \mathrm{C} / 5 \mathrm{~h}$ & 28.5 & 6.275 & 3.0 & 4.812 & 14.104 & - & - & - & - \\
\hline $700^{\circ} \mathrm{C} / 5 \mathrm{~h}$ & - & - & - & - & - & - & - & - & - \\
\hline $800^{\circ} \mathrm{C} / 5 \mathrm{~h}$ & - & - & 16.31 & 4.985 & 13.554 & - & - & - & - \\
\hline $900^{\circ} \mathrm{C} / 5 \mathrm{~h}$ & 20.1 & 6.312 & 21.6 & 4.979 & 13.512 & - & - & - & - \\
\hline $1000^{\circ} \mathrm{C} / 5 \mathrm{~h}$ & - & - & 14.2 & 4.999 & 13.605 & 39.0 & 5.716 & 6.122 & 5.625 \\
\hline $1100^{\circ} \mathrm{C} / 5 \mathrm{~h}$ & - & - & - & - & - & - & - & - & - \\
\hline \multirow{2}{*}{ Amostra } & \multicolumn{2}{|c|}{$\mathrm{FeO} \cdot \mathrm{Cr}_{2} \mathrm{O}_{3}$} & \multicolumn{3}{|c|}{$\mathrm{Cu}_{2} \mathrm{Cl}(\mathrm{OH})_{3}$-Paratacamita } & \multicolumn{2}{|c|}{$\mathrm{Cu}$} & \multirow{2}{*}{\multicolumn{2}{|c|}{$r_{W P}$}} \\
\hline & $\%$ at. & $\mathrm{a}[\AA]$ & $\%$ at. & $\mathrm{a}[\AA]$ & $c[\AA]$ & $\%$ at. & $\mathrm{a}[\AA]$ & & \\
\hline BQP & 58.4 & 8.367 & - & - & - & - & - & \multicolumn{2}{|c|}{12.7} \\
\hline$B Q B$ & - & - & - & - & - & - & - & \multicolumn{2}{|c|}{28.2} \\
\hline BFB & - & - & - & - & - & - & - & \multicolumn{2}{|c|}{31.0} \\
\hline $600^{\circ} \mathrm{C} / 5 \mathrm{~h}$ & 2.6 & 7.964 & - & - & - & - & - & \multicolumn{2}{|c|}{25.6} \\
\hline $700^{\circ} \mathrm{C} / 5 \mathrm{~h}$ & - & - & 88.4 & 6.826 & 14.047 & - & - & \multicolumn{2}{|c|}{22.1} \\
\hline $800^{\circ} \mathrm{C} / 5 \mathrm{~h}$ & - & - & 10.2 & 6.825 & 14.063 & 30.1 & 3.610 & \multicolumn{2}{|c|}{20.0} \\
\hline $900^{\circ} \mathrm{C} / 5 \mathrm{~h}$ & - & - & 45.2 & 6.913 & 14.078 & - & - & \multicolumn{2}{|c|}{15.5} \\
\hline $1000^{\circ} \mathrm{C} / 5 \mathrm{~h}$ & - & - & - & - & - & 45.5 & 3.613 & \multicolumn{2}{|c|}{21.2} \\
\hline $1100^{\circ} \mathrm{C} / 5 \mathrm{~h}$ & 3.9 & 8.404 & 96.0 & 6.833 & 14.093 & - & - & \multicolumn{2}{|c|}{32.3} \\
\hline \multicolumn{10}{|c|}{ Erros: } \\
\hline Quantifica & o: Err & $\pm 1 \%$ & Parân & tros de & ede: Erro & \pm 0.00 & & wp: Errc & \pm 0.1 \\
\hline
\end{tabular}

Nas figuras 5.4 e 5.5 são apresentados exemplos dos difratogramas obtidos para os precipitados extraídos. 


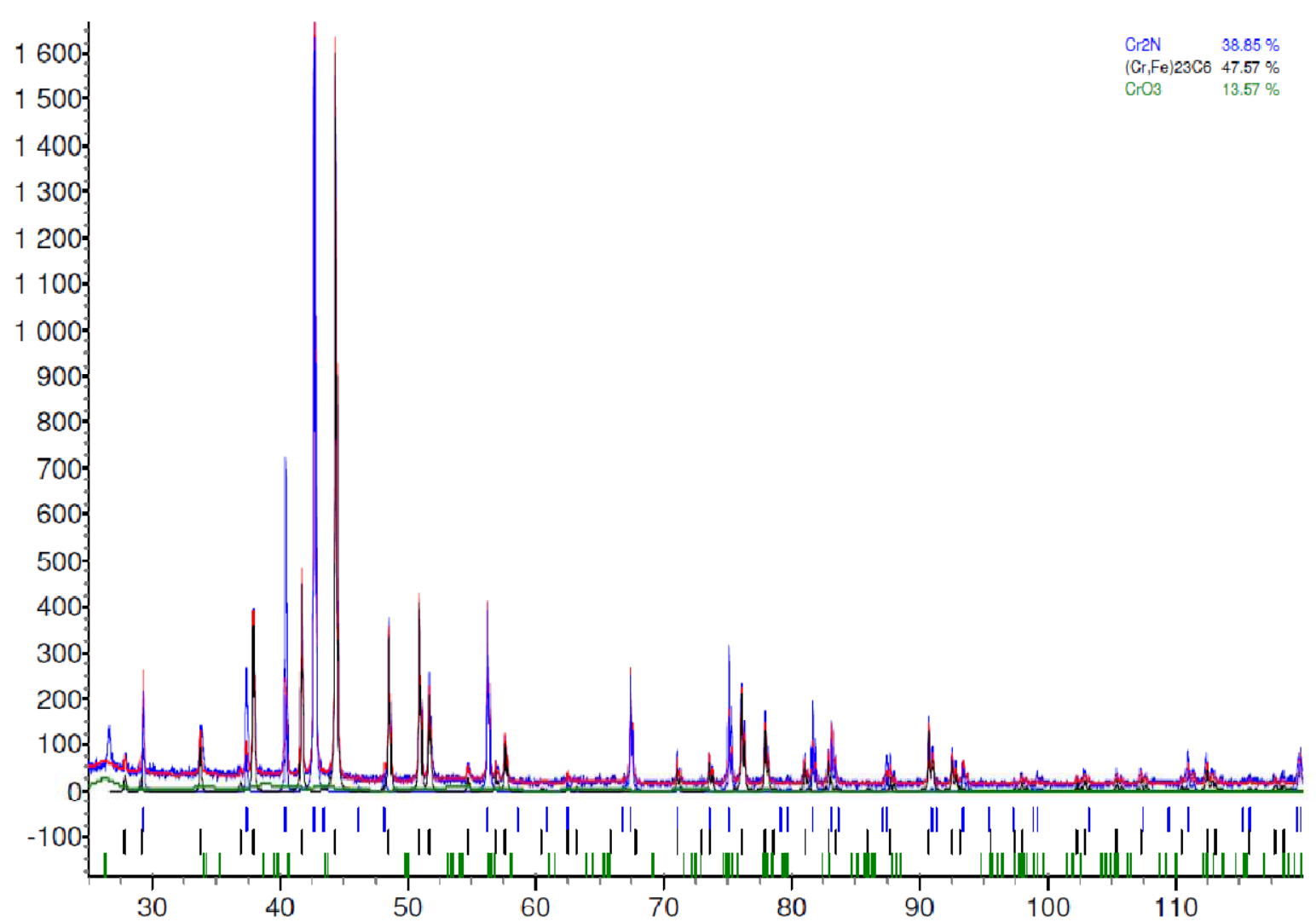

Figura 5.4: Difratograma dos precipitados extraídos do aço AISI 430 na condição BQB. Difratograma obtido com radiação CuKa.

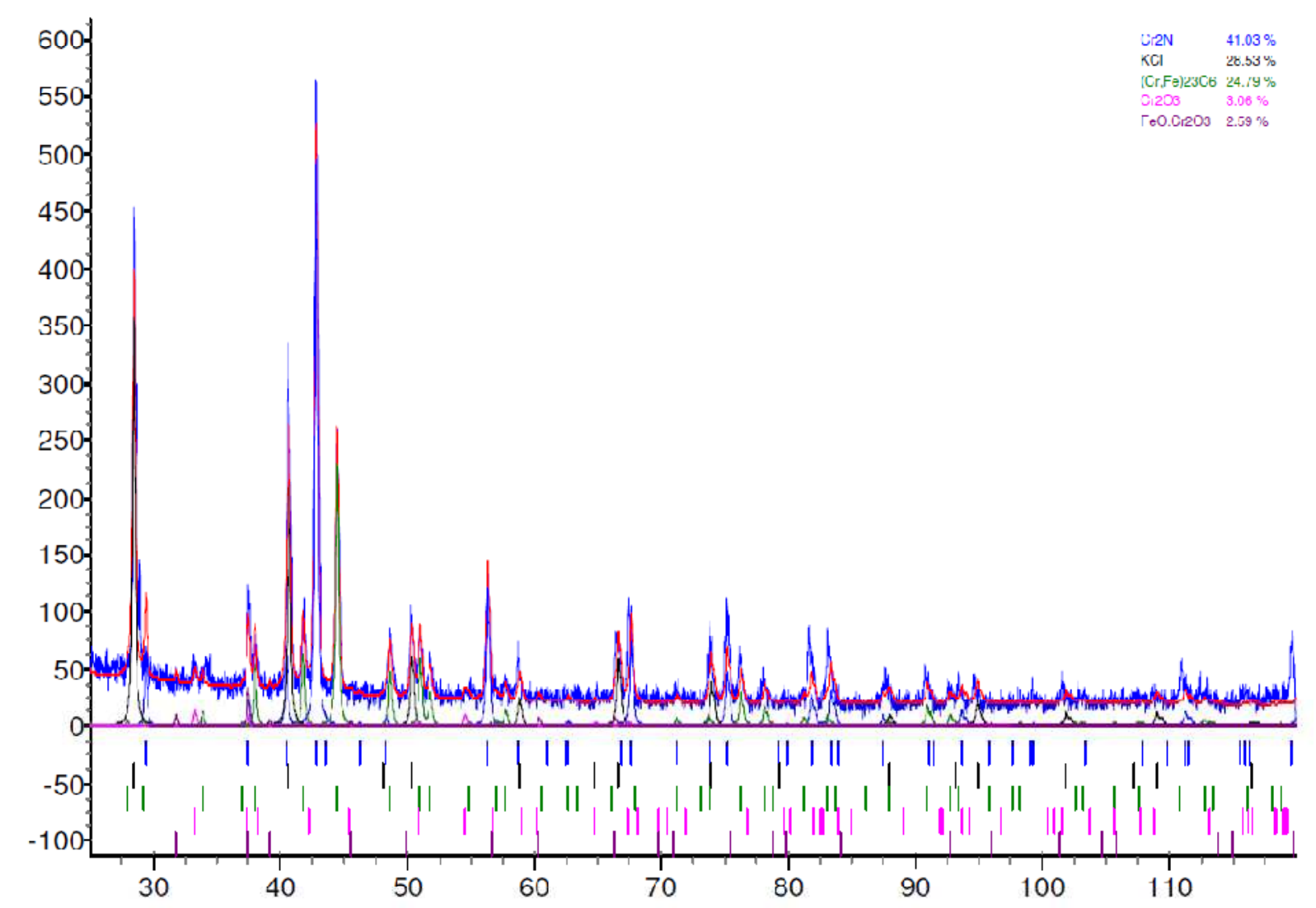

Figura 5.5: Difratograma dos precipitados extraídos do aço AISI 430 na condição BQB e tratado a $900^{\circ} \mathrm{C} / 5 \mathrm{~h}$. Difratograma obtido com radiação CuK $\alpha$. 


\subsection{Caracterização microestrutural}

De modo a simplificar a apresentação, serão apresentadas separadamente as amostras das condições industriais das amostras tratadas termicamente. No item 5.3.1 serão apresentadas as amostras na condição industrial e no item 5.3.2 serão apresentadas as amostras tratadas termicamente.

\subsubsection{Condições industriais}

\subsubsection{Condição BQP}

Na figura 5.6 apresentam-se micrografias do aço AISI 430 na condição BQP obtidas em MO com ataque por reagente de Kalling's 1 e com reagente Villela. $O$ reagente de Kalling's 1 colore a ferrita em cinza (preto no campo escuro). A martensita é colorida na cor preta (cinza no campo escuro) e carbonetos e partículas de segunda fase não são atacados. Nas micrografias da figura 5.6 (a) e (c) se observa que a matriz do aço AISI 430 na condição BQP é dúplex apresentando ferrita e martensita, dispostas com estrutura quase lamelar. Foi verificado por MO com aumento de $1000 x$ a presença de pequenos precipitados pretos na microestrutura (figura 5.6(d)).

$\mathrm{Na}$ figura 5.7 se apresentam micrografias em MEV sem ataque do aço AISI 430 na condição BQP, onde verifica-se que este aço apresenta efetivamente uma microestrutura dúplex com duas fases de composições levemente diferentes em função dos dois tons de cinza presentes nas micrografias obtidas por elétrons retroespalhados. A análise química via EDS das duas fases é apresentada na tabela 5.4.

Tabela 5.4: Análise química via EDS (\% em peso) do aço AISI 430 na condição BQP, referente à micrografia da figura 5.7(d).

\begin{tabular}{|c|c|c|c|c|c|c|}
\hline Ponto & Fase & Si & $\mathbf{C r}$ & $\mathbf{M n}$ & $\mathbf{F e}$ & $\mathbf{N i}$ \\
\hline $\mathbf{1}$ & Matriz Escura & 0,3 & 17,1 & 0,5 & 82,0 & --- \\
\hline $\mathbf{2}$ & Matriz Clara & 0,2 & 16,3 & 0,5 & 82,4 & 0,6 \\
\hline
\end{tabular}

Da tabela 5.10 em conjunto com a micrografia da figura 5.7(b), observa-se que a fase clara apresenta menor teor de cromo e apresenta níquel em pequena quantidade, já a fase escura apresenta maior teor de cromo e não apresenta níquel. A diferença de composição é claramente identificada nas micrografias óticas obtidas com ataque por reagente Villela onde se observa ataque preferencial de uma fase 
da matriz, indicando o menor teor de cromo. A diferença de composição sugere que a fase cinza escura (região 1) é a ferrita e a fase cinza clara (região 2) é a martensita identificada nas micrografias da figura 5.6 pelo reagente de Kalling's 1. A presença de martensita é justificada em função do aço AISI 430 na condição BQP ter sido laminado a quente, com a última cadeira na temperatura de $970{ }^{\circ} \mathrm{C}$, seguido de resfriamento rápido até $600{ }^{\circ} \mathrm{C}$ para bobinamento e po sterior resfriamento ao ar até a temperatura ambiente. Como foi apresentado no item 5.1 o aço AISI 430 apresenta microestrutura dúplex (austenita/ferrita) nesta temperatura.

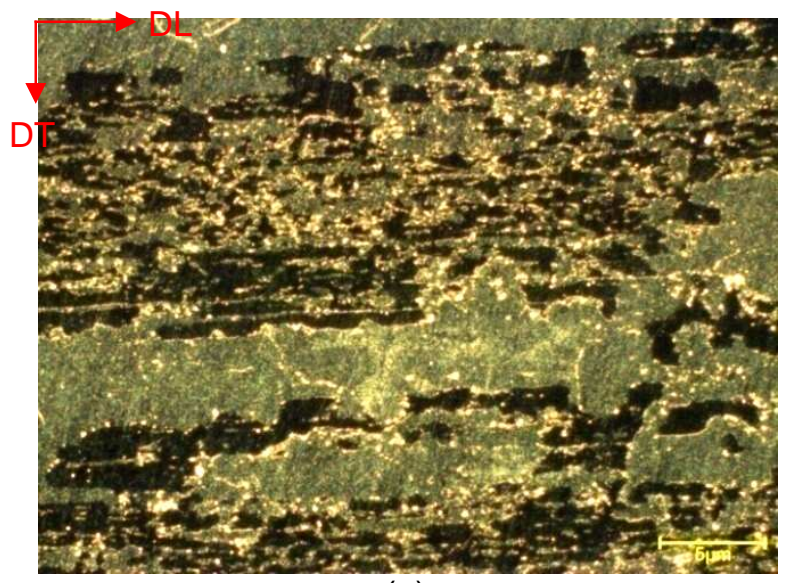

(a)

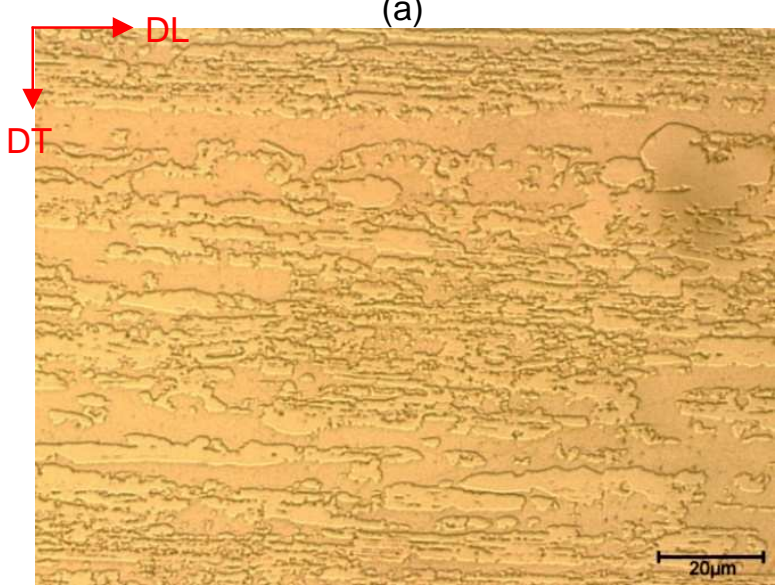

(c)

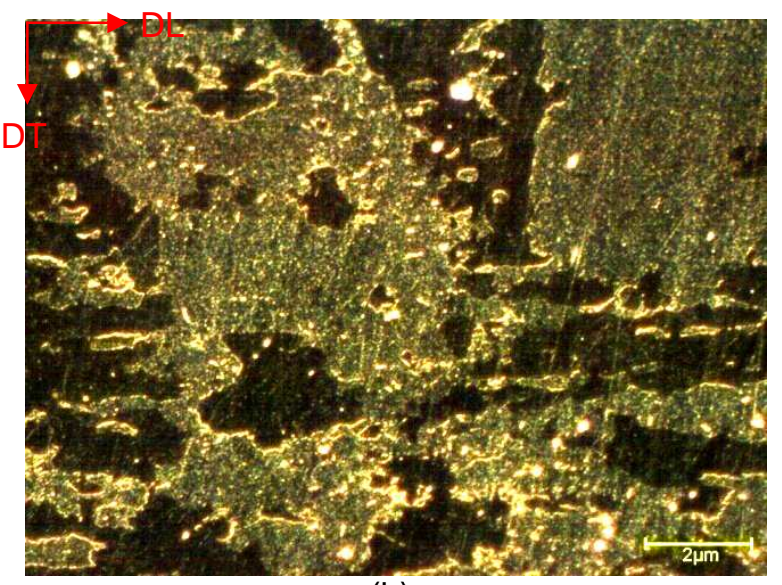

(b)

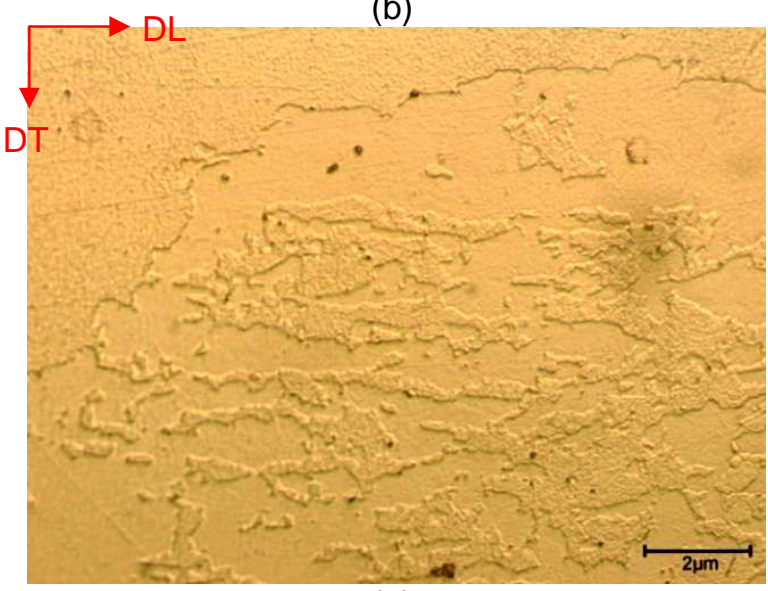

(d)

Figura 5.6: Aço AISI 430 na condição BQP. Micrografias em MO. Micrografias (a) e (b) ataque por reagente Kalling's 1, campo escuro. Micrografias (c) e (d) ataque por reagente Villela.

Assim, o aço AISI 430 na condição BQP apresenta matriz dúplex composta por ferrita de alto teor de cromo e martensita com presença de nitretos do tipo $(\mathrm{Cr}, \mathrm{Fe})_{2} \mathrm{~N}$ ricos em $\mathrm{Cr}_{2} \mathrm{~N}$. 


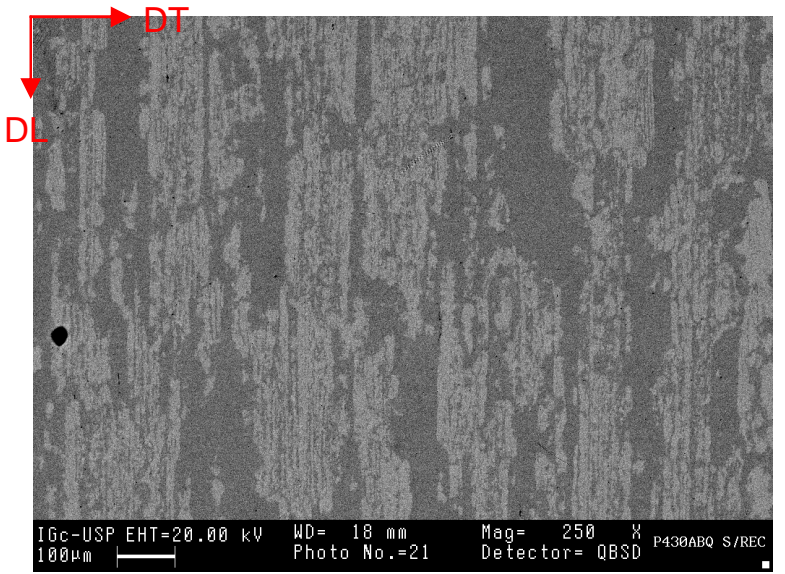

(a)

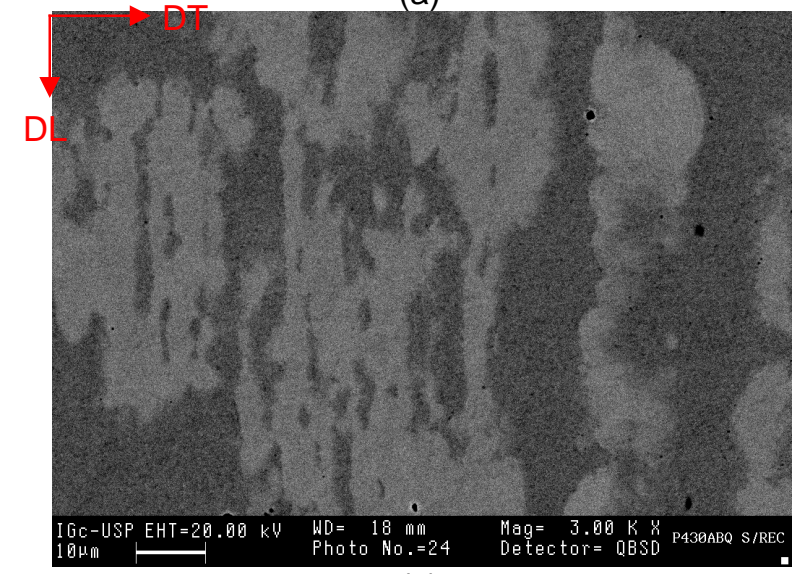

(c)

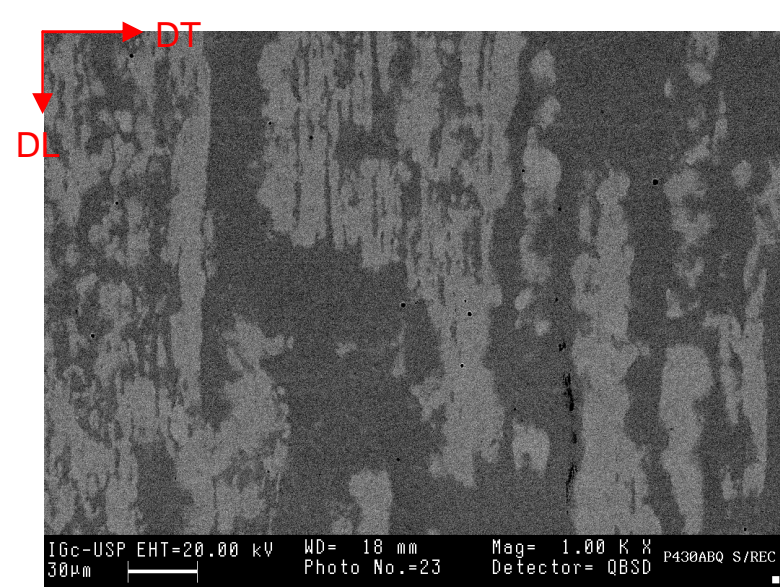

(b)

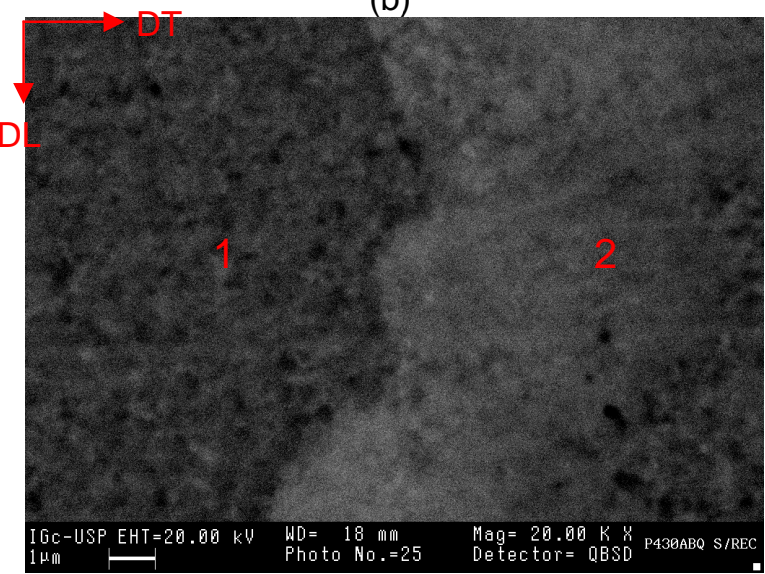

(d)

Figura 5.7: Aço AISI 430 na condição BQP. Micrografias em MEV, elétrons retroespalhados, sem ataque.

\subsubsection{Condição BQB}

Na figura 5.8 apresentam-se micrografias do aço AISI 430 na condição BQB obtidas em MO com ataque por reagente de Kalling's 1 e Villela.Nestas micrografias observa-se que a matriz do aço AISI 430 na condição BQB é constituída por uma matriz ferrítica apresentando precipitados nos contornos de grão e de alguns precipitados intragranulares. Os carbonetos observados nos contornos de grão são do tipo $(\mathrm{Cr}, \mathrm{Fe})_{23} \mathrm{C}_{6}$, assim como observado na difração de raios- $\mathrm{X}$ dos precipitados extraídos. Observa-se que há regiões recristalizadas e regiões não recristalizadas, indicando uma possível diferença de textura entre estas regiões em acordo com o trabalho de Sinclair et al. ${ }^{(19)}$.

$\mathrm{Na}$ figura 5.9 apresentam-se micrografias em MEV sem ataque do aço AISI 430 na condição $B Q B$ onde se observa que o aço AISI 430 na condição BQB apresenta presença de carbonetos e nitretos preferencialmente nos contornos de grão. Na tabela 5.5 apresentam-se as composições químicas obtidas por EDS dos pontos (1), (2) e (3) marcados na micrografia da figura 5.9(d). 


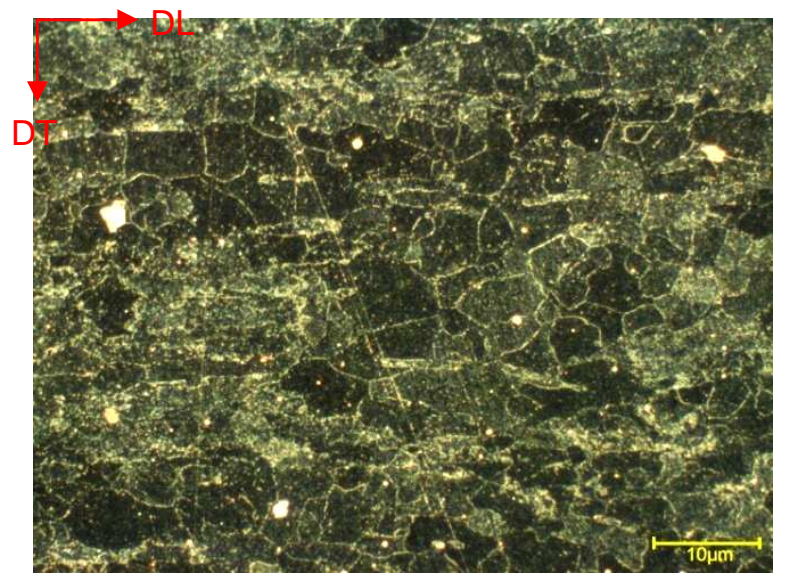

(a)

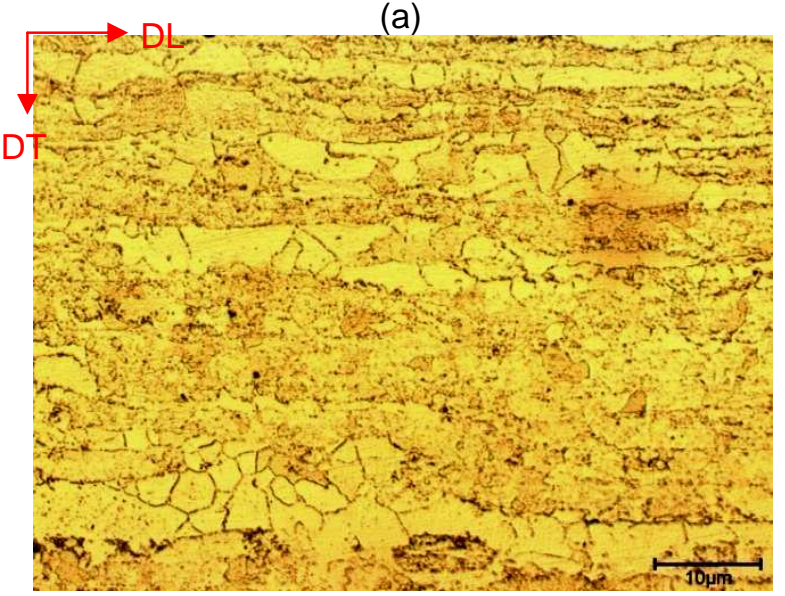

(c)

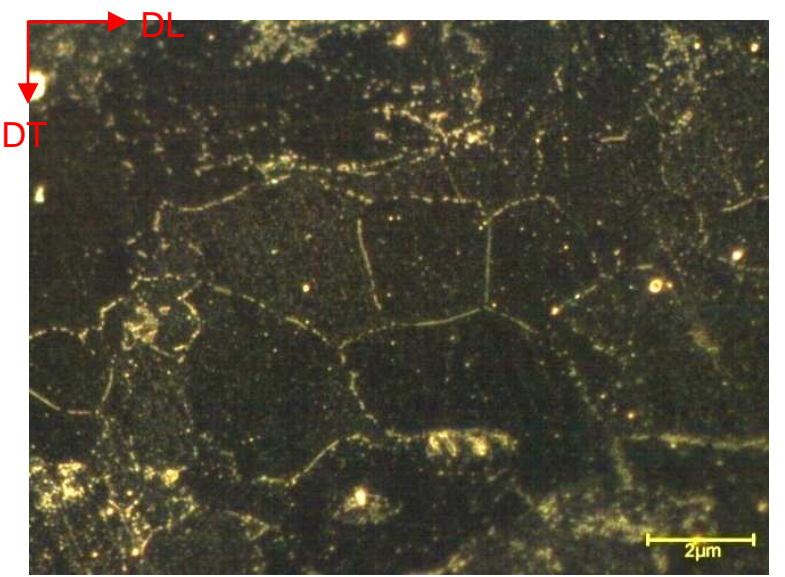

(b)

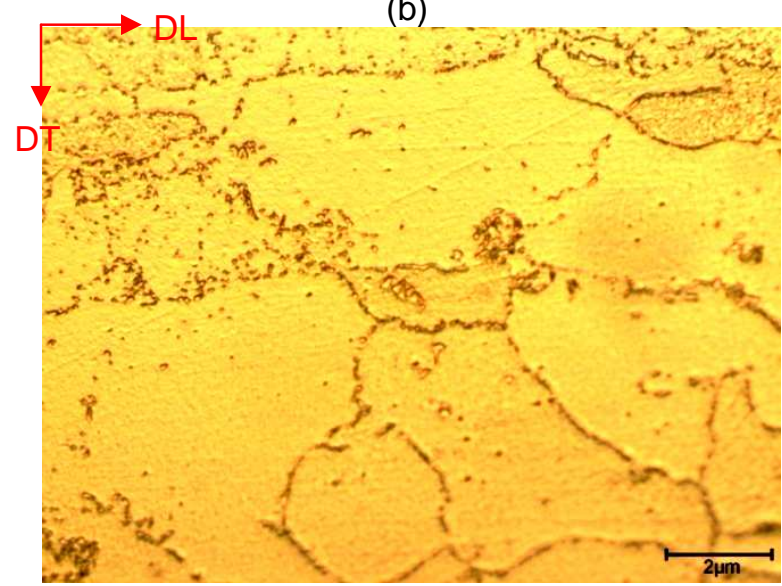

(d)

Figura 5.8: Aço AISI 430 na condição BQB. Micrografias em MO. Micrografias (a) e (b) ataque por reagente Kalling's 1. Micrografias (c) e (d) ataque por reagente Villela. Na micrografia (c) observase a presença de duas regiões, uma recristalizada e outra não. Observa-se a presença de carbonetos do tipo $\mathrm{M}_{23} \mathrm{C}_{6}$ nos contornos de grão.

Tabela 5.5: Análise química via EDS (\% em peso) do aço AISI 430 na condição $B Q B$, referente à micrografia da figura $5.9(\mathrm{~d})$.

\begin{tabular}{|c|c|c|c|c|c|c|c|c|}
\hline Ponto & Fase & $\mathbf{C r}$ & $\mathbf{F e}$ & $\mathbf{M n}$ & $\mathbf{S i}$ & $\mathbf{N}$ & $\mathbf{V}$ & $\mathbf{C}$ \\
\hline $\mathbf{1}$ & Matriz & 16,2 & 82,9 & 0,5 & 0,3 & --- & --- & --- \\
\hline $\mathbf{2}$ & Precipitado & 34,6 & 63,9 & 0,5 & 0,1 & Identificado & 0,9 & --- \\
\hline $\mathbf{3}$ & Precipitado & 31,9 & 66,6 & 0,5 & 0,2 & Identificado & 0,7 & Identificado \\
\hline
\end{tabular}

Da tabela 5.5 observa-se que os precipitados identificados são provavelmente nitretos do tipo $(\mathrm{Cr}, \mathrm{Fe}, \mathrm{V})_{2} \mathrm{~N}$ (ponto 2) e carboneto do tipo $(\mathrm{Cr}, \mathrm{Fe})_{23} \mathrm{C}_{6}$ (ponto 3), ao se comparar estes resultados com os resultados da difração de raios- $X$ dos precipitados extraídos. A análise química via EDS destes precipitados não é confiável visto que os precipitados apresentam tamanho da ordem de $0,5 \mu \mathrm{m}$ e a região de análise pelo feixe de elétrons é da ordem de $1 \mu \mathrm{m}$ de diâmetro, sugerindo que a análise química via EDS considerou também a composição da matriz do aço. 


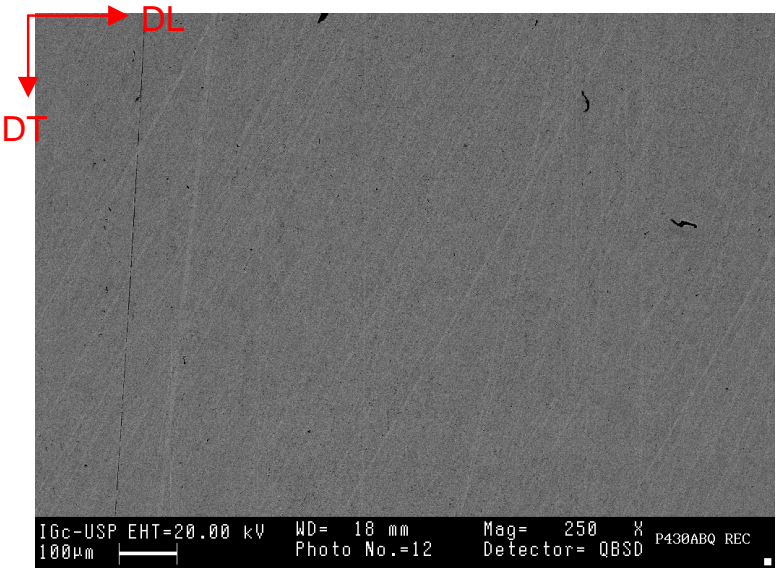

(a)

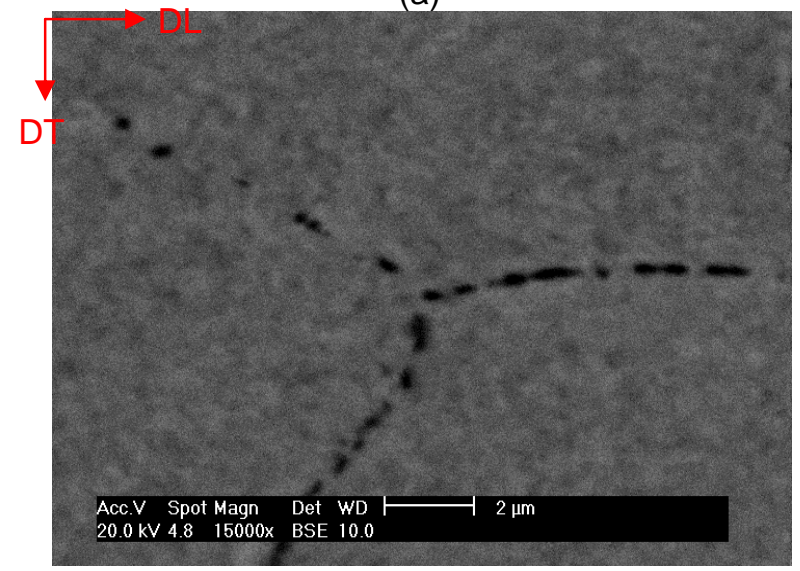

(c)

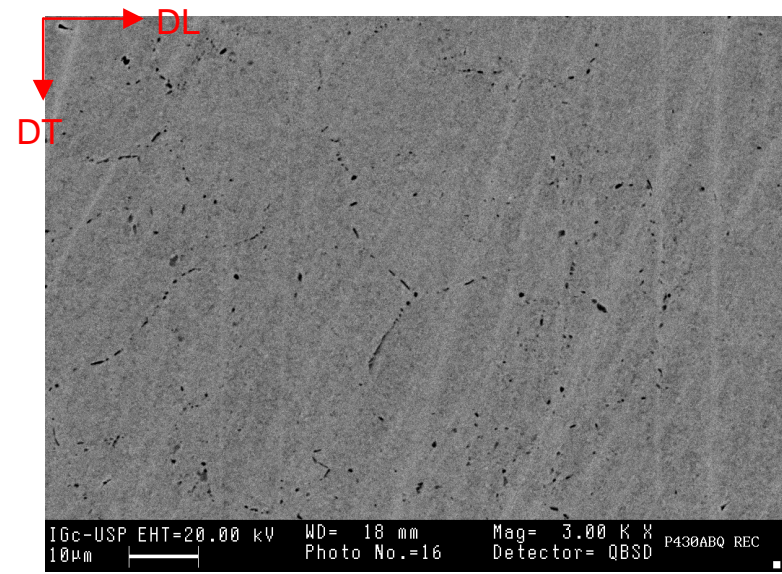

(b)

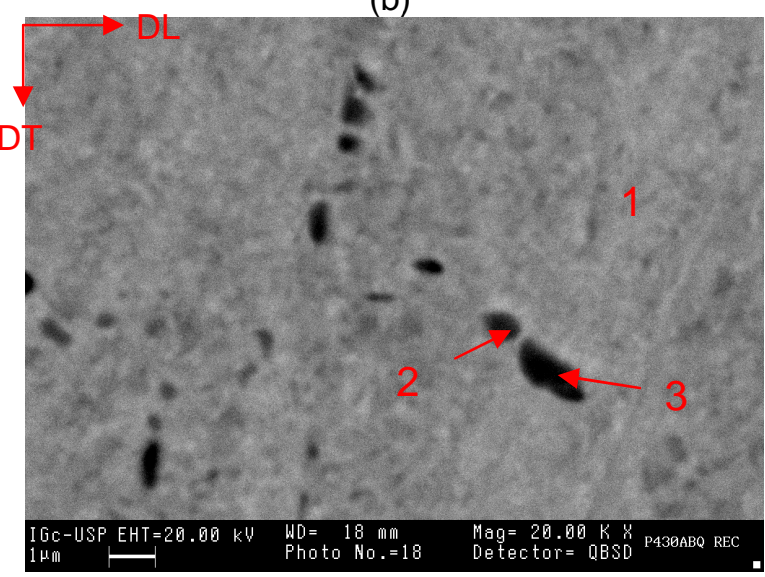

(d)

Figura 5.9: Aço AISI 430 na condição BQB. Micrografias em MEV, elétrons retroespalhados, sem ataque.

Com base nos resultados obtidos para o aço AISI 430 na condição BQB, verifica-se que este aço apresenta matriz ferrítica com alto teor de cromo e presença de nitretos do tipo $(\mathrm{Cr}, \mathrm{Fe})_{2} \mathrm{~N}$ ricos em $\mathrm{Cr}_{2} \mathrm{~N}$ e carbonetos do tipo $(\mathrm{Cr}, \mathrm{Fe})_{23} \mathrm{C}_{6}$ preferencialmente nos contornos de grão.

\subsubsection{Condição BFB}

$\mathrm{Na}$ figura 5.10 apresentam-se micrografias do aço AISI 430 na condição BF recozido obtidas em MO com ataque com os reagentes Kalling's 2 e Villela. As micrografias obtidas com ataque pelo reagente de Kalling's 2 revelam que este aço apresenta locais de ataque preferencial (pontos pretos) que são possivelmente carbonetos do tipo $(\mathrm{Cr}, \mathrm{Fe}){ }_{23} \mathrm{C}_{6}$. $\mathrm{O}$ ataque com reagente de Kalling's 2 não foi eficaz para identificar os contornos de grão. As micrografias com ataque pelo reagente Villela confirmam a presença de carbonetos e revelam os contornos de grão do aço indicando que após a laminação a frio e recozimento o aço apresenta grãos maiores e alongados em relação à condição BQB. 


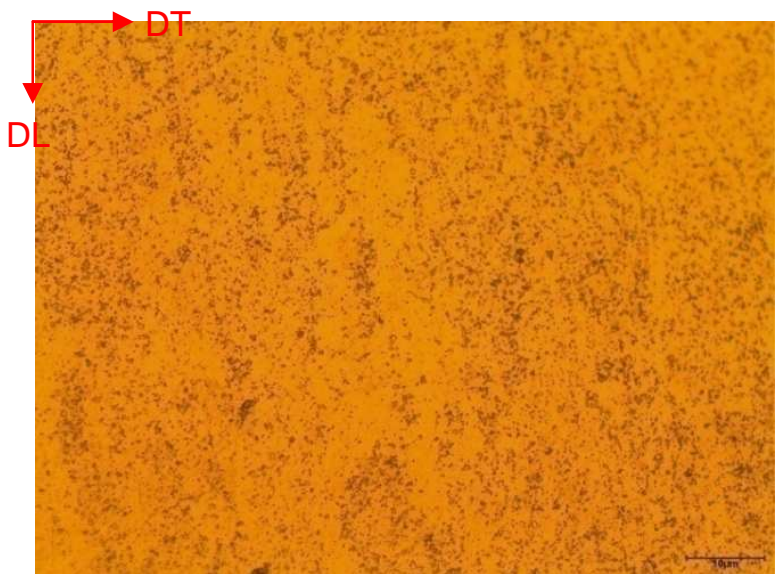

(a)

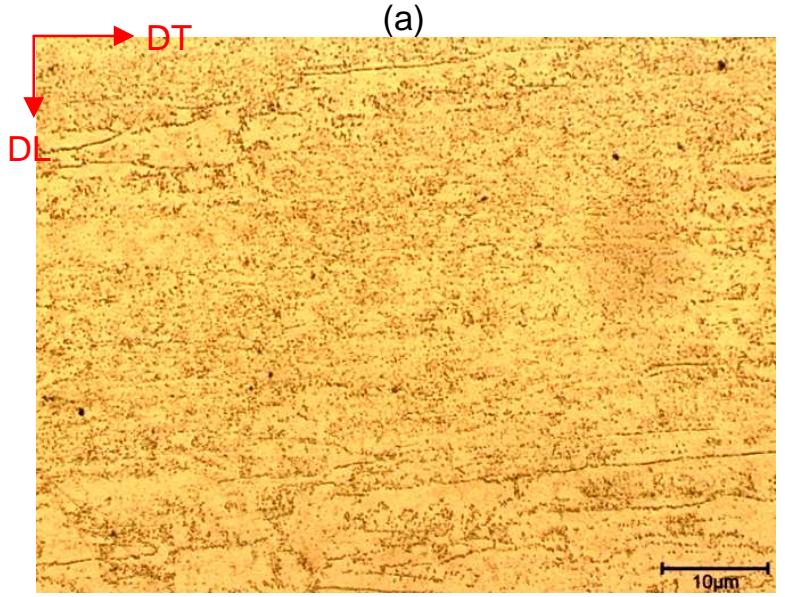

(c)

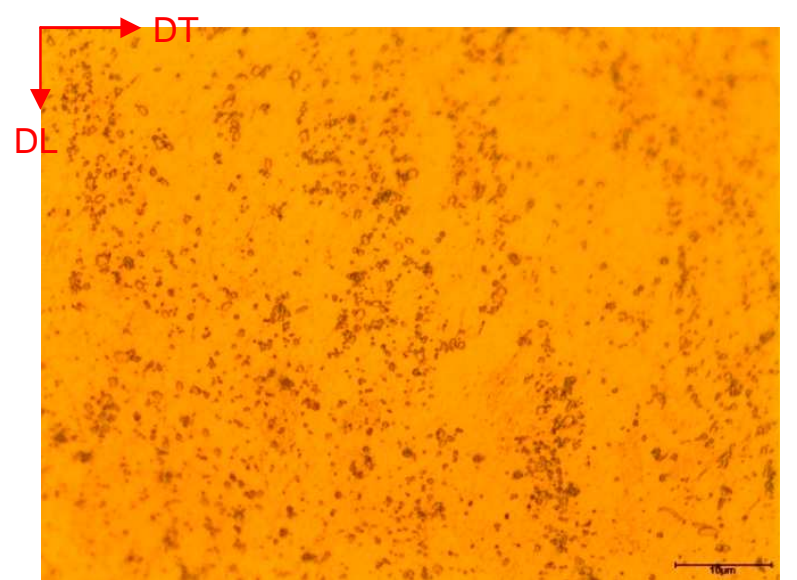

(b)

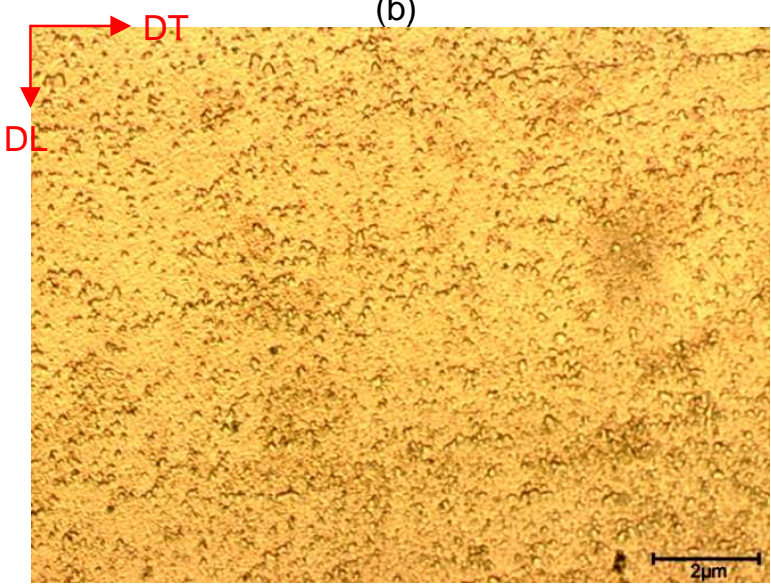

(d)

Figura 5.10: Aço AISI 430 na condição BFB. Micrografias em MO. Micrografias (a) e (b) ataque por reagente Kalling's 2. Micrografias (c) e (d) ataque por reagente Villela. Carbonetos esferoidizados do tipo $\mathrm{M}_{23} \mathrm{C}_{6}$ dispersos em uma matriz ferrítica. Embora detectado pela DR-X não são observados nitretos do tipo $(\mathrm{Cr}, \mathrm{Fe})_{2} \mathrm{~N}$ por $\mathrm{MO}$.

$\mathrm{Na}$ figura 5.11 são apresentadas micrografias em MEV para o aço AISI 430 na condição BFB com ataque por reagente Villela. Na micrografia da figura 5.11(d) observa-se que este aço apresenta grande dispersão de precipitados finos e de dois tipos (pretos e brancos). Na tabela 5.6 apresenta-se a composição química destes precipitados e da matriz obtidos com EDS.

Tabela 5.6: Análise química via EDS (\% em peso) do aço AISI 430 na condição BQB, referente à micrografia da figura 5.11 (d).

\begin{tabular}{|c|c|c|c|c|c|c|c|c|}
\hline Ponto & Fase & $\mathbf{C}$ & $\mathbf{N}$ & $\mathbf{S i}$ & $\mathbf{C r}$ & $\mathbf{M n}$ & $\mathbf{F e}$ & $\mathbf{V}$ \\
\hline $\mathbf{1}$ & Matriz & --- & --- & 0,3 & 16,2 & 0,5 & 82,9 & --- \\
\hline $\mathbf{2}$ & Precipitado escuro & --- & Ident. & 0,1 & 34,1 & 0,5 & 63,1 & 0,9 \\
\hline $\mathbf{3}$ & Matriz com precipitados claros & Ident. & Ident. & 0,2 & 30,2 & 0,5 & 63,0 & 0,7 \\
\hline
\end{tabular}




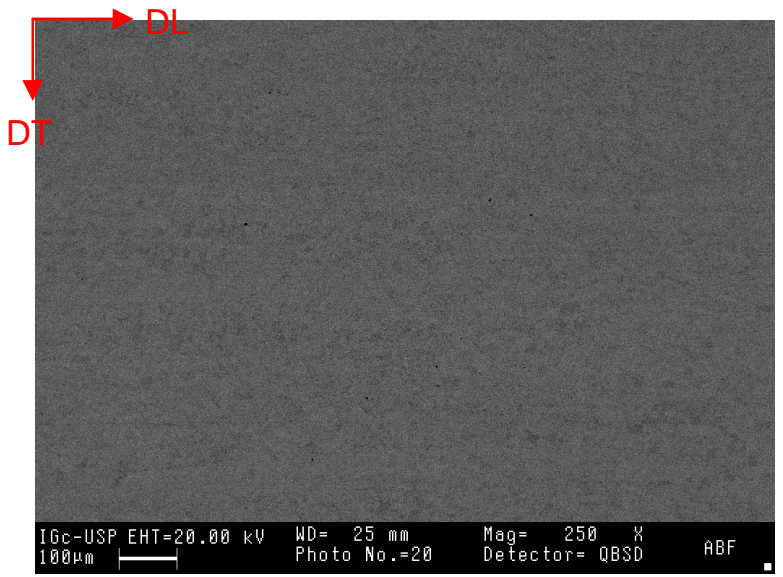

(a)

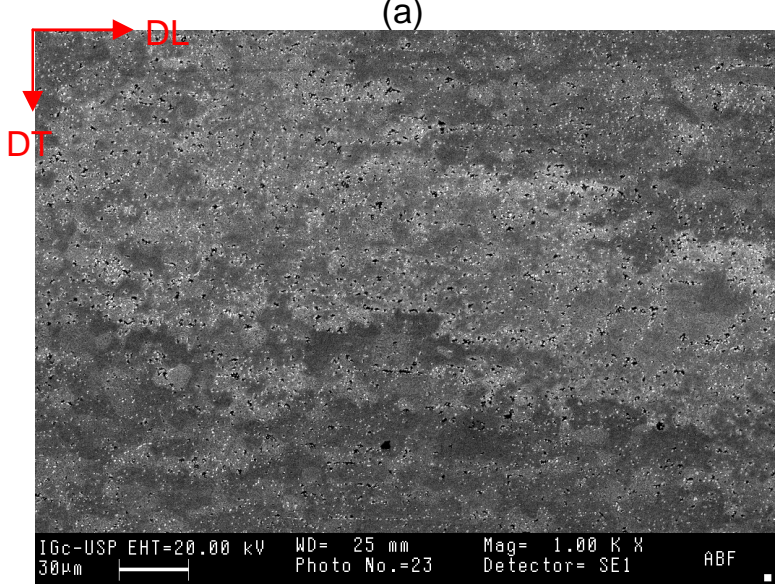

(c)

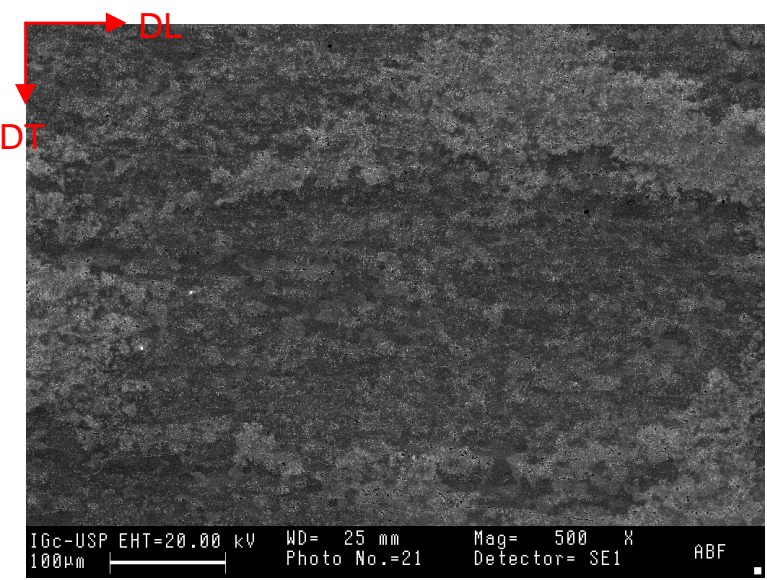

(b)

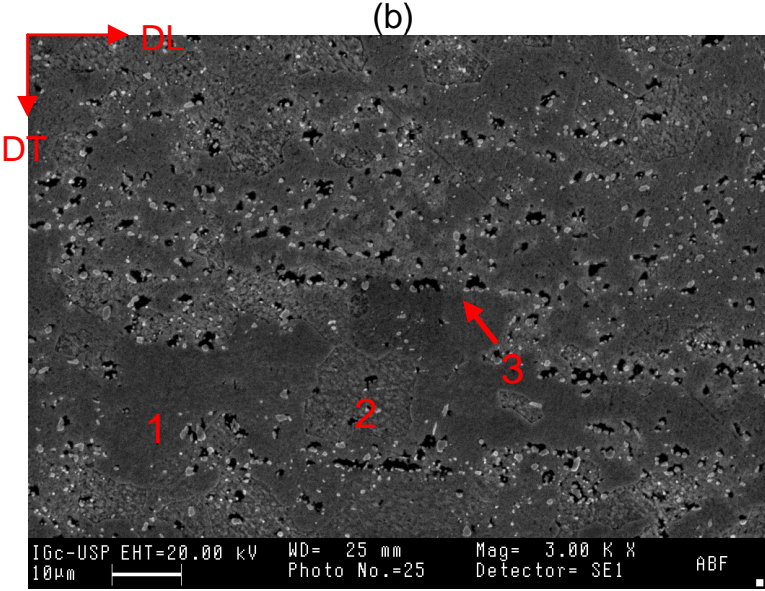

(d)

Figura 5.11: Aço AISI 430 na condição BFB. Micrografias em MEV, elétrons secundários com ataque por reagente Villela. Observa-se uma dispersão de carbonetos do tipo $\mathrm{M}_{23} \mathrm{C}_{6}$ (precipitado claro) e nitretos do tipo $(\mathrm{Cr}, \mathrm{Fe})_{2} \mathrm{~N}$ (precipitados escuros) em uma matriz ferrítica.

Com base nos resultados obtidos para o aço AISI 430 na condição BF recozido, observa-se uma matriz ferrítica de alto teor de cromo com presença de nitretos do tipo $(\mathrm{Cr}, \mathrm{Mo}, \mathrm{Ti}, \mathrm{Fe}){ }_{2} \mathrm{~N}$ ricos em $\mathrm{Cr}_{2} \mathrm{~N}$ e carbonetos do tipo $(\mathrm{Cr}, \mathrm{Fe})_{23} \mathrm{C}_{6}$. Os carbonetos e nitretos deste aço não estão concentrados nos contornos de grão como no aço AISI $430 \mathrm{BQB}$, provavelmente devido ao crescimento de grão após a recristalização durante o recozimento a $830^{\circ} \mathrm{C}$ por $28 \mathrm{~s}$.

\subsubsection{Condições tratadas termicamente}

\subsubsection{Condição $B Q B$ e tratado a $600^{\circ} \mathrm{C}$ por $5 \mathrm{~h}$}

$\mathrm{Na}$ figura 5.12 apresentam-se micrografias em MO com ataque com os reagentes de Kalling's 1 e Villela do aço AISI 430 na condição BQB e tratado a $600^{\circ} \mathrm{C} / 5 \mathrm{~h}$. Estas micrografias mostraram -se extremamente próximas as micrografias do aço AISI 430 na condição BQB, figura 5.8. Observa-se que houve um pequeno crescimento de grão, porém os carbonetos do tipo $(\mathrm{Cr}, \mathrm{Fe})_{23} \mathrm{C}_{6}$, estão 
preferencialmente dispersos nos contornos de grão. Os contornos de grão mostraram ataque preferencial devido ao menor teor de cromo devido à precipitação dos carbonetos do tipo $\mathrm{M}_{23} \mathrm{C}_{6}$ nos contornos (sensitização).

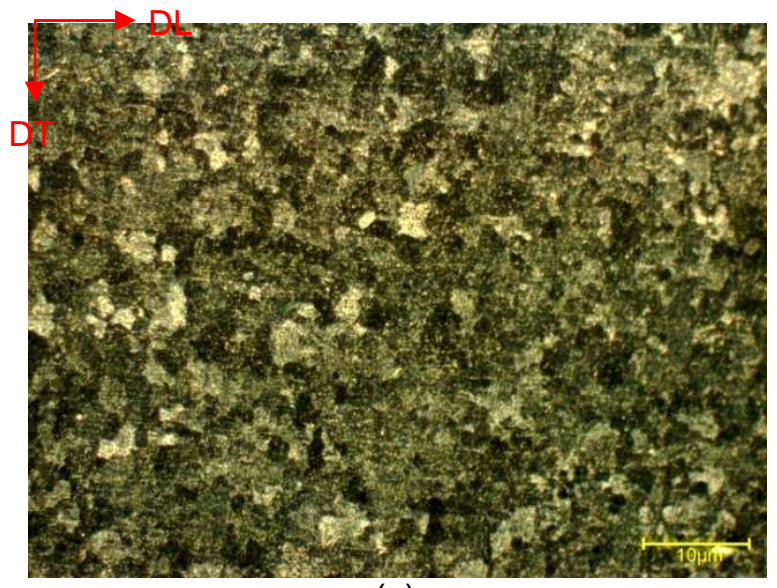

(a)

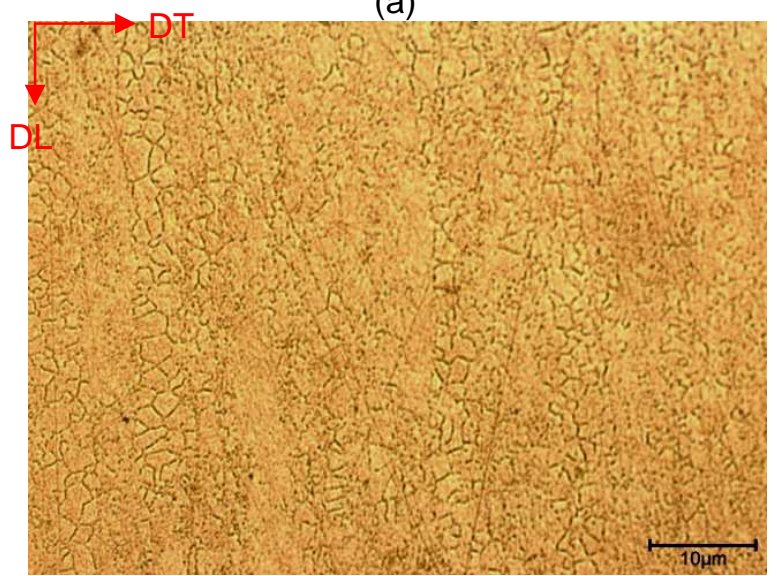

(c)

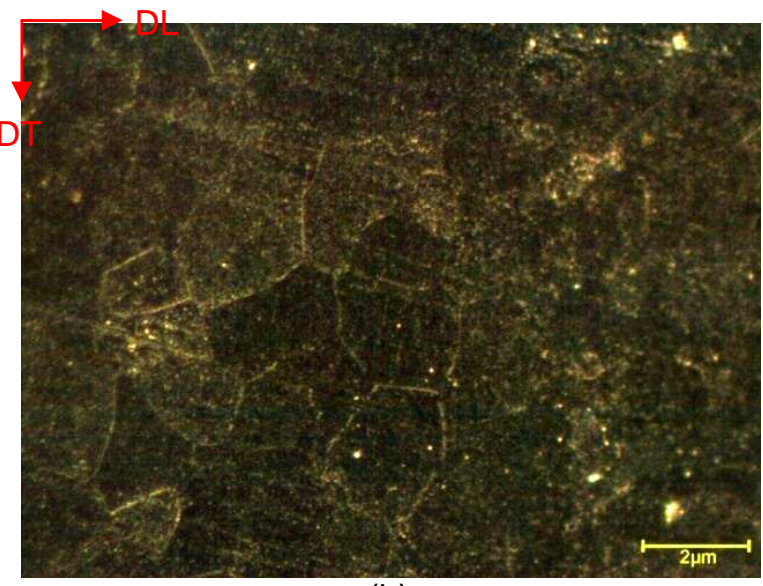

(b)

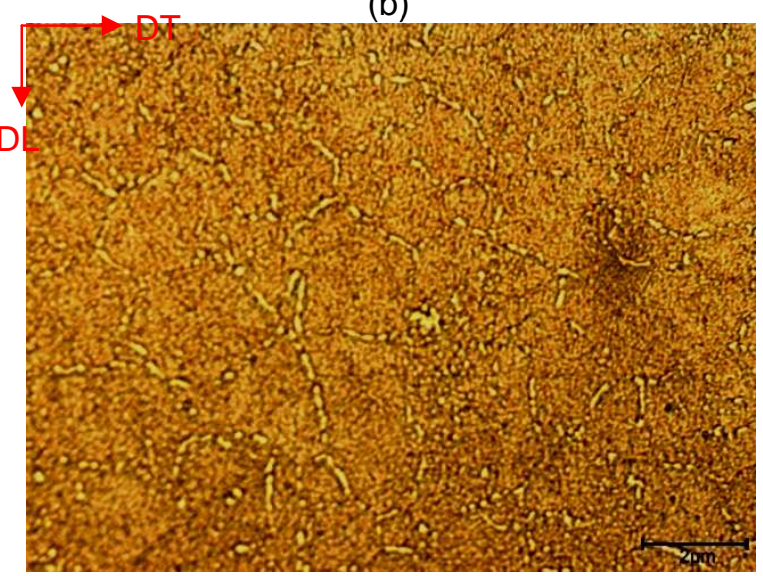

(d)

Figura 5.12: Aço AISI 430 na condição BQB e tratado a 600 $/ 5 \mathrm{~h}$. Micrografias em $\mathrm{MO}$.

Micrografias (a) e (b) ataque por reagente Kalling's 1, campo escuro. Micrografias (c) e (d) ataque por reagente Villela.

$\mathrm{O}$ aço AISI 430 na condição $\mathrm{BQB}$ e tratado a $600^{\circ} \mathrm{C} / 5 \mathrm{~h}$ apresenta matriz ferrítica com alto teor de cromo e dispersão de nitretos do tipo $(\mathrm{Cr}, \mathrm{Fe})_{2} \mathrm{~N}$ ricos em $\mathrm{Cr}_{2} \mathrm{~N}$ e de carbonetos do tipo $\mathrm{M}_{23} \mathrm{C}_{6}$, com picos de difração coincidindo com a ficha do carboneto com composição $\mathrm{Cr}_{15,58} \mathrm{Fe}_{7,72} \mathrm{C}_{6}$. Foi verificado ataque preferencial nos contornos de grão devido à redução do teor de cromo destes em função da precipitação dos carbonetos do tipo $\mathrm{M}_{23} \mathrm{C}_{6}$. Do difratograma dos precipitados extraídos foi verificada a possibilidade de dispersão de carbonitretos do tipo Ti(C,N). A microestrutura do aço AISI 430 na condição $B Q B$ e tratado a $600^{\circ} \mathrm{C} / 5 \mathrm{~h}$ mostrou -se quase idêntica a da condição BQB (como recebida), indicando que não houve alterações significativas na microestrutura após o tratamento térmico a $600{ }^{\circ} \mathrm{C} / 5 \mathrm{~h}$. 


\subsubsection{Condição $B Q B$ e tratado a $700^{\circ} \mathrm{C}$ por $5 \mathrm{~h}$}

$\mathrm{Na}$ figura 5.13 apresentam-se micrografias em $\mathrm{MO}$ com ataque pelos reagentes Villela e Kalling's 1 do aço AISI 430 na condição BQB e tratado a $700^{\circ} \mathrm{C} / 5 \mathrm{~h}$.Comparando- se as micrografias da figura $5.13 \mathrm{com}$ as micrografias da figura 5.8 (condição BQB) observa-se que o tratamento térmico a $700^{\circ} \mathrm{C} / 5 \mathrm{~h}$ não trouxe alterações significativas à microestrutura.

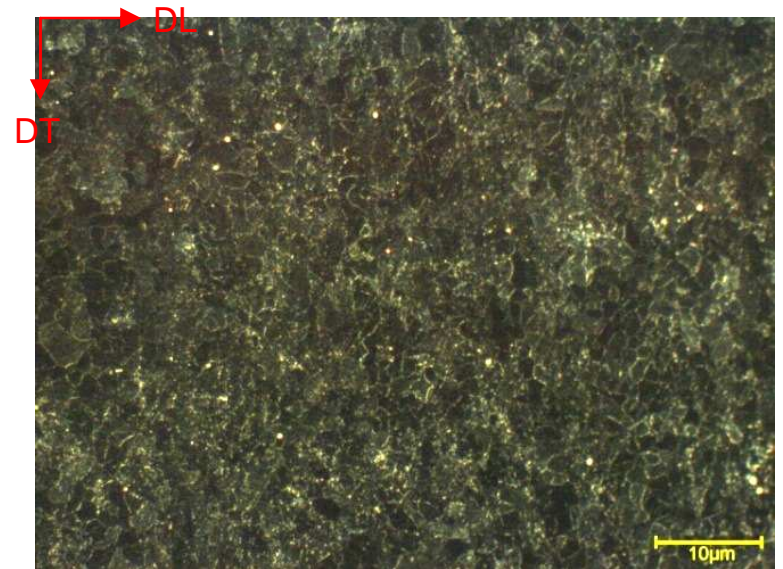

(a)

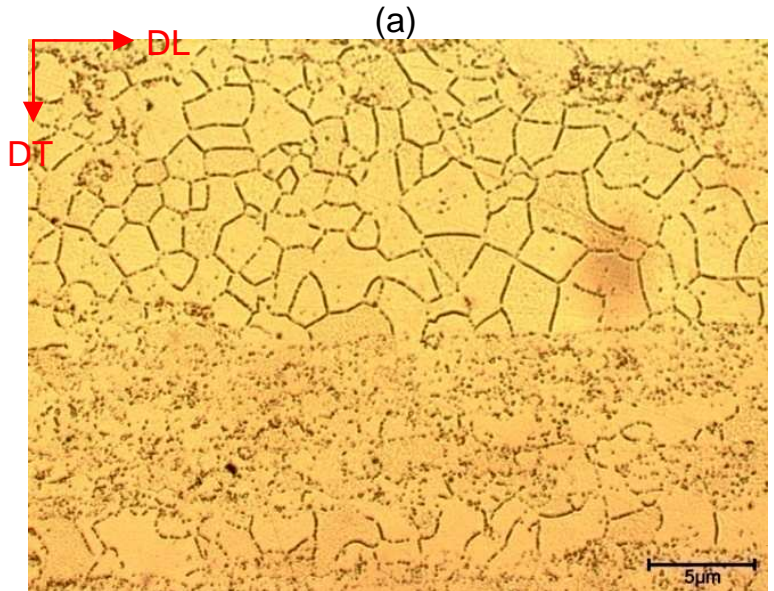

(c)

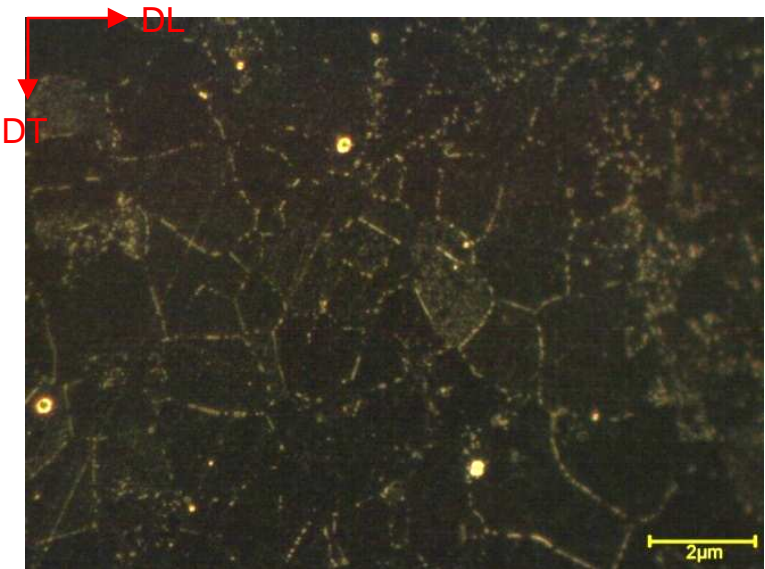

(b)

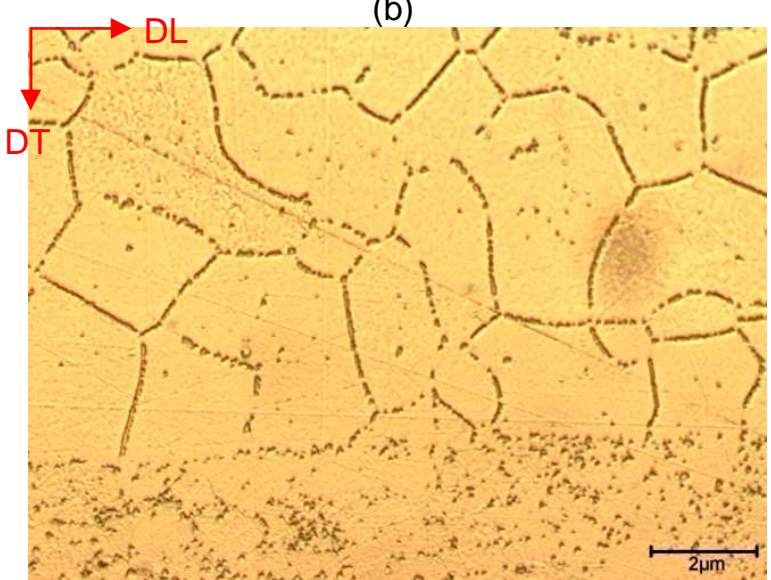

(d)

Figura 5.13: Aço AISI 430 na condição $B Q B$ e tratado a $700^{\circ} \mathrm{C} / 5 \mathrm{~h}$. Micrografias em $\mathrm{MO}$.

Micrografias (a) e (b) ataque por reagente Kalling's 1, campo escuro. Micrografias (c) e (d) ataque por reagente Villela.

Observa-se na figura 5.13(c) uma maior fração recristalizada dos grãos em relação à amostra $\mathrm{BQB}$, bem como uma maior quantidade de precipitados nos contornos dos grãos de carbonetos do tipo $\mathrm{M}_{23} \mathrm{C}_{6}$, identificados pela difração de raios-X dos precipitados extraídos. No entanto, assim como na amostra BQB, observa-se que há regiões recristalizadas e regiões não recristalizadas, indicando uma possível diferença de textura entre estas regiões em acordo com o trabalho de Sinclair et al. ${ }^{(19)}$.

Nas micrografias em MEV da figura 5.14 observa-se que os carbonetos do 
tipo $\mathrm{M}_{23} \mathrm{C}_{6}$ estão presentes preferencialmente nos contornos de grão. Dada a diferença de ataque, observa-se que a matriz é composta por dois tipos de ferrita com teores de cromo ligeiramente diferentes (regiões 2 e 3 da figura 5.14(d)) indicando possível segregação de $\mathrm{Cr}$ entre os dois tipos de ferrita, assim como indicado na análise química via EDS apresentada na tabela 5.7. No entanto como o erro da análise por EDS é da ordem de 0,5\% para o cromo, não pode-se afirmar com certeza a presença de segregação de cromo entre os dois tipos de ferrita por esta análise química. Entretanto, $A$ análise dos padrões de DR-X da matriz permite que seja inferida esta segregação visto que a amostra de partida (condição BQB) apresenta dois tipos de ferrita com dois parâmetros de rede diferentes, e devido a baixa difusividade do $\mathrm{Cr}$ a $700^{\circ} \mathrm{C}$, a segregação de c romo possa ter sido mantida mesmo com a amostra sendo submetida a um tratamento térmico $7000^{\circ} \mathrm{C}$ por $5 \mathrm{~h}$.

Tabela 5.7: Análise química via EDS (\% em peso) do aço AISI 430 na condição BQB e tratado a $700^{\circ} \mathrm{C} / 5 \mathrm{~h}$, referente à micrografia da figura $5.14(\mathrm{~d})$.

\begin{tabular}{|c|c|c|c|c|c|c|}
\hline Ponto & Fase & $\mathbf{C}$ & $\mathbf{C r}$ & $\mathbf{M n}$ & $\mathbf{F e}$ & Si \\
\hline $\mathbf{1}$ & Carboneto & Identificado & 17,4 & 0,8 & 81,7 & --- \\
\hline $\mathbf{2}$ & Matriz clara & --- & 16,4 & --- & 83,2 & 0,4 \\
\hline $\mathbf{3}$ & Matriz escura & --- & 16,5 & 0,8 & 82,3 & 0,4 \\
\hline
\end{tabular}

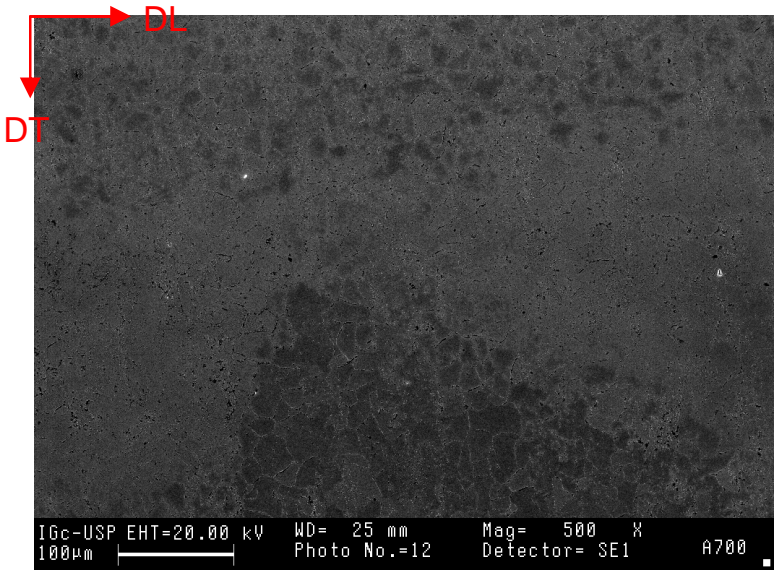

(a)

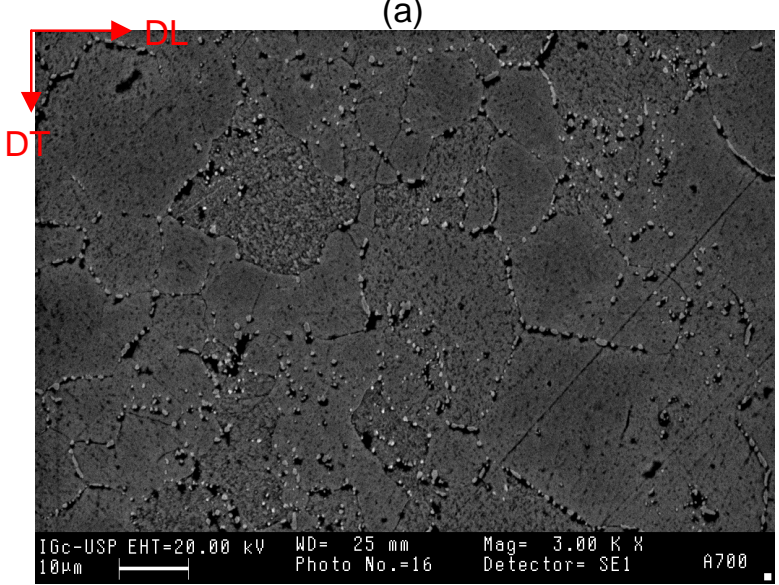

(c)

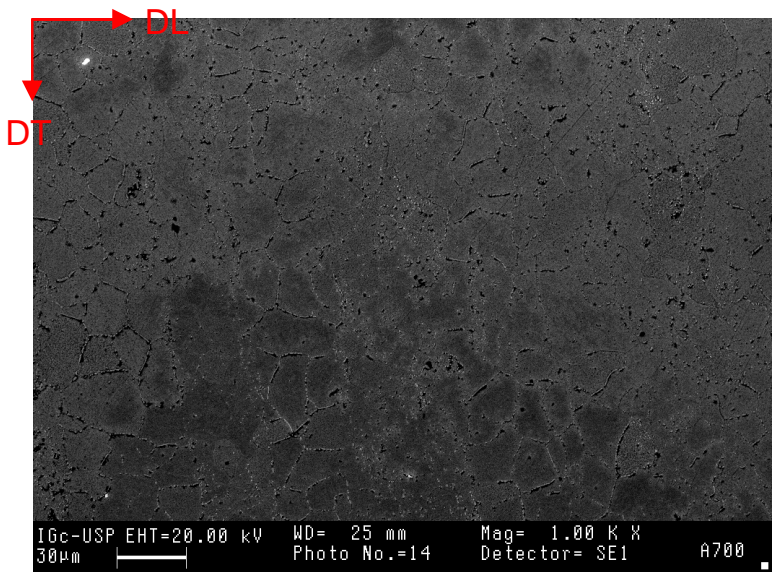

(b)

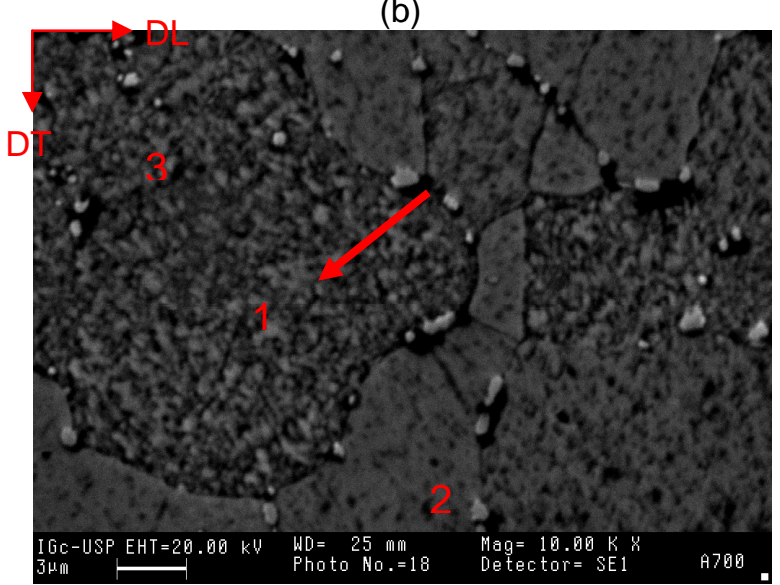

(d)

Figura 5.14: Aço AISI 430 na condição BQB e tratado a $700{ }^{\circ} \mathrm{C}$ por 5h. Micrografias em MEV, elétrons secundários, com ataque por reagente Villela. 
O aço AISI 430 na condição $B Q B$ e tratado a $700^{\circ} \mathrm{C} / 5 \mathrm{~h}$ apresenta matriz ferrítica com alto teor de cromo e a presença de nitretos do tipo $(\mathrm{Cr}, \mathrm{Fe})_{2} \mathrm{~N}$ ricos em $\mathrm{Cr}_{2} \mathrm{~N}$ e de carbonetos do tipo $(\mathrm{Cr}, \mathrm{Fe})_{23} \mathrm{C}_{6}$. Foi verificado ataque preferencial nos contornos de grão, indicando a possibilidade de dissolução parcial dos carbonetos e nitretos durante o tratamento térmico e posterior re-precipitação, empobrecendo os contornos de grão em $\mathrm{Cr}$, e conseqüentemente tornando-os suscetíveis à corrosão. A microestrutura da amostra do aço $\mathrm{AISI} 430$ na condição $\mathrm{BQB}$ e tratado a $700^{\circ} \mathrm{C} / 5 \mathrm{~h}$ mostrou-se muito próxima a da condição $B Q B$, indicando que houve poucas alterações significativas na microestrutura após o tratamento térmico a $700{ }^{\circ} \mathrm{C} / 5 \mathrm{~h}$.

\subsubsection{Condição $B Q B$ e tratado a $800^{\circ} \mathrm{C}$ por $5 \mathrm{~h}$}

$\mathrm{Na}$ figura 5.15 apresentam-se micrografias em $\mathrm{MO}$ com ataque com reagente Villela do aço AISI 430 na condição BQB e tratado a 800ㄷ/5h. Nestas micrografias, observa-se que houve um pequeno crescimento de grão em relação a amostra tratada a $700^{\circ} \mathrm{C}$ aliado a dissolução parcial dos carbonetos. Observado a micrografia da figura 5.15(b) verifica-se que o filme quase contínuo de carbonetos do tipo $\mathrm{M}_{23} \mathrm{C}_{6}$ que revestia os grãos (precipitados intergranulares) foi parcialmente dissolvido, sendo que os carbonetos encontram-se parcialmente esferoidizados e coalescidos.

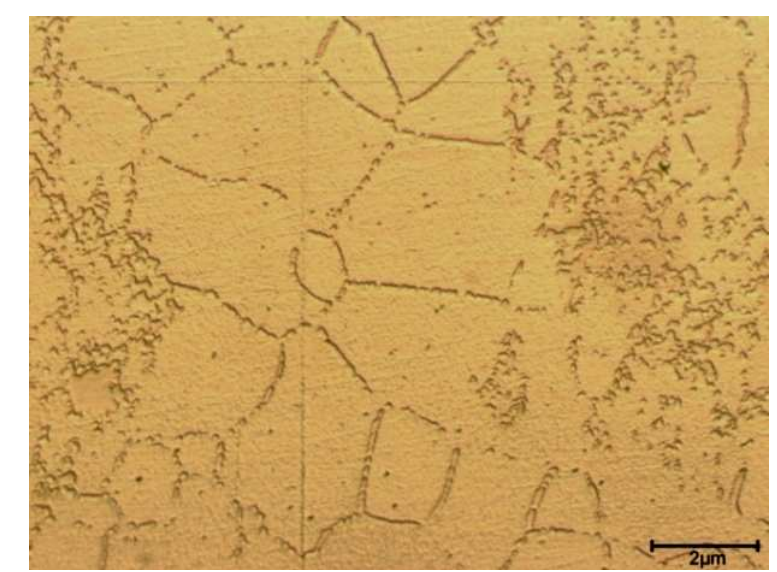

(a)

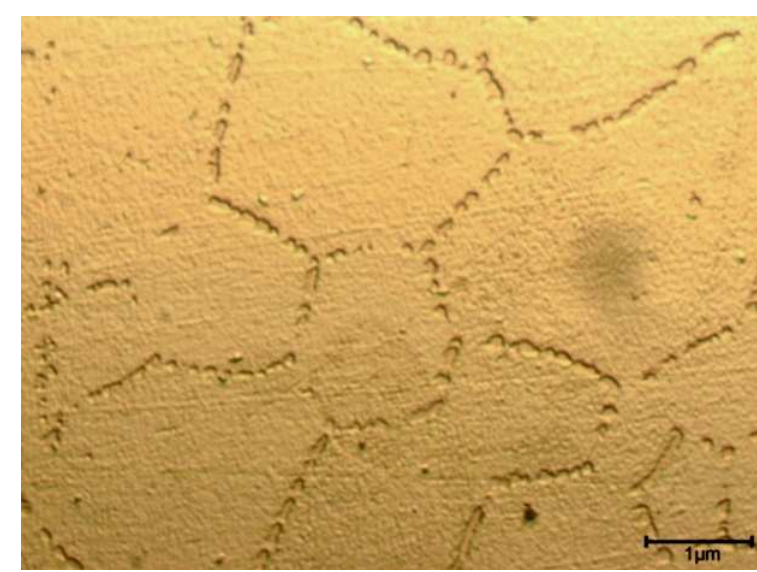

(b)

Figura 5.15: Aço AISI 430 na condição $B Q B$ e tratado a $800^{\circ} \mathrm{C} / 5 \mathrm{~h}$. Micrografias em $\mathrm{MO}$ com ataque por reagente Villela. Observam-se carbonetos do tipo $\mathrm{M}_{23} \mathrm{C}_{6}$ decorando os contornos de grão em uma matriz ferrítica.

A amostra do aço AISI 430 na condição BQB e tratado a $800{ }^{\circ} \mathrm{C} / 5 \mathrm{~h}$ apresentou uma matriz dúplex com presença de grão da fase martensita em uma matriz ferrítica. Foi verificada a presença de nitretos do tipo $(\mathrm{Cr}, \mathrm{Fe})_{2} \mathrm{~N}$ ricos em $\mathrm{Cr}_{2} \mathrm{~N}$ via difração de 
raios-X dos precipitados extraídos e a presença do carboneto do tipo $(\mathrm{Cr}, \mathrm{Fe})_{23} \mathrm{C}_{6}$ foi verificada tanto por difração de raios- $X$ dos precipitados quanto por metalografia. Foi observado crescimento de grão em relação a amostra tratada a $700^{\circ} \mathrm{C} / 5 \mathrm{~h}$. Houve provável dissolução de precipitados dada a redução do teor de carboneto do tipo $\mathrm{M}_{23} \mathrm{C}_{6}$ e posterior re-precipitação em carbonetos mais finos.

\subsubsection{Condição $B Q B$ e tratado a $900^{\circ} \mathrm{C}$ por $5 \mathrm{~h}$}

$\mathrm{Na}$ figura 5.16 são apresentadas micrografias em MO do aço AISI 430 na condição $\mathrm{BQB}$ e tratado a $900^{\circ} \mathrm{C} / 5 \mathrm{~h}$ onde se observa que a microestrutura é dúplex, e segundo as micrografias das figuras 5.16(a) e (b) é ferrítica/martensítica (grãos escuros são da fase ferrita e grãos claros são da fase martensita).

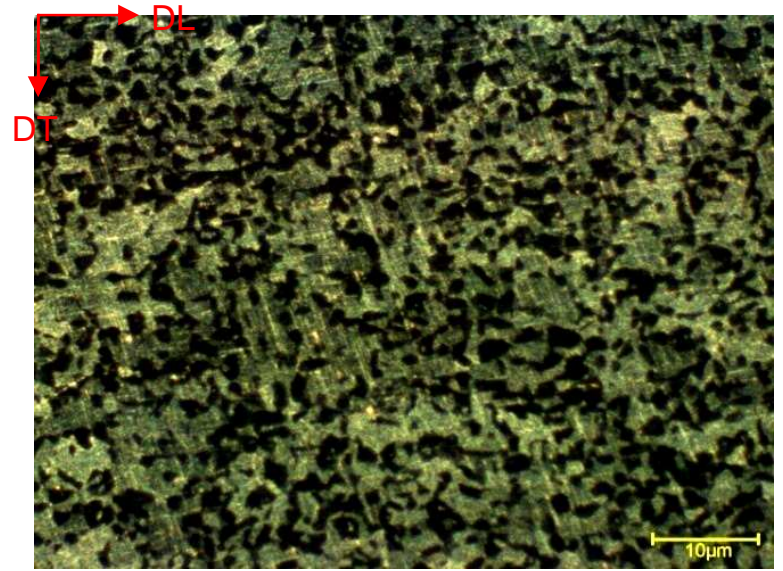

(a)

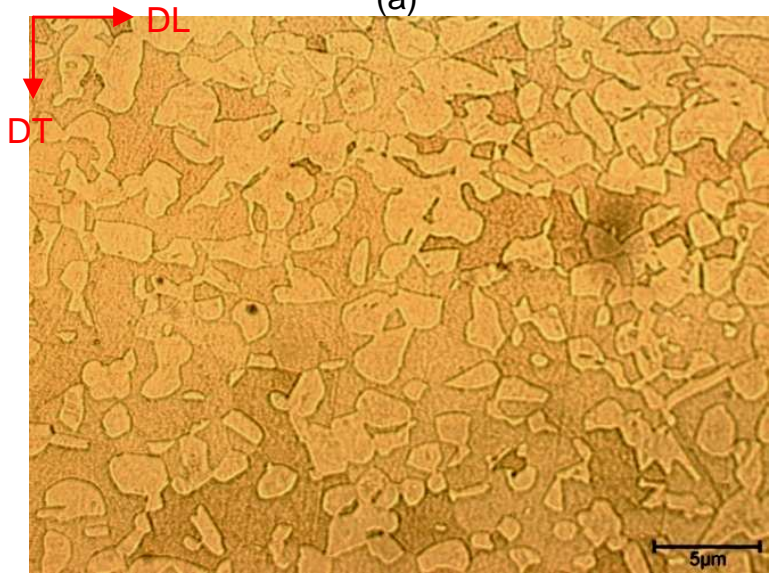

(c)

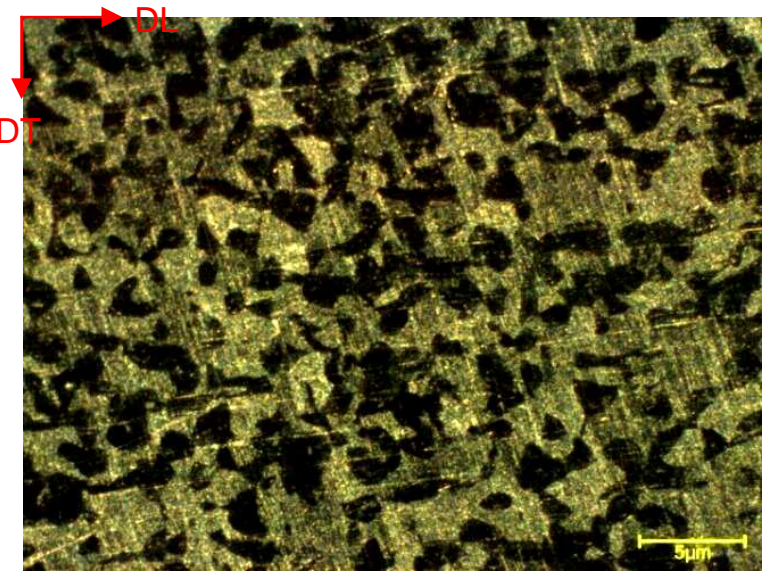

(b)

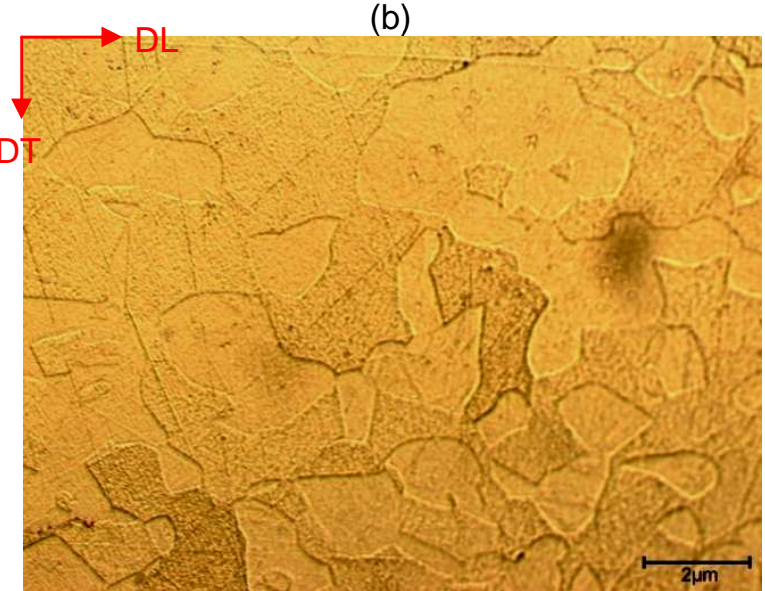

(d)

Figura 5.16: Aço AISI 430 na condição BQB e tratado a $900{ }^{\circ} \mathrm{C} / 5 \mathrm{~h}$. Micrografias em MO. Micrografias (a) e (b) ataque por reagente Kalling's 1, campo escuro. Micrografias (c) e (d) ataque por reagente Villela.

Na figura 5.17 são apresentadas micrografias em MEV obtidas com elétrons retro-espalhados e sem ataque do aço AISI 430 na condição BQB e tratado a 
$900^{\circ} \mathrm{C} / 5 \mathrm{~h}$. Estas micrografias mostram uma pequena va riação composicional entre as fases ferrita e martensita. Na tabela 5.8 é apresentada a análise química via EDS-MEV da micrografia da figura 5.17(c).

Tabela 5.8: Análise química via EDS (\% em peso) do aço AISI 430 na condição BQB e tratado a $900^{\circ} \mathrm{C} / 5 \mathrm{~h}$, referente à micrografia da figura 5.17 (c) .

\begin{tabular}{|c|c|c|c|c|c|c|c|}
\hline Ponto & Fase & N & $\mathbf{O}$ & $\mathbf{S i}$ & $\mathbf{C r}$ & $\mathbf{F e}$ & $\mathbf{M n}$ \\
\hline $\mathbf{1}$ & Matriz escura & Ident. & 2,8 & 0,4 & 16,4 & 79,0 & --- \\
\hline $\mathbf{2}$ & Matriz clara & Ident. & 1,7 & 0,3 & 15,6 & 80,7 & 0,4 \\
\hline
\end{tabular}

As análises químicas realizadas por EDS, tabela 5.8, indicam teores de O e N que não foram omitidos do fechamento dos dados visto que estes representam a possibilidade de uma leve oxidação da amostra durante o tratamento térmico, bem como a presença de precipitados finos na matriz do tipo $\mathrm{Cr}_{2} \mathrm{~N}$ identificados na difração de raios- $X$ dos precipitados extraídos.

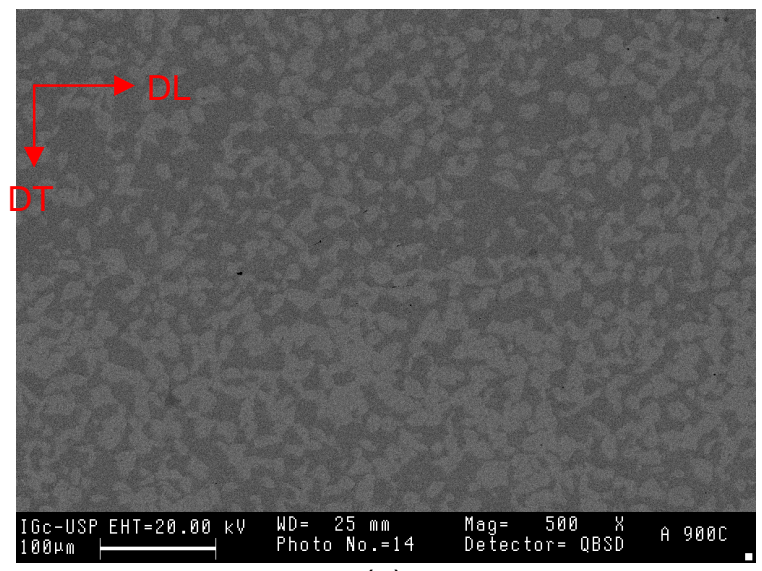

(a)

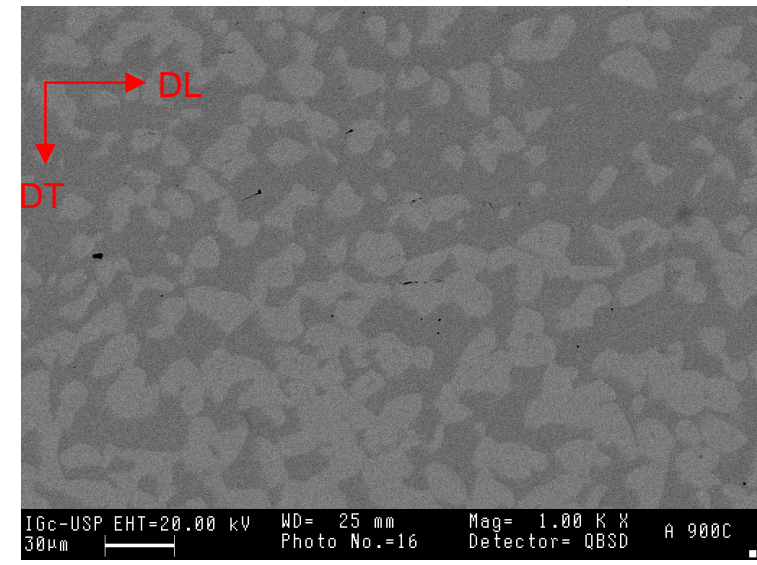

(b)

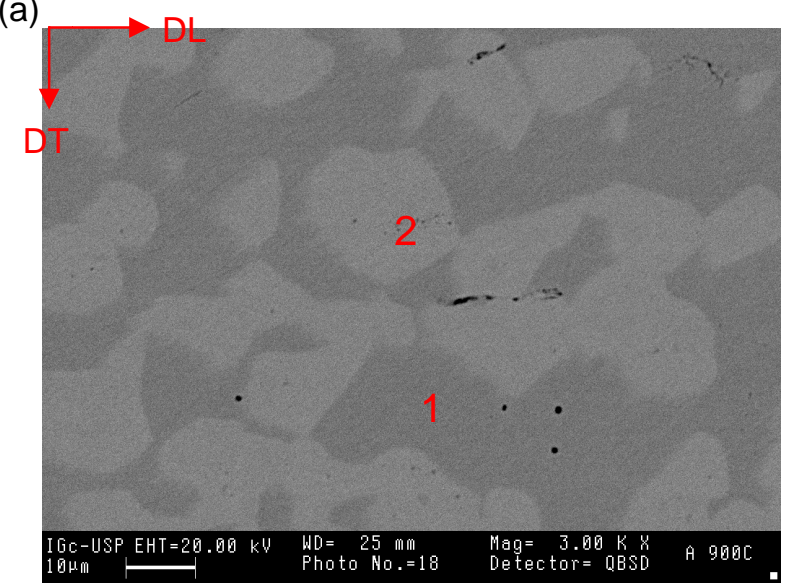

(c)

Figura 5.17: Aço AISI 430 na condição BQB e tratado a $900^{\circ} \mathrm{C}$ por $5 \mathrm{~h}$. Micrografias em MEV sem ataque. Aço com matriz bifásica (ferrita + martensita).

O aço AISI 430 na condição BQB e tratado a $900^{\circ} \mathrm{C} / 5 \mathrm{~h}$ apresentou uma matriz dúplex com dispersão de martensita em matriz ferrítica. Há presença de nitretos do tipo $(\mathrm{Cr}, \mathrm{Fe})_{2} \mathrm{~N}$ ricos em $\mathrm{Cr}_{2} \mathrm{~N}$ e há traços de carboneto do tipo $(\mathrm{Cr}, \mathrm{Fe})_{23} \mathrm{C}_{6}$. 
Foi observado crescimento de grão em relação à amostra tratada a $800{ }^{\circ} \mathrm{C} / 5 \mathrm{~h}$.

\subsubsection{Condição BQB e tratado a $1000^{\circ} \mathrm{C}$ por $5 \mathrm{~h}$}

$\mathrm{Na}$ figura 5.18 são apresentadas micrografias em MO do aço AISI 430 na condição BQB e tratado a $1000{ }^{\circ} \mathrm{C} / 5 \mathrm{~h}$ onde observa-se uma estrutura dúplex formada pela dispersão de fase martensita em uma matriz ferrítica. Observa-se na micrografia da figura 5.18(c) a presença de pequenos carbonetos do tipo $\mathrm{M}_{23} \mathrm{C}_{6}$. Observa-se que a martensita apresentou maior corrosão que a ferrita no ataque químico feito com reagente Villela, indicando que a martensita apresenta menor teor de cromo que a ferrita.

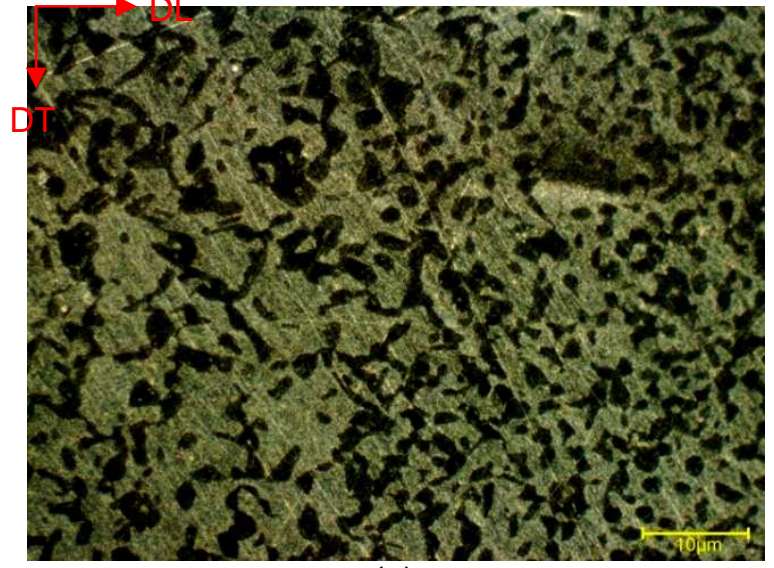

(a)

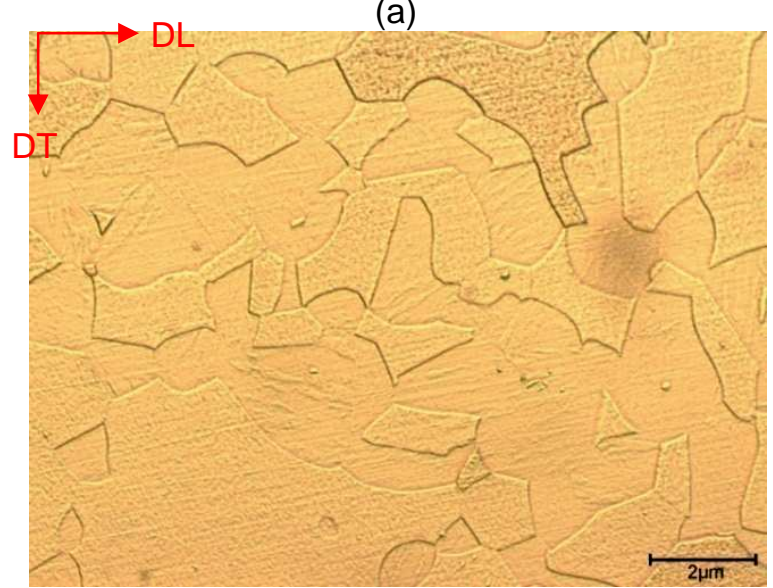

(c)

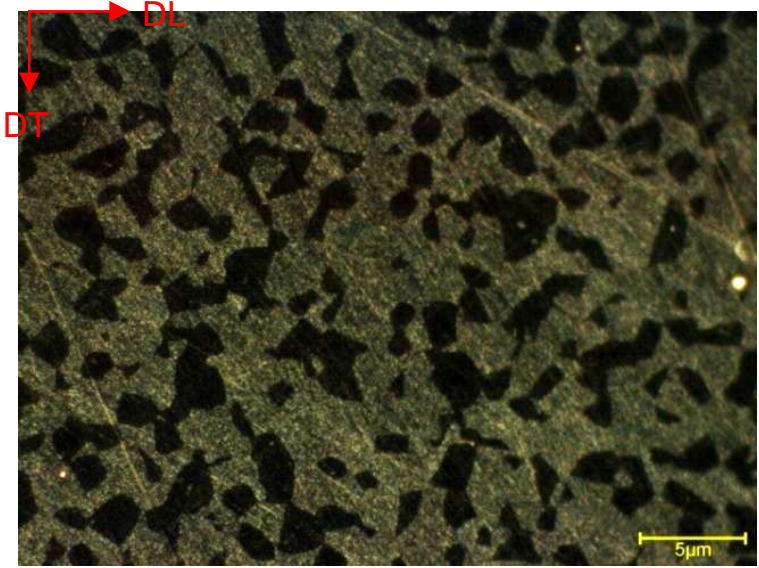

(b)

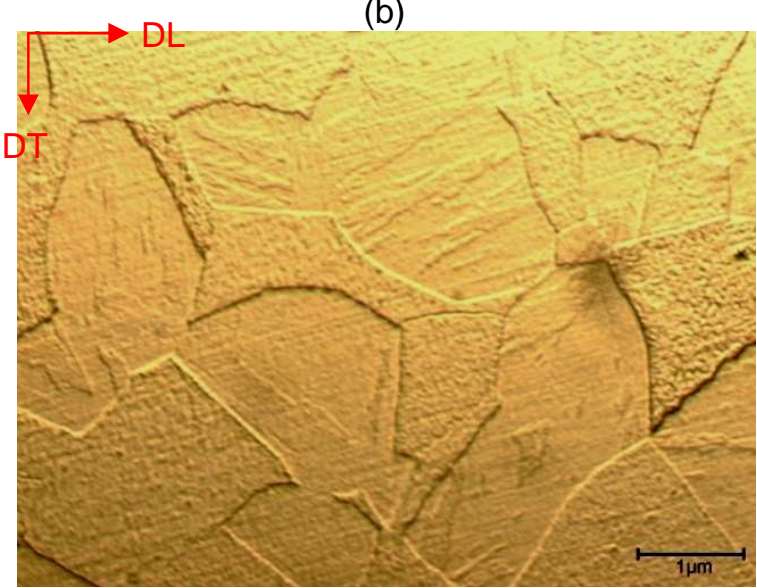

(d)

Figura 5.18: Aço AISI 430 na condição BQB e tratado a $1000^{\circ} \mathrm{C} / 5 \mathrm{~h}$. Micrografias em $\mathrm{MO}$. Micrografias (a) e (b) ataque por reagente Kalling's 1, campo escuro. Micrografias (c) e (d) ataque por reagente Villela. Observam-se ripas de martensita na figura (d), indicando claramente uma matriz bifásica ferrita/martensita.

Na figura 5.19 são apresentadas micrografias em MEV do aço AISI 430 na condição $\mathrm{BQB}$ e tratado a $10000^{\circ} \mathrm{C} / 5 \mathrm{~h}$. Estas micrografias revelam uma estrutura dúplex com dispersão de grãos de martensita em uma matriz ferrítica. Na tabela 5.9 
apresentam-se os resultados da análise química via EDS para a micrografia da figura 5.19(c).

Tabela 5.9: Análise química via EDS (\% em peso) do aço AISI 430 na condição BQB e tratado a $1000{ }^{\circ} \mathrm{C} / 5 \mathrm{~h}$, referente à micrografia da figura 5.19 (c).

\begin{tabular}{|c|c|c|c|c|c|c|}
\hline Ponto & Fase & $\mathbf{N}$ & $\mathbf{O}$ & $\mathbf{S i}$ & $\mathbf{C r}$ & $\mathbf{F e}$ \\
\hline $\mathbf{1}$ & Matriz escura & Ident. & 2,8 & 0,4 & 17,1 & 78,7 \\
\hline $\mathbf{2}$ & Matriz clara & Ident. & 1,8 & 0,3 & 15,5 & 81,2 \\
\hline
\end{tabular}

O aço AISI 430 na condição BQB e tratado a $1000{ }^{\circ} \mathrm{C} / 5 \mathrm{~h}$ apresentou uma matriz dúplex com dispersão de martensita em uma matriz ferrítica. Foi verificada a presença de nitretos do tipo $(\mathrm{Cr}, \mathrm{Fe})_{2} \mathrm{~N}$ ricos em $\mathrm{Cr}_{2} \mathrm{~N}$ e traços de carboneto do tipo $(\mathrm{Cr}, \mathrm{Fe})_{23} \mathrm{C}_{6}$ observados por $\mathrm{MO}$. Verificou-se crescimento de grão em relação à amostra tratada a $900^{\circ} \mathrm{C} / 5 \mathrm{~h}$.

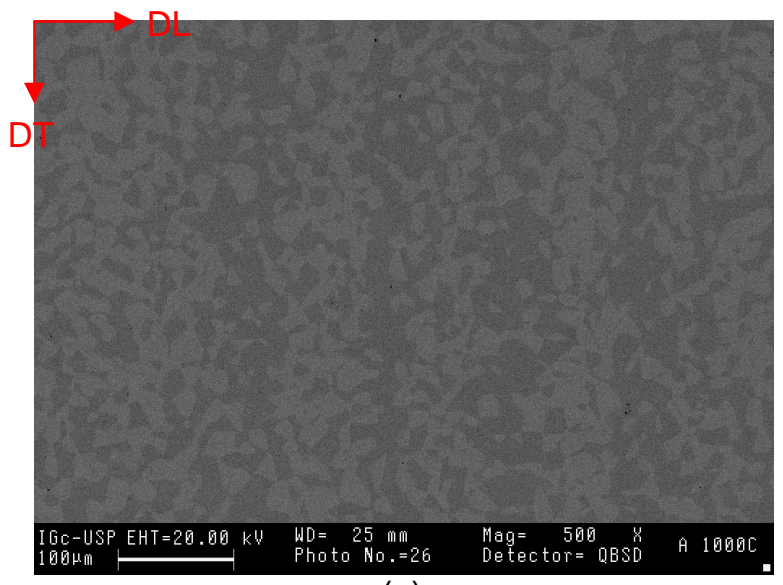

(a)

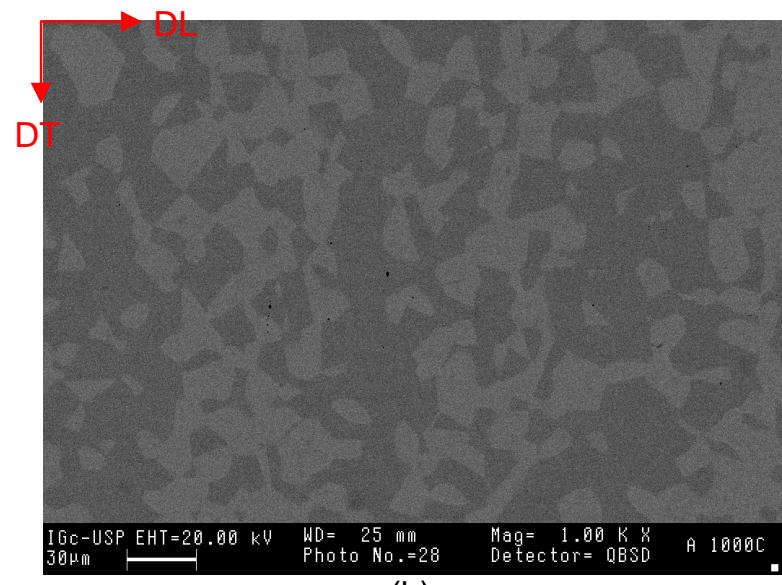

(b)

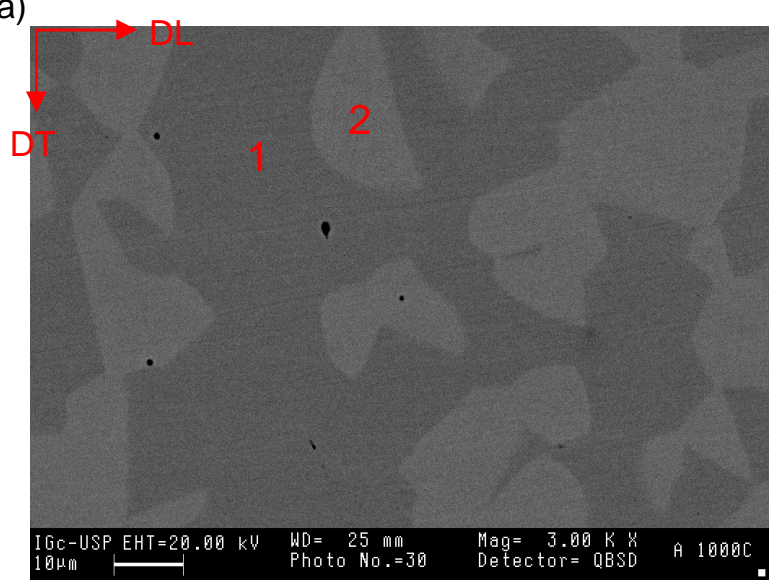

(c)

Figura 5.19: Aço AISI 430 na condição $B Q B$ e tratado a $1000^{\circ} \mathrm{C}$ por 5 h. Micrografias em MEV sem ataque.

\subsubsection{Condição $B Q B$ e tratado a $1100{ }^{\circ} \mathrm{C}$ por $5 \mathrm{~h}$}

$\mathrm{Na}$ figura 5.20 apresentam-se micrografias em MO do aço AISI 430 na condição $B Q B$ e tratado a $1100^{\circ} \mathrm{C} / 5 \mathrm{~h}$ onde se observa que o aço AISI 430 na 
condição BQB e tratado a $1100^{\circ} \mathrm{C} / 5 \mathrm{~h}$ apresenta uma es trutura dúplex formada por uma dispersão de martensita em uma matriz ferrítica. Não foi verificada por $\mathrm{MO}$ a presença de carbonetos e precipitados na microestrutura. Observa-se que a martensita apresentou maior corrosão que a ferrita no ataque químico feito com reagente Villela, indicando que a martensita apresenta menor teor de cromo que a ferrita.

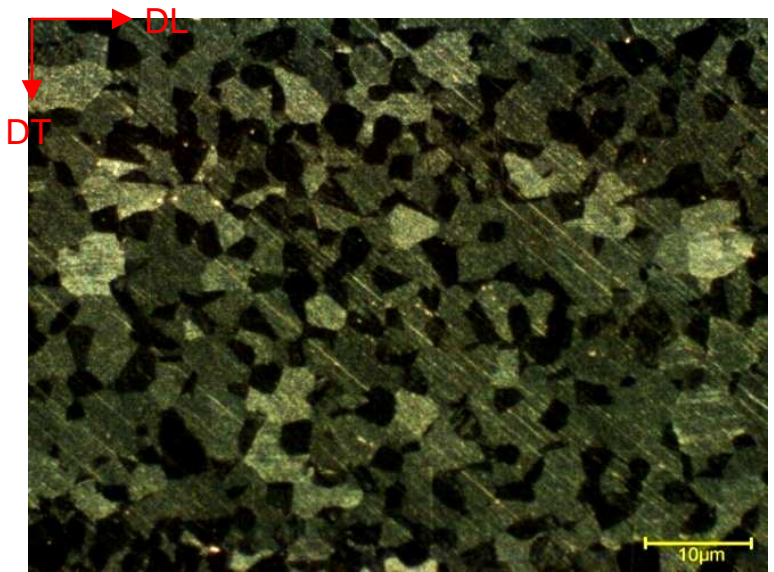

(a)

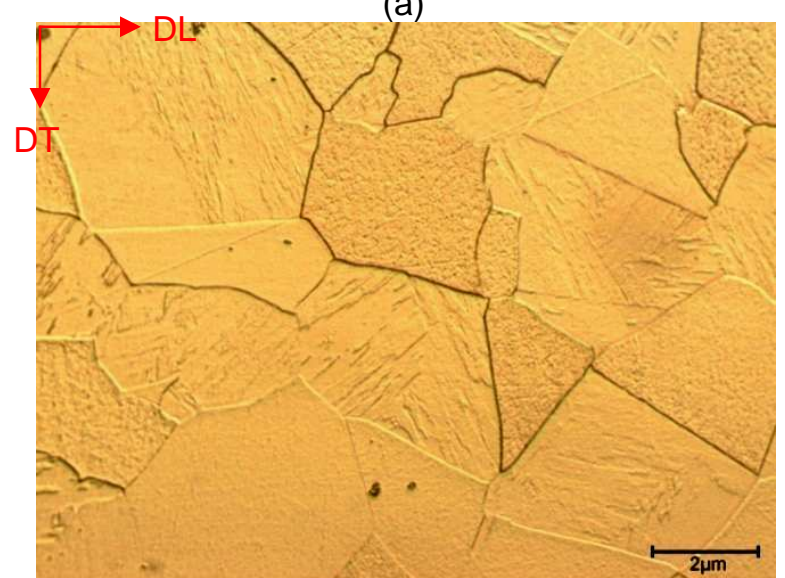

(c)

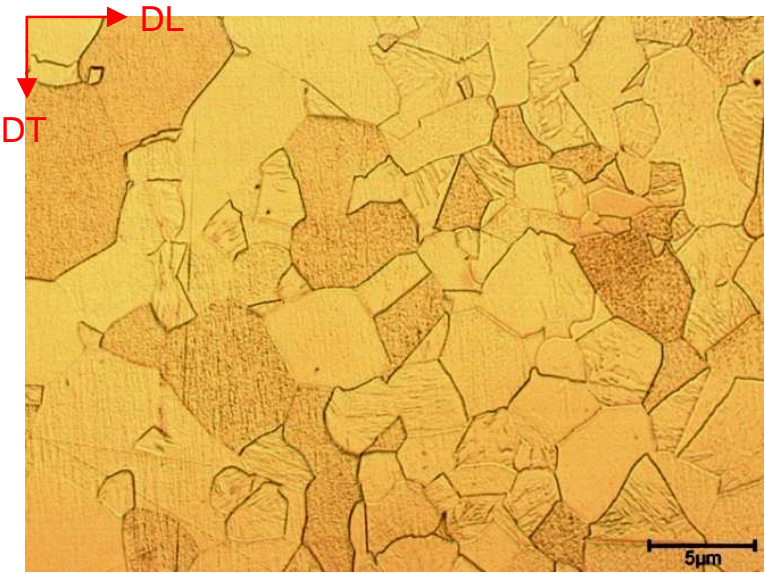

(b)

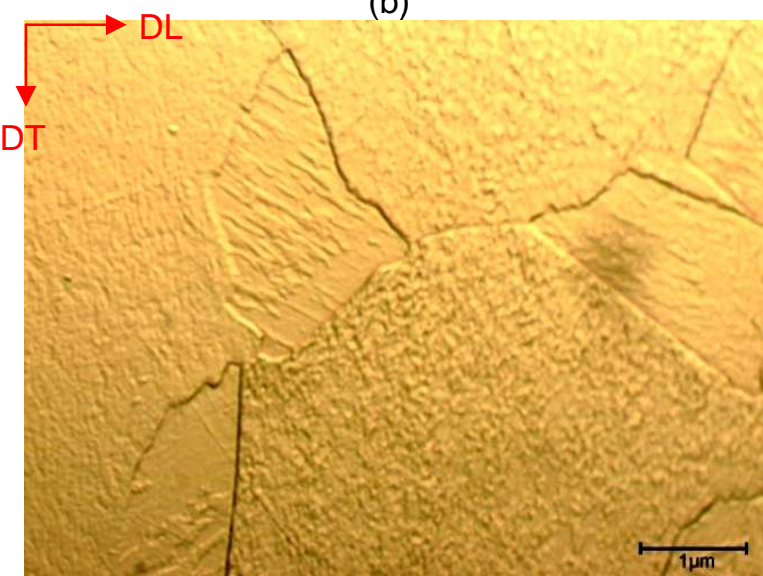

(d)

Figura 5.20: Aço AISI 430 na condição BQB e tratado a $1100{ }^{\circ} \mathrm{C} / 5 \mathrm{~h}$. Micrografias em MO.

Micrografia (a) ataque por reagente Kalling's 1, campo escuro. Micrografias (b), (c) e (d) ataque por reagente Villela. Observam-se ripas de martensita na figura (d), indicando claramente uma matriz bifásica ferrita/martensita.

$\mathrm{Na}$ figura 5.21 são apresentadas micrografias em MEV sem ataque do aço AISI 430 na condição $B Q B$ e tratado a $1100^{\circ} \mathrm{C} / 5$ h onde se observa uma estrutura dúplex com dispersão de grãos de martensita em uma matriz ferrítica. $\mathrm{Na}$ tabela 5.10 apresentam-se os resultados da análise química via EDS para a micrografia da figura $5.21(\mathrm{c})$. 
Tabela 5.10: Análise química via EDS (\% em peso) do aço AISI 430 na condição BQB e tratado a $1100 \mathrm{C} / 5 \mathrm{~h}$, referente à micrografia da figura 5.21 (c ).

\begin{tabular}{|c|c|c|c|c|c|c|}
\hline Ponto & Fase & $\mathbf{N}$ & $\mathbf{O}$ & $\mathbf{S i}$ & $\mathbf{C r}$ & $\mathbf{F e}$ \\
\hline $\mathbf{1}$ & Matriz escura & Ident. & 2,9 & 0,4 & 16,6 & 78,7 \\
\hline $\mathbf{2}$ & Matriz clara & Ident. & 1,9 & 0,4 & 15,6 & 81,0 \\
\hline
\end{tabular}

O aço AISI 430 na condição BQB apresenta matriz dúplex com dispersão de martensita em matriz ferrítica. Foi verificada por difração de raios- $X$ dos precipitados a presença de nitretos do tipo $(\mathrm{Cr}, \mathrm{Fe})_{2} \mathrm{~N}$ ricos em $\mathrm{Cr}_{2} \mathrm{~N}$ e traços de carboneto do tipo $(\mathrm{Cr}, \mathrm{Fe})_{23} \mathrm{C}_{6}$. Observou-se crescimento de grão em relação a amostra tratada a $900^{\circ} \mathrm{C} / 5 \mathrm{~h}$.

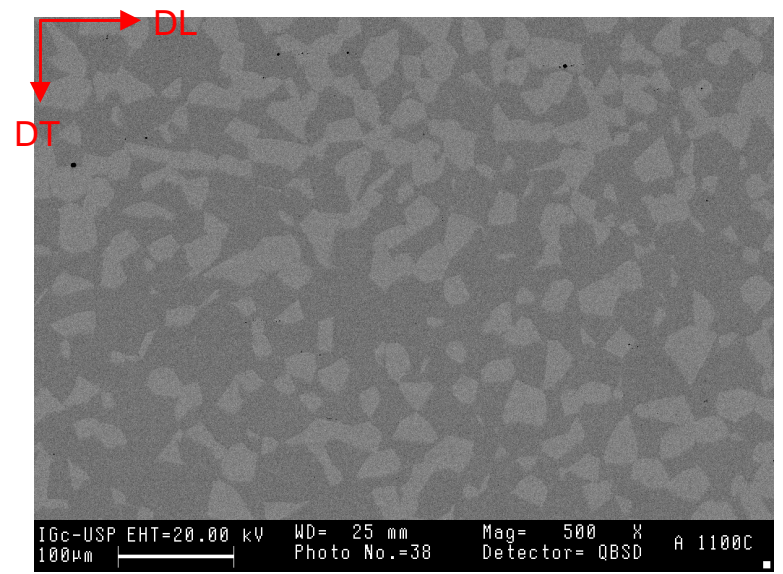

(a)

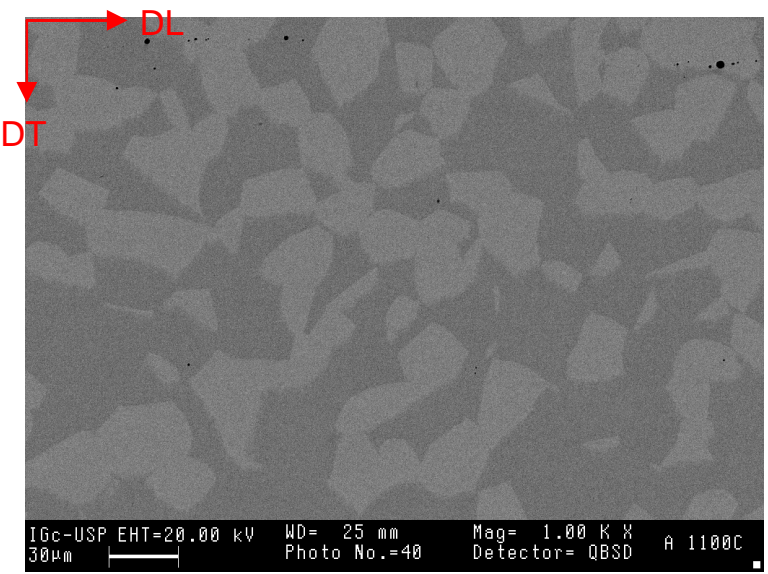

(b)

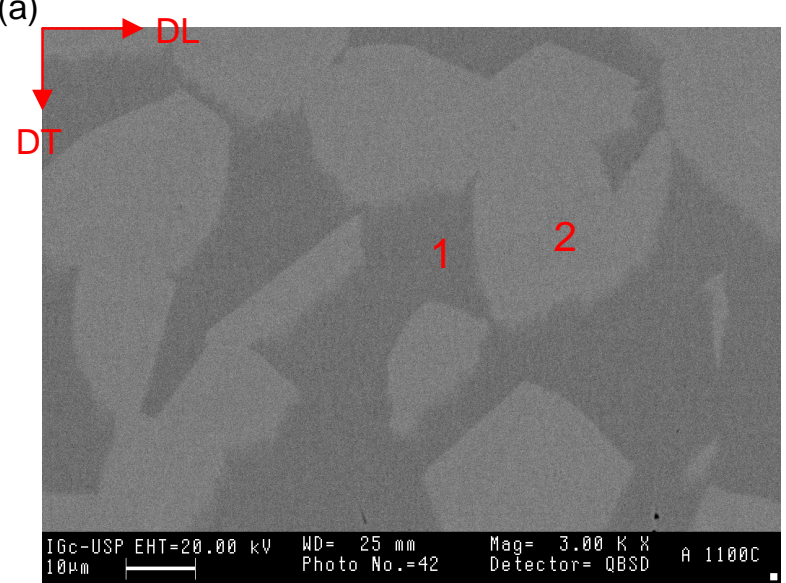

(c)

Figura 5.21: Aço AISI 430 na condição BQB e tratado a $1100{ }^{\circ} \mathrm{C}$ por 5h. Micrografias em MEV sem ataque.

\subsection{Análise térmica diferencial (DTA)}

Foi realizado um ensaio de DTA no aço AISI 430, na condição BQ Recozido, seguindo o ciclo térmico apresentado no item 4.6. Na figura 5.22 apresenta-se um gráfico ilustrando o ciclo térmico do ensaio de DTA da amostra do aço AISI 430 na condição BQB.

Do ensaio de DTA foi obtido o gráfico da figura 5.23 , onde se apresenta a 
diferença de potencial em relação à alumina $($ DTA $[\mu \mathrm{V}])$ e a temperatura $\left[{ }^{\circ} \mathrm{C}\right]$ em função do tempo [min] do ensaio.

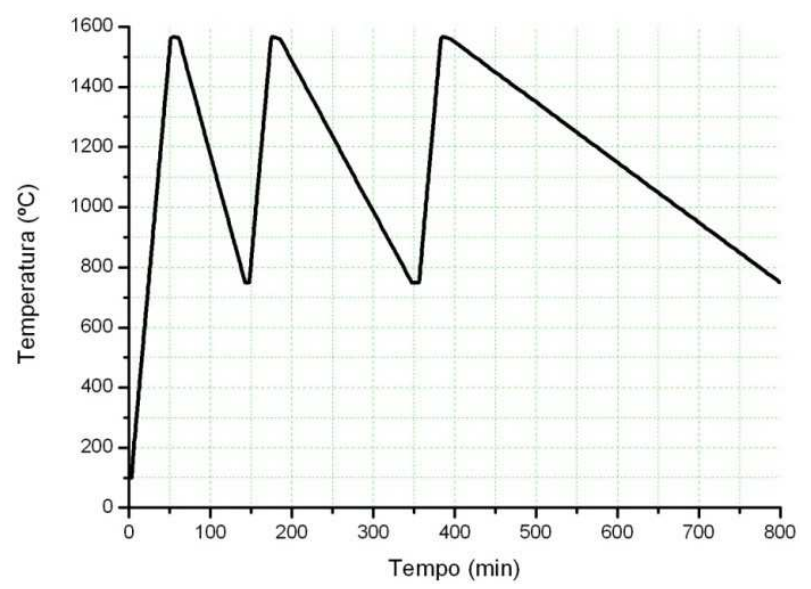

Figura 5.22: Ciclo térmico do ensaio de DTA do aço AISI 430 na condição BQB.

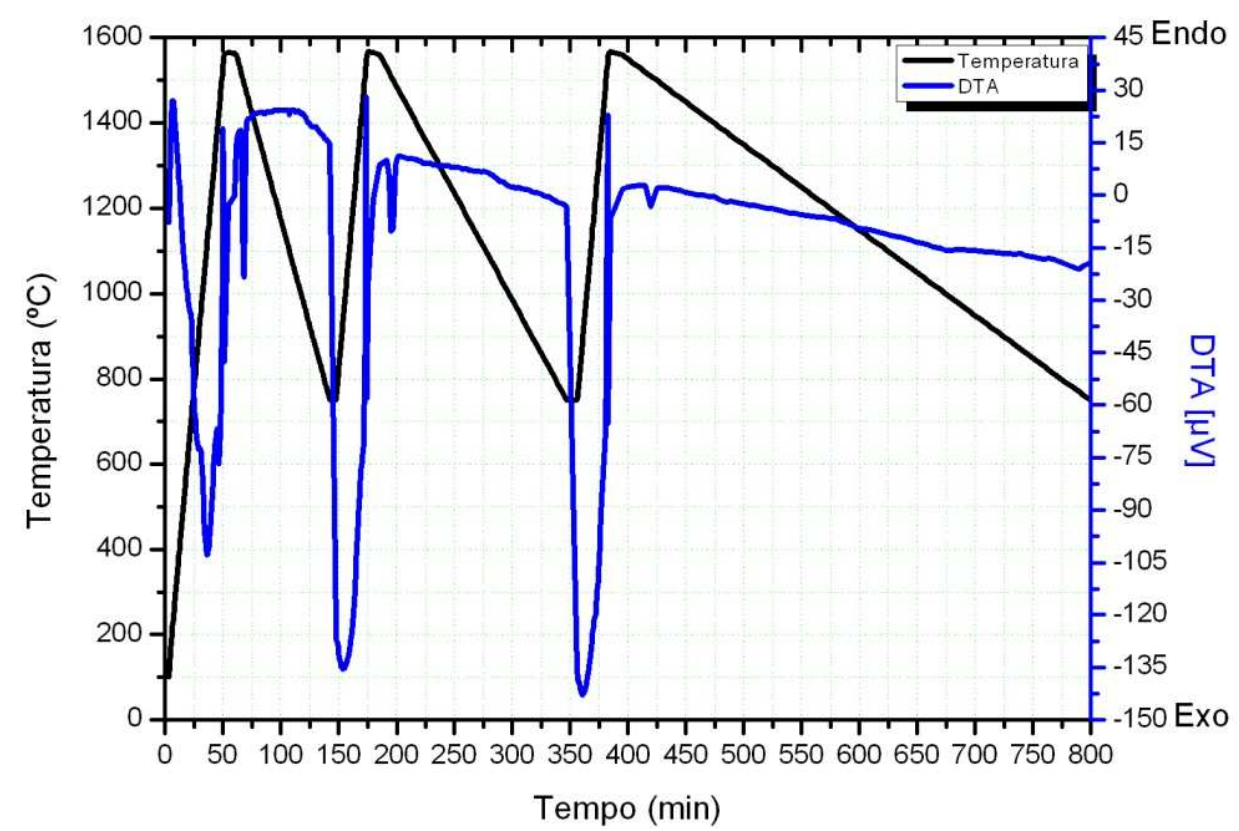

Figura 5.23: Resultado do ensaio de DTA para a amostra do aço AISI 430 na condição $B Q$ Recozido. Diferença de potencial em relação à alumina $(\mathrm{DTA}[\mu \mathrm{V}])$ e temperatura $\left[{ }^{\circ} \mathrm{C}\right]$ em função do tempo do ensaio [min].

De modo a se verificar as taxas de aquecimento utilizadas no ensaio de DTA, foi calculado com auxílio do programa Origin 8.0, a curva derivada da temperatura em função do tempo, a qual é apresentada na figura 5.24. Verifica-se que a estabilidade das taxas de aquecimento/resfriamento aumenta com a diminuição do módulo destas, e que as taxas empregadas na programação do ciclo térmico no DTA podem ser consideradas como constantes no ciclo térmico utilizado. 


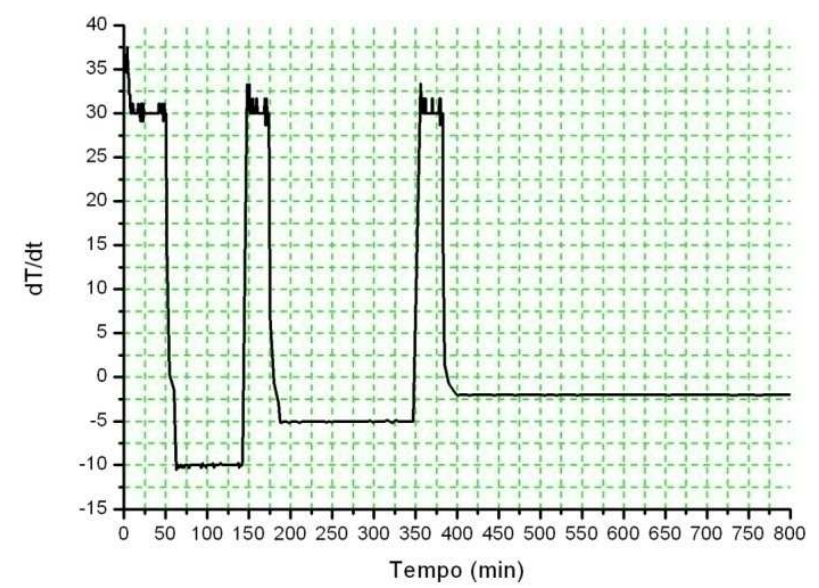

Figura 5.24: Taxas de aquecimento/resfriamento em função do tempo de ensaio de DTA para o aço AISI 430 na condição BQ Recozido.

Como meio de avaliar com maior facilidade as inflexões da curva de DTA, foi calculada com auxílio do programa Origin 8.0 a derivada da curva DTA em função do tempo, apresentada na figura 5.25.

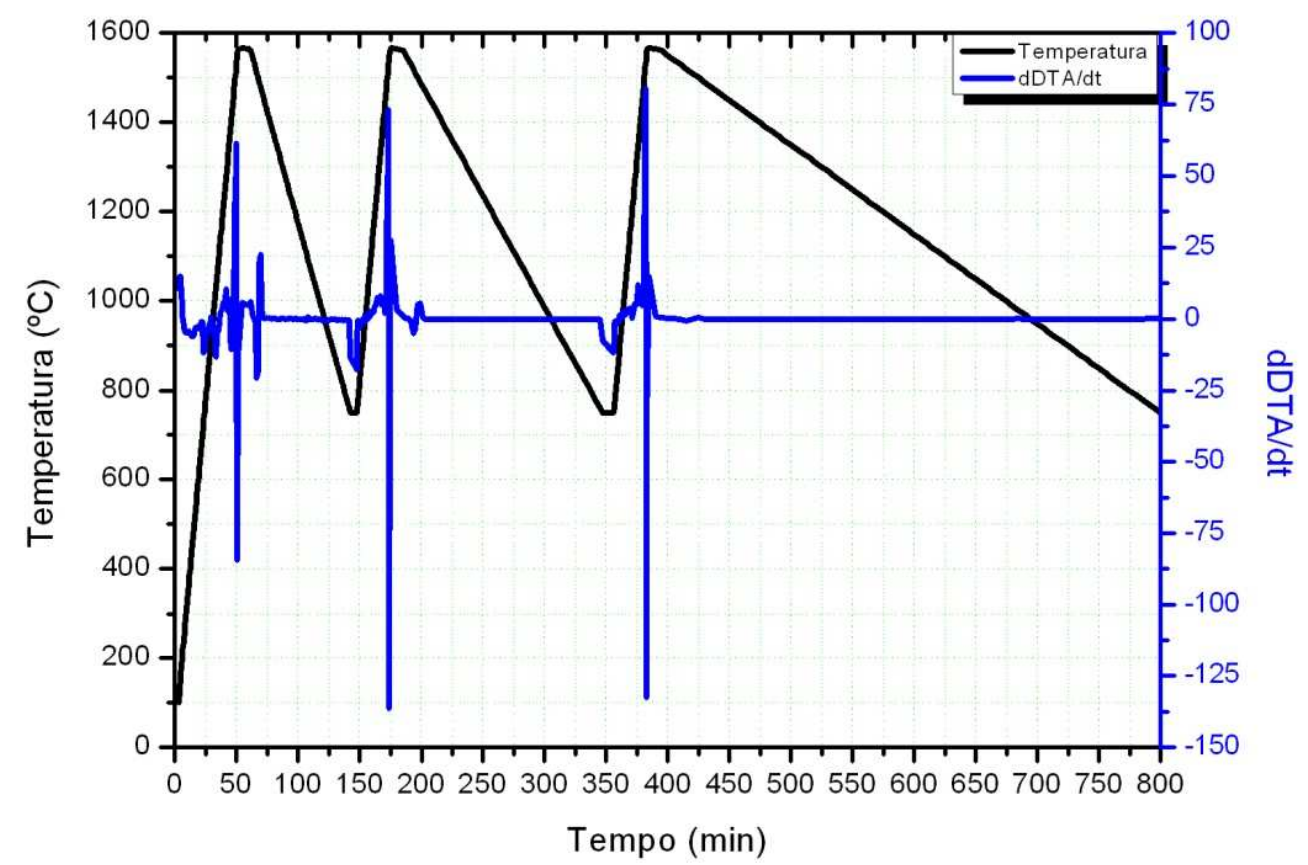

Figura 5.25: Derivada da curva DTA em função da temperatura para o aço AISI 430 na condição BQ Recozido.

Verifica-se do Cálculo que os zeros da primeira derivada de uma função indicam os pontos de máximo e de mínimo destas. Assim, os pontos da curva derivada do DTA com respeito ao tempo que cortam o eixo do tempo indicam os pontos de máximo/mínimo da curva do DTA.

Dividindo-se o gráfico da figura 5.25 por ciclo térmico, pode-se avaliar com maior detalhe as inflexões da curva derivada do DTA com relação ao tempo. $\mathrm{Na}$ figura 5.26 são apresentados os gráficos do DTA em função da temperatura e das 
curvas derivadas para taxa de resfriamento de $10^{\circ} \mathrm{C} / \mathrm{min}$.

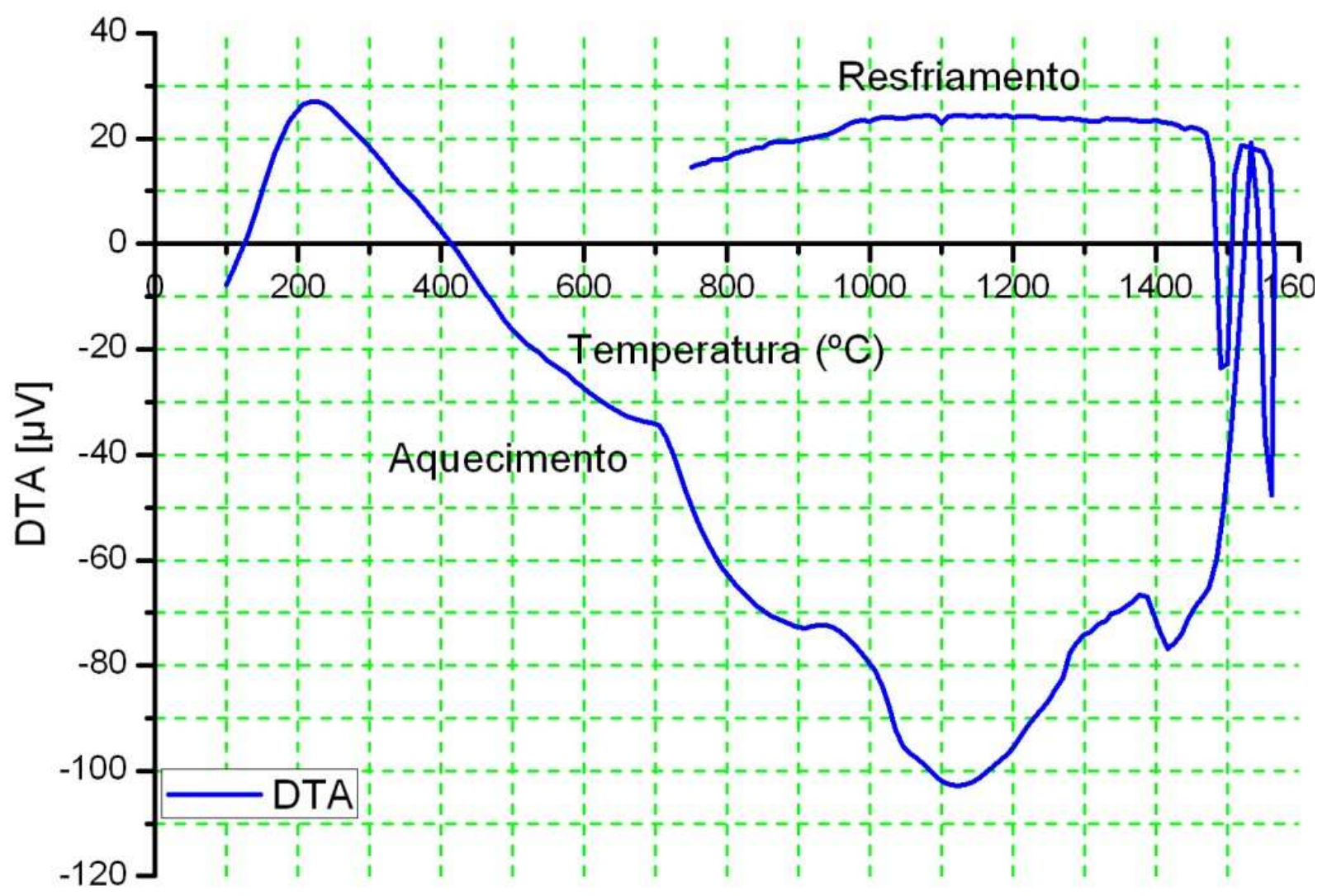

(a)

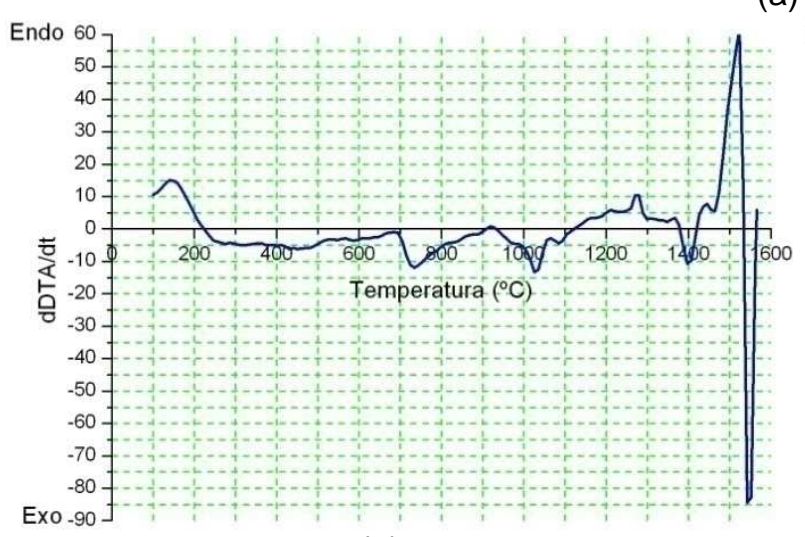

(b)

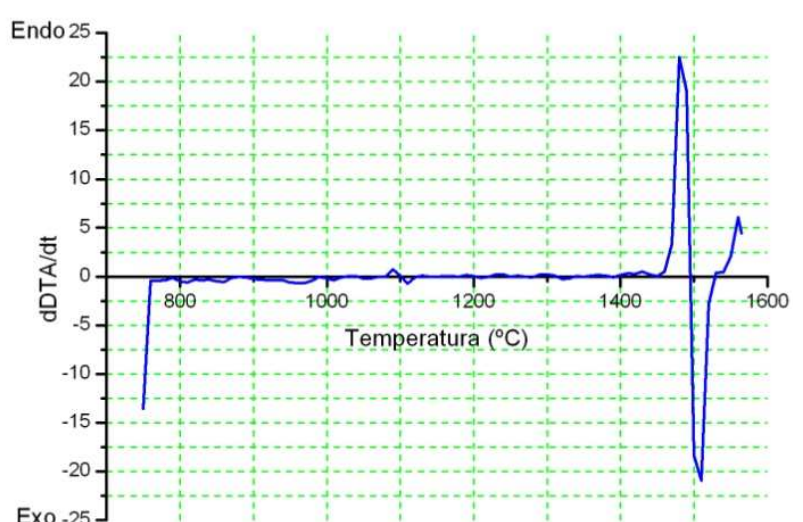

(c)

Figura 5.26: (a) Curva do DTA em função da temperatura para o aço AISI 430 na condição BQ Recozido para o ciclo térmico com taxa de resfriamento de $10^{\circ} \mathrm{C} / \mathrm{min}$. (b) Derivada da curva DTA em função da temperatura para o aquecimento do ciclo térmico. (c) Derivada da curva DTA em função da temperatura para o resfriamento do ciclo térmico.

$\mathrm{Na}$ figura 5.27 são apresentados os gráficos do DTA em função da temperatura e das curvas derivadas para taxa de resfriamento de $5^{\circ} \mathrm{C} / \mathrm{min}$. 


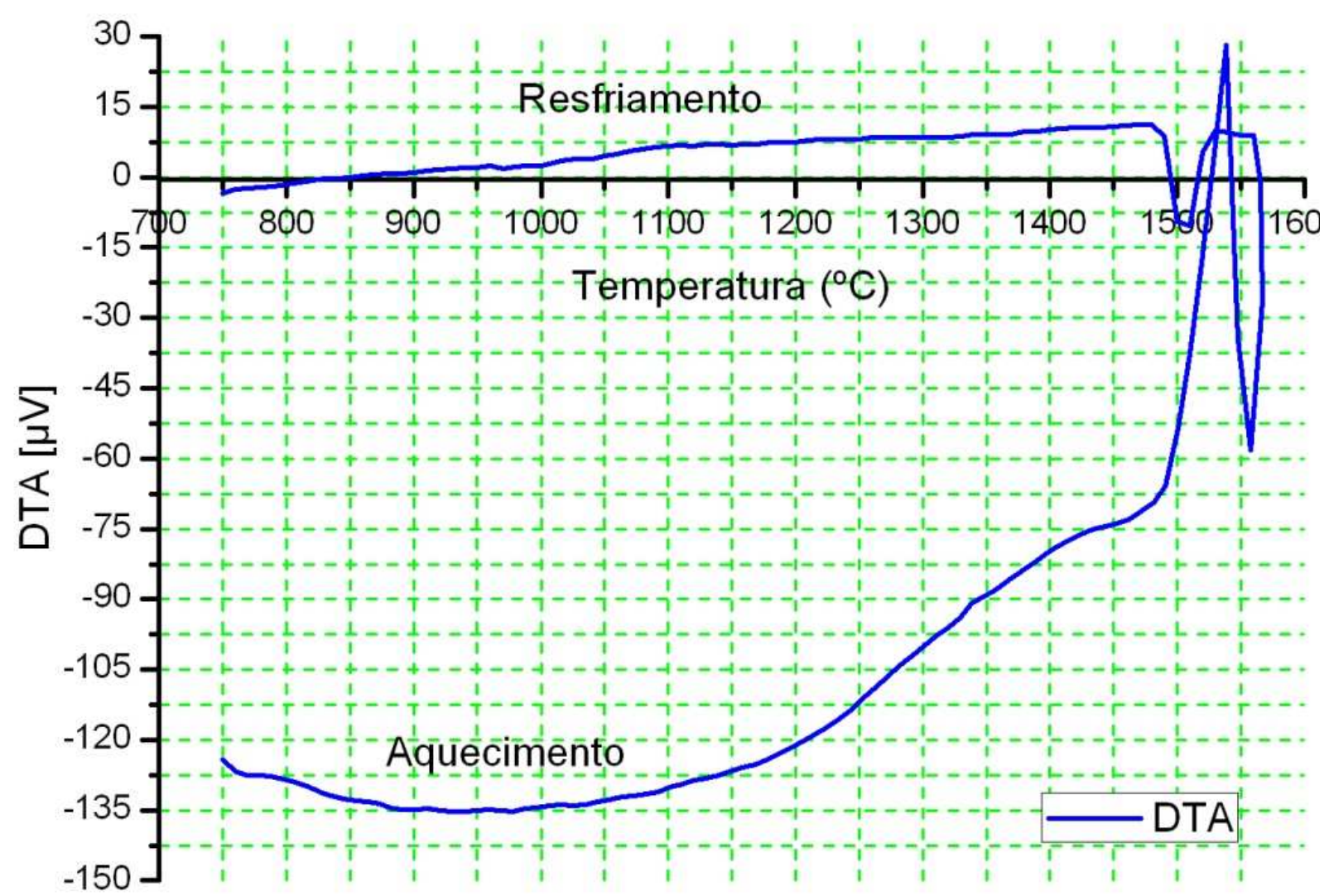

(a)

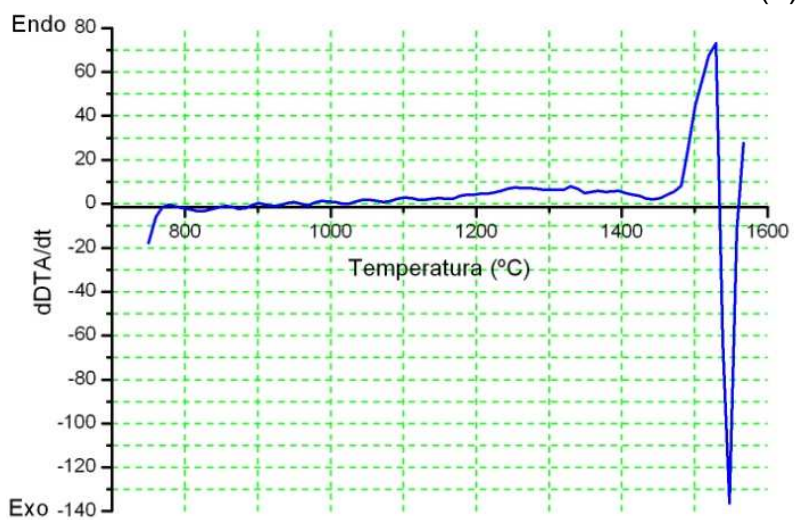

(b)

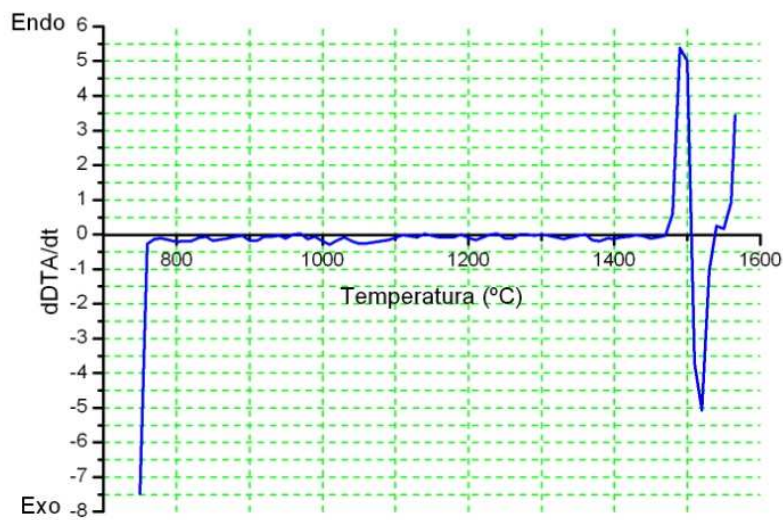

(c)

Figura 5.27: (a) Curva do DTA em função da temperatura para o aço AISI 430 na condição BQ Recozido para o ciclo térmico com taxa de resfriamento de $5{ }^{\circ} \mathrm{C} / \mathrm{min}$. (b) Derivada da curva DTA em função da temperatura para o aquecimento do ciclo térmico. (c) Derivada da curva DTA em função da temperatura para o resfriamento do ciclo térmico.

$\mathrm{Na}$ figura 5.28 são apresentados os gráficos do DTA em função da temperatura e das curvas derivadas para taxa de resfriamento de $2^{\circ} \mathrm{C} / \mathrm{min}$. 


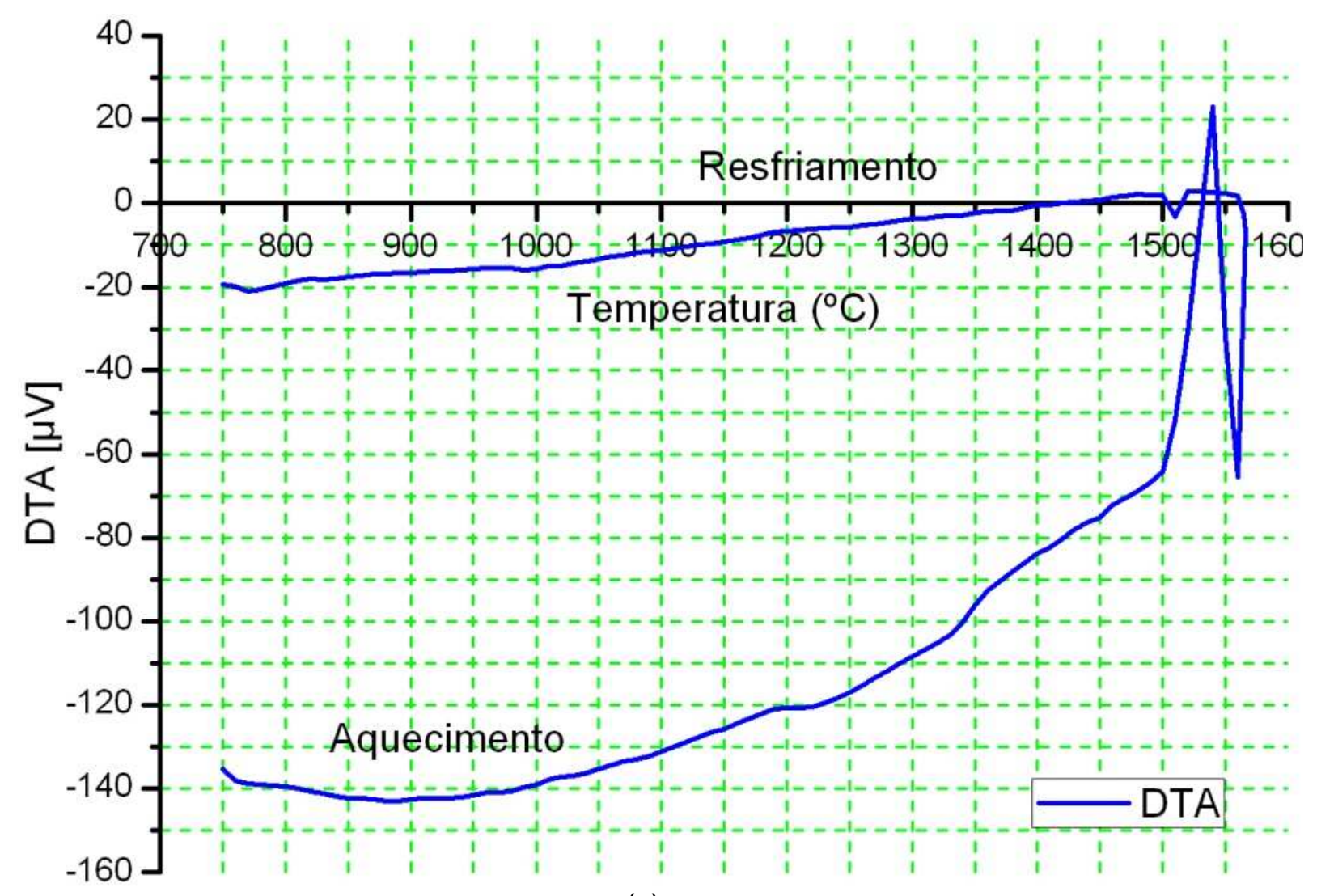

(a)

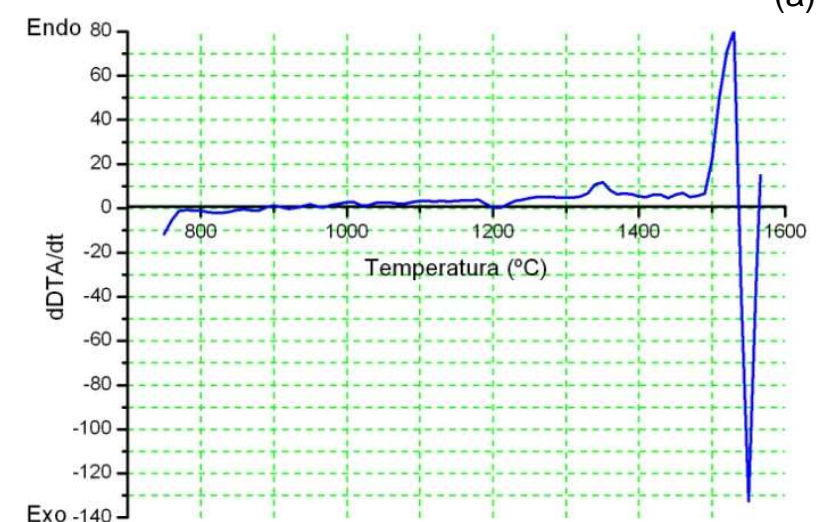

(b)

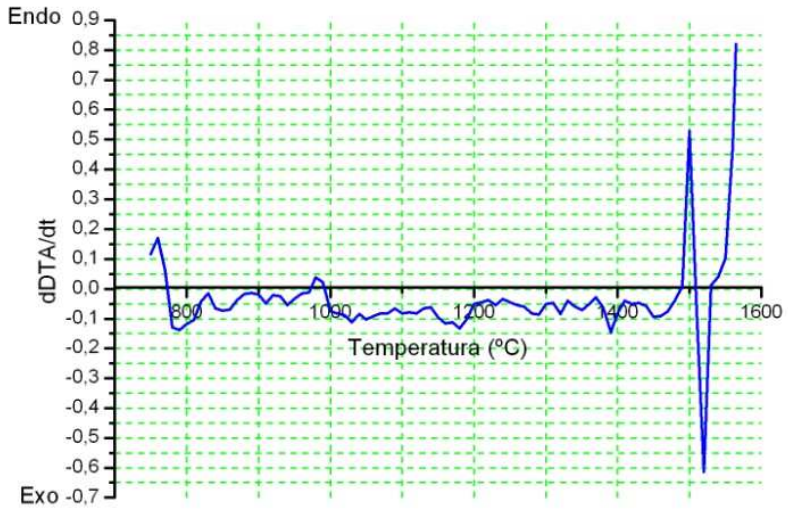

(c)

Figura 5.28: (a) Curva do DTA em função da temperatura para o aço AISI 430 na condição $B Q$ Recozido para o ciclo térmico com taxa de resfriamento de ${ }^{2} \mathrm{C} / \mathrm{min}$. (b) Derivada da curva DTA em função da temperatura para o aquecimento do ciclo térmico. (c) Derivada da curva DTA em função da temperatura para o resfriamento do ciclo térmico.

Dos gráficos das figuras 5.26, 5.27 e 5.28 podem ser extraídas as inflexões das curvas referentes às transformações de fases ao longo dos ciclos de aquecimento e de resfriamento da amostra. Na tabela 5.11 são apresentados todos os pontos de inflexão com as respectivas médias por ciclos onde se observa que muitos pontos de inflexão não foram verificados em todos os ciclos térmicos bem como alguns pontos foram verificados somente no aquecimento dos ciclos. 
Tabela 5.11: Inflexões da curva do DTA em função da temperatura para os ciclos térmicos do ensaio de DTA do aço AISI 430 na condição BQB.

\begin{tabular}{|c|c|c|c|c|c|}
\hline \multicolumn{2}{|c|}{$1^{\circ}$ Ciclo Térmico } & \multicolumn{2}{|c|}{$2^{\circ}$ Ciclo Térmico } & \multicolumn{2}{|c|}{$3^{\circ}$ Ciclo Térmico } \\
\hline Aquecimento & Resfriamento & Aquecimento & Resfriamento & Aquecimento & \begin{tabular}{|l|} 
Resfriamento \\
\end{tabular} \\
\hline $30^{\circ} \mathrm{C} / \mathrm{min}$ & $10^{\circ} \mathrm{C} / \mathrm{min}$ & $30^{\circ} \mathrm{C} / \mathrm{min}$ & $5^{\circ} \mathrm{C} / \mathrm{min}$ & $30^{\circ} \mathrm{C} / \mathrm{min}$ & $2^{\circ} \mathrm{C} / \mathrm{min}$ \\
\hline Inflexões & Inflexões & Inflexões & Inflexões & Inflexões & Inflexões \\
\hline 1563 & 1530 & 1557 & 1525 & 1560 & 1520 \\
\hline 1475 & 1470 & 1492 & 1471 & 1500 & 1497 \\
\hline 1420 & 1393 & 1434 & 1360 & 1450 & 1400 \\
\hline 1379 & 1313 & 1341 & 1323 & 1409 & 1200 \\
\hline 1300 & 1200 & 1236 & 1215 & 1334 & 1023 \\
\hline 1280 & 1101 & 1177 & 1113 & 1220 & 993 \\
\hline 1271 & 990 & 1081 & 1030 & 1193 & 957 \\
\hline 1123 & 883 & 1025 & 1000 & 1077 & 823 \\
\hline 1036 & 790 & 973 & 965 & 1016 & 773 \\
\hline 1016 & --- & 881 & 843 & 925 & --- \\
\hline 933 & --- & 849 & --- & 886 & --- \\
\hline 908 & --- & 763 & --- & 764 & --- \\
\hline 841 & --- & --- & --- & --- & --- \\
\hline 705 & --- & --- & --- & --- & --- \\
\hline 223 & --- & --- & --- & --- & --- \\
\hline
\end{tabular}

Utilizando os dados da tabela 5.11, na forma bruta, isto é todos os pontos de inflexão da curva do DTA, em adição às temperaturas das transformações de fases em equilíbrio calculadas como programa ThermoCalc (tabela 5.2), foi obtido o gráfico da figura 5.29. Como o estado de equilíbrio supõe tempo infinito para a estabilização do mesmo, as temperaturas das transformações de fases têm por conseqüência taxa de aquecimento/resfriamento nulas. Observa-se também que foram colocadas barras de erros nas temperaturas das inflexões com desvio padrão de $5^{\circ} \mathrm{C}$, em acordo com a literatura ${ }^{(61)}$. 


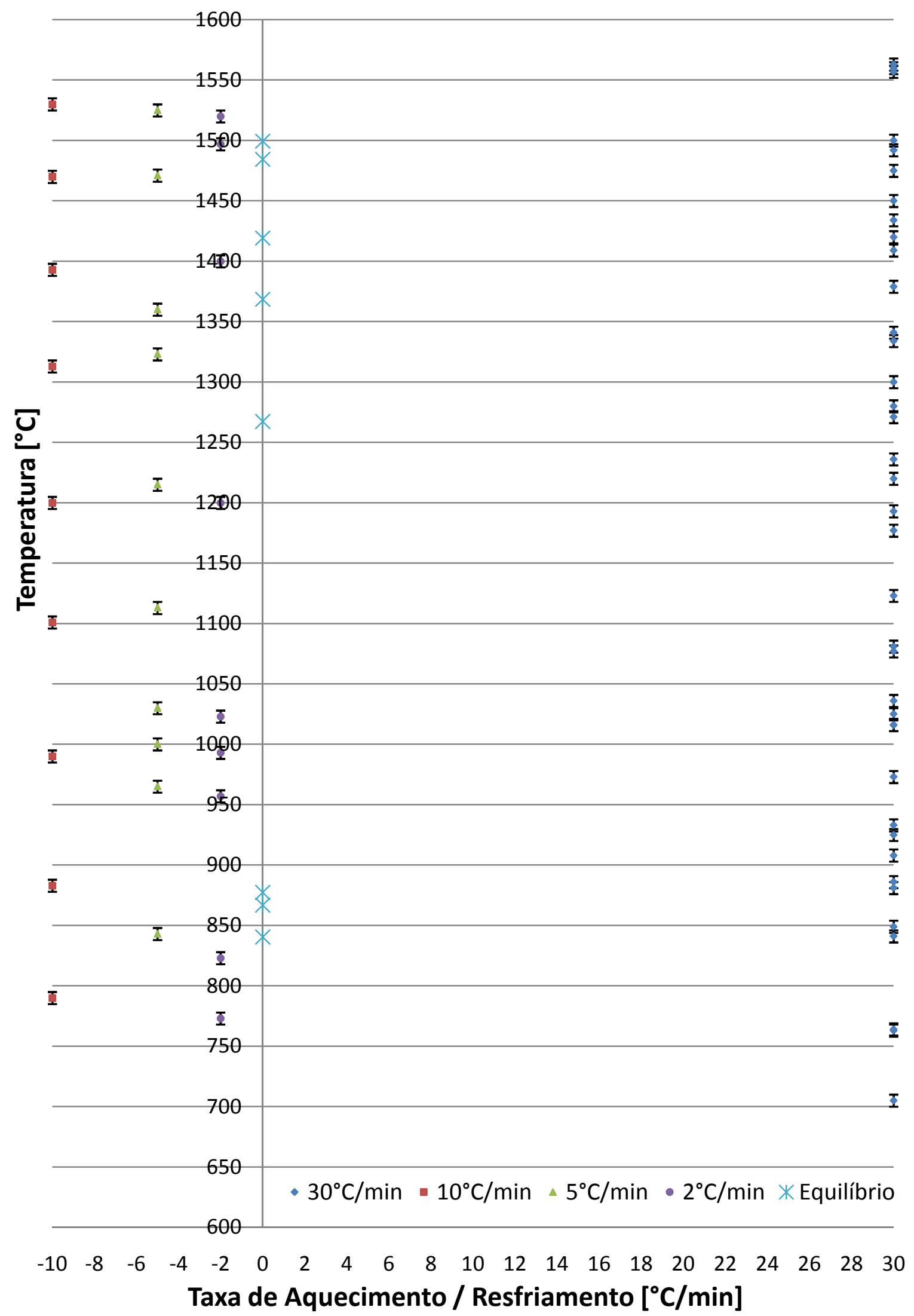

Figura 5.29: Temperaturas das inflexões da curva do DTA em função da taxa de aquecimento/resfriamento em comparação com os dados de equilíbrio calculados com o programa ThermoCalc. 


\subsection{Discussão}

$\mathrm{Na}$ figura 6.1 apresentam-se micrografias em MO e MEV com ataque por reagente Villela das amostras do aço AISI 430 nas condições industriais (BQP, BQB e BFB).

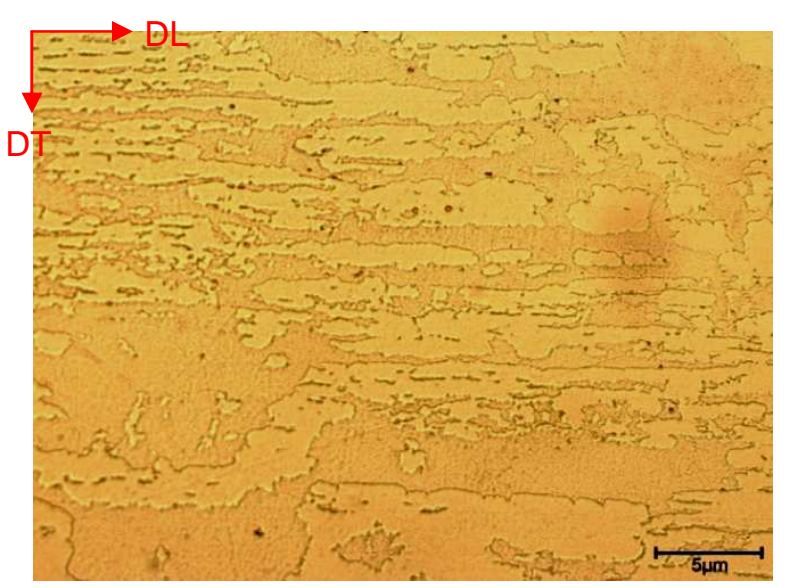

(a)

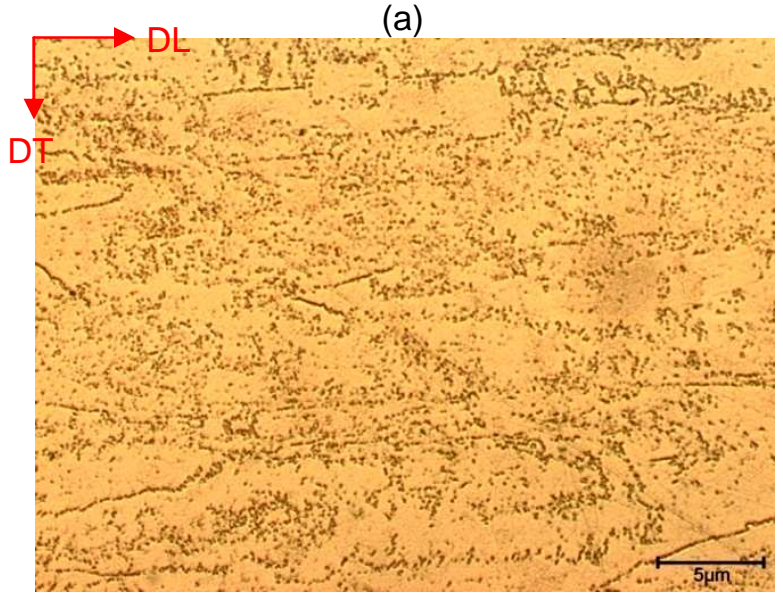

(c)

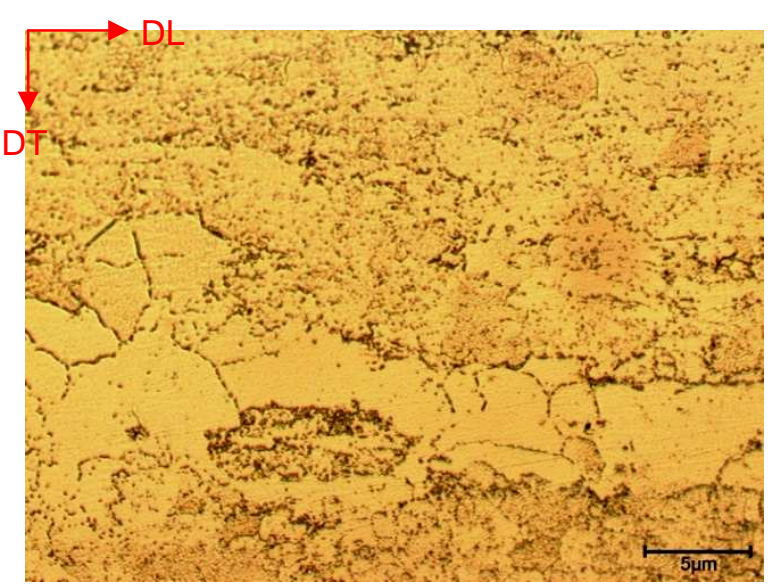

(b)

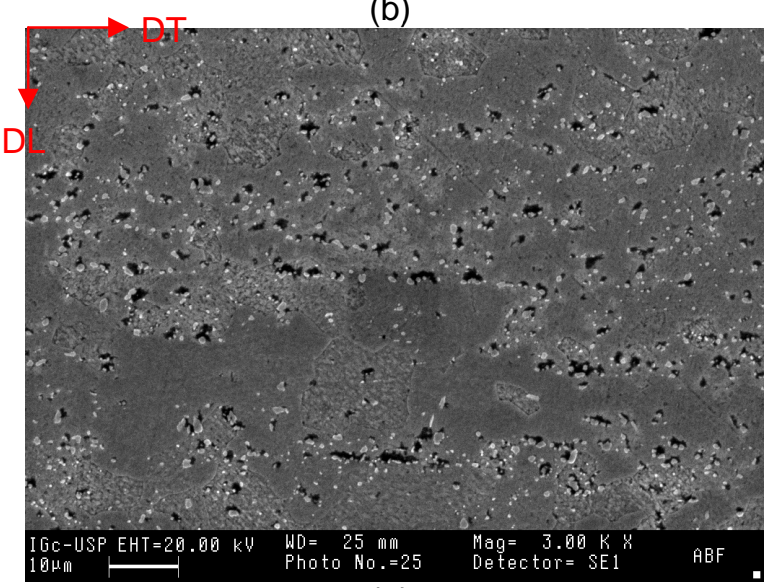

(d)

Figura 6.1: Micrografias do aço AISI 430 nas três condições industriais como recebidas com ataque por reagente Villela. Microscopia ótica (a) BQP, (b) BQB e (c) BFB. Microscopia eletrônica de varredura (d) BFB.

A condição BQP é o aço AISI 430 após laminação a quente, com a última cadeira de laminação na temperatura de $900^{\circ} \mathrm{C}$, resfriado até $600^{\circ} \mathrm{C}$ e bobinado sendo posteriormente resfriado ao ar até a temperatura ambiente. Observa-se da micrografia da figura 6.1(a) que os grãos estão com forma achatada e alongada (panqueca). A condição BQB refere-se ao aço AISI 430 na condição BQP que foi recozido a $8^{\circ} 0^{\circ} \mathrm{C}$ e posteriormente a camada oxidada da superfície foi removida com decapagem química ácida. O aço AISI 430 na condição BFB refere-se ao aço AISI 430 na condição $B Q B$ que foi laminado a frio, recozido por $28 \mathrm{~s}$ a $830^{\circ} \mathrm{C}$ e a camada oxidada da superfície foi removida com decapagem química ácida.

Nas micrografias (a) e (b) da figura 6.1 observa-se que durante o recozimento 
do aço BQP, para a condição $B Q B$, houve recristalização e precipitação de carbonetos nos contornos de grão e alguns carbonetos intra-granulares. Ao se laminar e recozer o aço AISI 430 da condição BQB para a condição BFB foi observado um refinamento da microestrutura e um aumento na fração volumétrica e na dispersão dos carbonetos na microestrutura.

Os resultados da caracterização microestrutural das três condições industriais analisadas do aço AISI 430 mostraram-se coerentes com os resultados da difração de raios-X da matriz e dos precipitados extraídos apresentados na tabela 6.1.

Tabela 6.1: Resultados da difração de raios-X. As porcentagens de $(\mathrm{Cr}, \mathrm{Fe})_{2} \mathrm{~N}$ e de $(\mathrm{Cr}, \mathrm{Fe})_{23} \mathrm{C}_{6}$ foram calculadas a partir da tabela 5.10, excluindo-se os produtos de extração. Os parâmetros de rede a e c são apresentados em Á.

\begin{tabular}{|c|c|c|c|c|c|c|c|c|c|}
\hline \multirow{3}{*}{ Amostra } & \multicolumn{3}{|c|}{ Difratogramas dos precipitados extraídos } & \multicolumn{4}{c|}{ Difratogramas da matriz } \\
\cline { 2 - 10 } & \multicolumn{3}{|c|}{$(\mathrm{Cr}, \mathrm{Fe})_{2} \mathrm{~N}$} & \multicolumn{2}{|c|}{$(\mathrm{Cr}, \mathrm{Fe})_{23} \mathrm{C}_{6}$} & \multicolumn{2}{c|}{ Ferrita baixo cromo } & \multicolumn{2}{c|}{ Ferrita alto cromo } \\
\cline { 2 - 10 } & $\%$ at. & $\mathrm{a}[\hat{\mathrm{A}}]$ & $\mathrm{c}[\hat{\mathrm{A}}]$ & $\%$ at. & $\mathrm{a}[\hat{\mathrm{A}}]$ & $\%$ at. & $\mathrm{a}[\hat{\mathrm{A}}]$ & $\%$ at. & $\mathrm{a}[\hat{\mathrm{A}}]$ \\
\hline $\mathrm{BQP}$ & 100.0 & 4.851 & 4.167 & 0.0 & - & 26.6 & 2.872 & 73.4 & 2.875 \\
\hline $\mathrm{BQB}$ & 44.9 & 4.809 & 4.458 & 55.1 & 10.606 & 34.1 & 2.871 & 65.9 & 2.874 \\
\hline $\mathrm{BFB}$ & 69.5 & 4.821 & 4.452 & 30.5 & 10.589 & 100.0 & 2.872 & & \\
\hline
\end{tabular}

Da tabela 6.1 pode-se observar que:

$>$ Condição BQP: Presença de duas fases ferrita com dispersão de nitreto do tipo $(\mathrm{Cr}, \mathrm{Fe})_{2} \mathrm{~N}$.

> Condição BQB: Presença de duas fases ferrita com dispersão de nitreto do tipo $(\mathrm{Cr}, \mathrm{Fe})_{2} \mathrm{~N}$ e de carboneto do tipo $(\mathrm{Cr}, \mathrm{Fe})_{23} \mathrm{C}_{6}$.

$>$ Condição BFB: Matriz ferrítica com dispersão de nitreto do tipo $(\mathrm{Cr}, \mathrm{Fe})_{2} \mathrm{~N}$ e de carboneto do tipo $(\mathrm{Cr}, \mathrm{Fe})_{23} \mathrm{C}_{6}$.

As condições tratadas termicamente deste trabalho partiram da condição BQB visto que esta condição apresentaria menor influência dos processos de recristalização/recuperação do aço AISI 430. Foram realizados seis tratamentos térmicos nas temperaturas de $600^{\circ} \mathrm{C}, 700^{\circ} \mathrm{C}, 8^{\circ} 0^{\circ} \mathrm{C}, 90^{\circ} \mathrm{C}, 10000^{\circ} \mathrm{C}$ e $11000^{\circ} \mathrm{C}$, todos por 5 h sob vácuo. Na figura 6.2 apresentam-se micrografias em MO das amostras tratadas. 


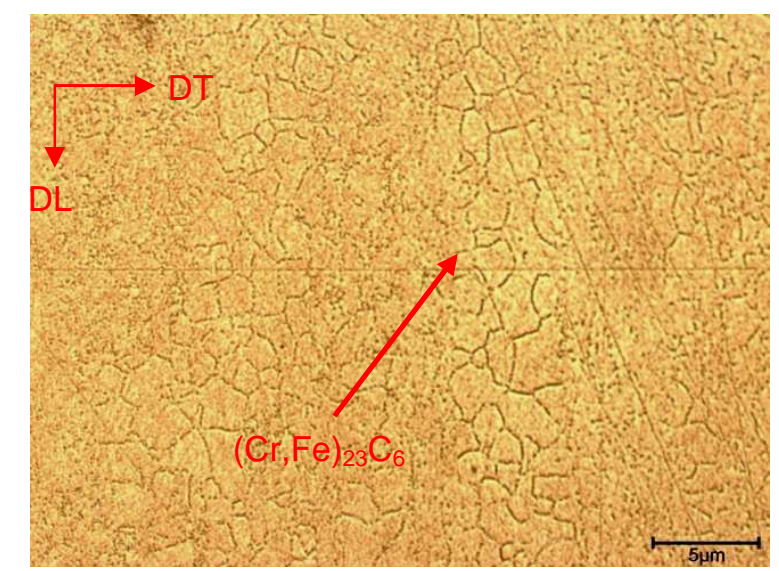

(a)

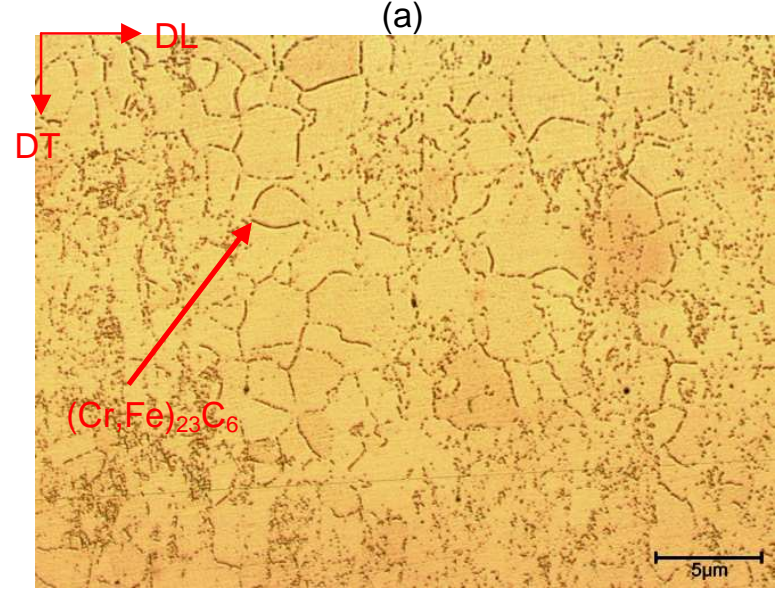

(c)

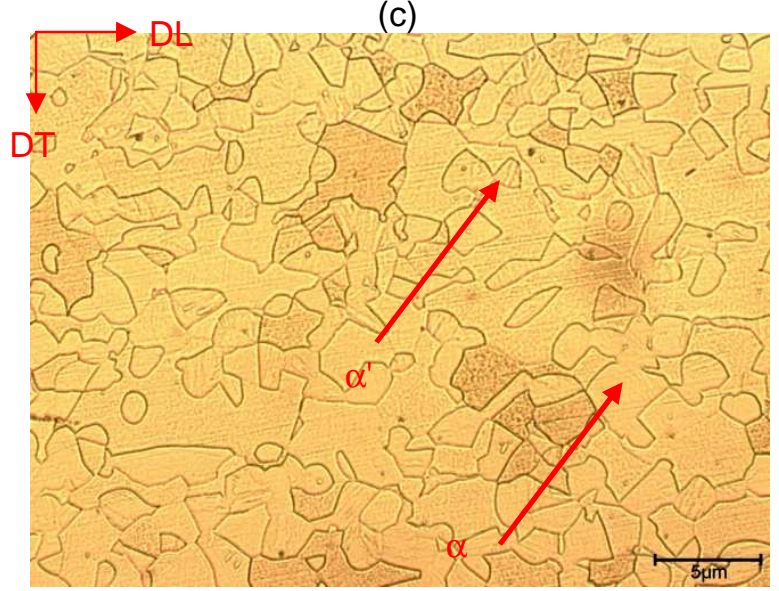

(e)

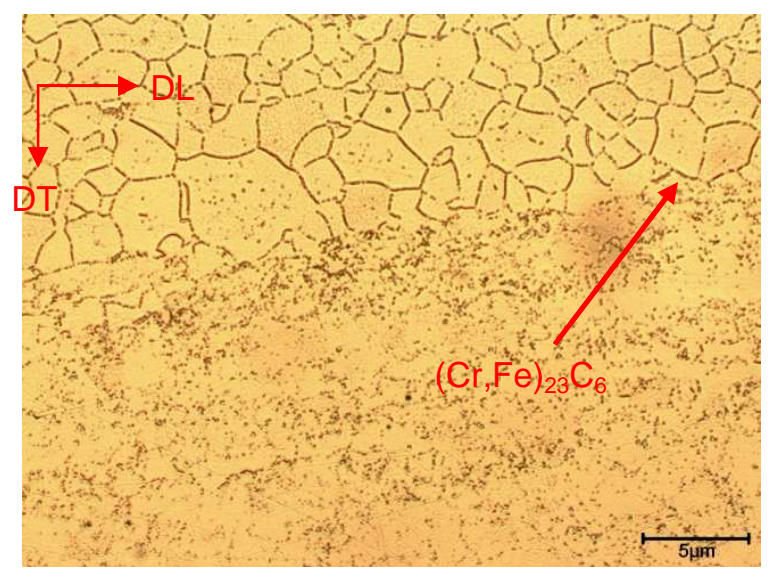

(b)

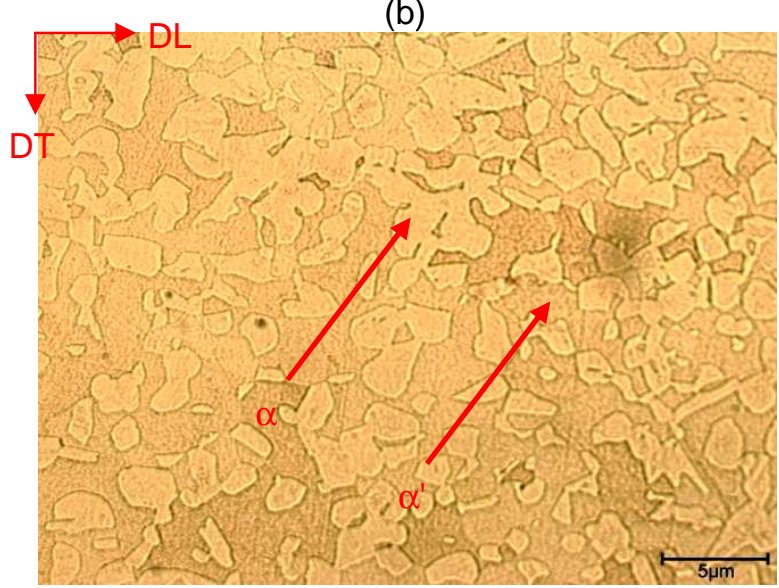

(d)

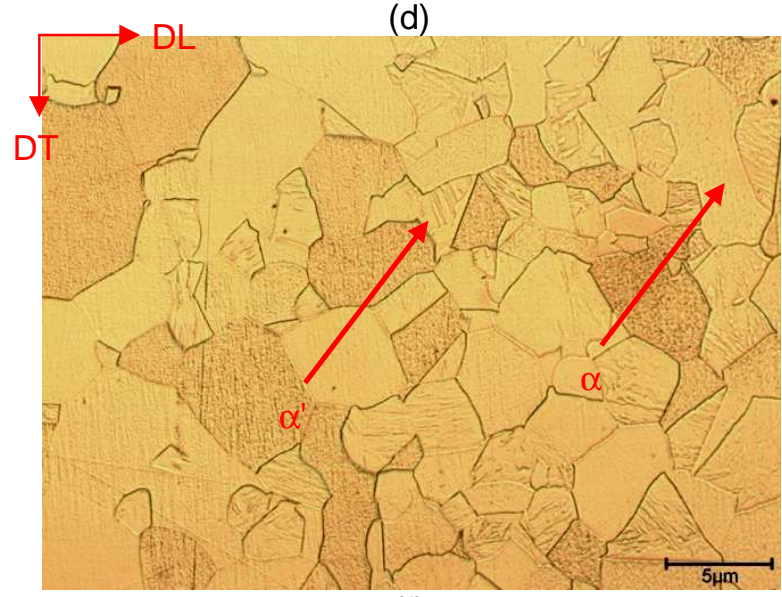

(f)

Figura 6.2: Micrografias em MO com ataque por reagente Villela das amostras tratadas termicamente do aço AISI 430 a (a) $600^{\circ} \mathrm{C} / 5 \mathrm{~h}$, (b) $7000^{\circ} \mathrm{C} / 5 \mathrm{~h}$, (c) $800^{\circ} \mathrm{C} / 5 \mathrm{~h}$, (d) $900^{\circ} \mathrm{C} / 5 \mathrm{~h}$, (e) $1000^{\circ} \mathrm{C} / 5 \mathrm{~h}$ e (f) $1100^{\circ} \mathrm{C} / 5 \mathrm{~h}$.

As amostras tratadas a $600^{\circ} \mathrm{C}$ e $700^{\circ} \mathrm{C}$ apresentaram $\mathrm{m}$ icroestruturas extremamente similares a condição inicial do tratamento térmico (BQB). Observouse na amostra tratada a $700{ }^{\circ} \mathrm{C}$ o início da recristal ização da matriz, com uma pequena redução da fração volumétrica dos precipitados. Na amostra tratada a $800^{\circ} \mathrm{C}$ observa-se um maior crescimento de grão em relação à amostra tratada a $700{ }^{\circ}$, aliado com uma maior taxa de recristalização dos grãos. A amostra tratada a $900{ }^{\circ} \mathrm{C}$ apresentou pouquíssimos precipitados e uma matriz dúplex. As amostras tratadas a $1000{ }^{\circ} \mathrm{C}$ e $1100^{\circ} \mathrm{C}$ apresentar am matriz dúplex com presença da fase 
martensita após a têmpera. A presença da fase martensita após a têmpera indica que em alta temperatura esta amostra estava no campo bifásico austenita/ferrita. As amostras tratadas a $1000^{\circ} \mathrm{C}$ e $1100^{\circ} \mathrm{C}$ não apresentara $\mathrm{m}$ a presença de precipitados visíveis por $\mathrm{MO}$.

Tabela 6.2: Resultados da difração de raios-X. As porcentagens de $(\mathrm{Cr}, \mathrm{Fe})_{2} \mathrm{~N}$ e de $(\mathrm{Cr}, \mathrm{Fe})_{23} \mathrm{C}_{6}$ foram calculadas a partir da tabela 5.10, excluindo-se os produtos de extração. Os parâmetros de rede a e c são apresentados em Á.

\begin{tabular}{|c|c|c|c|c|c|c|c|c|c|}
\hline \multirow{3}{*}{ Amostra } & \multicolumn{5}{|c|}{ Difratogramas dos precipitados extraídos } & \multicolumn{4}{|c|}{ Difratogramas da matriz } \\
\hline & \multicolumn{3}{|c|}{$(\mathrm{Cr}, \mathrm{Fe})_{2} \mathrm{~N}$} & \multicolumn{2}{|c|}{$(\mathrm{Cr}, \mathrm{Fe})_{23} \mathrm{C}_{6}$} & \multicolumn{2}{|c|}{ Ferrita baixo cromo } & \multicolumn{2}{|c|}{ Ferrita alto cromo } \\
\hline & $\%$ at. & $\mathrm{a}[\hat{A}]$ & $c[\hat{A}]$ & $\%$ & $\mathrm{a}[\hat{A}]$ & $\%$ & $\mathrm{a}[\hat{A}]$ & $\%$ & $\mathrm{a}[\AA \overline{]}]$ \\
\hline $600^{\circ} \mathrm{C} / 5 \mathrm{~h}$ & 62.3 & 4.797 & 4.457 & 37.7 & 10.587 & 100.0 & 2.873 & & \\
\hline $700^{\circ} \mathrm{C} / 5 \mathrm{~h}$ & 70.4 & 4.790 & 4.497 & 29.6 & 10.595 & 100.0 & 2.873 & & \\
\hline $800^{\circ} \mathrm{C} / 5 \mathrm{~h}$ & 83.4 & 4.827 & 4.461 & 16.6 & 10.605 & 100.0 & 2.873 & & \\
\hline $900^{\circ} \mathrm{C} / 5 \mathrm{~h}$ & 77.8 & 5.105 & 4.572 & 22.2 & 10.618 & 66.0 & 2.873 & 34.0 & 2.884 \\
\hline $1000^{\circ} \mathrm{C} / 5 \mathrm{~h}$ & 0.00 & - & - & 100.0 & 10.692 & 66.3 & 2.873 & 33.4 & 2.883 \\
\hline $1100^{\circ} \mathrm{C} / 5 \mathrm{~h}$ & 0.00 & - & - & 0.0 & - & 67.8 & 2.873 & 32.2 & 2.884 \\
\hline
\end{tabular}

Em acordo com a caracterização metalográfica, verifica-se da tabela 6.2 que o aço AISI 430 apresenta matriz praticamente $100 \%$ ferrítica até $800{ }^{\circ} \mathrm{C}$. Verificou-se que após os tratamentos térmicos por $5 \mathrm{~h}$ a $900^{\circ} \mathrm{C}, 1000^{\circ} \mathrm{C}$ e a $1100^{\circ} \mathrm{C}$ seguido de têmpera, o aço AISI 430 apresentou estrutura bifásica ferrita/martensita com frações volumétricas de martensita crescentes como aumento da temperatura do tratamento térmico, entretanto, as frações das fases ferrita (alto e baixo cromo) identificadas pela análise de Rietveld mostraram-se constantes para as três temperaturas. Estes resultados indicam que o campo bifásico austenita/ferrita deve iniciar entre $800^{\circ} \mathrm{C}$ e $900^{\circ} \mathrm{C}$.

$\mathrm{Na}$ caracterização por $\mathrm{MO}$ foi observada a presença de carbonetos do tipo $\mathrm{M}_{23} \mathrm{C}_{6}$ identificados na DR-X dos precipitados extraídos nas amostras tratadas a $600^{\circ} \mathrm{C} / 5 \mathrm{~h}, 700^{\circ} \mathrm{C} / 5 \mathrm{~h}$ e $800^{\circ} \mathrm{C} / 5 \mathrm{~h}$. Na figura 6.3 aprese ntam-se micrografias em MO, com maior aumento, com ataque por reagente Villela do aço AISI 430 tratado a $700^{\circ} \mathrm{C} / 5 \mathrm{~h}$ e $800^{\circ} \mathrm{C} / 5 \mathrm{~h}$ mostrando-se a distribuição dos carbonetos na matriz. Destas micrografias, observa-se que os carbonetos do tipo $\mathrm{M}_{23} \mathrm{C}_{6}$ apresentaram-se preferencialmente nos contornos de grão, no entanto, foi observada a presença de carbonetos intragranulares. 


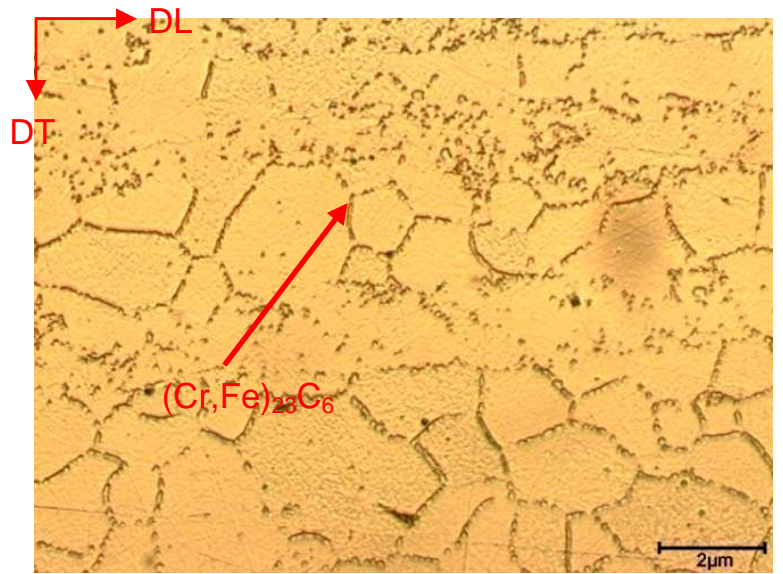

(a)

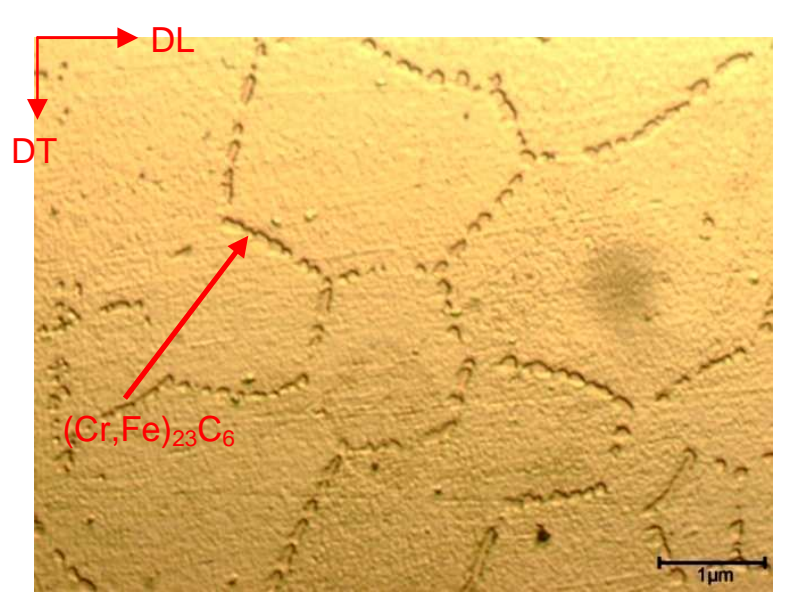

(b)

Figura 6.3: Micrografias em $\mathrm{MO}$ com ataque por reagente Villela das amostras tratadas termicamente do aço AISI 430 a (a) $700^{\circ} \mathrm{C} / 5 \mathrm{~h}$ e (b) $80^{\circ} \mathrm{C} / 5 \mathrm{~h}$.

A presença dos nitretos do tipo $(\mathrm{Cr}, \mathrm{Fe})_{2} \mathrm{~N}$ observados na DR-X dos precipitados extraídos não foi verificada por MO. A verificação da presença destes carbonitretos somente foi possível através de MEV com EDS. Na figura 6.4 apresentam-se micrografias em MEV das amostras tratadas a $700^{\circ} \mathrm{C} / 5 \mathrm{~h}$ e BFB.

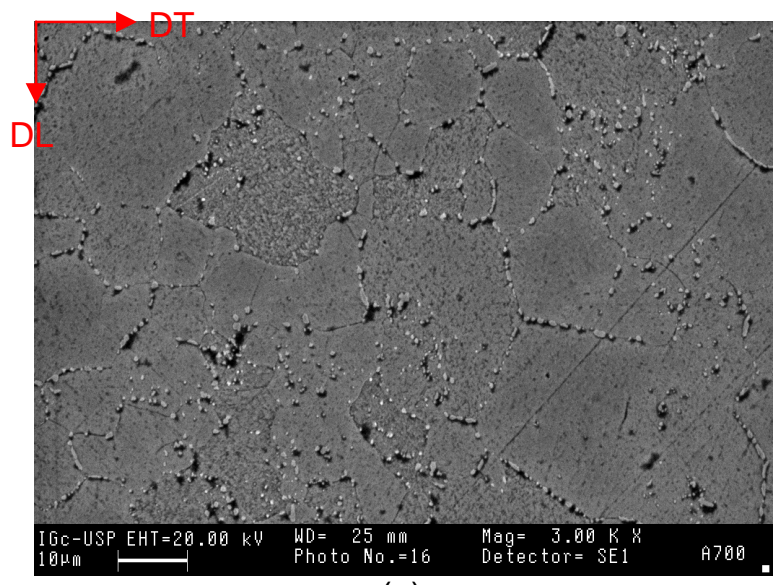

(a)

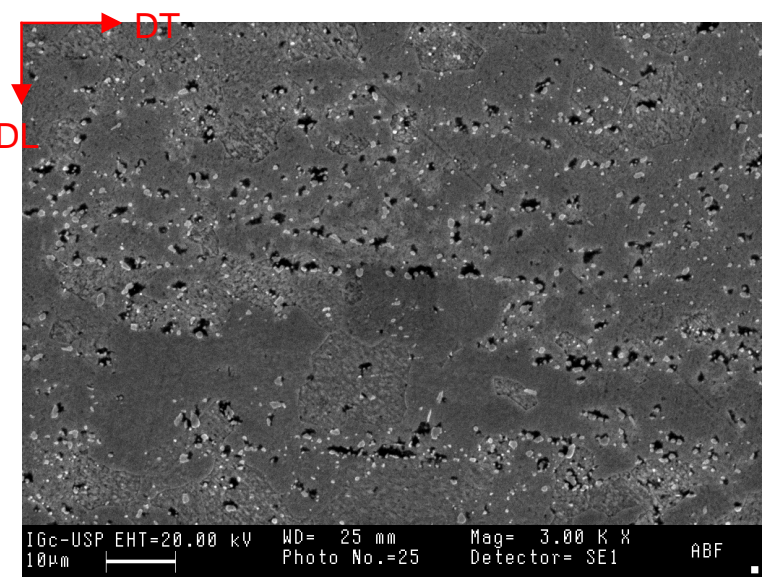

(b)

Figura 6.4: Micrografias em $\mathrm{MO}$ com ataque por reagente Villela das amostras tratadas termicamente do aço AISI 430 a (a) $700^{\circ} \mathrm{C} / 5 \mathrm{~h}$ e (b) B FB. Precipitados escuros são $\mathrm{Cr}_{2} \mathrm{~N}$ e precipitados claros são $(\mathrm{Cr}, \mathrm{Fe})_{23} \mathrm{C}_{6}$.

Da tabela 6.2, foi verificado que em temperaturas inferiores a $800^{\circ} \mathrm{C}$, o aço AISI 430 apresenta uma microestrutura composta por carbonetos do tipo $(\mathrm{Cr}, \mathrm{Fe})_{23} \mathrm{C}_{6}$ e nitretos do tipo $\mathrm{Cr}_{2} \mathrm{~N}$. Em temperaturas superiores a $900{ }^{\circ} \mathrm{C}$ a fração volu métrica do carboneto do tipo $(\mathrm{Cr}, \mathrm{Fe})_{23} \mathrm{C}_{6}$ é reduzida. Pode-se observar, no entanto, um aumento do parâmetro de rede deste carboneto, o qual indica que houve um enriquecimento em cromo do mesmo com o aumento da temperatura. Na tabela 6.3 são apresentados os parâmetros de rede calculados por Rietveld para os difratogramas experimentais em função dos parâmetros de rede apresentados na 
literatura para diversas composições do carboneto do tipo $\mathrm{Cr}_{23-x} \mathrm{Fe}_{x} \mathrm{C}_{6}$.

Tabela 6.3: Relação entre os parâmetros de rede calculados e da literatura para o carboneto do tipo $\mathrm{Cr}_{23-\mathrm{x}} \mathrm{Fe}_{\mathrm{x}} \mathrm{C}_{6}$.

\begin{tabular}{|c|c|c|c|c|}
\hline \multirow{2}{*}{ Amostra } & Experimental - Rietveld & \multicolumn{3}{|c|}{ Literatura } \\
\hline & $\mathbf{a}(\AA)$ & $a(\AA)$ & Composição & ICCD-PDF \\
\hline $600^{\circ} \mathrm{C} / 5 \mathrm{~h}$ & 10.587 & 10.5990 & $\mathrm{Cr}_{15.58} \mathrm{Fe}_{7.42} \mathrm{C}_{6}$ & $078-1502$ \\
\hline $700^{\circ} \mathrm{C} / 5 \mathrm{~h}$ & 10.595 & 10.6199 & $\mathrm{Cr}_{18.93} \mathrm{Fe}_{4.07} \mathrm{C}_{6}$ & $078-1501$ \\
\hline $800^{\circ} \mathrm{C} / 5 \mathrm{~h}$ & 10.605 & 10.6454 & $\mathrm{Cr}_{21.34} \mathrm{Fe}_{1.66} \mathrm{C}_{6}$ & $078-1500$ \\
\hline $900^{\circ} \mathrm{C} / 5 \mathrm{~h}$ & 10.618 & 10.6537 & $\mathrm{Cr}_{22.23} \mathrm{Fe}_{0.77} \mathrm{C}_{6}$ & 078-1499 \\
\hline $1000^{\circ} \mathrm{C} / 5 \mathrm{~h}$ & 10.692 & 10.6595 & $\mathrm{Cr}_{23} \mathrm{C}_{6}$ & $085-1281$ \\
\hline $1100^{\circ} \mathrm{C} / 5 \mathrm{~h}$ & - & & & \\
\hline
\end{tabular}

O parâmetro de rede do carboneto do tipo $(\mathrm{Cr}, \mathrm{Fe}){ }_{23} \mathrm{C}_{6}$ aumenta com 0 aumento da temperatura, indicando que seu teor de $\mathrm{Cr}$ é aumentado até praticamente não existir mais ferro neste carboneto, indicando que o início da dissolução do carboneto do tipo $(\mathrm{Cr}, \mathrm{Fe})_{23} \mathrm{C}_{6}$ ocorre entre $900{ }^{\circ} \mathrm{C}$ e $1000{ }^{\circ} \mathrm{C}$. Avalia-se que a presença de carbonetos do tipo $\mathrm{M}_{23} \mathrm{C}_{6}$ na amostra tratada a $1000{ }^{\circ} \mathrm{C}$ é fruto da cinética lenta de decomposição deste carboneto.

No item 5.3, foi exposto que houve geração de resíduos do processo de dissolução das matrizes com reagente de Berzelius, para extração de precipitados. Os resíduos do processo de dissolução identificados por DR-X dos precipitados extraídos são apresentados na tabela 6.4.

Tabela 6.4: Produtos do processo de extração de precipitados identificados por difração de raios-X do aço AISI 430.

\begin{tabular}{|c|c|}
\hline Condição & Produtos da Extração \\
\hline BQP & $\mathrm{FeO} . \mathrm{Cr}_{2} \mathrm{O}_{3}$ e $\mathrm{Cr}_{2} \mathrm{O}_{3}$ \\
\hline BQB & $\mathrm{CrO}_{3}$ \\
\hline BFB & $\mathrm{CrO}_{3}$ \\
\hline $\mathrm{BQB}+600^{\circ} \mathrm{C} / 5 \mathrm{~h}$ & $\mathrm{Cr}_{2} \mathrm{O}_{3}, \mathrm{FeO} \cdot \mathrm{Cr}_{2} \mathrm{O}_{3}$ e $\mathrm{KCl}$ \\
\hline $\mathrm{BQB}+700^{\circ} \mathrm{C} / 5 \mathrm{~h}$ & $\mathrm{Cu}_{2} \mathrm{Cl}(\mathrm{OH})_{3}$ (Paratacamita) \\
\hline$B Q B+800^{\circ} \mathrm{C} / 5 \mathrm{~h}$ & $\mathrm{Cr}_{2} \mathrm{O}_{3}, \mathrm{Cu}_{2} \mathrm{Cl}(\mathrm{OH})_{3}$ (Paratacamita), $\mathrm{Cu}$ \\
\hline $\mathrm{BQB}+900^{\circ} \mathrm{C} / 5 \mathrm{~h}$ & $\mathrm{Cr}_{2} \mathrm{O}_{3}, \mathrm{Cu}_{2} \mathrm{Cl}(\mathrm{OH})_{3}$ (Paratacamita), $\mathrm{KCl}$ \\
\hline $\mathrm{BQB}+1000^{\circ} \mathrm{C} / 5 \mathrm{~h}$ & $\mathrm{Cr}_{2} \mathrm{O}_{3}, \mathrm{Cu}_{2} \mathrm{Cl}(\mathrm{OH})_{3}$ (Botallackita), $\mathrm{Cu}$ \\
\hline$B Q B+1100 \mathrm{C} / 5 \mathrm{~h}$ & $\mathrm{Cu}_{2} \mathrm{Cl}(\mathrm{OH})_{3}$ (Paratacamita) e FeO. $\mathrm{Cr}_{2} \mathrm{O}_{3}$ \\
\hline
\end{tabular}

Observando-se a tabela 6.4 verifica-se que a menor diversidade de produtos da dissolução foi verificada nas amostras BQB e BFB. Estas amostras foram decapadas quimicamente antes de serem submetidas à dissolução da matriz, enquanto que as demais amostras foram dissolvidas sem a remoção da camada de óxidos formada durante o tratamento térmico e/ou durante a têmpera em água das amostras.

$\mathrm{Na}$ figura 6.5 apresentam-se fotos das amostras antes do processo de 
dissolução dos precipitados e na figura 6.6 apresentam-se fotos dos precipitados extraídos em cada uma das amostras.

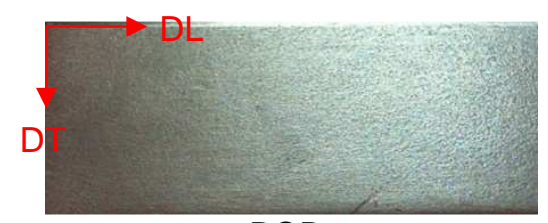

$\mathrm{BQB}$

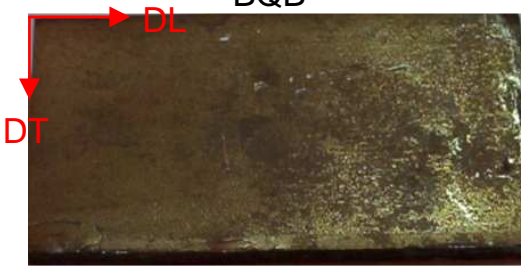

$600^{\circ} \mathrm{C} / 5 \mathrm{~h}$

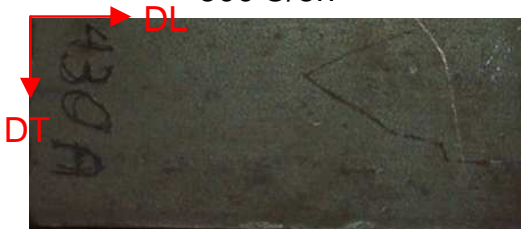

$900{ }^{\circ} \mathrm{C} / 5 \mathrm{~h}$

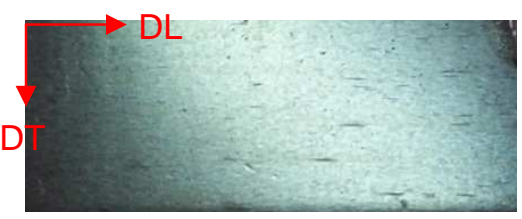

BQP

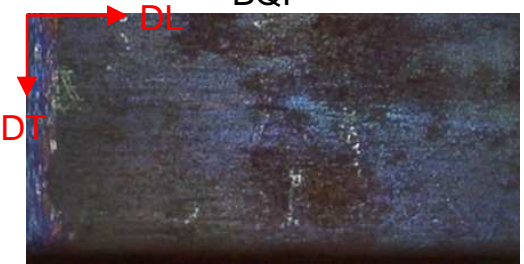

$700^{\circ} \mathrm{C} / 5 \mathrm{~h}$

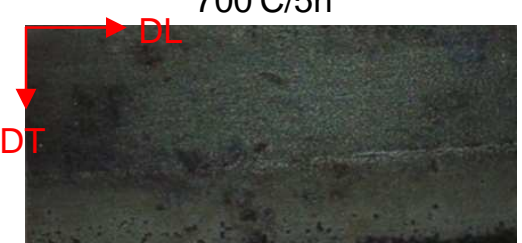

$1000^{\circ} \mathrm{C} / 5 \mathrm{~h}$

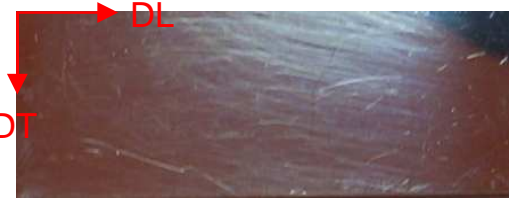

BFB

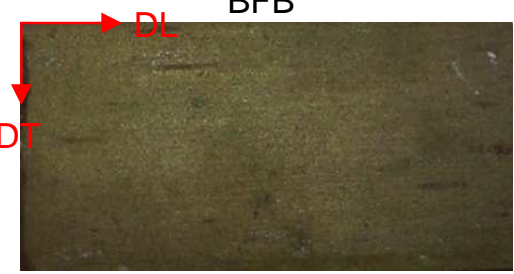

$800^{\circ} \mathrm{C} / 5 \mathrm{~h}$

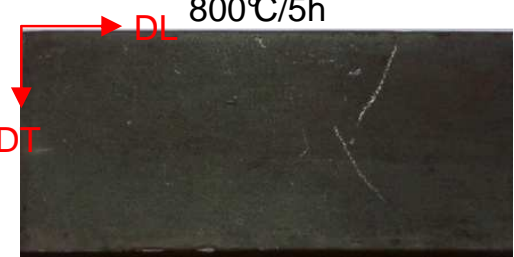

$1100^{\circ} \mathrm{C} / 5 \mathrm{~h}$

Figura 6.5: Fotos das amostras do aço AISI 430 antes e após tratamento térmico.

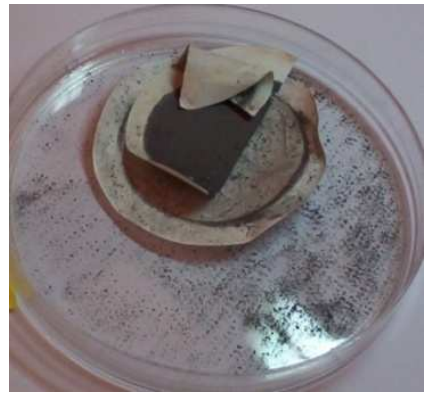

$\mathrm{BQB}$

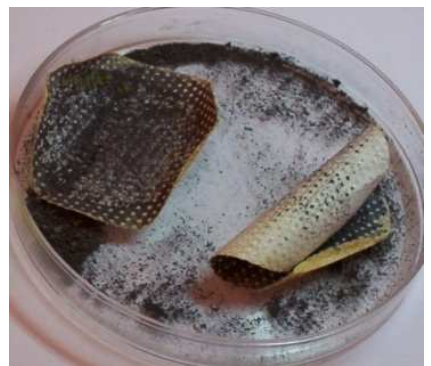

$600^{\circ} \mathrm{C} / 5 \mathrm{~h}$

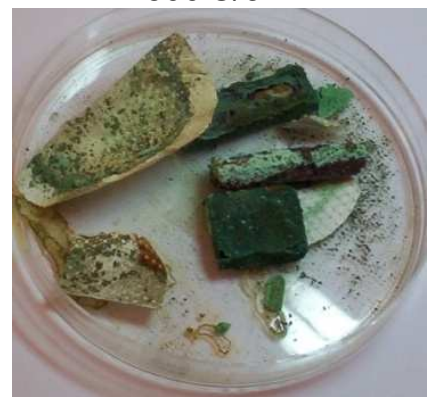

$9000^{\circ} / 5 \mathrm{~h}$

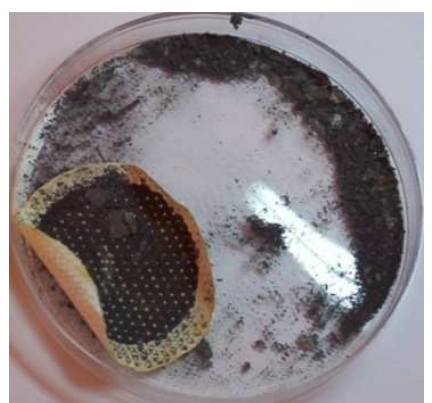

BQP

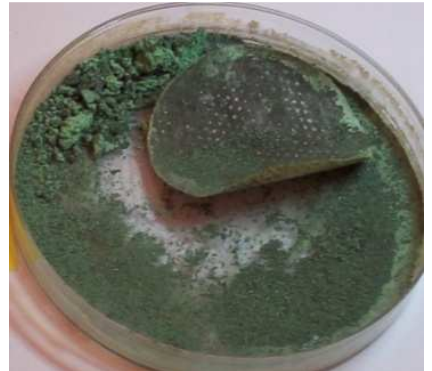

$700^{\circ} \mathrm{C} / 5 \mathrm{~h}$

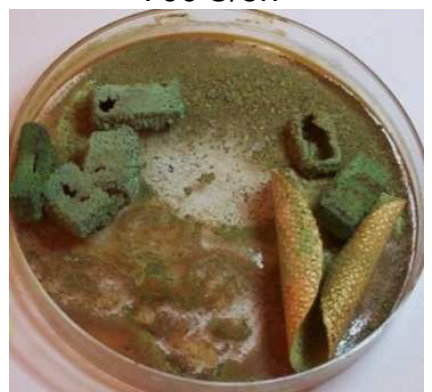

$1000^{\circ} \mathrm{C} / 5 \mathrm{~h}$

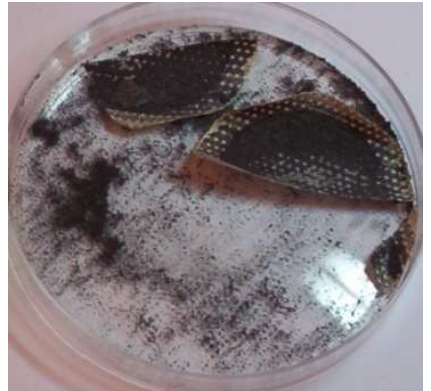

BFB

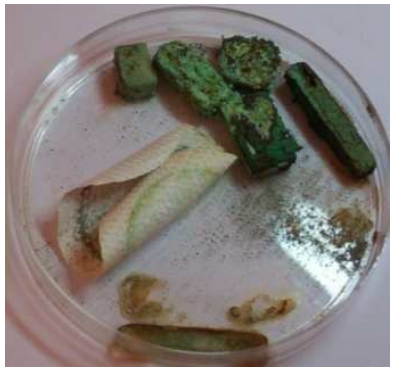

$800^{\circ} \mathrm{C} / 5 \mathrm{~h}$

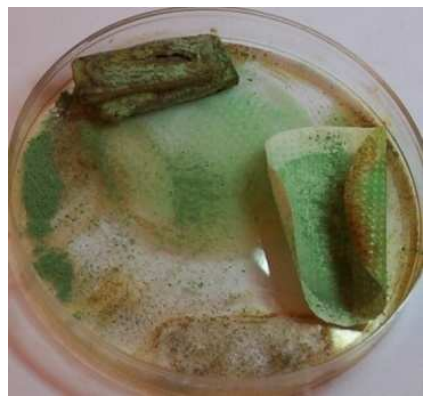

$1100^{\circ} \mathrm{C} / 5 \mathrm{~h}$

Figura 6.6: Fotos dos precipitados extraídos do aço AISI 430 após dissolução em reagente Berzelius e filtração à vácuo. 
Observando-se as figuras 6.5 e 6.6 e comparando-se com os dados da tabela 6.4 , observa-se que quanto maior a temperatura do tratamento térmico, mais reativa foi a superfície da amostra para a oxidação durante o tratamento térmico e têmpera, e por conseqüência mais estável foi o óxido formado. Foi observada a deposição de cobre metálico sobre a camada de óxido das amostras tratadas nas temperaturas de $8^{800} \mathrm{C}$ e $1000^{\circ} \mathrm{C}$, proveniente do cloreto de cobre II $\left(\mathrm{CuCl}_{2}\right)$ presente na composição do reagente de Berzelius. Observa-se na figura 6.6 que os precipitados extraídos das amostras tratadas a $700,800,900,1000$ e $1100^{\circ} \mathrm{C}$ apresentaram coloração verde, em pleno acordo com os resultados da DR-X, indicando a presença de cloreto de cobre hidratado.

$\mathrm{Na}$ figura 6.7 apresentam-se micrografias em $\mathrm{MO}$ dos precipitados extraídos para as amostras de $700^{\circ} \mathrm{C}, 900^{\circ} \mathrm{C}, 1000^{\circ} \mathrm{C}$ e BQP. Observa-se na micrografia da figura 6.7(a) e (b) a presença de Cu metálico, em acordo com os resultados de difração. Em acordo também com os resultados de DR-X observam-se as colorações das micrografias (c) e (d) da figura 6.7 revelando a presença de cloreto de cobre hidratado (verde claro) e de óxido de cromo (preto) respectivamente.

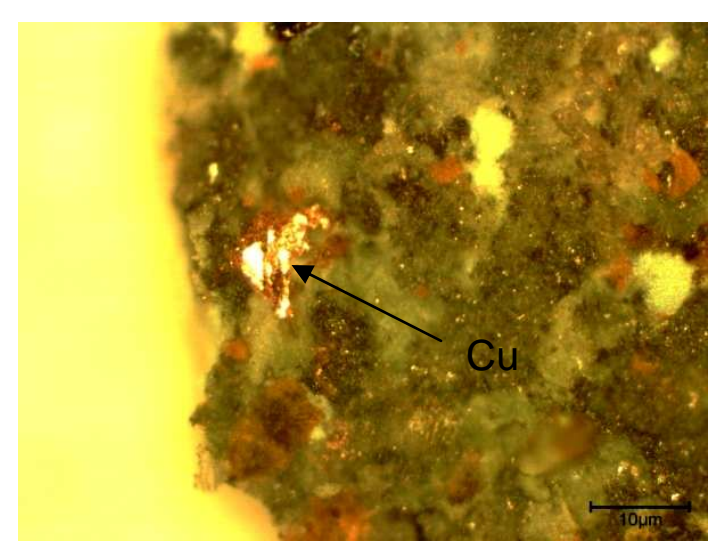

(a)

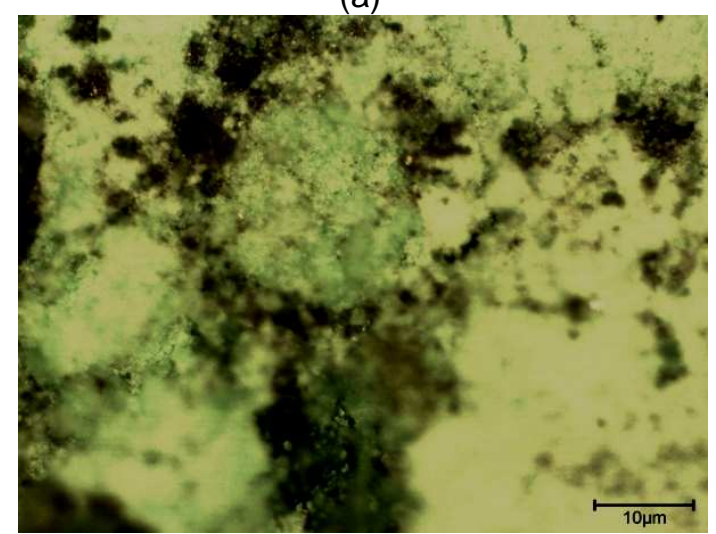

(c)

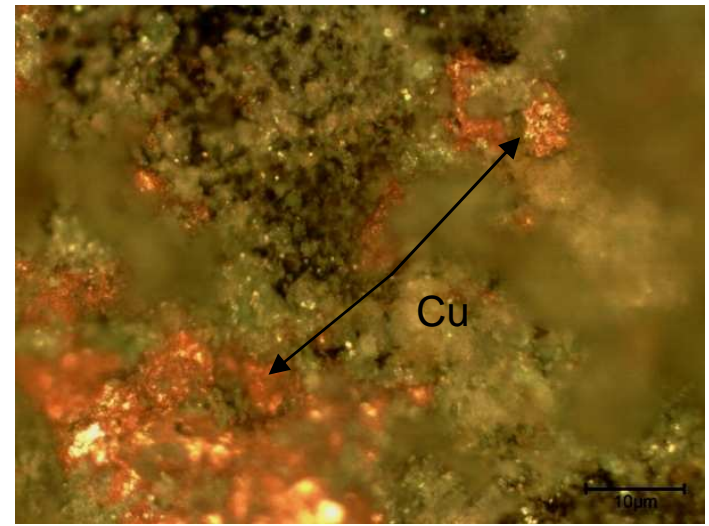

(b)

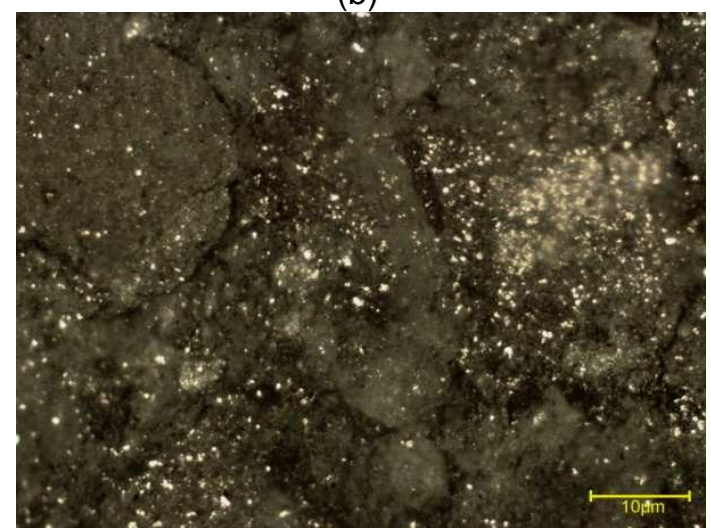

(d)

Figura 6.7: Micrografias em MO dos precipitados extraídos para as amostras tratadas termicamente a (a) $900^{\circ} \mathrm{C} / 5 \mathrm{~h}$, (b) $1000^{\circ} \mathrm{C} / 5 \mathrm{~h}$ e (c) $700^{\circ} \mathrm{C} / 5 \mathrm{~h}$ e para a amostra (d) BQP. 


\subsection{Sumário dos resultados experimentais do aço AISI 430}

Com auxílio do programa ThermoCalc, foi calculada a seqüência de solidificação em equilíbrio do aço AISI 430 (item 5.1) reapresentada na tabela 6.5.

Considerando os dados da tabela 6.3 e os resultados da tabela 6.2 que foram verificados por MO e MEV nas amostras do aço AISI 430 tratadas termicamente e como recebidas, podem ser correlacionados os pontos das inflexões dos três ciclos térmicos do ensaio de DTA (item 5.4) com os respectivos equilíbrios. Na figura 6.8 esta correlação é feita para as temperaturas liquidus e solidus.

Tabela 6.5: Seqüência de solidificação em equilíbrio do aço AISI 430.

\begin{tabular}{|l|c|}
\hline \multicolumn{1}{|c|}{ Transformações de Fases } & T['C] \\
\hline$L \rightarrow L^{\prime}+\delta$ & 1499 \\
\hline$L^{\prime}+\delta \rightarrow L^{\prime}+\delta+M(C, N)$ & 1484 \\
\hline$L^{\prime \prime}+\delta+M(C, N) \rightarrow \delta+M(C, N)$ & 1419 \\
\hline$\delta+M(C, N) \rightarrow \delta+M(C, N)+M n S$ & 1368 \\
\hline$\delta+M(C, N)+M n S \rightarrow \delta+M(C, N)+M n S+\gamma$ & 1267 \\
\hline$\delta+M(C, N)+M n S+\gamma \rightarrow \delta+M(C, N)+M n S+\gamma+M_{23} C_{6}$ & 877 \\
\hline$\delta+M(C, N)+M n S+\gamma+M_{23} C_{6} \rightarrow \delta+M(C, N)+M n S+\gamma+M_{23} C_{6}+M_{2}(C, N)$ & 866 \\
\hline$\delta+M(C, N)+M n S+\gamma+M_{23} C_{6}+M_{2}(C, N) \rightarrow \alpha+M(C, N)+M n S+M_{23} C_{6}+M_{2}(C, N)$ & 840 \\
\hline$\alpha+M(C, N)+M n S+M_{23} C_{6}+M_{2}(C, N) \rightarrow \alpha+M(C, N)+M n S+M_{23} C_{6}+M_{2}(C, N)+\sigma$ & 535 \\
\hline
\end{tabular}

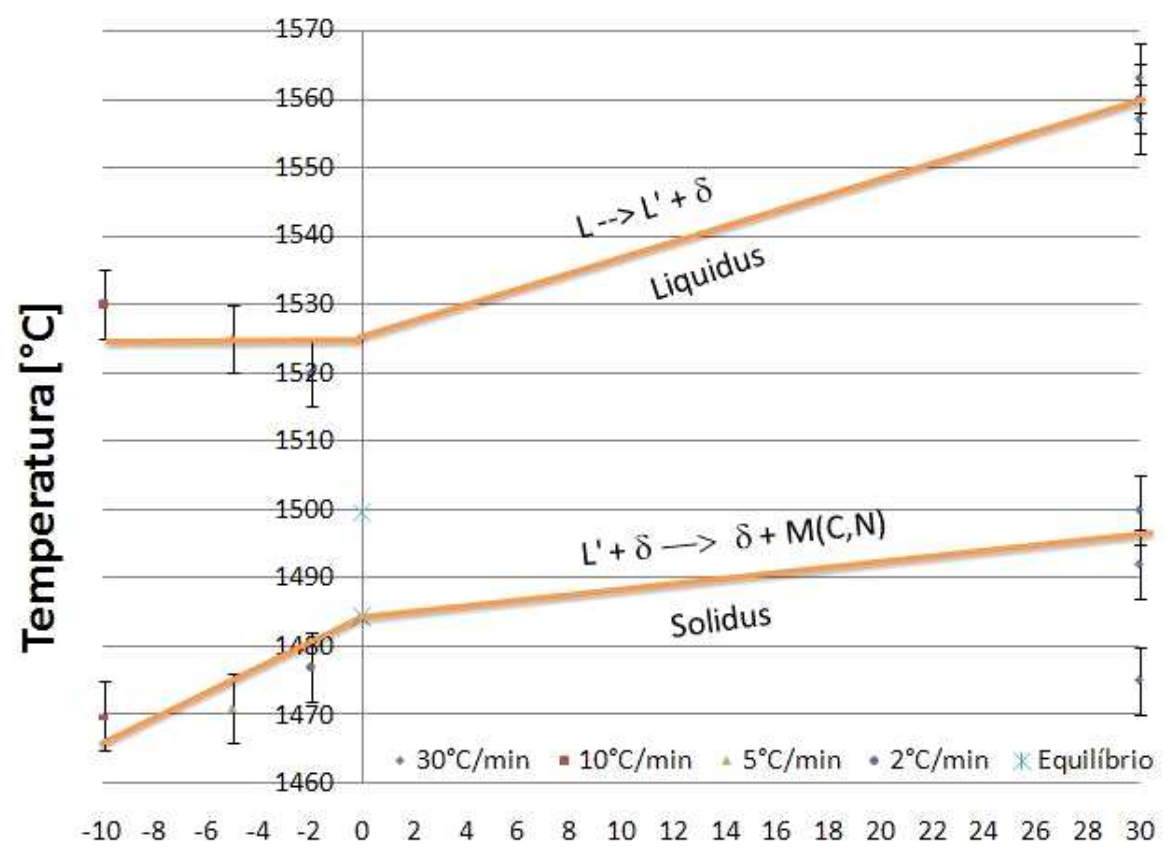

Taxa de Aquecimento / Resfriamento $\left[{ }^{\circ} \mathrm{C} / \mathrm{min}\right]$

Figura 6.8: Variação das temperaturas liquidus e solidus com a taxa de aquecimento/resfriamento para o aço AISI 430.

No gráfico da figura 6.8 pode ser observado que as temperaturas liquidus e solidus do aço apresentaram variação com a taxa de resfriamento/aquecimento 
utilizada em função da necessidade de um super-resfriamento ou superaquecimento constitucional para que as transformações de fases ocorram. Os dados obtidos por DTA não foram suficientes para mensurar a correta variação da temperatura liquidus no resfriamento, sendo esta, portanto, estimada por uma temperatura média $\left(1525^{\circ} \mathrm{C}\right)$ que está cerca de $2^{\circ} \mathrm{C} \mathrm{m}$ ais elevada em relação a temperatura calculada pelo programa ThermoCalc $\left(1499{ }^{\circ} \mathrm{C}\right)$. Os dados obtidos para a temperatura solidus durante os ciclos de resfriamento tendem ao valor calculado como programa ThermoCalc $\left(1484^{\circ} \mathrm{C}\right)$.

O gráfico da figura 6.8 , obtido com os dados experimentais do DTA não foi exatamente o esperado para o comportamento frente à variação da taxa de resfriamento/aquecimento para as temperaturas das transformações de fases. $\mathrm{Na}$ figura 6.9 apresenta-se um esquema do gráfico que seria esperado, ou seja, uma histerese da temperatura de ocorrência da transformação de fase em relação à temperatura de equilíbrio em função da taxa de aquecimento/resfriamento aplicada.

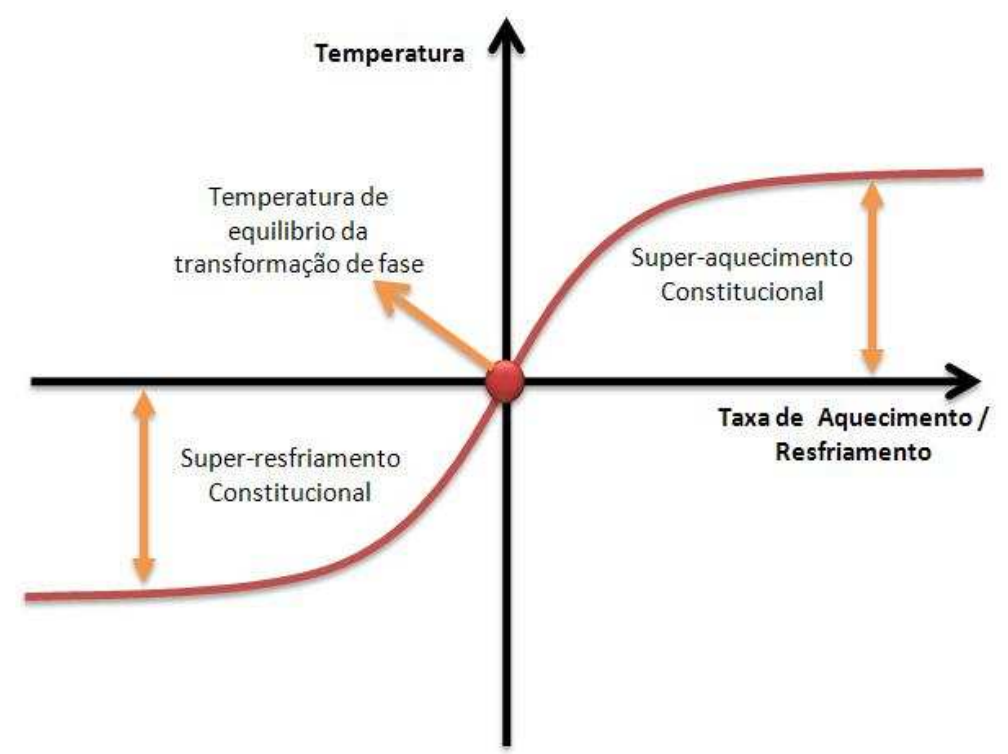

Figura 6.9: Esquema da histerese da temperatura de ocorrência de uma dada transformação de fase, em relação à temperatura de equilíbrio em função da taxa de aquecimento/resfriamento.

As temperaturas das transformações em estado sólido foram também estimadas por DTA e são apresentadas no gráfico da figura 6.10. Como o DTA não é o ensaio de maior precisão para estimar as temperaturas das transformações de fases em estado sólido, as transformações de fases que foram obtidas com 0 programa ThermoCalc foram marcadas neste gráfico como possíveis interpretações dos pontos de inflexão encontrados nos ensaios de DTA através de linhas tracejadas.

A variação das temperaturas das transformações de fases em estado sólido 
com respeito a taxa de aquecimento/resfriamento que foram sugeridas no gráfico da figura 6.10 foram embasadas nos resultados obtidos da caracterização metalográfica das amostras tratadas e como recebidas do aço AISI 430, bem como nos resultados de DR-X dos precipitados extraídos e das matrizes, isto é:

(i) Como verificado na caracterização microestrutural, as amostras tratadas a $1000{ }^{\circ} \mathrm{C} / 5 \mathrm{~h}$ e $1100{ }^{\circ} \mathrm{C} / 5 \mathrm{~h}$ apresentaram as ma iores frações volumétricas de martensita, indicando que antes da têmpera havia equilíbrio ferrita/austenita. $\mathrm{Na}$ amostra tratada a $900{ }^{\circ} \mathrm{C} / 5 \mathrm{~h}$ foi verificada a presença de menor quantidade de fase martensita. Com base nestes dados, podem ser atribuídas as inflexões entre as temperaturas de $9000^{\circ} \mathrm{C}$ a $1250^{\circ} \mathrm{C}$ à transformação $(\alpha \leftarrow \rightarrow \gamma)$.

(ii) As amostras tratadas a $900^{\circ} \mathrm{C} / 5 \mathrm{~h}, 1000^{\circ} \mathrm{C} / 5 \mathrm{~h}$ apr esentaram traços do carboneto do tipo $\mathrm{M}_{23} \mathrm{C}_{6}$, enquanto que as amostras tratadas $700^{\circ} \mathrm{C} / 5 \mathrm{~h}$ e $800^{\circ} \mathrm{C} / 5 \mathrm{~h}$ apresentaram maiores quantidade s deste carboneto, indicando que a decomposição deste carboneto provavelmente deve ocorrer entre $900{ }^{\circ} \mathrm{C}$ e $1000{ }^{\circ} \mathrm{C}$. Co mo a decomposição do carboneto do tipo $\mathrm{M}_{23} \mathrm{C}_{6}$ ocorre em estado sólido, os dados do DTA são pouco confiáveis, no entanto, correlacionando as inflexões encontradas com a temperatura da transformação proveniente da termodinâmica computacional, pode-se estimar (linha tracejada) a variação da temperatura da decomposição do carboneto $\mathrm{M}_{23} \mathrm{C}_{6}$ com a taxa de resfriamento/aquecimento.

(iii) Utilizando-se do mesmo princípio aplicado ao carboneto $\mathrm{M}_{23} \mathrm{C}_{6}$, pode-se estimar (linha tracejada) a variação da temperatura de término da decomposição da fase austenita em função da taxa de resfriamento/aquecimento, visto que a amostra tratada a $900^{\circ} \mathrm{C} / 5 \mathrm{~h}$ apresentou a fase martensita e as amostras tratadas a $700^{\circ} \mathrm{C}$ e $800^{\circ} \mathrm{C}$ não apresentaram esta fase, indicando, portan to, que esta transformação deve ocorrer entre $800^{\circ} \mathrm{C}$ e $900^{\circ}$, poré m em temperatura inferior a decomposição do carboneto do tipo $\mathrm{M}_{23} \mathrm{C}_{6}$. 


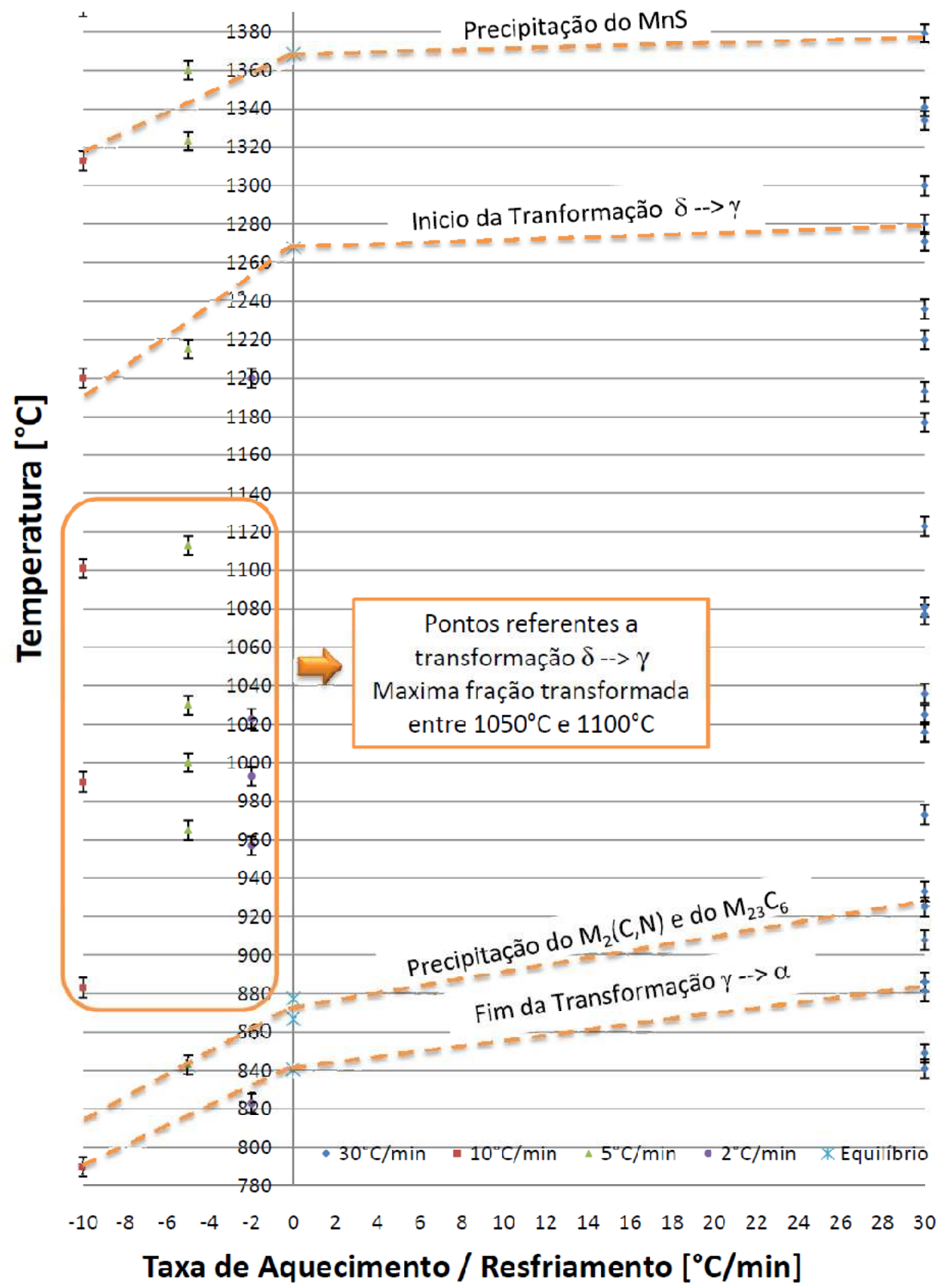

Figura 6.10: Diagrama correlacionando os pontos de inflexão do ensaio de DTA do aço AISI 430 com as temperaturas e as transformações de fases em equilíbrio calculadas com o programa ThermoCalc. As linhas na cor laranja tracejadas têm efeito somente para a indicação da reação, sendo que estas não foram comprovadas com significância pelo ensaio de DTA (inflexões pouco significativas). 


\subsection{Conclusões}

Neste trabalho foi determinada a seqüência de transformações de fases do aço AISI 430 convencional. Dado ao volume de técnicas empregadas, as conclusões serão divididas em itens, sendo no item 7.1 as conclusões referentes às técnicas utilizadas e no item 7.2 referentes à seqüência de transformações de fases do aço AISI 430.

\subsection{Conclusões referentes às técnicas empregadas}

i) As seqüências de transformações de fases dos dois aços puderam ser avaliadas utilizando-se as técnicas de microscopia ótica (MO) e eletrônica de varredura (MEV), difração de raios- $X$, extração de precipitados, análise térmica diferencial (DTA) e modelagem termodinâmica.

ii) $O$ processo de extração de precipitados mostrou-se eficiente para a separação do carbonitreto do tipo $\mathrm{M}_{2}(\mathrm{C}, \mathrm{N})$ e dos carbonetos do tipo $\mathrm{M}_{23} \mathrm{C}_{6}$ da matriz ferrítica e ferrítica/martensítica. Entretanto, foi verificada a presença de resíduos do processo de extração de precipitados, sendo maior a quantidade para as amostras que foram dissolvidas com a camada oxidada do processo de têmpera. Foi observada também a deposição de cobre, proveniente do reagente utilizado para dissolução das matrizes, sobre a camada oxidada das amostras. Assim, para se obter melhores resultados as amostras devem ser decapadas quimicamente ou mecanicamente (lixamento) antes do processo de dissolução.

iii) Os parâmetros empregados na obtenção dos padrões de difração de raios-X mostraram-se adequados à determinação das fases presentes tanto nos precipitados extraídos bem como na determinação da estrutura cristalográfica da matriz, permitindo a separação de duas fases ferrita com parâmetros de rede próximos.

iv) O sistema de vácuo elaborado para o tratamento térmico das amostras mostrou-se eficaz para evitar a oxidação das amostras durante os tratamentos térmicos, sendo verificadas somente oxidações referentes ao processo de têmpera das amostras.

v) Os três ciclos de análise térmica diferencial (DTA) feitos para a amostra na condição BQB mostraram-se parcialmente adequados à determinação das 
temperaturas de transformações de fases deste aço. Os resultados das análises deveriam ter mostrado ciclos de histerese da temperatura das inflexões em função da temperatura de equilíbrio que não foram observados com clareza. No entanto, os resultados experimentais estão em acordo com os resultados da modelagem termodinâmica.

\subsection{Conclusões referentes a seqüência de transformações de fases do aço AISI} 430

Os resultados obtidos para a seqüência de transformações de fases do aço AISI 430 estão em pleno acordo com os resultados da modelagem termodinâmica indicando que as transformações de fases seguem a seguinte seqüência:

\begin{tabular}{|l|c|}
\hline Transformações de Fases & T['C] \\
\hline$L \rightarrow L^{\prime}+\delta$ & 1499 \\
\hline$L^{\prime}+\delta \rightarrow L^{\prime \prime}+\delta+M(C, N)$ & 1484 \\
\hline$L^{\prime \prime}+\delta+M(C, N) \rightarrow \delta+M(C, N)$ & 1419 \\
\hline$\delta+M(C, N) \rightarrow \delta+M(C, N)+M n S$ & 1368 \\
\hline$\delta+M(C, N)+M n S \rightarrow \delta+M(C, N)+M n S+\gamma$ & 1267 \\
\hline$\delta+M(C, N)+M n S+\gamma \rightarrow \delta+M(C, N)+M n S+\gamma+M_{23} C_{6}$ & 877 \\
\hline$\delta+M(C, N)+M n S+\gamma+M_{23} C_{6} \rightarrow \delta+M(C, N)+M n S+\gamma+M_{23} C_{6}+M_{2}(C, N)$ & 866 \\
\hline$\delta+M(C, N)+M n S+\gamma+M_{23} C_{6}+M_{2}(C, N) \rightarrow \alpha+M(C, N)+M n S+M_{23} C_{6}+M_{2}(C, N)$ & 840 \\
\hline$\alpha+M(C, N)+M n S+M_{23} C_{6}+M_{2}(C, N) \rightarrow \alpha+M(C, N)+M n S+M_{23} C_{6}+M_{2}(C, N)+\sigma$ & 535 \\
\hline
\end{tabular}

A caracterização das amostras mostrou que:

i) A amostra BQP apresentou matriz ferrítica com grãos alongados na direção de laminação, a presença de nitretos do tipo $(\mathrm{Cr}, \mathrm{Fe})_{2} \mathrm{~N}$. Nesta amostra não foi observada a presença de carbonetos do tipo $\mathrm{M}_{23} \mathrm{C}_{6}$.

ii) A amostra BQB apresentou matriz ferrítica com grãos parcialmente recristalizados e a presença de nitretos do tipo $(\mathrm{Cr}, \mathrm{Fe})_{2} \mathrm{~N}$ e grande quantidade de carbonetos do tipo $\mathrm{M}_{23} \mathrm{C}_{6}$ distribuídos preferencialmente nas regiões não recristalizadas ou nos contornos de grão.

iii) A amostra BFB apresentou matriz ferrítica com estrutura mais refinada em relação à condição $\mathrm{BQB}$ com a presença nitretos do tipo $(\mathrm{Cr}, \mathrm{Fe})_{2} \mathrm{~N}$ e de carbonetos do tipo $\mathrm{M}_{23} \mathrm{C}_{6}$.

iv) As amostras tratadas a $6000^{\circ} \mathrm{C}$ e $700^{\circ} \mathrm{C}$ apresentar am microestruturas extremamente similares à condição inicial do tratamento térmico (BQB). Observou-se na amostra tratada a $700^{\circ} \mathrm{C}$ o início da recristalização da matriz, com uma pequena redução da fração volumétrica dos precipitados. 
v) Para a amostra tratada a $800^{\circ} \mathrm{C}$ foi observado um maior crescimento de grão em relação à amostra tratada a $700^{\circ} \mathrm{C}$, aliado c om uma maior taxa de recristalização dos grãos.

vi) A amostra tratada a $900^{\circ} \mathrm{C}$ apresentou pouquíssim os precipitados e uma matriz aparentemente dúplex (ferrita/martensita).

vii) As amostras tratadas a $1000^{\circ} \mathrm{C}$ e $1100^{\circ} \mathrm{C}$ apresen taram matriz dúplex (ferrita/martensita) e não foi observada a presença de precipitados visíveis por MO/MEV, no entanto, foram identificados traços do carboneto do tipo $(\mathrm{Cr}, \mathrm{Fe}){ }_{23} \mathrm{C}_{6}$ na amostra tratada a $1000{ }^{\circ} \mathrm{C}$ pela difração de raios $-\mathrm{X}$ dos precipitados extraídos.

Em relação às temperaturas das transformações de fases fora do equilíbrio, foi observado que:

(i) As amostras tratadas a $1000^{\circ} \mathrm{C} / 5 \mathrm{~h}$ e $1100^{\circ} \mathrm{C} / 5 \mathrm{~h}$ ap resentaram as maiores frações volumétricas de martensita, indicando que antes da têmpera havia equilíbrio ferrita/austenita. $\mathrm{Na}$ amostra tratada a $900^{\circ} \mathrm{C} / 5 \mathrm{~h}$ foi verificada a presença de traços da fase martensita. Com base nestes dados estima-se que a transformação $(\alpha \leftarrow \rightarrow \gamma)$ ocorra entre $8^{\circ 77} \mathrm{C}$ e $1^{1267} \mathrm{C}$

(ii) As amostras tratadas a $900^{\circ} \mathrm{C} / 5 \mathrm{~h}$ e $1000^{\circ} \mathrm{C} / 5 \mathrm{~h}$ ap resentaram traços do carboneto do tipo $\mathrm{M}_{23} \mathrm{C}_{6}$, enquanto que as amostras tratadas $700^{\circ} \mathrm{C} / 5 \mathrm{~h}$ e $800^{\circ} \mathrm{C} / 5 \mathrm{~h}$ apresentaram maiores quantidades deste car boneto, indicando que a decomposição deste carboneto provavelmente deve ocorrer entre $900^{\circ} \mathrm{C}$ e $1000^{\circ} \mathrm{C}$.

(iii) A amostra tratada a $900^{\circ} \mathrm{C} / 5 \mathrm{~h}$ apresentou traço s da fase martensita e as amostras tratadas a $700^{\circ} \mathrm{C}$ e $800^{\circ} \mathrm{C}$ não apresentaram esta fase, indicando que o término da transformação da fase austenita para a fase ferrita deve ocorrer entre $800^{\circ} \mathrm{C}$ e $900^{\circ}$, porém em t emperatura inferior a decomposição do carboneto do tipo $\mathrm{M}_{23} \mathrm{C}_{6}$. 


\subsection{Comentários finais e sugestão para trabalhos futuros}

\section{a) Extração de precipitados}

i) Uma fonte de incremento da dificuldade de análise dos padrões de difração de raios- $X$ dos precipitados extraídos veio da não decapagem das amostras antes da dissolução das amostras. Assim as amostras que serão submetidas ao processo de dissolução das matrizes devem obrigatoriamente estar decapadas, seja por via química ou por via mecânica.

ii) A mesma modelagem termodinâmica realizada para o reagente de Berzelius poderia ser aplicada a outros reagentes, sob condições mais controladas, de modo a viabilizar a modelagem do processo de extração de precipitados de modo mais completo, permitindo adequar reagentes para dissolução de fases específicas.

\section{b) Difracão de Raios-X}

i) O uso do método de Rietveld permitiu a separação dos dois tipos de ferrita presentes em diversas amostras estudadas. Também permitiu avaliar com maior precisão a temperatura de decomposição do carboneto do tipo $\mathrm{M}_{23} \mathrm{C}_{6}$ através da comparação entre os parâmetros de rede calculados e os disponíveis na literatura.

\section{c) Análise térmica diferencial (DTA)}

i) A análise térmica diferencial (DTA) mostrou-se uma técnica interessante para a avaliação das temperaturas das transformações de fases presentes no aço em estudo neste trabalho. No entanto, seria relevante repetir os ensaios deste trabalho em um equipamento de DTA calibrado para determinação das entalpias das transformações de fases bem como em um equipamento com DSC (Differential Scanning Calorimetry) acoplado para melhor avaliação das temperaturas das transformações em estado sólido. 


\section{d) Caracterizacão das amostras}

i) Neste trabalho foram feitas análises da microestrutura do material utilizando-se microscopia ótica (MO) e eletrônica de varredura (MEV). Como foram detectados elevados teores de resíduos do processo de extração, optou-se por não realizar a análise dos precipitados extraídos via MEV. Seria interessante refazer a extração de precipitados de algumas amostras, realizando-se antes da dissolução da matriz a decapagem química/mecânica da superfície e fazer a análise dos precipitados extraídos via MEV e via microscopia eletrônica de transmissão (MET).

\section{e) Termodinâmica computacional}

i) O programa ThermoCalc utilizado neste trabalho apresentou-se adequado para avaliação da seqüência de transformações de fases em equilíbrio. No entanto, este programa apresenta mais funções que podem ser exploradas tais como a avaliação de equilíbrio metaestáveis através da imposição de condições de contorno compatíveis e possibilitar avaliação das transformações de fases através da teoria do equilíbrio local ${ }^{(62)}$. Apesar destas qualidades interessantes, o programa ThermoCalc também apresenta inconvenientes quanto ao seu uso e obtenção dos dados desejados. Este programa não apresenta uma interface de programação amigável, sendo que o cálculo é feito através de linhas de códigos internas ao programa, mais que seguem uma linguagem próxima a FORTRAN IV. Outro inconveniente referese ao método de minimização, o qual embora esteja sendo constantemente aprimorado, com uma boa freqüência conduz os cálculos a mínimos falsos, os quais por conseqüência produzem dados de equilíbrio incorretos, e por vezes absurdos. Uma variável não menos importante é o banco de dados termodinâmicos que se utiliza para os cálculos. O banco de dados apresenta um conjunto de dados, os quais se não devidamente atualizados, e certificados para um dado intervalo de utilização (temperatura, pressão, e composição), podem gerar dados incorretos e conduzir a conclusões erradas. Assim, de um modo geral, o uso deste programa traz muitas vantagens, mais deve ser feito com cautela e verificando-se, ponto a ponto, cada informação obtida, quanto a sua coerência com os dados efetivamente conhecidos experimentalmente e no conjunto com os demais dados calculados. 


\section{$\underline{\text { Anexos }}$}

\section{Anexo 1: Cartões de estrutura utilizados no refino pelo método de Rietveld}

\section{a) Fase $\mathrm{Cu}_{2} \underline{\mathrm{Cl}(\mathrm{OH})_{3}} \underline{\text { - Botallackite }}$}

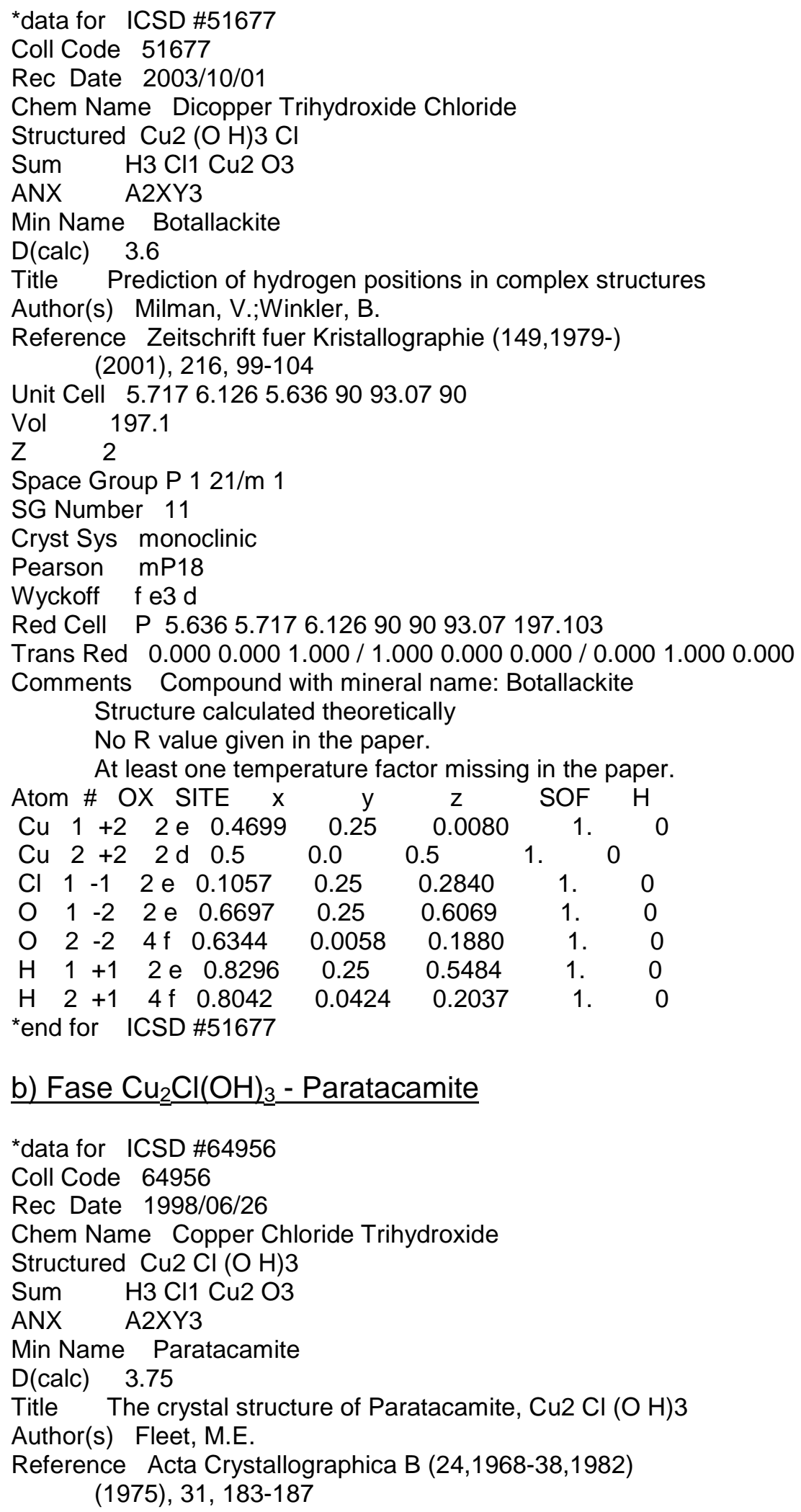


Unit Cell 6.827(3) 6.827(3) 14.041(6) 90. 90.120.

Vol $\quad 566.75$

Z 6

Space Group R -3 m H

SG Number 166

Cryst Sys trigonal/rhombohedral

Pearson hR18

Wyckoff he c b

$R$ Value 0.022

Red Cell RH 6.118 6.118 6.118 67.815 67.815 67.815 188.915

Trans Red $0.333-0.330-0.330 /-0.660-0.330-0.330 / 0.3330 .667-0.330$

Comments PDF 25-1427, for superstructure with a doubled cp. 1810

For split O in .21.79 .065 (76\%) and .195, .805 .048 (24\%)

$\mathrm{R}=0.021$

Compound with mineral name: Paratacamite

The structure has been assigned a PDF number: 25-1427

Calculated density unusual but tolerable.

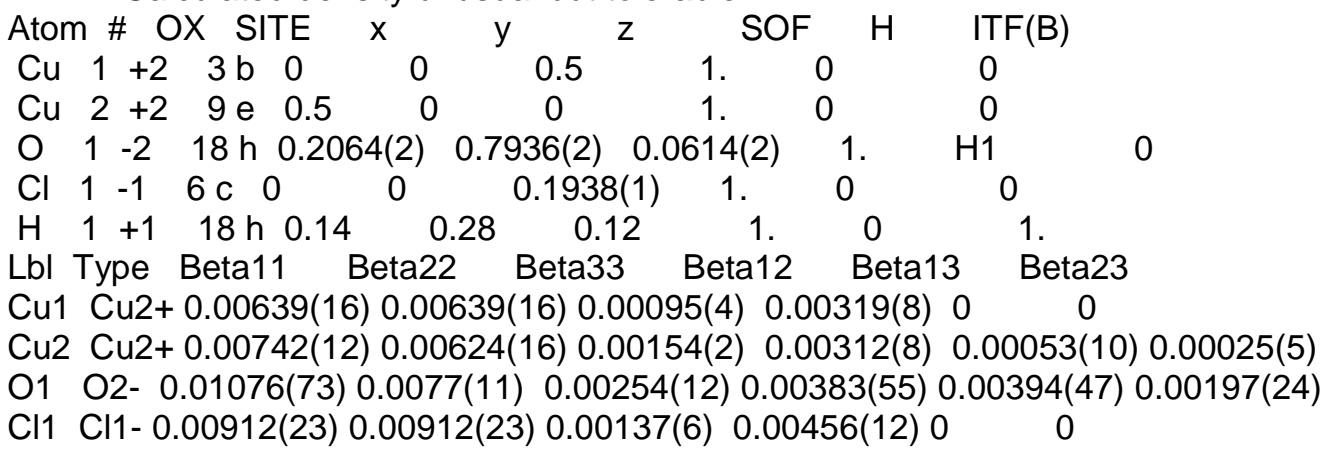

*end for ICSD \#64956

\section{c) $\mathrm{FeO} . \mathrm{Cr}_{2} \underline{\mathrm{O}}_{3}$}

*data for ICSD \#56119

Coll Code 56119

Rec Date 2003/04/01

Chem Name Iron Dichromium Oxide

Structured $\mathrm{Fe} \mathrm{Cr} 2 \mathrm{O} 4$

Sum $\quad \mathrm{Cr} 2 \mathrm{Fe} 1 \mathrm{O} 4$

ANX AB2X4

Min Name Chromite

$\mathrm{D}$ (calc) $\quad 5.09$

Title Roentgenographische Strukturuntersuchungen der Mineralien der

Spinelltyp

Spinellgruppe und von synthetisch dargestellten Substanzen vom

Author(s) Holgersson, S.

Reference Lunds Universitets Arsskrift, Avdelningen 2. Kunglig Fysiografiska Salskapets i Lund:

Handlinger

(1927), 23, 1-9

Unit Cell 8.357(4) 8.357 8.357 90.90. 90.

Vol $\quad 583.65$

Z 8

Space Group F d -3 m S

SG Number 227

Cryst Sys cubic

Pearson cF56

Wyckoff e d a

Red Cell F 5.909 5.9095.909606060145.912

Trans Red $0.5000 .5000 .000 / 0.0000 .5000 .500 / 0.5000 .0000 .500$

Comments Compound with mineral name: Chromite

The structure has been assigned a PDF number: 34-140

Structure type : Al2MgO4

No $R$ value given in the paper.

At least one temperature factor missing in the paper. 


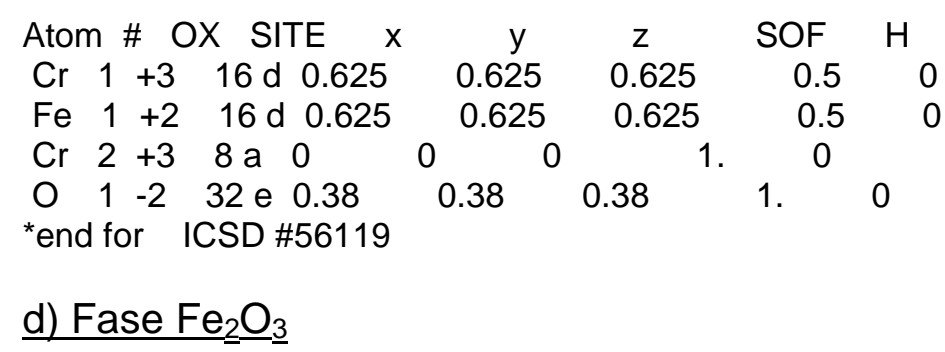

*data for ICSD \#96076

Coll Code 96076

Rec Date 2004/04/01

Chem Name Iron(III) Oxide - Alpha Hp1

Structured $\mathrm{Fe} 2 \mathrm{O} 3$

Sum $\quad \mathrm{Fe} 2 \mathrm{O} 3$

ANX A2X3

Min Name Hematite

$\mathrm{D}$ (calc) $\quad 6.16$

Title High-pressure structural studies of hematite $\mathrm{Fe} 2 \mathrm{O} 3$

Author(s) Rozenberg, G.Kh.;Dubrovinskii, L.S.;Pasternak, M.P.;Naaman, O.; Le Bihan, T.;Ahuja, R.

Reference Physical Review, Serie 3. B - Condensed Matter (18,1978-) (2002), 65, 064112-1-064112-8

Unit Cell 4.8369(18) 4.8369(18) 12.75209090120

Vol 258.37

Z 6

Space Group R -3 c H

SG Number 167

Cryst Sys trigonal/rhombohedral

Pearson hR10

Wyckoff e c

$R$ Value 0.004

Red Cell RH 4.836 4.836 5.085 61.606 61.606 60 86.124

Trans Red $0.0001 .0000 .000 / 1.0001 .0000 .000 / 0.3330 .667-0.330$

Comments Compound with mineral name: Hematite

Pressure in MPa: 55400

Rietveld profile refinement applied

Synchrotron radiation (powder)

At least one temperature factor missing in the paper.

Atom \# OX SITE $x \quad y \quad z$ SOF $H$

$\mathrm{Fe} 1+3 \quad 12 \mathrm{c} 0 . \quad 0 . \quad 0.3528(3) \quad 1.0$

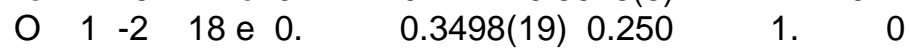

*end for ICSD \#96076

\section{e) Fase $\mathrm{Cr}_{2} \underline{\mathrm{O}}_{3}$}

*data for ICSD \#250078

Coll Code 250078

Rec Date 2004/04/01

Chem Name Chromium Oxide

Structured $\mathrm{Cr} 2 \mathrm{O} 3$

Sum $\mathrm{Cr} 2 \mathrm{O} 3$

ANX A2X3

Min Name Eskolaite

$\mathrm{D}$ (calc) $\quad 5.25$

Title Electron density in synthetic escolaite $\mathrm{Cr} 2 \mathrm{O} 3$ with a corundum structure and its relation to antiferromagnetic properties

Author(s) Belokoneva, E.L.;Shcherbakova, Yu.K.

Reference Zhurnal Neorganicheskoi Khimii (2003), 48, 960-968

Unit Cell 4.953(2) 4.953(2) 13.578(4) 9090120

Vol $\quad 288.47$ 
Space Group R -3 c H

SG Number 167

Cryst Sys trigonal/rhombohedral

Pearson hR10

Wyckoff e c

$R$ Value 0.022

Red Cell RH 4.953 4.9535.35362.44662.446 60 96.157

Trans Red $1.0000 .0000 .000 / 1.0001 .0000 .000 / 0.6670 .3330 .333$

Comments Electron structure calculation

Compound with mineral name: Eskolaite

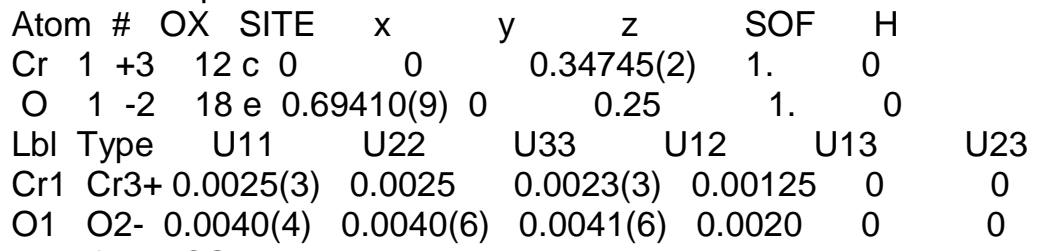

*end for ICSD \#250078

\section{f) Fase $\mathrm{CrO}_{3}$}

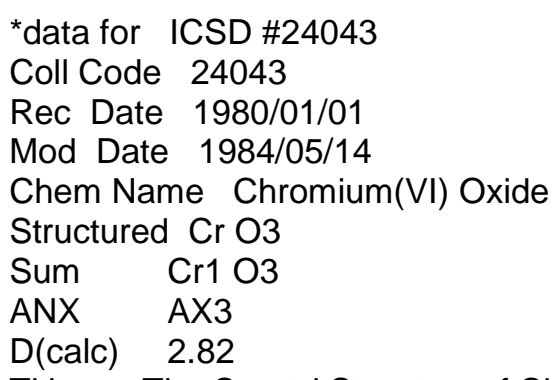

Title The Crystal Structure of Chromium Trioxide

Author(s) Bystroem, A.;Wilhelmi, K.A.

Reference Acta Chemica Scandinavica (1-27,1973-42,1988) (1950), 4, 1131-1141

Unit Cell 4.789(5) 8.557(5) 5.743(5) 90. 90. 90.

Vol $\quad 235.35$

Z 4

Space Group C 2 c m

SG Number 40

Cryst Sys orthorhombic

Pearson oS16

Wyckoff b3 a

Red Cell C 4.7894 .9025 .7439089 .999119 .233117 .673

Trans Red $1.0000 .0000 .000 /-0.500-0.5000 .000 / 0.0000 .000-1.000$

Comments No $R$ value given in the paper.

At least one temperature factor missing in the paper.

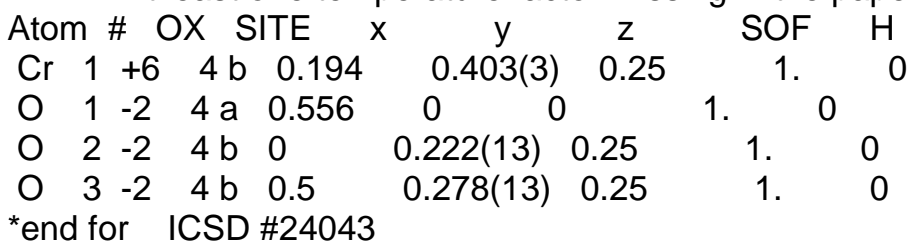

\section{g) Fase $\mathrm{KCl}$}

*data for ICSD \#44281

Coll Code 44281

Rec Date 2000/07/15

Chem Name Potassium Chloride

Structured $\mathrm{K} \mathrm{Cl}$

Sum $\quad \mathrm{Cl} 1 \mathrm{~K} 1$

ANX AX 
Min Name Sylvine

$\mathrm{D}$ (calc) 2.02

Title Direct determination of self-consistent total energies and and charge densities of solids: a study of the cohesive properties of the alkali

halides

Author(s) Cortona, P.

Reference Physical Review, Serie 3. B - Condensed Matter (18,1978-) (1992), 46, 2008-2014

Unit Cell 6.26 6.26 6.26 90. 90. 90.

Vol 245.31

Z 4

Space Group F m -3 m

SG Number 225

Cryst Sys cubic

Pearson cF8

Wyckoff b a

Red Cell F 4.426 4.426 4.42659.99959.999 59.99961.329

Trans Red $0.5000 .5000 .000 / 0.0000 .5000 .500 / 0.5000 .0000 .500$

Comments Measured cell at $298 \mathrm{~K}: 6.29$; at $0 \mathrm{~K}: 6.25$

Compound with mineral name: Sylvine

The structure has been assigned a PDF number: 41-1476

Structure calculated theoretically

Structure type : $\mathrm{NaCl}$

No $R$ value given in the paper.

At least one temperature factor missing in the paper.

Atom \# OX SITE $x \quad y \quad z \quad$ SOF $H$

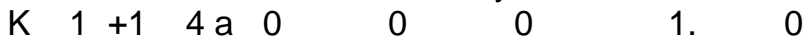

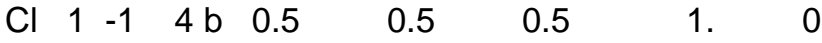

*end for ICSD \#44281

\section{h) Fase $\mathrm{Cu}$}

*data for ICSD \#53247

Coll Code 53247

Rec Date 2002/04/01

Chem Name Copper

Structured $\mathrm{Cu}$

Sum Cu1

ANX N

Min Name Copper

$\mathrm{D}$ (calc) 8.95

Title High-temperature expansion of six metallic elements measured by dilatation method and $X$-ray diffraction

Author(s) Suh, I.-K.;Ohta, H.;Waseda, Y.

Reference Journal of Materials Science

(1988), 23, 757-760

Annales Academiae Scientiarum Fennicae, Series A6: Physica (1967), 223, 1-10

Unit Cell 3.613 3.613 3.613 90. 90. 90 .

Vol $\quad 47.16$

Z 4

Space Group F m -3 m

SG Number 225

Cryst Sys cubic

Pearson cF4

Wyckoff a

Red Cell F 2.5542 .5542 .55460606011 .791

Trans Red $0.5000 .5000 .000 / 0.0000 .5000 .500 / 0.5000 .0000 .500$

Comments Cell at $777 \mathrm{~K}: 3.644$, at $1076 \mathrm{~K}: 3.667$, at $1343 \mathrm{~K}: 3.692$

Cell from 2nd reference: 3.61443 at $296 \mathrm{~K}, 3.6247$ at $449 \mathrm{~K}$,

3.6321 at $550 \mathrm{~K}, 3.6357$ at $607 \mathrm{~K}, 3.6483$ at $779 \mathrm{~K}$

Compound with mineral name: Copper

The structure has been assigned a PDF number: 4-836 
Temperature in Kelvin: 293

Structure type : $\mathrm{Cu}$

No $R$ value given in the paper.

At least one temperature factor missing in the paper.

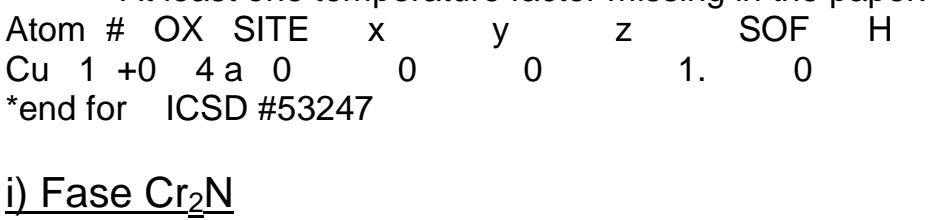

*data for ICSD \#67400

Coll Code 67400

Rec Date 1991/07/10

Chem Name Chromium Nitride (2/1)

Structured $\mathrm{Cr} 2 \mathrm{~N}$

Sum $\quad \mathrm{Cr} 2 \mathrm{~N} 1$

ANX NO2

$\mathrm{D}$ (calc) $\quad 6.79$

Title Structure refinement for $\mathrm{Cr} 2 \mathrm{~N}$

Author(s) Kim, S.-J.;Marquart, T.;Franzen, H.F.

Reference Journal of the Less-Common Metals (1990), 158, 9-10

Unit Cell 4.752(3) 4.752(3) 4.429(4) 90. 90. 120.

Vol 86.61

Z 3

Space Group P -3 1 m

SG Number 162

Cryst Sys trigonal/rhombohedral

Pearson hP9

Wyckoff $\mathrm{kda}$

$R$ Value 0.037

Red Cell P 4.4294 .7524 .752120909086 .614

Trans Red $0.0000 .0001 .000 / 1.0000 .0000 .000 / 0.0001 .0000 .000$

Comments At least one temperature factor is implausible or meaningless but agrees with the value given in the paper.

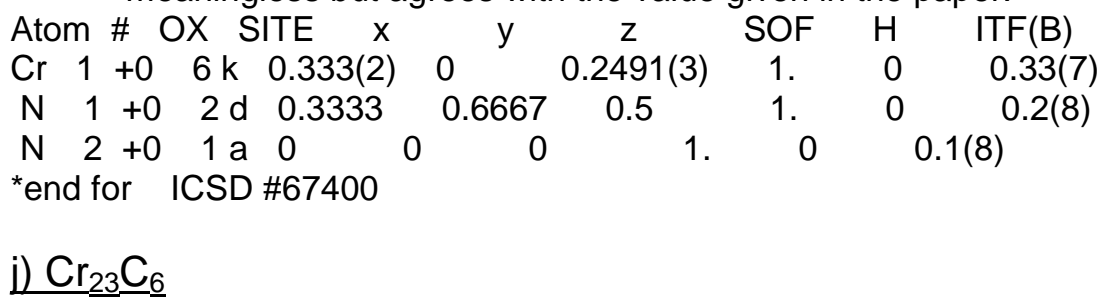


Wyckoff $\mathrm{hfeca}$

$R$ Value 0.056

Red Cell F 7.5307.5307.530606060301.987

Trans Red $0.5000 .5000 .000 / 0.0000 .5000 .500 / 0.5000 .0000 .500$

Comments Neutron diffraction (powder)

Structure type : Cr23C6

At least one temperature factor missing in the paper.

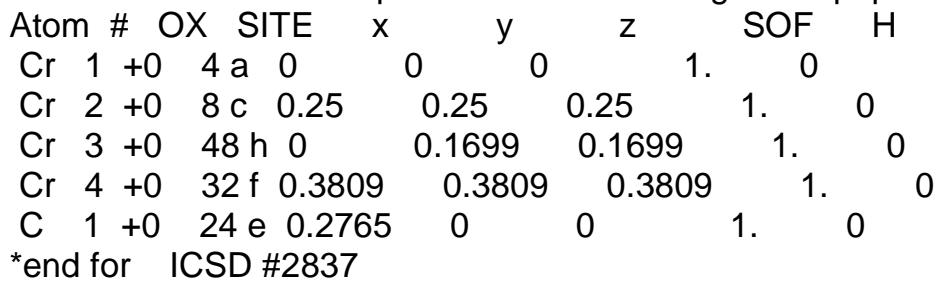

\section{k) Fase Ferrita $(\mathrm{Fe}-\alpha)$}

data for ICSD \#53451

Coll Code 53451

Rec Date 2003/04/01

Mod Date 2004/04/01

Chem Name Iron - Alpha

Structured $\mathrm{Fe}$

Sum Fe1

ANX N

$\mathrm{D}$ (calc) $\quad 7.87$

Title Ueber die Temperaturabhaengigkeit der Gitterparameter von Eisen, Kobalt und Nickel im Bereich hoher Temperaturen

Author(s) Kohlhaas, R.;Duenner, P.;Schmitz-Pranghe, N.

Reference Zeitschrift fuer Angewandte Physik

(1967), 23, 245-249

Transactions of the Metallurgical Society of Aime

(1965), 233, 1519-1525

Unit Cell 2.86652 .8665 2.8665 90. 90. 90.

Vol 23.55

Z 2

Space Group I m -3 m

SG Number 229

Cryst Sys cubic

Pearson $\mathrm{cl} 2$

Wyckoff a

Red Cell I 2.4822 .4822 .482109 .471109 .471109 .47111 .777

Trans Red $0.5000 .500-0.500 /-0.5000 .5000 .500 / 0.500-0.5000 .500$

Comments Stable below $1183 \mathrm{~K}$, cell at $93 \mathrm{~K}: 2.8613$, at $193 \mathrm{~K}$ : 2.8627 , at $588 \mathrm{~K}: 2.8775$, at $861 \mathrm{~K}: 2.8890$, at $1180 \mathrm{~K}$ :

2.9005

Cell from 2nd ref. (Gorton et al.) at $298 \mathrm{~K}: 2.8670$, at 378

$\mathrm{K}: 2.8690$. at $988 \mathrm{~K}: 2.8973$, at $988 \mathrm{~K}: 2.8973$, at $1073 \mathrm{~K}$ :

2.9013

PDF 6-696

The structure has been assigned a PDF number: 6-696

Structure type : W

X-ray diffraction (powder)

No $R$ value given in the paper.

At least one temperature factor missing in the paper.

Atom \# OX SITE $x$ y $z$ SOF $H$

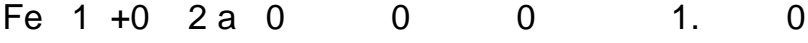

*end for ICSD \#53451 


\section{Referências Bibliográficas}

1. ASM Handbook. 1992. pp. 2-43, 2-49, 2-109, 2-102, 2-155. Vols. III - Phase Diagrams.

2. Wu, P.D., et al. Analysis of ridging in ferritic stainless steel sheet. Materials Science and Engineering A. 2006, pp. 300-5.

3. ThermoCalc. ThermoCalc. ThermoCalc. [Online] Maio de 2007. http://www.thermocalc.se.

4. SSUB3, Banco de dados termodinâmicos. s.I. : ThermoCalc, 2004.

5. Feldstein, J e Lake, F. A new constitution diagram for predicting ferrite content of stainless steels weld metals. Materials and Design. 1993, Vol. 14, 6, pp. 345-348.

6. Liu, $\mathbf{X}$, et al. Structure changes of 430 stainless steel in heating process. Jounal of University Science and Tech. Beijing. 2008, Vol. 15, 1, pp. 34-37.

7. MacDonald, W. D, Carpenter, G. J. C e Saimoto, S. Using strain rate sensivity measuraments to determine phase relations in A430 stainless steel. Materials Science and Engineering A. 1995, Vol. 190, pp. 33-42.

8. Sung, J. H, et al. Phase Changes of the AISI430 ferritic stainless steels after hightemperature gas nitridind and tempering heat treatment. Materials Science and Engineering A. 2008, Vol. 489, pp. 38-43.

9. Ramirez, M.F.G. Estudo da transformação durante o resfriamento continuo e da microestrutura do aço microligado X80 utilizado na construção de tubos para o transporte de gas natural e petroleo. Departamento de Engenharia Metalurgica e de Materiais, Escola Politécnica da Universidade de São Paulo. São Paulo : s.n., 2008. p. 159, Dissertação de Mestrado.

10. Cullity, B. D. Elemens of X-ray diffaction. s.I. : Addison-Wesley Publishing Company, Inc., 1978. 0-201-01174-3.

11. Shull, R. D. Application of Thermal Analysis Techniques to Phase Diagram Determination. [A. do livro] R. D Shull e A. Joshi. Thermal Analysis in Metallurgy. s.I. : The Minerals and Materials Society, 1992, pp. 95-119.

12. Boettinger, W. J, et al. DTA and Heat-Flux DSC Measurements of Alloy Melting and Freezing. [A. do livro] Methods for Phase Diagram Determination. Zhao, J-C. Latham : Elsevier, 2007, pp. 151-221.

13. Perepezko, J. H. Thermal Analysis of Solidification Kinetics. [A. do livro] R. D Shull e A. Joshi. Thermal Analysis in Metallurgy. 1992, pp. 121-153. 
14. Jin-Cheng, $\mathbf{H}$, et al. ThermoCalc Calculation and experimental study of microstructures of SUS410S and SUS430 ferrire stanless steels at high temperature. POrcoceedings of Sino-Swedish Structural Materials Symposium. 2007, pp. 183-188. 15. Burke, J. E e Turnbull, D. Recrystalization and grain growth. London: Pergamon Press, 1952. pp. 220-292. Vol. 3.

16. Cahn, R. W e Haasen, P. Physical Metallurgy. Amsterdan (Holland) : Elsevier, 1996. pp. 1556-1620. Vol. II.

17. Hillert, M. On the theory of normal and abnormal grain growth. Acta Metallugica. 1965, Vol. 13, pp. 227-238.

18. Padilha, A. F e Siciliano Jr, F. Encruamento, recristalização, crecsimento de grão e textura. 3a Edição. São Paulo: Associação Brasileira de Metalurgia e de Materiais, 2005.

19. Sinclair, C. W, et al. Recrystallization of stabilised ferritic steel sheet. Metallurgical and Materials Transactions A. 2005, Vol. 36, pp. 3205-3215.

20. Weygand, D, Bréchet, $\mathbf{Y}$ e Lépinoux, J. Mechanisms and Kinetics of Recrystallisation: A Two Dimensional Vertex Dynamics Simulation. INTERFACE SCIENCE. 2001, Vol. 9, pp. 311-317.

21. Steels, Metallography and Microstructures of Stainless Steels and Maraging. ASM Metals Handbook. 1992. pp. 1582-1662. Vol. 9.

22. Burke, K. E. Chemical Extraction of refractory inclusions from iron- and nickelbase alloys. Metallography. 1975, Vol. 8, pp. 473-488.

23. Gordon, W e Bennekom, A.van. Review of stabilization of ferritic stainless steels. Materials Science and Technology. 1996, Vol. 12, pp. 126-131.

24. Costa e SIva, A.L.V e Mei, P.R. Aços e Ligas Especiais. 2a edição. São Paulo : Blücher, 2006. pp. 415-416.

25. Gonçalves, I.N., et al. Study of ridging phenomenon in ferritic stainless steel using EBSD. Acta Microscopica. Supplement C, 2003, Vol. 12, pp. 187-8.

26. Shin, H-J: An, J-K, Park, S. H e Lee, D. N. The effect of texture on ridging of ferritic stainless steel. Acta Materialia. 2003, Vol. 51, pp. 4693-4706.

27. Liu, W.J. e Jonas, J.J. A Reexamination of the Gibbs Energies of Formation of TiS and Characterization of Ti4C2S2 in Austenite. ISIJ International. 1994, Vol. 34, pp. 761-763.

28. - Calculation of the Ti(CyNl-y)-Ti4C2S2-MnS Austenite Equilibrium in TiBearing Steels. Metallurgical Transactions A. 1989, Vol. 20A, pp. 1361-1374. 
29. Liu, W.J., Yue, S. e Jonas, J.J. Characterization of Ti Carbosulfide Precipitation in Ti Microalloyed Steels. Metallurgical Transactions A. 1989, Vol. 20A, pp. 19071915.

30. Wallen, B e Olssen, J. Handbook of Stainless Steels. New York : McGraw-Hill, 1977. pp. 16-77.

31. Sim, G. M, et al. Effect of $\mathrm{Nb}$ precipitate coersening on the high temperature strength in $\mathrm{Nb}$ conteining ferritic stainless steels. Materials Sccience and Engineering A. 2005, Vol. 396, pp. 159-165.

32. Fujita, N, Ohmura, $\mathrm{K}$ e Yamamoto, A. Changes of microstructure and high temperature properties during high temperature service of $\mathrm{Nb}$ added ferritic stainless steels. Materias Science and Engineering A. 2003, Vol. 351, pp. 272-281.

33. Fujita, N, Badeshia, H. K. D. H e Kikuchi, M. Precipitation sequence in niobiunalloyed ferritic stainless steel. Modelling Simul. Sci. Eng. 2004, Vol. 12, pp. 273-284.

34. Yan, $\mathbf{H}, \mathbf{B i}, \mathbf{H}$ e $\mathbf{X u}, \mathbf{Z}$. Microestructure and Texture of $\mathrm{Nb}+\mathrm{Ti}$ stabilized ferritic stainless steel. Materials Characterization. XX, 2008, Vol. XX. doi: 10.1016/j.matchar.2008.03.018.

35. Xiang-Mi, Y, Zhou-hua, J e Hua-Bing, L. Ultra-pure ferritic Stainless steelsgrade, refining, operation, and application. Journal of iron and steel research. 2007, Vol. 14, 4, pp. 24-30.

36. Askoy, M, Kuzucu, V e Korkut, M. H. The influence of strong carbide-forming elements and homogenization on the wear resistance of ferritic stainless steel. Wear. 1997, Vol. 211, pp. 265-270.

37. Meineke, K. Z. anal. Chem. 1871, Vol. 10, p. 280.

38. Berzelius, J. J. Lehrbuch der Chemie. Drittle Band. Dresden und Leipzig: Arnoldischen Buchhandlung, 1845. pp. 39,91,786.

39. Rietveld, H.M. A Profile Refinament Method for Nuclear and Magnectic Structures. J. Appl. Cryst. 1969, Vol. 2, pp. 65-71.

40. Coelho, Alan. TOPAS Academic - Technical Reference - Version 4.1. Bisbane : s.n., 2007. p. 127p. Manual do programa TOPAS Academic.

41. Dolllase, W. A. Correction of Intensities for Prefered Orientation on Powder Diffractometry: Application of the March Model. J. Appl. Cryst. 1986, 19, pp. 267-272. 42. Agren, J. Kinectis of carbide dissolution. Scandinavian Journal of Metallurgy. 1990, Vol. 19, pp. 2-8. 
43. Farina, A.B. Etude de la Transfomation Massive Ferrite delta --> austénite en les aciers inoxydables. INPG et Ugine\&ALZ - Groupe Arcelor. Grenoble - France : s.n., 2006. p. 148, Rapport de fin de Stage - Confidentiel.

44. Fujita, N e Badeshia, H. D. K. Modelling precipitation of Nb carbide in austenite: multicomponent diffusion, capilarity and coarsening. Materials Science and Technology. 2001, Vol. 17, pp. 403-408.

45. Jones, S.J e Bhadeshia, H.K.D.H. Kinetics of the Simultaneous Decomposition of Austenite into Several Transformation Products. Acta Metallurgica. 1997, Vol. 45, 7, pp. 2911-2920.

46. Kundu, S e Bhadeshia. Crystallographic texture and intervening transformations. Scripta Materialia. 2007, Vol. 57, pp. 869-872.

47. Schneider, A e Inden, G. Simulation of the kinectis of precipitation reactionds in ferritic steels. Acta Materialia. 2005, Vol. 53, pp. 519-531.

48. Yamada, K, et al. Effect of heat treatment on precipitation kinectis in high- $\mathrm{Cr}$ ferritic steels. ISIJ. 2002, Vol. 42, 7, pp. 779-784.

49. Wagner, C. Thermodynamics of Alloys. London, England: Adison-Wesley Publishing Co., 1952.

50. Darken, L. S. Thermodynamics of binary metallic solutions. Trans Metall. Soc. AIME. 1967, Vol. 237, pp. 80-89.

51. - Thermodynamics of ternary metallic solutions. Trans Metall. Soc. AIME. 1967, Vol. 237, pp. 90-96.

52. Saunders, N e Miodownik, A. P. CALPHAD: Calculation of Phase Diagrams, $A$ Comprehensive Guide. Oxford - UK: Pergamon Materials Series, 1998. 0-0080241296.

53. Farina, A.B. Aplicações da modelagem termodinâmica - Utilização, desenvolvimento e otimização de bancos de dados termodinâmicos. Departamento de Enegnharia Metalurgica e de Materiais, Escola Politécnica da USP. São Paulo : s.n., 2007. p. 282, Trabalho de Formatura.

54. Hillert, M. Phase Equilibria, Phase Diagram and Phase Tranformation - Their Thermodynamic Basis. s.I. : Cambridge University Press,, 1998.

55. Hillert, M. Janson, B. Sundman, B. Agren, J. A two-sublattice model for solutions with different tendency for ionization. Metall. Trans. A. 1985, Vol. 16A, pp. 261-266.

56. Sundman, Bo. Application of Dynamic Memory Management in Fortran. Report Series D. Div. of Physical Metallurgy - KTH, Stockholm, 1981, Vol. N29, Jan. 
57. - Application of Computer Techniques on the Treatment of the Thermodynamics of Alloys. PhD Thesis. Stockholm, Sweden: Div. Physical Metallurgy - KTH, 1981.

58. TCFE2, Banco de dados termodinâmicos. s.l. : ThermoCalc, 2000.

59. Estudo da Transformação Massiva Delta-Gama em aços Inoxidáveis. Farina, A. B, et al. [ed.] Laboratório de Fenômenos de Superfícies - EPUSP. São Paulo: Laboratório de Fenômenos de Superfícies - EPUSP, 2006. Anais do VII Encontro de Iniciação Científica do Laboratório de Fenômenos de Superfícies. pp. 1-5.

60. The behaviour of delta ferrite during quenching in an industrial ferritic stainless steel containing $11 \% \mathrm{Cr}$. Chéhab, Bréchet, Y, et al. [ed.] Metals and Materials Society) TMS (The Mineral. s.I. : TMS (The Mineral, Metals and Materials Society), 2005.

61. Ferro, R, Cacciamani, G e Borzone, G. Remarks about data reliability in experimental and computational alloy design. Intermetallics. 2003, Vol. 11, pp. 10811094.

62. Van der Ven, A. e Delaey, L. Models for precipitate growth during the $g->a+g$ transformation in Fe-C and Fe-C-M alloys. Progress in Mat. Sci. 1996, Vol. 40, pp. 181-264. 